\title{
Verification Test Report for CFAST 3.1.6 (U)
}

\author{
March 2002
}

D. A. Coutts

A. R. Martin

UNCLASSIFIED

DOES NOT CONTAIN UNCLASSIFIED CONTROLLED NUCLEAR INFORMATION

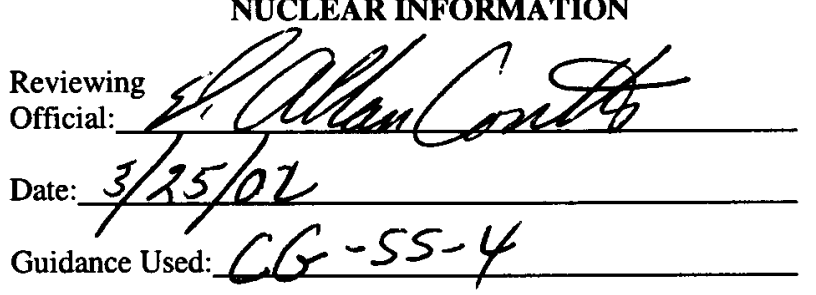

Westinghouse Safety Management Solutions LLC 1993 South Centennial Avenue, SE Aiken, SC 29804 
WSRC-TR-2001-00405

This page intentionally blank. 
WSRC-TR-2001-00405

Key words: CFAST

FAST

Verification

\title{
Verification Test Report for CFAST 3.1.6 (U)
}

March, 2002

D. A. Coutts

\author{
A. R. Martin
}


This document was prepared in conjunction with work accomplished under Contract No. DEAC09-96SR18500 with the U.S. Department of Energy.

\section{DISCLAIMER}

This report was prepared as an account of work sponsored by an agency of the United States Government. Neither the United States Government nor any agency thereof, nor any of their employees, makes any warranty, express or implied, or assumes any legal liability or responsibility for the accuracy, completeness, or usefulness of any information, apparatus, product or process disclosed, or represents that its use would not infringe privately owned rights. Reference herein to any specific commercial product, process or service by trade name, trademark, manufacturer, or otherwise does not necessarily constitute or imply its endorsement, recommendation, or favoring by the United States Government or any agency thereof. The views and opinions of authors expressed herein do not necessarily state or reflect those of the United States Government or any agency thereof.

This report has been reproduced directly from the best available copy.

Available for sale to the public, in paper, from: U.S. Department of Commerce, National Technical Information Service, 5285 Port Royal Road, Springfield, VA 22161

phone: (800) 553-6847

fax: (703) 605-6900

email: orders@ntis.fedworld.gov

online ordering: http://www.ntis.gov/support/index.html

Available electronically at http://www.osti.gov/bridge

Available for a processing fee to U.S. Department of Energy and its contractors, in paper, from: U.S. Department of Energy, Office of Scientific and Technical Information, P.O. Box 62, Oak Ridge, TN 37831-0062

phone: (865)576-8401

fax: (865)576-5728

email: reports@adonis.osti.gov 
Document: WSRC-TR-2001-00405

Title:

Verification Test Report for CFAST 3.1.6 (U)

Date: $\quad$ March, 2002

Author: $\quad$ D. A. Coutts, A. R. Martin

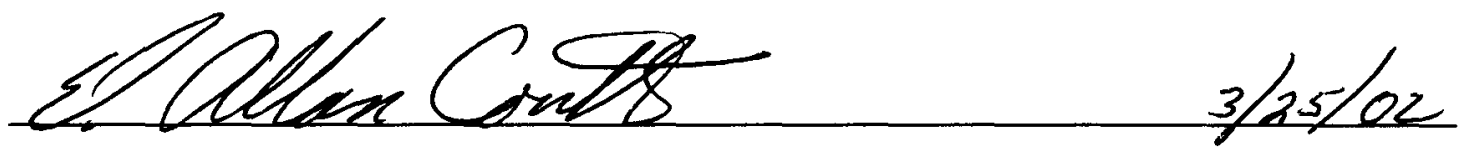

D. A. Coutts, Member

Date

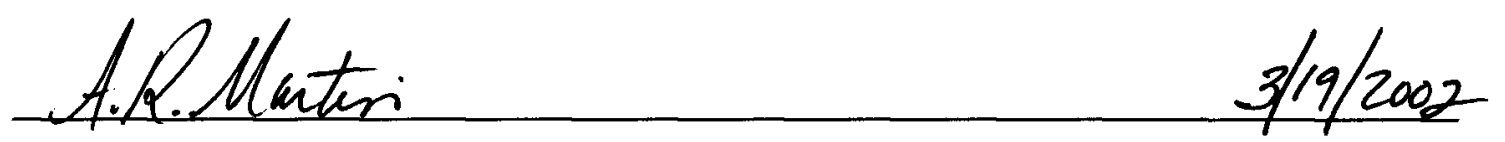

A. R. Martin, Member

Date

Approvals:
Kun. $0 \%$ h
$3 / 25 / 02$

K. O'Kula, Technical Reviewer

Date

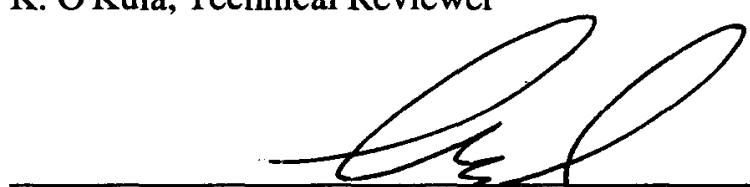

F. R. McCoy, Principal

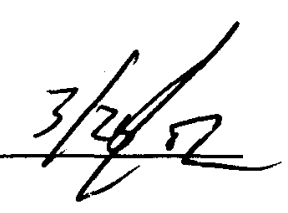

Date 
WSRC-TR-2001-00405

This page intentionally blank. 


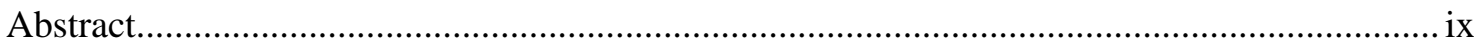

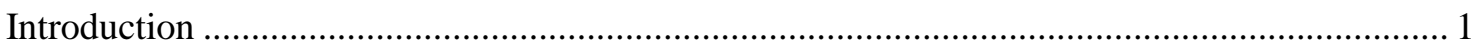

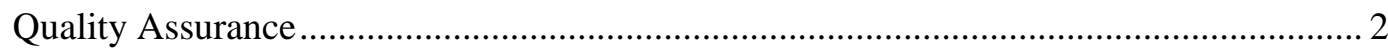

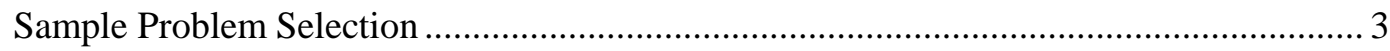

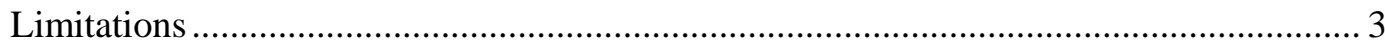

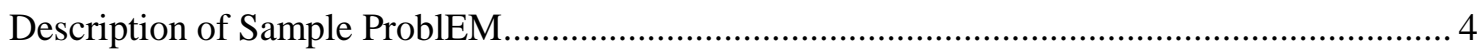

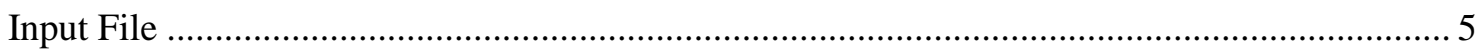

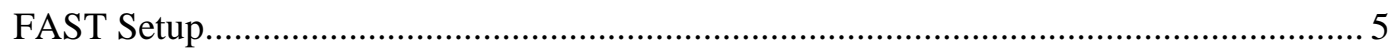

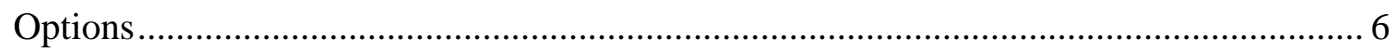

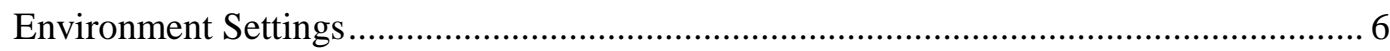

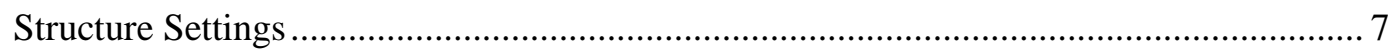

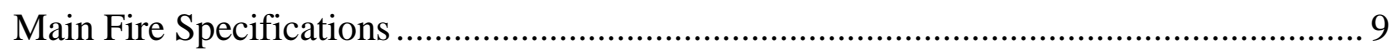

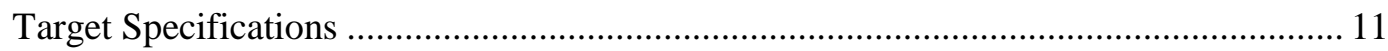

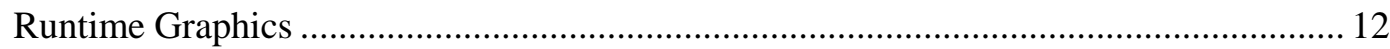

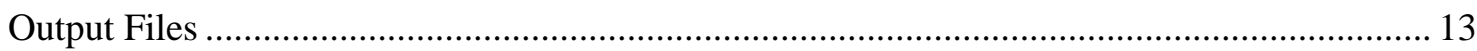

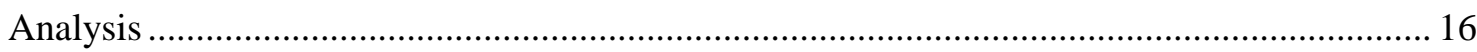

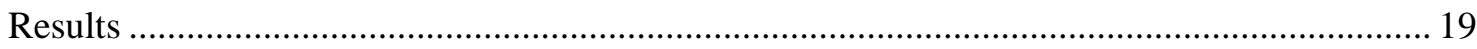

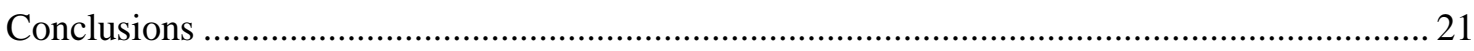

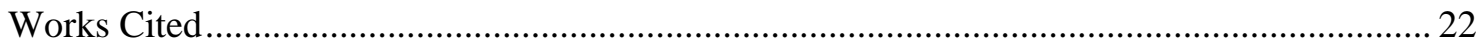

LIST OF TABLES $\quad$ Page

Table 1 -- FAST Capabilities and priority for their evaluation .................................................. 3

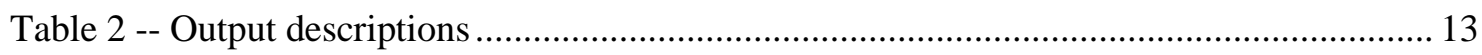

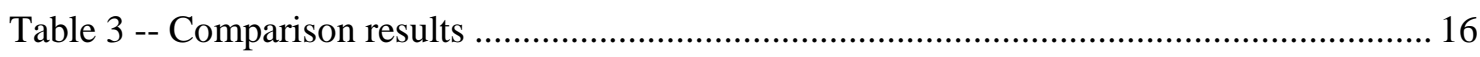

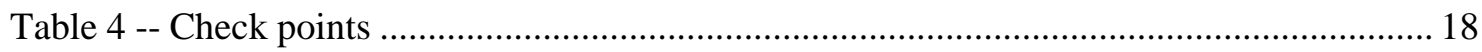

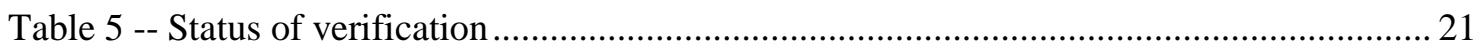

APPENDICES $\quad$ Page

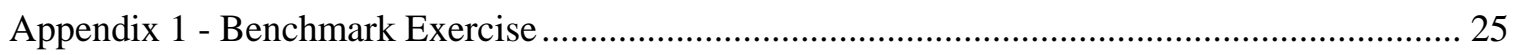

Appendix 2 - Input Data File (CTFIBASE.DAT) As Provided By Dr. Dey, NIST/NRC ............. 43

Appendix 3 - Input Data File (BASECASE.DAT) as Recreated for Verification Effort .............. 47

Appendix 4 - Results (CTFIBASE.CSV) as Provided by Dr. Dey............................................... 49

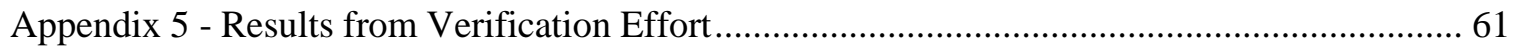

Appendix 6 - LITE.LST Report for Verification Effort …......................................................... 73

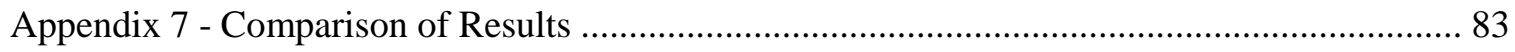

Appendix 8 - Comparison of Parameters with Significant Differences ....................................... 89 
WSRC-TR-2001-00405

This page intentionally blank. 
WSRC-TR-2001-00405

\begin{abstract}
Fire is a significant hazard in most facilities that handle radioactive materials. The severity of fire varies with room arrangement, combustible loading, ventilation and protective system response. The complexity of even simple situations can be unwieldy to solve by hand calculations. Thus, computer simulation of the fire severity has become an important tool in characterizing fire risk. The Savannah River Site (SRS), a Department of Energy facility, has been using the Consolidated Model of Fire Growth and Smoke Transport (CFAST) software to complete such deterministic evaluations to better characterize the nuclear facility fire severity.

To fully utilize CFAST at SRS it is necessary to demonstrate that CFAST produces valid analytic solutions over its range of use. This report describes the primary verification exercise that is required to establish that CFAST, and its user interface program FAST, produce valid analytic solutions. This verification exercise may be used to check the functionality of FAST and as a training tool to familiarize users with the software. In addition, the report consolidates the lessons learned by the SRS staff in using FAST and CFAST as fire modeling tools.
\end{abstract}


WSRC-TR-2001-00405

This page intentionally blank. 


\section{INTRODUCTION}

An uncontrolled fire in a nuclear facility can be a very energetic event. Severe smoke, excessive temperatures, and large thermal gradients are common. Such fires can readily breach containment barriers (glove box, ventilation ductwork and the building envelope) and, because of the significant thermal gradients, readily disperse radioactive material. Thus, uncontrolled fire can be a dominant risk in many nuclear facilities. This report presents the results of a software verification effort that was conducted for Consolidated Model of Fire Growth and Smoke Transport (CFAST) Version 3.1.6 [1] and its companion user interface program FAST [2].

The report accomplishes the following objectives:

- Documents an initial verification problem

- Consolidates user information to support SRS fire modeling work

- Establishes a consistent approach that can be used for verifying most fire models in use at SRS.

The report is separated into four major topics: Sample Problem Description, Input File, Output files and Analysis. A synopsis of the individual report sections is presented below.

Introduction. An overview of the information to be presented in the report.

Sample Problem Description. A general discussion of the sample problem that was selected for the verification effort.

Input File. A detailed description of the input file (i.e., input deck) that was constructed to execute the sample problem in FAST.

Output Files. An explanation of what results can be obtained from FAST by discussion of the sample problem output files.

Analysis. A comparison between a known solution for the verification problem and the solution as conducted by WSMS personnel.

Results. A discussion of the findings from the comparison.

Conclusions. A summary of the overall report. 
Works Cited. A list of references cited in the report.

Appendix 1 - Benchmark Exercise

Appendix 2 - Input Data File (CTFIBASE.DAT) As Provided By Dr. Dey, NIST/NRC

Appendix 3 - Input Data File (BASECASE.DAT) as Recreated for Verification Effort

Appendix 4 - Results (CTFIBASE.CSV) as Provided by Dr. Dey

Appendix 5 - Results from Verification Effort

Appendix 6 - LITE.LST Report for Verification Effort

Appendix 7 - Comparison of Results

Appendix 8 - Comparison of Parameters with Significant Differences

CFAST and FAST documentation consists of various reports that address multiple aspects of the code primarily in the form of NIST technical reports. Documentation includes:

- NIST Technical Note 1299, "CFAST, the Consolidated Model of Fire Growth and Smoke Transport" [1].

- $\quad$ NIST Special Publication 921, “A User’s Guide for FAST: Engineering Tools for Estimating Fire Growth and Smoke Transport" [2].

- $\quad$ NIST Technical Note 1431, “A Technical Reference for CFAST: An Engineering Tool for Estimating Fire and Smoke Transport”[3].

- NISTIR 5486-1, “Technical Reference Guide for FPEtool Version 3.2” [4].

- NBSIR 85-3223, "Data Sources for Parameters Used in Predictive Modeling of Fire Growth and Smoke Spread" [5].

These documents are available from the NIST web site http://fast.nist.gov.

\section{Quality Assurance}

To fully utilize CFAST at SRS it is necessary to prepare software quality assurance documentation as described in Westinghouse Savannah River Company (WSRC) Procedure Manual 1Q, Quality Assurance Manual, QAP 20-1, "Software Quality Assurance"[6] and Westinghouse Safety Management Solutions (WSMS) Procedure Manual 1Q, WSMS Quality Assurance Manual, Procedure 4-4, Revision 1, "Software Quality Assurance" [7]. This report describes the development of a verification problem and the demonstration that CFAST software produces verifiable results. This is considered to fulfil the verification effort for the software features listed in Table 1 below as established by the software development plan described in WSRC-RP-2000-00802 [8]. The version selected for this effort is CFAST 3.1.6 which is available from the NIST web site http://fast.nist.gov. To ensure configuration control, as required by WSRC 1Q, Quality Assurance Manual, QAP 20-1 [6] and WSMS 1Q, WSMS Quality

Assurance Manual, Procedure 4-4 [7], a version of the software is available from the WSMS 
server. This version is maintained by the Emergency and Fire Technical Services group on llexoduslwrkgrouplFIRE MODELS Databases.

\section{Sample Problem Selection}

Most software verification efforts consist of running sample problems, which are provided by the software author, to ensure that results are consistent with a known solution. While FAST is provided with sample input files, which can be used to demonstrate the program is functional, there are no documented results for these sample problems. Thus, there is nothing to allow the user to judge whether the software is producing valid results.

To overcome this impediment the first scenario from the recently completed benchmark exercise from the International Collaborative Project to Evaluate Fire Models for Nuclear Power Plant Applications [9] will be adopted as the "vendor supplied" sample problem. This problem provides a relatively simple baseline that can easily be replicated for verification of initial installation of the FAST code. Selection of this problem also provides a verifiable baseline that can be compared to other user results.

\section{Limitations}

The sample problem models a relatively small fire in a large room with a closed door. The target, which is evaluated as part of the problem, is a cable. The problem produces predictions of room temperature, ventilation through a narrow gap, oxygen consumption and target heat flux. The sample problem does not address oxygen limited fires or post-flashover fires. Such scenarios will require separate problems and could be accomplished by the complete development of the benchmark scenarios (both the natural and forced convection parts), which will address most of the top 10 desired features that need to be verified. These features are presented in Table 1 [10]. The sample problem chosen will address priorities 1, 2, 5, 7, 8 and 9. Items 6 and 10 are addressed in references 11 and 12, respectively. Items 3 and 4 are not addressed at this time.

Table 1 -- FAST Capabilities and priority for their evaluation

\begin{tabular}{l|c|c}
\hline \multicolumn{1}{c|}{ Parameter } & $\begin{array}{c}\text { Importance in reducing release } \\
\text { estimate over-conservatisms }\end{array}$ & $\begin{array}{c}\text { Priority for } \\
\text { validation }\end{array}$ \\
\hline Upper layer temperature & High & 1 \\
Horizontal opening ventilation & High & 2 \\
Fire curve database & High & 3 \\
Vertical opening ventilation & High & 4 \\
Lower layer temperature & High & 5 \\
Thermophysical data base & High & 6 \\
Oxygen content & High & 7 \\
Target temperature & Medium & 8 \\
Target heat flux & Medium & 9 \\
Fans (forced convection) & Medium & 10 \\
\hline
\end{tabular}




\section{DESCRIPTION OF SAMPLE PROBLEM}

This section provides an overview of the sample problem to be used in the verification effort. Items that are presented include the sample problem source and key problem details. All of the scenario specifics are described in Appendix 1.

The sample problem was taken from the International Collaborative Project to Evaluate Fire Models for Nuclear Power Plant Applications [9]. This project is a major non-proprietary fire modeling validation effort organized by the Nuclear Regulatory Commission (NRC) and the National Institute of Standards and Technology (NIST). This multi-national project is intended to share the knowledge and resources of various participating organizations to evaluate and improve the state of the art of fire models for use in nuclear power plant fire safety and fire hazard analyses. The group has completed one benchmark exercise.

The scenario described as Part I - Base Case in Appendix 1 is used as the sample problem. This scenario evaluates the effect of a trash fire on an isolated electric cable serving as a target. The scenario is limited to a single room, which is $15.2 \mathrm{~m}$ deep by $9.1 \mathrm{~m}$ wide and $4.6 \mathrm{~m}$ high. The room is provided with a closed door leading outside. The target is a single power cable with a diameter of $50 \mathrm{~mm}$ located at the bottom left corner of a cable tray. The cable tray is $0.6 \mathrm{~m}$ wide. The left edge of the cable is located $7.6 \mathrm{~m}$ from the left corner of the room and runs the entire depth of the room at a height of $2.275 \mathrm{~m}$ above the floor. The distance between the midpoints of the trash bag and the tray is $2.2 \mathrm{~m}$.

The input parameters, which are presented in the Benchmark Exercise included as Appendix 1, were provided as a FAST input file (CTFIBASE.DAT) by Dr. Monideep Dey, NIST/NRC. This FAST input file is included as Appendix 2. The input data file is reconstructed for this verification effort (BASECASE.DAT) and is included as Appendix 3. The details of the input file are discussed in the next section. 


\section{INPUT FILE}

This section describes the details of the input files in Appendix 2and Appendix 3. Appendix 2 contains the sample input file as provided by NIST/NRC, which is maintained for comparison to the input files from this verification effort. Appendix 3 contains the input file as prepared for this verification effort. In addition to discussing the details of the input files, this section presents a summary of how FAST forms the input file and how the input file can be modified by the user.

\section{FAST Setup}

When installing FAST on a WSRC or WSMS computer, the files should be taken from the Fire Model folder located on Ilexodus wrkgrouplFIRE MODELS\Databases. This path is commonly referred to as the $\mathrm{W}$-drive. The files should be written into a folder on the computer hard drive. Because the path will need to be typed repeatedly when input information is provided for files, it is recommended that the folder be contained in the " $\mathrm{C}$ " directory, rather than a subdirectory. For this effort, the files were copied to "C: $\backslash \mathrm{A}$ ". In addition to copying the file "setupf.exe" to this folder, the user should copy the most recent of the following files: WSMSTHxx.DF, and WSMSTHxx.NDX (currently WSMSTH03.DF, and WSMSTH03.NDX). These latter two files provide the verified material properties. They are intended to be used instead of the default thermal data base files provided with the FAST download (THERMAL.DF and THERMAL.NDX). See THERMF keyword under Options below.

After the three files are installed in the "FAST" folder, the file "setupf.exe" should be run from the "start" button on the bottom left of the computer screen. If necessary use the browse option under the run command. Follow the instructions on the screen as the program installs.

To run a FAST simulation, open FAST by running the executable file installed in the "FAST" folder. This file is titled "fast.exe". In building an input file, using the FAST interface will automatically generate the input deck (*.DAT file). For the sample problem presented, the user will need to provide the following:

- Simulation time and spreadsheet output

- Ambient conditions

- Compartment geometry

- Connections for horizontal flow

- Main fire specifications 
The discussion below provides details on specifying the parameters for the sample problem by presenting a line-by-line explanation of the input file included as Appendix 3. Reference 2, Section 2, provides additional detailed instruction for creating input data for FAST and provides a visual representation of the fire scenario overview window as it appears in FAST. Some variations were identified between the FAST software and the documentation for the software (i.e., Reference 2). The relevant variations identified in the development of this report are noted in the discussion below.

Note: As an alternative to building the input file using the FAST user interface, input files can be built or edited using WordPad. For multiple scenarios with minimal variation between the scenarios, editing in WordPad is the preferable approach. When editing the data file using WordPad, save it as a text file (*.DAT).

\section{Options}

A new installation of the FAST software displays measurements in standard SI units. Users can customize the display measurement units by selecting Options from the desktop menu then selecting User Specified Units. For this effort, the user specified units are left in SI units.

The THRMF keyword in the input file (Appendix 3) gives the location and name of the thermal database. The thermal database specifies the thermophysical properties of the enclosing surfaces and targets by specifying the thermal conductivity, specific heat, emissivity, density, and thickness of specific materials that are then identified as enclosing surfaces or targets in the structure settings.

THRMF C: \A\WSMSTH02.DF

The default thermal database file as provided by NIST is initially THERMAL.DF (not THERMAL.TPF or THERMAL.DAT as identified in reference 2, Section A.6). An alternate thermal database file can be entered in the configuration file, used for the current application only or the default thermal database file can be changed if desired. See Section 6.1 of Reference 2 for details. Materials can also be added to the thermal database file (THERMAL.DF) or an alternate database can be created. See Sections 2.4.3 and 2.4.4 of Reference 2 for details. For this effort and subsequent WSMS work, an alternate thermal database has been created, WSMSTH02.DF [11]. This approach was used to ensure that the physical property information in the database was traceable to a source document. To specify an alternate thermal database, select the filename icon in the environment section of the overview window. Then specify the path and filename for the database.

\section{Environment Settings}

VERSN specifies the version of the CFAST model for which the input data file is prepared and an optional user defined title for the file. When using the FAST interface, the version number is automatically assigned for the corresponding CFAST version.

VERSN 3PART 1 - BASE CASE

TIMES, in units of seconds, are the simulation time, print interval, history interval and display interval followed by the copy count.

$\begin{array}{llllll}\text { TIMES } & 600 & 10 & 10 & 10 & 0\end{array}$


The simulation time is a required input that has a maximum value of 86400 seconds. The print interval is the time interval between each printing of the output values. If omitted or less than or equal to zero, no printing of the output values will occur. The history interval is the time interval between each writing of the output to the history file. Documentation (reference 2, Section A.3) states that this value must be zero if no history file is to be used; however, non-specification of this parameter leads to no spreadsheet file output (i.e., even if no history output file is to be generated, the history file is still "used" to generate the spreadsheet output file). The display interval and copy count pertain to graphical display.

DUMPR gives the location and name of the history file output.

DUMPR C: \A \BASECASE.HI

History file is an optional input. If omitted, the file will not be generated. Note that, in order to obtain a history file, this parameter must be specified and the history interval must be set to a non-zero number. NOTE: As FAST is a DOS based program, the DOS naming convention applies.

ADUMP (or ADUMPF as identified in the documentation, Reference 2, Section A.3) gives the location and name of the spreadsheet (output) file and a specification of the type of output written to the spreadsheet file $(\mathrm{N}=$ Normal, $\mathrm{F}=$ Flow Field, $\mathrm{W}=$ Targets and Walls, $\mathrm{S}=$ Species, $\mathrm{P}=$ Wall Temperatures Profiles).

\section{ADUMP C: $\backslash A \backslash B A S E C A S E . T X T$ NES}

Spreadsheet file is an optional input. If omitted, the file will not be generated. Note that in order to obtain a spreadsheet file, this parameter must be specified and the history interval must be set to a non-zero number. Normal output is the default setting for type of output. It appears that the settings are usually not loaded from this line, thus whenever a new file is loaded the output is set to Normal. If it is desired to produce additional outputs they must be manually specified for each execution of the file. This is accomplished within FAST by selecting the filename icon in the environment section of the overview window. Next, select the Spreadsheet text button and then check the radio button(s) for the desired output. Click "OK", then specify the path and filename for the spreadsheet output file. Specifying a *.CSV or *.TXT. file creates a comma delimited file that can then be opened with a spreadsheet program (e.g., Excel). NOTE: As FAST is a DOS based program, the DOS naming convention applies.

TAMB and EAMB give first the internal and then the external ambient temperature $(\mathrm{K})$, ambient pressure $(\mathrm{Pa})$ and station elevation $(\mathrm{m})$ of the point at which the ambient temperature and pressure are measured.

$\begin{array}{lll}\text { TAMB } & 300.000 & 101300.0 .000000 \\ \text { EAMB } & 300.000 & 101300.0 .000000\end{array}$

Documentation (Reference 2, Section A.4) identifies the default ambient pressure as 101300 $\mathrm{Pa}$ and the default ambient temperature as $300 \mathrm{~K}$. However, it appears that the default ambient temperature is $293.15 \mathrm{~K}$.

\section{Structure Settings}

The size and location of every compartment in the structure MUST be described. The maximum number of compartments is 30 as indicated by the acceptable input range for this parameter 
within FAST (not 15 as specified in the documentation, Reference 2, Section A.5). In a structure with $n$ compartments, $n+1$ denotes outside. Present SRS models have been limited to 3 compartments.

$\mathrm{HI} / \mathrm{F}$ is the absolute height of the floor of the compartment with respect to the station elevation and is specified when defining each compartment. A structure with $n$ compartments will have $n$ data entries for this parameter.

\section{$\mathrm{HI} / \mathrm{F} \quad 0.000000$}

$\mathrm{HI} / \mathrm{F}$ is a required input. The default setting is zero. The acceptable input range for this parameter is 0 to $500 \mathrm{~m}$.

WIDTH, DEPTH and HEIGH give the width (from left wall to right wall [y]), depth (from rear wall forward $[\mathrm{x}]$ )and height $[\mathrm{z}]$ (in meters) of each compartment. See Illustration 1 below. A structure with $n$ compartments will have $n$ data entries for each of these parameters.

$\begin{array}{ll}\text { WIDTH } & 9.10000 \\ \text { DEPTH } & 15.2000 \\ \text { HEIGH } & 4.60000\end{array}$

WIDTH, DEPTH and HEIGH are required input. The default settings are 3.66, 2.44 and 2.44 $\mathrm{m}$, respectively. The acceptable input range for each of these dimensions is 0 to $500 \mathrm{~m}$.

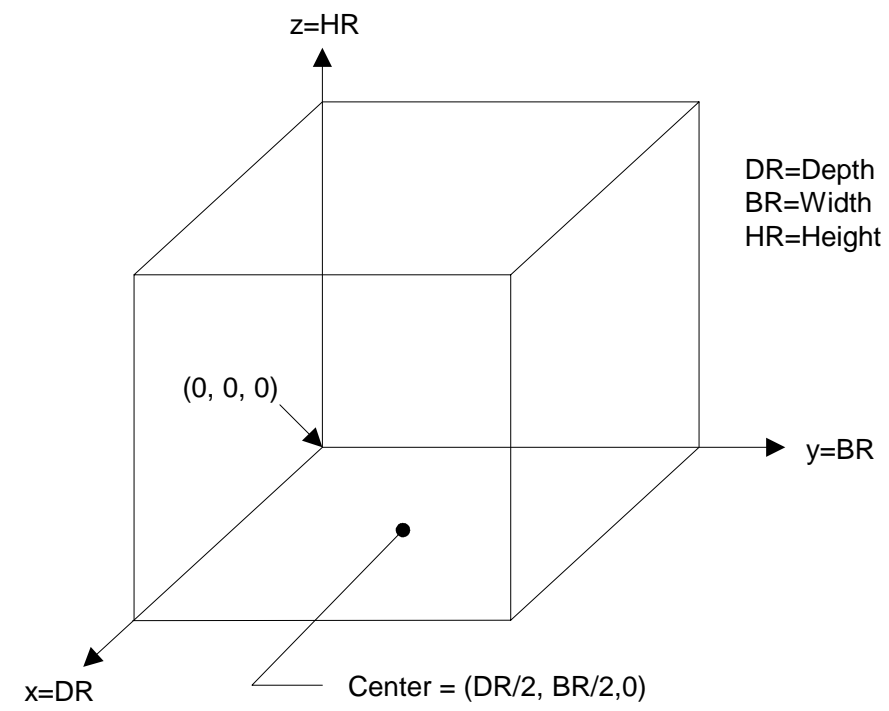

Illustration 1 - Orientation

CEILI, WALLS and FLOOR give the name of the material accessed from the thermal database file for the ceiling, walls and floor of each compartment. A structure with $n$ compartments will have $n$ data entries for each of these parameters.

CEILI CONCO03

WALLS CONCO03

FLOOR CONC003 
The default settings are gypsum for CEILI and WALLS and plywood for FLOOR. If the default thermal database file has been changed, these settings will need to be altered if the default materials are not listed in the default thermal database. Conduction in these surfaces can be turned on/off.

HVENT specifies natural flow horizontal vents. The first set of numbers are From Compartment, To Compartment, and the vent number (i.e., from Compartment 1 to Compartment 2 - Vent number 1 in the example). The next set of numbers define the opening width, soffit height and sill height $(\mathrm{m})$ of the vent followed by three optional parameters; the wind coefficient, the first compartment position and finally the second compartment position. See Reference 2, Section A.7 for additional information on these parameters.

\section{HVENT $1212.40000 \quad 0.00500000 \quad 0.000000 \quad 0.000000 \quad 0.000000$ 0.000000}

It is possible to define a total of four (4) horizontal flow connections between any pair of compartments. Location of the connection (i.e., sill height, soffit height) is given with respect to the floor of the "from" compartment.

CVENT is the opening/closing parameter for the natural flow horizontal vents. The first set of numbers are From Compartment, To Compartment, and the vent number (i.e., from Compartment 1 to Compartment 2 - Vent number 1 in the example). The next set of numbers are the opening/closing parameters corresponding to each point on the specified fire timeline. The default value of one corresponds to an open vent and a fractional value represents the ratio of the opening (i.e., 0.5 would specify a vent which is halfway open). The time increments corresponding to these opening/closing factors are specified in FTIME below.

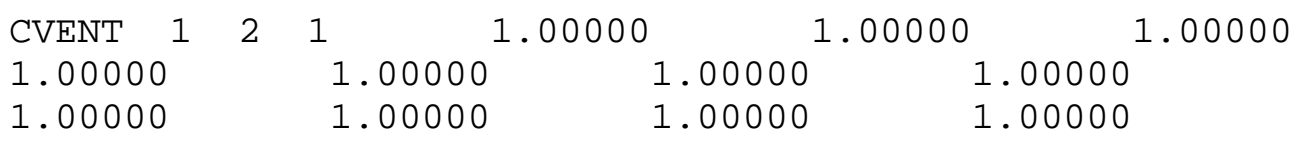

\section{Main Fire Specifications}

CHEMI gives parameters for kinetics as follows: the molar weight (molecular weight of the fuel vapor used for conversion to $\mathrm{ppm}$ ), relative humidity (\%), lower oxygen limit (\%), heat of combustion $(\mathrm{J} / \mathrm{kg})$, initial fuel temperature $(\mathrm{K})$, gaseous ignition temperature $(\mathrm{K})$, and radiative fraction.

$\begin{array}{llllll}\text { CHEMI } & 16.0000 & 50.0000 & 12.0000 & 2.41000 E+007 & 300.000\end{array}$
$493.150 \quad 0.300000$

The molar weight by default is 16.0. Relative humidity is specified within the environment settings and by default is 50\%. The lower oxygen limit is applicable only to Type 2 fires (see LFBT below) and by default is $10 \%$. The default heat of combustion, based on wood, is $1.95 \mathrm{E}+07 \mathrm{~J} / \mathrm{kg}$ (not 5.0E+07 as indicated in Reference 2, Section A.10). The defaults for initial fuel temperature, gaseous ignition temperature and radiative fraction are $293.15 \mathrm{~K}$, $493.15 \mathrm{~K}$ and 0.3 respectively. Section 2.2 .8 of Reference 2 states that if the gaseous ignition temperature is omitted, the default is arbitrarily set to the initial fuel temperature plus $200{ }^{\circ} \mathrm{C}$; however, it appears that it is set to the default initial fuel temperature $(293.15 \mathrm{~K})$ plus $200{ }^{\circ} \mathrm{C}$. 
LFBO is the compartment of fire origin (i.e., Compartment 1).

$\mathrm{LFBO} 1$

LFBT is the type of fire $(0=$ Off, $1=$ Unconstrained, $2=$ Constrained/Constrained with Flashover)

LFBT 2

CJET indicates for which surfaces convective heating will be determined. Setting selections are OFF, CEILING, WALLS and ALL.

CJET ALL

FPOS defines the position of the fire $(\mathrm{X}, \mathrm{Y}, \mathrm{Z})$. Note: -1.0 indicates position is centered on that axis.

FPOS $-1.00000 \quad 5.70000 \quad 0.000000$

For the fire position (see Illustration 1 on page 8 for orientation):

$\mathrm{X}$ Position is the position of the fire as a distance from the rear wall of the compartment $Y$ Position is the position of the fire as a distance from the left wall of the compartment $\mathrm{Z}$ Position is the height of the fire above the floor.

FTIME (s) gives the times for a defined heat release curve. Note that FTIME does not list the beginning time of 0.0 .

$\begin{array}{lcccc}\text { FTIME } & 60.0000 & 120.000 & 180.000 & 240.000 \\ 300.000 & 360.000 & 420.000 & 480.000 & \\ 540.000 & 600.000 & & \end{array}$

Initial entry of this curve specifies the mass loss rate, heat release rate, and if applicable the heat of combustion curve (see discussion below on over specifying fire curves). It also specifies the time step for various other parameters (CVENT, HCR, HCN, etc.). Note that after initial entry, any adjustment to this curve will affect all the time specified curves.

FMASS (kg/s) gives the mass loss rate corresponding to each point of the specified fire. Note that FMASS begins at 0.0 , which corresponds to a time of 0.0 .
FMASS
0.000000
0.00829876
0.0145228
0.0141079
0.00829876
0.00622407
0.00414938
0.00414938
0.00331950
0.00311203
0.00414938

FQDOT (W) gives the heat release rate corresponding to each point of the specified fire. Note that FQDOT begins at 0.0 , which corresponds to a time of 0.0 .

$\begin{array}{lrrrr}\text { FQDOT } & 0.000000 & 200000 . & 350000 . & 340000 . \\ 200000 . & 150000 . & 100000 . & 100000 . & \\ 80000.0 & 75000.0 & 100000 . & \end{array}$


Over specifying Fire Curves: Since the heat of combustion, heat release rate, and pyrolysis rate [mass loss rate] are related properties, the fire curve can be over specified. If each of the three parameters, heat of combustion from the fire specification window, heat release rate curve, and pyrolysis rate have been specified, the fire is over specified. The input editor accounts for this by using the two most recently entered to calculate the third parameter. This allows for two typical scenarios depending on whether the user desires to use a constant value heat of combustion or a heat of combustion curve. If the user desires to use a constant value heat of combustion, this value should first be entered in the fire specification window. Either the pyrolysis rate or heat release rate curve is then entered. If the pyrolysis rate curve is entered, the heat release rate is automatically calculated by multiplying each entry in the pyrolysis rate curve by the constant value heat of combustion. If the heat release rate is entered, the pyrolysis rate curve is calculated by dividing each entry of the heat release rate curve by the constant value heat of combustion. For the user desiring a heat of combustion curve rather than a constant value, the user should enter the heat release rate and pyrolysis rate curves separately. The model will calculate the appropriate heat of combustion curve prior to execution. One caution regarding this approach. If a user desiring a constant value heat of combustion saves the input file and returns later, the input editor views the heat release rate and pyrolysis rate curves as the last two properties entered. If the user then makes modifications to entries in one of the curves, the other curve will not be automatically calculated. The user must make a change to the heat of combustion in order to get the second curve recalculated. [2]

HCR is the hydrogen to carbon ratio $(\mathrm{kg} / \mathrm{kg})$ corresponding to each point of the specified fire timeline including the point corresponding to time equals zero in FTIME.

$\begin{array}{lcccc}\text { HCR } & 0.160000 & 0.160000 & 0.160000 & 0.160000 \\ 0.160000 & 0.160000 & 0.160000 & 0.160000 & \\ 0.160000 & 0.160000 & 0.160000 & \end{array}$

The default value for this ratio is 0.08 .

\section{Target Specifications}

The CFAST model can track and report calculations of the heat flux striking and the temperature of arbitrarily positioned and oriented targets. In order to specify targets, a compartment must be selected from the structure graphics list on the fire scenario overview window.

The TARGET is identified by specification of the compartment in which the target is located followed by the target position $(\mathrm{X}, \mathrm{Y}, \mathrm{Z})(\mathrm{m})$, the normal (direction) vector $(\mathrm{X}, \mathrm{Y}, \mathrm{Z})$, and the target material accessed from the thermal database file. Optional advanced settings include the solution method $($ STEADY $=$ Steady State, XPLICIT $=$ Explicit, MPLICIT $=$ Implicit $)$ and equation type (PDE or ODE). Note: -1.0 indicates position is centered on that axis.

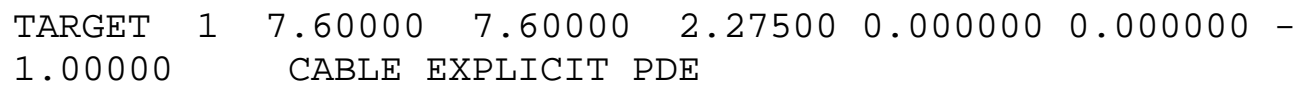

For the target position (see Illustration 1 on page 8 for orientation):

$\mathrm{X}$ Position is the position of the target as a distance from the rear wall of the compartment Y Position is the position of the target as a distance from the left wall of the compartment 
$\mathrm{Z}$ Position is the height of the target above the floor.

For the normal (direction) vector:

$\mathrm{X}, \mathrm{Y}$ and $\mathrm{Z}$ components of the unit normal vector pointing away from the target center. Provides description of the orientation of the target with respect to the back, left corner of the compartment. This should be a unit vector $\left(\mathrm{X}^{2}+\mathrm{Y}^{2}+\mathrm{Z}^{2}=1\right)$.

Targets in the same compartment are mutually exclusive. They are independently calculated and do not shield or cover each other. In the output files, targets are grouped by compartment number. Note: The program generates a floor target for each compartment. These floor targets will always be numbered after the manually added targets.

\section{Runtime Graphics}

The remaining entries pertain to runtime graphics and are not considered pertinent to the task at hand. See Reference 2, Section A.17 for more information on these parameters.

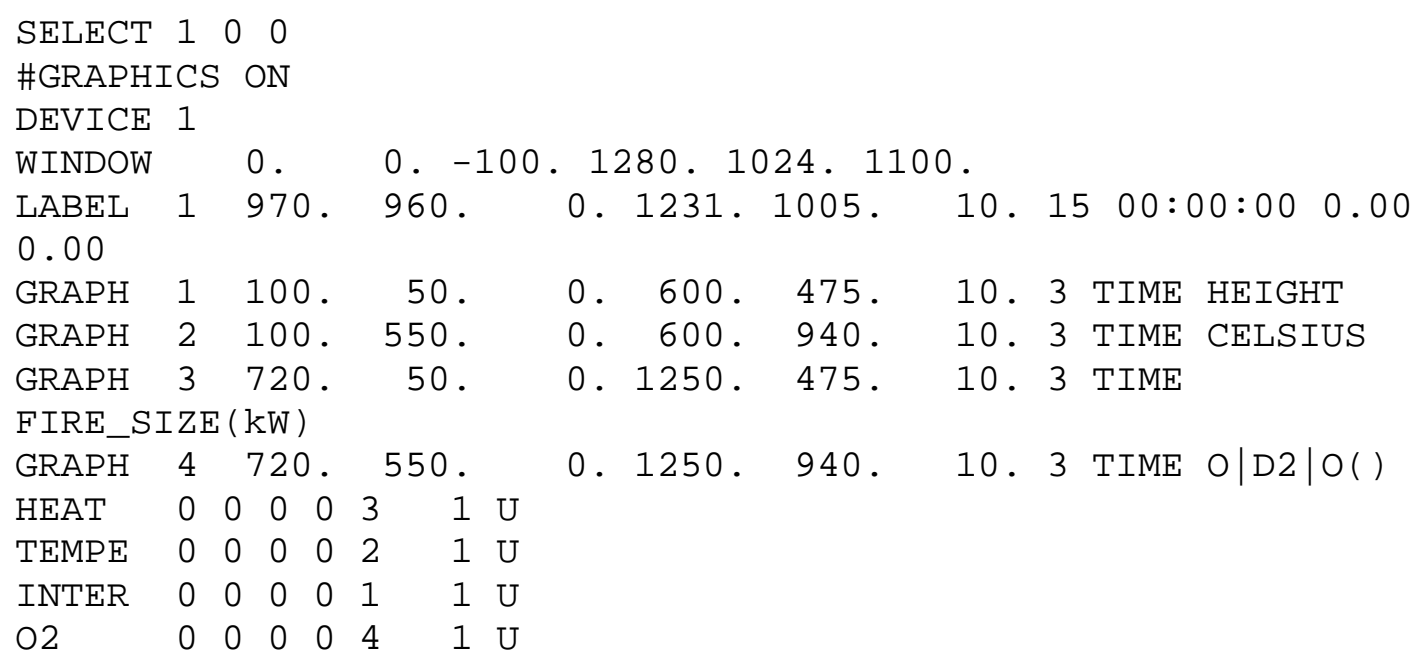




\section{OUTPUT FILES}

Results from execution of the sample problem were obtained from Dr. Dey, NIST/NRC. A spreadsheet output file and graphs of these results are included as Appendix 4. The spreadsheet output file and graphs of the results from execution of the sample problem for the verification effort are included as Appendix 5. A summary of the description and corresponding units for the output parameters are included in Table 2. These outputs were generated by choosing spreadsheet output selections of Normal, Flow Field and Species as described in the Environment Settings of the Input section of this report.

Table 2 -- Output descriptions

\begin{tabular}{|c|c|c|c|}
\hline Output Parameter & \begin{tabular}{|c|} 
Spreadsheet \\
Output \\
Selection \\
\end{tabular} & $\begin{array}{c}\text { Unit of Measure } \\
\text { (Ref. 1) }\end{array}$ & Description \\
\hline Upper Layer Temperature (1) & Normal & $\mathrm{K}$ & Upper layer temperature \\
\hline Lower Layer Temperature (1) & Normal & $\mathrm{K}$ & Lower layer temperature \\
\hline Layer Height (1) & Normal & $\mathrm{m}$ & Height above floor to bottom of upper layer \\
\hline Upper Layer Volume (1) & Normal & $\mathrm{m}^{3}$ & Upper layer volume \\
\hline Pressure (1) & Normal & $\mathrm{Pa}$ & Gauge pressure \\
\hline Ambient Target (1) & Normal & $\mathrm{W} / \mathrm{m}^{2}$ & Undefined \\
\hline Floor Target (1) & Normal & $\mathrm{W} / \mathrm{m}^{2}$ & Undefined \\
\hline Main Plume Flow & Normal & $\mathrm{kg} / \mathrm{s}$ & Plume mass flow rate for main fire \\
\hline Main Pyrolysis Rate & Normal & $\mathrm{kg} / \mathrm{s}$ & Fuel mass loss rate for main fire \\
\hline Main Fire Size & Normal & W & Heat release rate (HRR) \\
\hline Main Flame Height & Normal & $\mathrm{m}$ & Undefined \\
\hline Main Convection Size & Normal & $\mathrm{W}$ & Undefined \\
\hline Target Temperature (1) & Normal & $\mathrm{K}$ & Target surface temperature \\
\hline Target Flux (1) & Normal & $\mathrm{W} / \mathrm{m}^{2}$ & Incoming flux on target \\
\hline Target Fire Radiation (1) & Normal & of Target Flux (1) & Target Fire Radiation (1) \\
\hline Target Surface Radiation (1) & Normal & of Target Flux (1) & Target Surface Radiation (1) \\
\hline Target Gas Radiation (1) & Normal & of Target Flux (1) & Target Gas Radiation (1) \\
\hline Target Convection (1) & Normal & of Target Flux (1) & Target Convection (1) \\
\hline Target Temperature (2) & Normal & $\mathrm{K}$ & Undefined \\
\hline Target Flux (2) & Normal & $\mathrm{W} / \mathrm{m}^{2}$ & Undefined \\
\hline Target Fire Radiation (2) & Normal & of Target Flux (2) & Undefined \\
\hline Target Surface Radiation (2) & Normal & of Target Flux (2) & Undefined \\
\hline Target Gas Radiation (2) & Normal & of Target Flux (2) & Undefined \\
\hline Target Convection (2) & Normal & of Target Flux (2) & Undefined \\
\hline Upper $\mathrm{N}_{2}(1)$ & Species & $\%$ & mass concentration of nitrogen in upper layer \\
\hline Upper $\mathrm{O}_{2}(1)$ & Species & $\%$ & mass concentration of oxygen in upper layer \\
\hline
\end{tabular}


WSRC-TR-2001-00405

\begin{tabular}{|c|c|c|c|}
\hline Output Parameter & \begin{tabular}{|c|} 
Spreadsheet \\
Output \\
Selection \\
\end{tabular} & $\begin{array}{l}\text { Unit of Measure } \\
\text { (Ref. 1) }\end{array}$ & Description \\
\hline Upper $\mathrm{CO}_{2}(1)$ & Species & $\%$ & $\begin{array}{l}\text { mass concentration of carbon dioxide in } \\
\text { upper layer }\end{array}$ \\
\hline Upper CO (1) & Species & ppm & $\begin{array}{l}\text { mass concentration of carbon monoxide in } \\
\text { upper layer }\end{array}$ \\
\hline Upper HCN (1) & Species & ppm & $\begin{array}{l}\text { mass concentration of hydrogen cyanide in } \\
\text { upper layer }\end{array}$ \\
\hline Upper HCL (1) & Species & ppm & $\begin{array}{l}\text { mass concentration of hydrogen chloride in } \\
\text { upper layer }\end{array}$ \\
\hline Upper TUHC (1) & Species & $\%$ & $\begin{array}{l}\text { mass concentration of total unburned } \\
\text { hydrocarbons in upper layer }\end{array}$ \\
\hline Upper $\mathrm{H}_{2} \mathrm{O}(1)$ & Species & $\%$ & mass concentration of water in upper layer \\
\hline Upper OD (1) & Species & $\mathrm{m}^{-1}$ & mass concentration of soot in upper layer \\
\hline $\mathrm{HCl} c(1)^{1}$ & Species & $\mathrm{mg} / \mathrm{m}^{2}$ & Undefined \\
\hline $\mathrm{HCl} \mathrm{uw}(1)^{1}$ & Species & $\mathrm{mg} / \mathrm{m}^{2}$ & Undefined \\
\hline $\mathrm{HCl} \mathrm{lw}(1)^{1}$ & Species & $\mathrm{mg} / \mathrm{m}^{2}$ & Undefined \\
\hline $\mathrm{HCl} \mathrm{f}(1)^{1}$ & Species & $\mathrm{mg} / \mathrm{m}^{2}$ & Undefined \\
\hline Lower $\mathrm{N}_{2}(1)$ & Species & $\%$ & mass concentration of nitrogen in lower layer \\
\hline Lower $\mathrm{O}_{2}(1)$ & Species & $\%$ & mass concentration of oxygen in lower layer \\
\hline Lower $\mathrm{CO}_{2}(1)$ & Species & $\%$ & $\begin{array}{l}\text { mass concentration of carbon dioxide in } \\
\text { lower layer }\end{array}$ \\
\hline Lower CO (1) & Species & ppm & $\begin{array}{l}\text { mass concentration of carbon monoxide in } \\
\text { lower layer }\end{array}$ \\
\hline Lower HCN (1) & Species & ppm & $\begin{array}{l}\text { mass concentration of hydrogen cyanide in } \\
\text { lower layer }\end{array}$ \\
\hline Lower $\mathrm{HCl}(1)$ & Species & ppm & $\begin{array}{l}\text { mass concentration of hydrogen chloride in } \\
\text { lower layer }\end{array}$ \\
\hline Lower TUHC (1) & Species & $\%$ & $\begin{array}{l}\text { mass concentration of total unburned } \\
\text { hydrocarbons in lower layer }\end{array}$ \\
\hline Lower $\mathrm{H}_{2} \mathrm{O}(1)$ & Species & $\%$ & mass concentration of water in lower layer \\
\hline Lower OD (1) & Species & $\mathrm{m}^{-1}$ & mass concentration of soot in lower layer \\
\hline $\mathrm{HCl} \mathrm{c}(1)^{2}$ & Species & $\mathrm{mg} / \mathrm{m}^{2}$ & Undefined \\
\hline $\mathrm{HCl} \mathrm{uw}(1)^{2}$ & Species & $\mathrm{mg} / \mathrm{m}^{2}$ & Undefined \\
\hline $\mathrm{HCl} \mathrm{lw}(1)^{2}$ & Species & $\mathrm{mg} / \mathrm{m}^{2}$ & Undefined \\
\hline $\mathrm{HCl} \mathrm{f}(1)^{2}$ & Species & $\mathrm{mg} / \mathrm{m}^{2}$ & Undefined \\
\hline Upper Inflow 1-Outside (1) & Flow Field & $\mathrm{kg} / \mathrm{s}$ & mass flow rate into upper layer \\
\hline Upper Outflow 1-Outside (1) & Flow Field & $\mathrm{kg} / \mathrm{s}$ & mass flow rate out of upper layer \\
\hline Lower Inflow 1-Outside (1) & Flow Field & $\mathrm{kg} / \mathrm{s}$ & mass flow rate into lower layer \\
\hline Lower Outflow 1-Outside (1) & Flow Field & $\mathrm{kg} / \mathrm{s}$ & mass flow rate out of lower layer \\
\hline
\end{tabular}

With the exception of Targets, (1) denotes compartment number 1, (2) compartment number 2, etc.

For Targets, (1) denotes last target defined, etc. See Target Specifications for numbering convention of targets.

The outputs for targets; target fire radiation, target surface radiation, target gas radiation and target convection are given as a percentage of the (total) target flux for both Target (1) and Target (2). Target (1) is the cable and Target (2) is a preset target that is a point on the floor in the center of the room. Target (2) is not evaluated in this verification effort. Likewise, the output for Ambient Target (1) and Floor Target (1) are not evaluated at this time due to ambiguity regarding these specifications.

Additional output reports are available from FAST. One such report is automatically generated each time the data file is executed. This file is Lite.lst and is stored in the same file as the source code. The report contains an overview of the input parameters and settings as well as selected 
data for each time step specified in the history interval. The file should be renamed and saved if the information is to be retained as the program writes to the Lite.lst file each time a run is performed. The LITE.LST report generated for the verification effort is included as Appendix 6. Output reports can also be ran from DOS. "Report" requires a history file as input. At the DOS prompt enter:

C:Ifastlreport [location and name of history file $(* . H I)] /$ r:nnn [desired location and name of output file (*.TXT)]

where nnn is

$\begin{array}{lll}\mathrm{w} & \Rightarrow & \text { temperature profiles in the walls } \\ \mathrm{i} & \Rightarrow & \text { building configuration } \\ \mathrm{n} & \Rightarrow & \text { normal temperature/interface history } \\ \mathrm{f} & \Rightarrow & \text { flow fields } \\ \mathrm{s} & \Rightarrow & \text { species } \\ \mathrm{t} & \Rightarrow & \text { tenability estimates for each compartment } \\ \mathrm{p} & \mathrm{P} & \text { wall temperature profiles }\end{array}$




\begin{abstract}
ANALYSIS
A comparison of the Appendix 4 output (CTFIBASE.CSV) and the output from the verification effort (BASECASE.XLS) is performed using Excel. This comparison is a relative difference computation and is included as Appendix 7. Exact matches are identified as "OK". A value in a cell indicates a non-match. The relative difference calculated is the ratio of the difference between the output of each of the two efforts to the Appendix 4 output, rounded to four digits.

Comparison values that are less than $0.01 \%$ are considered acceptable. These differences are considered insignificant and can probably be attributed to differences in machine precision, round-off, settings within spreadsheet programs and uncertainty within the model due to incompletely understood physics and necessary numerical simplifications. For output parameters of interest, any comparison values greater than $0.01 \%$ are examined. Parameters that are addressed by this effort are identified in Table 3 below. Significant parameters, as presented in Table 1, not addressed by this effort are the fire curve database, vertical opening ventilation and fans (forced convection).
\end{abstract}

Table 3 -- Comparison results

\begin{tabular}{l|c|c|c}
\hline \multicolumn{1}{c|}{ Output Parameter } & $\begin{array}{c}\text { Unit of Measure } \\
\text { (Ref. 2) }\end{array}$ & $\begin{array}{c}\text { Difference } \\
>\mathbf{0 . 0 1 \%}\end{array}$ & Results \\
\hline Upper Layer Temperature (1) & $\mathrm{K}$ & No & Acceptable \\
Lower Layer Temperature (1) & $\mathrm{K}$ & No & Acceptable \\
Layer Height (1) & $\mathrm{m}$ & No & Acceptable \\
Upper Layer Volume (1) & $\mathrm{m}^{3}$ & No & Acceptable \\
Pressure (1) & $\mathrm{Pa}$ & Yes & Requires Evaluation \\
Ambient Target (1) & $\mathrm{W} / \mathrm{m}^{2}$ & Yes & Not Verified \\
Floor Target (1) & $\mathrm{W} / \mathrm{m}^{2}$ & Yes & Not Verified \\
Main Plume Flow & $\mathrm{kg} / \mathrm{s}$ & No & Acceptable \\
Main Pyrolysis Rate & $\mathrm{kg} / \mathrm{s}$ & No & Acceptable \\
Main Fire Size & $\mathrm{W}$ & No & Acceptable \\
Main Flame Height & $\mathrm{m}$ & No & Acceptable \\
Main Convection Size & $\mathrm{W}$ & No & Acceptable \\
Target Temperature (1) & $\mathrm{K} / \mathrm{m}^{2}$ & No & Acceptable \\
Target Flux (1) & No & Acceptable \\
Target Fire Radiation (1) & $\%$ of Target Flux (1) & No & Acceptable \\
Target Surface Radiation (1) & $\%$ of Target Flux (1) & No & Acceptable \\
Target Gas Radiation (1) & $\%$ of Target Flux (1) & No & Acceptable \\
Target Convection (1) & $\%$ of Target Flux (1) & Yes & Requires Evaluation \\
Target Temperature (2) & $\mathrm{K}$ & No & Not Verified \\
Target Flux (2) & $\mathrm{W} / \mathrm{m}^{2}$ & No & Not Verified \\
Target Fire Radiation (2) & $\%$ of Target Flux (2) & No & Not Verified \\
\hline
\end{tabular}


WSRC-TR-2001-00405

\begin{tabular}{|c|c|c|c|}
\hline Output Parameter & $\begin{array}{c}\text { Unit of Measure } \\
\text { (Ref. 2) }\end{array}$ & $\begin{array}{c}\text { Difference } \\
>0.01 \%\end{array}$ & Results \\
\hline Target Surface Radiation (2) & $\%$ of Target Flux (2) & No & Not Verified \\
\hline Target Gas Radiation (2) & $\%$ of Target Flux (2) & No & Not Verified \\
\hline Target Convection (2) & $\%$ of Target Flux (2) & Yes & Not Verified \\
\hline Upper $\mathrm{N}_{2}(1)$ & $\%$ & No & Not Verified \\
\hline Upper $\mathrm{O}_{2}(1)$ & $\%$ & No & Acceptable \\
\hline Upper $\mathrm{CO}_{2}(1)$ & $\%$ & No & Not Verified \\
\hline Upper CO (1) & $\mathrm{ppm}$ & No & Not Verified \\
\hline Upper HCN (1) & $\mathrm{ppm}$ & No & Not Verified \\
\hline Upper HCL (1) & ppm & No & Not Verified \\
\hline Upper TUHC (1) & $\%$ & No & Not Verified \\
\hline Upper $\mathrm{H}_{2} \mathrm{O}(1)$ & $\%$ & No & Not Verified \\
\hline Upper OD (1) & $\mathrm{m}^{-1}$ & No & Not Verified \\
\hline $\mathrm{HCl} c(1)^{1}$ & $\mathrm{mg} / \mathrm{m}^{2}$ & No & Not Verified \\
\hline $\mathrm{HCl} \mathrm{uw}(1)^{1}$ & $\mathrm{mg} / \mathrm{m}^{2}$ & No & Not Verified \\
\hline $\mathrm{HCl} \mathrm{lw}(1)^{1}$ & $\mathrm{mg} / \mathrm{m}^{2}$ & No & Not Verified \\
\hline $\mathrm{HCl} \mathrm{f}(1)^{1}$ & $\mathrm{mg} / \mathrm{m}^{2}$ & No & Not Verified \\
\hline Lower $\mathrm{N}_{2}(1)$ & $\%$ & No & Not Verified \\
\hline Lower $\mathrm{O}_{2}(1)$ & $\%$ & No & Acceptable \\
\hline Lower $\mathrm{CO}_{2}(1)$ & $\%$ & No & Not Verified \\
\hline Lower CO (1) & ppm & No & Not Verified \\
\hline Lower HCN (1) & $\mathrm{ppm}$ & No & Not Verified \\
\hline Lower $\mathrm{HCl}(1)$ & ppm & No & Not Verified \\
\hline Lower TUHC (1) & $\%$ & No & Not Verified \\
\hline Lower $\mathrm{H}_{2} \mathrm{O}(1)$ & $\%$ & No & Not Verified \\
\hline Lower OD (1) & $\mathrm{m}^{-1}$ & No & Not Verified \\
\hline $\mathrm{HCl} c(1)^{2}$ & $\mathrm{mg} / \mathrm{m}^{2}$ & No & Not Verified \\
\hline $\mathrm{HCl} \mathrm{uw}(1)^{2}$ & $\mathrm{mg} / \mathrm{m}^{2}$ & No & Not Verified \\
\hline $\mathrm{HCl} \mathrm{lw}(1)^{2}$ & $\mathrm{mg} / \mathrm{m}^{2}$ & No & Not Verified \\
\hline $\mathrm{HCl} f(1)^{2}$ & $\mathrm{mg} / \mathrm{m}^{2}$ & No & Not Verified \\
\hline Upper Inflow 1-Outside (1) & $\mathrm{kg} / \mathrm{s}$ & No & Acceptable \\
\hline Upper Outflow 1-Outside (1) & $\mathrm{kg} / \mathrm{s}$ & No & Acceptable \\
\hline Lower Inflow 1-Outside (1) & $\mathrm{kg} / \mathrm{s}$ & Yes & Requires Evaluation \\
\hline Lower Outflow 1-Outside (1) & $\mathrm{kg} / \mathrm{s}$ & Yes & Requires Evaluation \\
\hline
\end{tabular}

${ }^{1}$ Upper Layer Species [2]

${ }^{2}$ Lower Layer Species [2]

Those parameters identified as requiring evaluation in Table 3 were examined in more detail. Significant relative differences (>0.01\%) exist for Pressure (1), Target Convection (1), Lower Inflow 1-Outside (1), Lower Outflow 1-Outside (1). Each parameter was graphed as a function of time and a comparison between the output of the two efforts was performed. These graphs are included as Appendix 8. A graph of the deltas at each time-step for each parameter is also included in Appendix 8.

In addition to the comparison with the Appendix 4 output, an alternate analysis was conducted with a second WSMS computer. No variation was observed when compared with output from this effort. For the verified parameters, selected check points for output values consisting of minimum and maximum values with the corresponding time of occurrence, intercept times (where applicable) and output values at 150 seconds are listed below in Table 4 . 
Table 4 -- Check points

\begin{tabular}{|c|c|c|c|c|c|c|c|}
\hline \multicolumn{2}{|r|}{ Output } & \begin{tabular}{|c|} 
Maximum \\
Value
\end{tabular} & $\begin{array}{l}\text { Minimum } \\
\text { Value }\end{array}$ & $\begin{array}{c}t_{\max } \\
(s)\end{array}$ & $\begin{array}{c}\mathbf{t}_{\min } \\
(\mathbf{s})\end{array}$ & $\begin{array}{l}\mathbf{t}_{\text {int }} \\
(\mathbf{s})\end{array}$ & $t=150 \mathrm{~s}$ \\
\hline \multicolumn{8}{|c|}{ Normal Output } \\
\hline $\mathrm{A}$ & TIME & 590 & 0 & & & & 150 \\
\hline $\mathrm{B}$ & Upper Layer Temp (1) & 356.842 & 300 & 240 & 0 & & 345.248 \\
\hline $\mathrm{C}$ & Lower Layer Temp (1) & 301.967 & 300 & 150 & 0 & & 301.967 \\
\hline $\mathrm{D}$ & Layer Height (1) & 4.59954 & 0.384782 & 0 & 590 & & 1.55532 \\
\hline $\mathrm{E}$ & Upper Layer Volume (1) & 583.049 & 0.063627 & 590 & 0 & & 421.14 \\
\hline $\mathrm{F}$ & Pressure (1) & 2056.85 & -37.3101 & 150 & 370 & 305 & 2056.85 \\
\hline I & Main Plume Flow & 4.64977 & & 20 & & & 1.2837 \\
\hline $\mathrm{J}$ & Main Pyrolysis Rate & 0.0145228 & & 120 & & & 0.014315 \\
\hline $\mathrm{K}$ & Main Fire Size & 349975 & & 120 & & & 344971 \\
\hline $\mathrm{L}$ & Main Flame Height & 2.00934 & & 120 & & & 1.99389 \\
\hline $\mathrm{M}$ & Main Convec. Size & 244983 & & 120 & & & 241480 \\
\hline $\mathrm{N}$ & Target Temperature (1) & 322.202 & 300 & 420 & 0 & & 315.647 \\
\hline $\mathrm{O}$ & Target Flux (1) & 1256.28 & & 180 & & & 1240.22 \\
\hline $\mathrm{P}$ & Target Fire Rad. (1) & 54.9308 & & 90 & & & 35.5719 \\
\hline $\mathrm{Q}$ & Target Surface Rad. (1) & 83.0962 & & 10 & & & 17.2399 \\
\hline $\mathrm{R}$ & Target Gas Rad. (1) & 72.5473 & & 540 & & & 35.3368 \\
\hline $\mathrm{S}$ & Target Convec. (1) & 16.3427 & -1.85068 & 240 & 90 & 92 & 11.8514 \\
\hline \multicolumn{8}{|c|}{ Species Output } \\
\hline AA & Upper O2 (1) & 20.538 & 19.2299 & 0 & 590 & & 19.9373 \\
\hline $\mathrm{AN}$ & Lower O2 (1) & 20.538 & 20.4718 & $0 \& 20$ & 310 & & 20.5245 \\
\hline \multicolumn{8}{|c|}{ Flow Field Output } \\
\hline $\mathrm{AZ}$ & Upper Inflow 1-Outside (1) & & & & & & \\
\hline $\mathrm{BA}$ & Upper Outflow 1-Outside (1) & & & & & & 0 \\
\hline $\mathrm{BB}$ & Lower Inflow 1-Outside (1) & 0.0784142 & 0 & 370 & $0-300$ & & 0 \\
\hline $\mathrm{BC}$ & Lower Outflow 1-Outside (1) & 0.586178 & 0 & 150 & $310-590$ & & 0.586178 \\
\hline
\end{tabular}




\begin{abstract}
RESULTS
From the comparison between the Appendix 4 output (CTFIBASE.CSV) and the output from this verification effort (BASECASE.XLS), most of the parameters evaluated have a relative difference of less than 0.01 percent, which is considered acceptable. As discussed previously, the parameters Ambient Target (1), Floor Target (1) and Target (2) are not verified due to ambiguity regarding these specifications. Furthermore, the parameters for $\mathrm{N}_{2}, \mathrm{CO}_{2}, \mathrm{CO}, \mathrm{HCN}, \mathrm{HCl}$, TUHC, and OD are not verified as the production of these species are held to zero and thus not considered in the simulation. Some variation does exist for the following parameters discussed individually below.
\end{abstract}

Pressure (1)

The pressure output is the gage pressure and is calculated in CFAST as the difference between absolute pressure and atmospheric pressure. As CFAST is calculating this value based on an atmospheric pressure of $101300 \mathrm{~Pa}$ and output values are considerably smaller than this value, variation can be attributed to differences due to round-off.

A graph comparing the pressure output of each effort does not reveal any significant difference between the two (See Appendix 8, Figure 1). The relative difference as calculated for the comparison in Appendix 7 shows that a significant relative difference $(>0.01 \%)$ begins to occur at 230 seconds and essentially stays above this level for the remainder of the simulation. As indicated by a graph of the delta for the two output files (Appendix 8, Figure 2), the largest differences occur during the period between 120 and 250 seconds. For most of this time period, the pressure is relatively large (around $1000 \mathrm{~Pa}$ ) hence the delta is insignificant. However, as the pressure begins to drop and becomes relatively small (220 Pa at $250 \mathrm{~s})$, the delta becomes more significant.

\title{
Target Convection (1)
}

Target convection output is calculated with CFAST as a percentage of the total target flux. A graph comparing the target convection output of each effort does not reveal any significant difference between the two (See Appendix 8, Figure 3). The relative difference as calculated for the comparison in Appendix 7 shows that a significant relative difference $(>0.01 \%)$ occurs at 490 seconds and 570 seconds. This difference is only about $0.02 \%$. As indicated by a graph of the delta for the two output files, the largest difference is 2.5E-03 (See Appendix 8, Figure 4). As the target convection is calculated as a percentage of the total target flux, and the target convection at these times is relatively small (about ten percent of the total flux), this difference becomes proportionally large. Hence the significant difference for target convection can probably be attributed to rounding effects in calculating the percentage within CFAST. 


\section{Lower Inflow 1-Outside (1)}

Lower Inflow 1-Outside (1) is the airflow (kg/s) from outside into the room lower layer. A graph comparing the lower inflow results of each effort does not reveal any significant difference between the two (See Appendix 8, Figure 5). The relative difference as calculated for the comparison in Appendix 7 shows that a significant relative difference $(>0.01 \%)$ begins to occur at 310 seconds when the airflow changes from outflow to inflow because the fire is no longer large enough to pressurize the room. Prior to this point, the inflow is zero as outflow occurs. The largest difference was 4.83E-05 (See Appendix 8, Figure 6 for a graph of the delta for the two output files). The values calculated are very small (on the order of $10^{-2}$ to $10^{-3}$ ), thus small differences can produce high percentage errors because of division by a value close to zero.

\section{$\underline{\text { Lower Outflow 1-Outside (1) }}$}

Lower Outflow 1-Outside (1) is the airflow $(\mathrm{kg} / \mathrm{s})$ from the room lower layer to outside. A graph comparing the lower outflow results of each effort does not reveal any significant difference between the two (See Appendix 8, Figure 7). The relative difference as calculated for the comparison in Appendix 7 shows that a significant relative difference $(>0.01 \%)$ occurs only at 290 and 300 seconds when the airflow changes from outflow to inflow because the fire is no longer large enough to pressurize the room. The largest difference is 2.9E-05 (See Appendix 8, Figure 8 for a graph of the delta for the two output files). As with the inflow, the values calculated are small and the relative difference becomes more significant due to division by a near zero number. 


\section{CONCLUSIONS}

The parameters listed in Table 5 are verified for a specific sample problem involving a fire that did not approach flashover conditions. In most cases, the normalized (percentage) difference between the test case and the base case is below 0.01 percent. The largest difference was 1.56 percent, which was for the room gage pressure. This large normalized error, and most of the other large normalized errors, is due to the fact that the calculated parameter was so small (i.e., division by a value close to zero). In terms of the applications for which the FAST model will be used, such errors are considered negligible.

In addition to the verification effort an installation check routine is recommended. This routine should be used whenever FAST is initially installed on a computer and prior to any significant analytical efforts. See Table 4 for check point values.

Table 5 -- Status of verification

\begin{tabular}{l|l}
\hline \multicolumn{1}{c|}{ Verified Parameters } & \multicolumn{1}{c}{ Unverified Parameters } \\
\hline Upper Layer Temperature (1) & Ambient Target (1) \\
Lower Layer Temperature (1) & Floor Target (1) \\
Layer Height (1) & Target Temperature (2) \\
Upper Layer Volume (1) & Target Flux (2) \\
Pressure (1) & Target Fire Radiation (2) \\
Main Plume Flow & Target Surface Radiation (2) \\
Main Pyrolysis Rate & Target Gas Radiation (2) \\
Main Fire Size & Target Convection (2) \\
Main Flame Height & Upper \& Lower $\mathrm{N}_{2}(1)$ \\
Main Convection Size & Upper \& Lower CO (1) \\
Target Temperature (1) & Upper \& Lower CO (1) \\
Target Flux (1) & Upper \& Lower HCN (1) \\
Target Fire Radiation (1) & Upper \& Lower HCL (1) \\
Target Surface Radiation (1) & Upper \& Lower TUHC (1) \\
Target Gas Radiation (1) & Upper \& Lower H $\mathrm{O}_{2}(1)$ \\
Target Convection (1) & Upper \& Lower OD (1) \\
Upper O (1) & Upper \& Lower HCl c (1) ${ }^{1}$ \\
Lower O (1) & Upper \& Lower HCl uw (1) ${ }^{1}$ \\
Upper Inflow 1-Outside (1) & Upper \& Lower HCl lw (1) \\
Upper Outflow 1-Outside (1) & Upper \& Lower HCl f (1) \\
Lower Inflow 1-Outside (1) & \\
Lower Outflow 1-Outside (1) & \\
\hline
\end{tabular}




\section{WORKS CITED}

1 Peacock, R. D., Paul A. Reneke, Walter W. Jones, Rebecca M. Portier, and Glenn P. Forney. 1993. CFAST, the Consolidated Model of Fire Growth and Smoke Transport. Gaithersburg: MD. National Institute of Standards and Technology. (February) NIST Technical Note 1299.

2 Peacock, R. D., Paul A. Reneke, Richard W. Bukowski, and Glenn P. Forney. 2000. A User's Guide for FAST: Engineering Tools for Estimating Fire Growth and Smoke Transport. Gaithersburg: MD. National Institute of Standards and Technology. (March) NIST Special Publication 921.

3 Peacock, R. D., Paul A. Reneke, Walter W. Jones, and Glenn P. Forney. 2000. A Technical Reference for CFAST: An Engineering Tool for Estimating Fire and Smoke Transport. Gaithersburg: MD. National Institute of Standards and Technology. (January) NIST Technical Note 1431.

4 Deal, Scot. 1995. Technical Reference Guide for FPEtool Version 3.2. Gaithersburg: MD. National Institute of Standards and Technology. Building and Fire Research Laboratory. (April) NISTIR 5486-1.

5 Gross, Daniel. 1985. Data Sources for Parameters Used in Predictive Modeling of Fire Growth and Smoke Spread. Gaithersburg: MD. U. S. Department of Commerce. Center for Fire Research. (September) NBSIR 85-3223.

6 "Software Quality Assurance". 2001. In WSRC 1Q Quality Assurance Manual. Westinghouse Savannah River Company. (28 February) Procedure 20-1.

7 "Software Quality Assurance". 2001. In WSMS 1Q WSMS Quality Assurance Manual. Westinghouse Safety Management Solutions. (April) Procedure 4-4, Revision 1.

8 Petty, J. T. 2000. Status Report on WSMS Software Verification and Validation Activities for FAST 3.1.6 $(U)$. Aiken, SC: Westinghouse Safety Management Solutions LLC. (25 September) WSRC-RP-2000-00802.

9 International Collaborative Project to Evaluate Fire Models for Nuclear Power Plant Applications: Summary of $2^{\text {nd }}$ Meeting. 2000. Washington, DC: U.S. Nuclear Regulatory Commission, Office of Nuclear Regulatory Research. (June 19-20) NUREG/CP-0173.

10 Coutts, D. A. 2000. $V \& V$ of CFAST and FAST - Software Development Plan (U). Memo to J. Gingera. (June 9) WSMS-SAE-00-0206. 
11 Martin, A. R. 2001. Thermal Properties for FAST Database. Aiken, SC: Westinghouse Safety Management Solutions LLC. (August) F-CLC-G-00023, Revision 1.

12 Martin, A. R. 2001. Verification and Validation of FAST Mechanical Ventilation Flow. Aiken, SC: Westinghouse Safety Management Solutions LLC. (October) F-CLC-H00019, Revision 0. 
WSRC-TR-2001-00405

This page intentionally blank. 
WSRC-TR-2001-00405

Appendix 1 - Benchmark Exercise 


\section{International Collaborative Project to Evaluate Fire Models for Nuclear Power Plant Applications}

Benchmark Exercise \# 1

Cable Tray Fires of Redundant Safety Trains

(Revised September 11, 2000) 


\section{Definition of Scenario}

\section{(Revised September 11, 2000)}

The project plan describes the background and choice of scenarios relating to cable tray fires of redundant safe-shutdown systems as the first benchmark exercise to be conducted in this project. The project plan also describes this task in general terms in Section 5.1.4 and 9.2.1.

\section{Background}

The objective of the fire modeling analyses in a probabilistic risk analysis (PRA) is to estimate the conditional probability of safe-shutdown equipment damage given a fire. Fire modeling results are necessary in order to make this estimate. The main fire protection features that affect the development of a fire are:

1. Automatic fire detection (detection by operators is also important)

2. Automatic isolation of the fire rooms with gaseous suppression systems by the closure of fire doors and dampers, and manual isolation of rooms with non-gaseous suppression systems.

3. Fire suppression (automatic and manual)

The target damage time is compared with the duration of a specific sequence identified in an event tree formulated to model the possible combinations of the above events. The conditional probability of the safe shutdown equipment damage is the probability of that sequence, if the damage time is less than the sequence duration.

Given the state of the art of fire modeling, the adequacy of fire detection and suppression is normally not included in fire modeling analyses to support a PRA. Therefore, this benchmark exercise does not include the evaluation of these systems or events.

\section{Discussion}

The benchmark exercise is intended to be for a simple scenario defined in sufficient detail to allow evaluation of the physics modeled in the fire computer codes. This approach will be similar to that adopted by the CIB W14 effort for code assessment. An assessment of appropriate input parameters and assumptions, interpretation of results, and determining the adequacy of the physical models in the codes for specific scenarios will establish useful technical information regarding the capabilities and limitations of the codes. This valuable information will be documented in a technical reference manual for fire model users. Generic insights regarding the capabilities of the models will also be developed in this process and documented.

The comparisons between codes can be used to understand the modeling of the physics in them, i.e. if all the codes produce similar results over a range of scenarios then the physics modeled in the codes is probably adequate for this scenario. However, the compounding effects of different phenomena will also need to be evaluated. Some variations in the results may be acceptable depending on how the results will be used. Uncertainties in the predictions based on validations of each code will be discussed and provide a basis for the confidence on the set of results developed in the exercise. 


\section{Procedure}

1. Analysts should discuss and agree on the input data for the various codes that will be used in the benchmark exercise. The goal is for participants to analyze the same problem and minimize the variation of results due to differing input data. User effects will be examined at a later stage.

2. The form of the results to be compared should be agreed upon by participants prior to the commencement of the exercise.

3. Developers of the fire codes, and those not involved in the development of the codes, can conduct the code analyses for the benchmark exercise.

4. Blind simulations should be conducted, i.e. each analyst will conduct his or her analyses independently, and simultaneously share results with others when analyses by all the participants have been completed and results are available. The results could be simultaneously posted on the web site prior to a meeting of the participants to allow some questions or discussion on the web before the semi-annual meeting.

5. If desired, the same code (e.g. CFAST) can be used by different organizations since this will provide useful information on whether the results vary with different users. However, the same version of the code should be used (for CFAST, use Version 3.1.6).

6. A series of benchmark exercises will be defined and conducted in this project. This will allow the evaluation of the full spectrum of fire model features and applications, and facilitate formulation of a comprehensive technical reference for users on the capabilities and limitations of the current state-ofthe-art models.

\section{Fire Codes to be Used}

The following fire codes will be used in this benchmark exercise by the organizations listed that are participating in the exercise.

\section{Organization \\ $\underline{\text { Codes }}$}

1. IPSN

2. NRC/NIST

3. GRS

4. VTT

5. EDF

6. BRE/NII

7. WPI (may be)
FLAMME-S (zone)

CFAST (zone), FDS $^{1}$ (CFD)

COCOSYS (lumped parameter),

CFX (CFD) [may be]

CFAST

MAGIC (zone)

CFAST, JASMINE (CFD)

WPIFIRE (zone)

\footnotetext{
${ }^{1}$ Exploratory and preliminary analysis will be conducted with the FDS code.
} 


\section{Definition}

\section{Room Size and Geometry}

A representative PWR emergency switchgear room is selected for this benchmark exercise. The

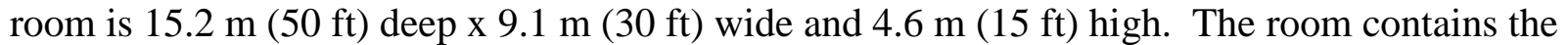
power and instrumentation cables for the pumps and valves associated with redundant safeshutdown equipment. The power and instrument cable trays associated with the redundant safeshutdown equipment run the entire depth of the room, and are arranged in separate divisions and separated horizontally by a distance, $\mathrm{D}$. The value of $\mathrm{D}$, the safe separation distance, is varied and examined in this problem. The cable trays are $0.6 \mathrm{~m}(\sim 24 \mathrm{in}$.$) wide and 0.08 \mathrm{~m}(\sim 3 \mathrm{in}$. deep.

A simplified schematic of the room, illustrating critical cable tray locations, is shown in the attached figure. The postulated fire scenario is the initial ignition of the cable tray labeled as "A", located at $0.9 \mathrm{~m}$ $(\sim 3 \mathrm{ft})$ from the right wall of the room at an elevation of $2.3 \mathrm{~m}(7.5 \mathrm{ft})$ above the floor, by a trash bag fire on the floor. Cables for the redundant train are contained in another tray, labeled "B," the target. A horizontal distance, $\underline{\mathrm{D}}$, as shown in the attached figure separates tray B from tray A. The room has a door, $2.4 \mathrm{~m} \times 2.4 \mathrm{~m}(8 \mathrm{ft} \times 8 \mathrm{ft}$ ), located at the midpoint of the front wall, assumed to lead to the outside. The room has a mechanical ventilation system with a flowrate of 5 volume changes per hour in and out of the room. Assume a constant flowrate in the mechanical ventilation system. The midpoint of the vertical vents for the supply and exhaust air are located at an elevation of $2.4 \mathrm{~m}$ and have area of $0.5 \mathrm{~m}^{2}$ each. Assume vents are square and located at the center of the side walls (parallel to the cable trays). Assume air is supplied from the outside through the right wall, and exhausted to the outside from the left wall.

The effects of the fire door being open or closed, and the mechanical ventilation on and off will be examined.

It is assumed that:

- Other cable trays ( $\mathrm{C} 1$ and $\mathrm{C} 2)$ containing critical and non-critical cables are located directly above tray A.

- No combustible material intervenes between trays A and B.

Analyses

There are two parts to the analyses.

The objective of Part I is to determine the maximum horizontal distance between a specified transient fire and tray A that results in the ignition of tray A. This information is of use in a fire PRA to calculate the area reduction factor for the transient source fire frequency, which are derived to be applicable to the total area of the rooms. Analyses of this part of the problem will also provide insights regarding the capabilities of the models to predict simpler fire scenarios for risk analyses than those associated with fires of redundant cable trays.

Part II will determine the damage time of the target cable tray B for several heat release rates of the cable tray stack (A, C2, and C1), and horizontal distance, D. The effects of target elevation and ventilation will also be examined. 
Thermophysical Data for Walls, Floor, and Ceiling (Concrete)

\begin{tabular}{|l|l|}
\hline Specific Heat & $1000 \mathrm{~J} / \mathrm{KgK}$ \\
\hline Conductivity & $1.75 \mathrm{~W} / \mathrm{mK}$ \\
\hline Density & $2200 \mathrm{Kg} / \mathrm{m} 3$ \\
\hline Emissivity & 0.94 \\
\hline
\end{tabular}

Assume the walls, floor and ceiling are $152 \mathrm{~mm}$ thick.

Thermophysical Data for Cables

\begin{tabular}{|l|l|}
\hline Heat of combustion of insulation & $16 \mathrm{MJ} / \mathrm{kg}$ \\
\hline Fraction of flame heat released as radiation & 0.48 \\
\hline Density & $1710 \mathrm{~kg} / \mathrm{m} 3$ \\
\hline Specific Heat & $1040 \mathrm{~J} / \mathrm{kgK}$ \\
\hline Thermal Conductivity & $0.092 \mathrm{~W} / \mathrm{mK}$ \\
\hline Emissivity & 0.8 \\
\hline
\end{tabular}

\section{Chemical Properties of Cables 2}

Assume cable insulation is PVC - polyvinyl chloride. Chemical formula is $\mathrm{C}_{2} \mathrm{H}_{3} \mathrm{Cl}$. The oxygen-fuel mass ratio $=1.408$. The yields (mass of species/mass of fuel) are listed in the following Table.

Yields for PVC

\begin{tabular}{|c|c|}
\hline Species & Yield \\
\hline $\mathrm{CO}_{2}$ & 0.46 \\
\hline $\mathrm{CO}$ & 0.063 \\
\hline $\mathrm{HCl}$ & 0.5 \\
\hline $\mathrm{Soot}$ & 0.172 \\
\hline
\end{tabular}

Assume the Smoke Potential of PVC $=1.7$ ob.m3/g, where the smoke potential is defined as the optical density $(\mathrm{dB} / \mathrm{m}$ or ob) $\mathrm{x}$ Volume of the compartment $(\mathrm{m} 3) /$ mass of the fuel pyrolyzed $(\mathrm{g})$.

Ambient Conditions (Internal and External)

\begin{tabular}{|l|l|}
\hline Temperature & $300 \mathrm{~K}$ \\
\hline Relative Humidity & 50 \\
\hline Pressure & $101300 \mathrm{~Pa}$ \\
\hline Elevation & 0 \\
\hline Wind Speed & 0 \\
\hline
\end{tabular}

Other Constants and Indices

\begin{tabular}{|l|l|}
\hline Constriction coefficient for flow through door & 0.68 \\
\hline $\begin{array}{l}\text { Convective heat transfer coefficient } \\
\text { (assume same for all surfaces) }\end{array}$ & $15 \mathrm{Wm}^{-2} \mathrm{~K}^{-1}$ \\
\hline Lower Oxygen Limit & $12 \%{ }^{3}$ \\
\hline
\end{tabular}

2 Tewarson, A, "Generation of Heat and Chemical Compounds in Fires," SFPE Handbook of Fire Protection Engineering, $2^{\text {nd }}$ Edition, 3-53 to 3-124, 1995. 
Construction and Properties of Fire Door 4

The following are properties of the fire door for use in models that allow the incorporation of such features. Assume fire door is a metal-clad door with a wood core, and insulating panels between the wood core and the metal clad (on both sides of the wood core). Assume metal clad $=0.6 \mathrm{~mm}$, wood core $=40 \mathrm{~mm}$, and insulating panel $=3 \mathrm{~mm}$.

Properties of Fire Door

\begin{tabular}{|l|l|l|l|}
\hline & $\begin{array}{l}\text { Conductivity } \\
(\mathrm{W} / \mathrm{mC})\end{array}$ & $\begin{array}{l}\text { Density } \\
\left(\mathrm{Kg} / \mathrm{m}^{3)}\right.\end{array}$ & $\begin{array}{l}\text { Specific Heat } \\
(\mathrm{kJ} / \mathrm{KgC})\end{array}$ \\
\hline Metal Clad - Carbon Steel & 43 & 7801 & 0.473 \\
\hline Wood Core - Yellow Pine & 0.147 & 640 & 2.8 \\
\hline Fiber, insulating panel & 0.048 & 240 & \\
\hline
\end{tabular}

\section{$\underline{\text { Input Data for Part I }}$}

\section{Heat Release Rates}

Assume heat release rate for a trash fire ${ }^{5}$ as characterized in the following Table (assume linear growth between points).

\section{Gallon Trash Bag Fire}

\begin{tabular}{|l|l|}
\hline Time (minutes) & Heat Release Rate $(\mathrm{kW})$ \\
\hline 1 & 200 \\
\hline 2 & 350 \\
\hline 3 & 340 \\
\hline 4 & 200 \\
\hline 5 & 150 \\
\hline 6 & 100 \\
\hline 7 & 100 \\
\hline 8 & 80 \\
\hline 9 & 75 \\
\hline 10 & 100 \\
\hline
\end{tabular}

The trash bag consists of: (1) straw and grass cuttings $=1.55 \mathrm{~kg}$; (2) eucalyptus duff $=2.47 \mathrm{~kg}$; and (3) polyethylene bag $=0.04 \mathrm{~kg}$. Contents were thoroughly mixed, and then placed in the bag in a loose manner. Approximate the trash bag as a cylinder with a diameter $=0.49 \mathrm{~m}$ and height

\footnotetext{
3 The fire source should pyrolyze at a rate corresponding to the specified heat release rate in Part II if oxygen depletion terminates combustion, i.e., the mass release rate of the fuel is fixed rather than the "true" heat release rate associated with the oxidation process.

${ }^{4}$ Derived from information in NFPA 80 and SFPE Handbook.

5 Lee, B. T., "Heat Release Rate Characteristics of Some Combustible Fuel Sources in Nuclear Power Plants," NBSIR 85-3195, National Bureau of Standards, 1985; and

Van Volkinburg, D. R. et al, “Toward a Standard Ignition Source,” Paper No. 78-64, Lawrence Berkeley Laboratory, University of California, Berkeley, California, 1978.
} 
$=0.62 \mathrm{~m}$. Assume the fraction of heat released as radiation is 0.3 , and the heat of combustion of the trash bag material $=24.1 \mathrm{MJ} / \mathrm{Kg}$.

Assume the trash bag and the target (representing tray A) are at the center of the cable tray lengths. In order to conduct a simplified and conservative analysis, assume the target is a single power cable with a diameter $=50 \mathrm{~mm}$ at the bottom left corner of the cable tray A. For models in which targets are represented as a rectangular slab, assume the slab is oriented horizontally with a thickness of $50 \mathrm{~mm}$. Assume the cable ignites when the centerline of the cable reaches $643 \mathrm{~K}$.

\section{Base case}

Distance between the midpoints of the trash bag and tray $\mathrm{A}=2.2 \mathrm{~m}(\sim 7 \mathrm{ft})$, the door is closed, and mechanical ventilation system is off.

\section{Variation of Parameters}

A. To facilitate comparisons of code results, simulations for horizontal distances between the trash bag and tray $\mathrm{A}$ of $0.3,0.9$, and $1.5(\sim 1, \sim 3$, and $\sim 5 \mathrm{ft})$ should be conducted (Cases 1-3)

B. Simulations should also be conducted with (a) the door open and mechanical system off; and (b) mechanical ventilation system on and door closed (Cases 4-5).

Summary of Cases for Part I

\begin{tabular}{|l|l|l|l|}
\hline & Distance from Fire & Door & Ventilation System \\
\hline Base Case & $2.2 \mathrm{~m}$ & Closed $^{*}$ & Off \\
\hline Case 1 & $0.3^{+}$ & & \\
\hline Case 2 & 0.9 & & \\
\hline Case 3 & 1.5 & & \\
\hline Case 4 & & Open & \\
\hline Case 5 & & & On \\
\hline
\end{tabular}

* For simulations with the door closed, assume a crack $(2.4 \mathrm{~m} \mathrm{x} 0.005 \mathrm{~m})$ at the bottom of the doorway.

${ }^{+} \mathrm{A}$ value in a cell indicates the parameter is varied from the base case.

The maximum horizontal distance between the trash bag and tray A, that results in the ignition of tray A, should be determined by extrapolation of results for the simulations with the door closed and mechanical ventilation system off (Base case to Case 3).

The resulting centerline temperature of the cable should be presented for these simulations. In addition, the following parameters should be reported:

- Upper layer temperature

- Lower layer temperature

- Depth of the hot gas layer

- Heat release rate

- Oxygen content ${ }^{6}$ (upper and lower layer)

\footnotetext{
${ }^{6}$ Neglect any oxygen present in the fuel in the calculation of the oxygen concentration in the compartment.
} 
- Flow rates through door and vents

- Radiation flux on the target

- Target surface temperature

- Total heat loss to boundaries

For CFD and lumped-parameter models, the profile at the midpoint of the room should be presented.

All results should be presented in SI units.

Input Data for Part II

\section{Heat Release Rates}

The modeling of and predicting the heat release rate of a burning cable tray stack is extremely complex, and current models are not capable of realistically predicting such phenomena. Therefore, the heat release rates of the burning cable tray stack is defined as input in the problem. The consecutive ignition and burning of all 3 cable trays (trays A, C2, and C1) will be modeled as one fire. Conduct analyses assuming peak heat release rate for the whole cable tray stack between $1-3 \mathrm{MW}^{7}$. Assume t-squared growth with $\mathrm{t}_{0}=10$ min., and $\mathrm{Q}_{0}=1 \mathrm{MW}^{8}$.

$$
\mathrm{Q}=\mathrm{Q}_{0}\left(\mathrm{t} / \mathrm{t}_{0}\right)^{2}
$$

Assume a fire duration of 60 minutes at peak heat release rate, and then a t-squared decay with similar constants as for growth.

\section{Geometry}

For point source calculations, assume the heat source (trays A, C2, and C1) is at the center of the cable tray length and width and at the elevation of the bottom of tray $\mathrm{C} 2$. For 3-D calculations, assume the fire source is the entire length of tray C2 $(15.2 \mathrm{~m})$, width $(0.6 \mathrm{~m})$, and height of $0.24 \mathrm{~m}(0.08 \times 3)$. Assume the target (representing tray B) is at the center of the cable tray length. In order to conduct a simplified and conservative analysis, assume the target is a single power or instrumentation cable with no electrical conductor inside the cable, and with a diameter of $50 \mathrm{~mm}$ or $15 \mathrm{~mm}$ respectively at the bottom right corner of cable tray B. For models in which targets are represented as a rectangular slab, assume the slab is oriented horizontally with a thickness of $50 \mathrm{~mm}$ or $15 \mathrm{~mm}$. Assume the cable is damaged when the centerline of the cable reaches $200 \mathrm{C}$.

\footnotetext{
7 The 1-3 MW range was chosen as bounding values for a stack of 3 cable trays. Considering a heat of combustion of $25 \mathrm{MJ} / \mathrm{Kg}$ and a surface controlled specific mass loss rate of about $3 \mathrm{~g} / \mathrm{m}^{2}$-sec for cables that pass the IEEE tests, a cable tray $15 \mathrm{~m}$ long and $0.6 \mathrm{~m}$ wide will have an effective heat release rate of $0.9 \mathrm{MW}$. An earlier study (NUREG/CR-4230), and fire tests reported in EPRI NP-2660 and EPRI NP-2751 also concluded that the peak heat release rate for a cable tray is limited from 0.8 to $2 \mathrm{MW}$ for a well ventilated room.

${ }^{8}$ EdF CNPP tests (1997)
} 


\section{Base Case}

Heat Release Rate for cable tray stack $=1 \mathrm{MW}$ (reaching peak heat-release rate and decaying as specified above) at a horizontal distance, $\mathrm{D}=6.1 \mathrm{~m}(20 \mathrm{ft})$. Door is closed and ventilation system is off. Target is a power cable $1.1 \mathrm{~m}(3.5 \mathrm{ft})$ above tray A.

\section{Variation of Parameters}

A. Vary $\mathrm{D}=3.1,4.6 \mathrm{~m}(\sim 10, \sim 15 \mathrm{ft})-$. Cases $1-2$

B. Vary peak heat release rate for cable tray stack $=2 \mathrm{MW}$, and $3 \mathrm{MW}$ (reaching peak heat-release rate and decaying as specified above) at a horizontal distance, $\mathrm{D}=3.1,4.6,6.1 \mathrm{~m}$ (Cases 3-8).

C. Door closed and ventilation system operational initially; and door opened, and ventilation system shut after 15 minutes (Case 9).

D. Door and ventilation system open throughout the simulation (Case 10).

E. Two elevations for tray B should be analyzed to examine the possible effects of the ceiling jet sublayer and the elevation of the target:

- $2.0 \mathrm{~m}(6.5 \mathrm{ft})$ above tray A, (i.e., $0.3 \mathrm{~m}(1 \mathrm{ft})$ below the ceiling) - Case 11

- Same elevation as tray A - Case 12

F. Instrumentation cable with diameter $=15 \mathrm{~mm}$ (Case 13)

The resulting centerline temperature of the target, and time to damage of target, should be presented for these analyses. In addition, the following parameters should be reported:

- Upper layer temperature

- Lower layer temperature

- Depth of the hot gas layer

- Heat release rate

- Oxygen content (upper and lower layer)

- Flow rates through door and vents

- Radiation flux on the target

- Target surface temperature

- Total heat loss to boundaries

- Chemical species (CO, $\mathrm{HCl}$, soot) in upper layer

- Optical density of smoke (optional)

For CFD and lumped-parameter models, the profile at the midpoint of the room should be presented.

All results should be presented in SI units. 
$\underline{\text { Summary of Cases for Part II }}$

\begin{tabular}{|c|c|c|c|c|c|c|}
\hline & HRR (MW) & $\mathrm{D}(\mathrm{m})$ & Door & Vent. Sys. & Target & Elev. (m) \\
\hline Base Case & $1 \mathrm{MW}$ & 6.1 & Closed $^{*}$ & Off & Power & 1.1 \\
\hline Case 1 & & $3.1^{+}$ & & & & \\
\hline Case 2 & & 4.6 & & & & \\
\hline Case 3 & 2 & 3.1 & & & & \\
\hline Case 4 & 2 & 4.6 & & & & \\
\hline Case 5 & 2 & 6.1 & & & & \\
\hline Case 6 & 3 & 3.1 & & & & \\
\hline Case 7 & 3 & 4.6 & & & & \\
\hline Case 8 & 3 & 6.1 & & & & \\
\hline Case 9 & & & Open $>15$ min & Off $>15 \mathrm{~min}$ & & \\
\hline Case 10 & & & Open & On & & \\
\hline Case 11 & & & & & & 2.0 \\
\hline Case 12 & & & & & & Same \\
\hline Case 13 & & & & & Instrument & \\
\hline
\end{tabular}

* For simulations with the door closed, assume a crack $(2.4 \mathrm{~m} \mathrm{x} 0.005 \mathrm{~m})$ at the bottom of the doorway.

${ }^{+} \mathrm{A}$ value in a cell indicates the parameter is varied from the base case. 
WSRC-TR-2001-00405

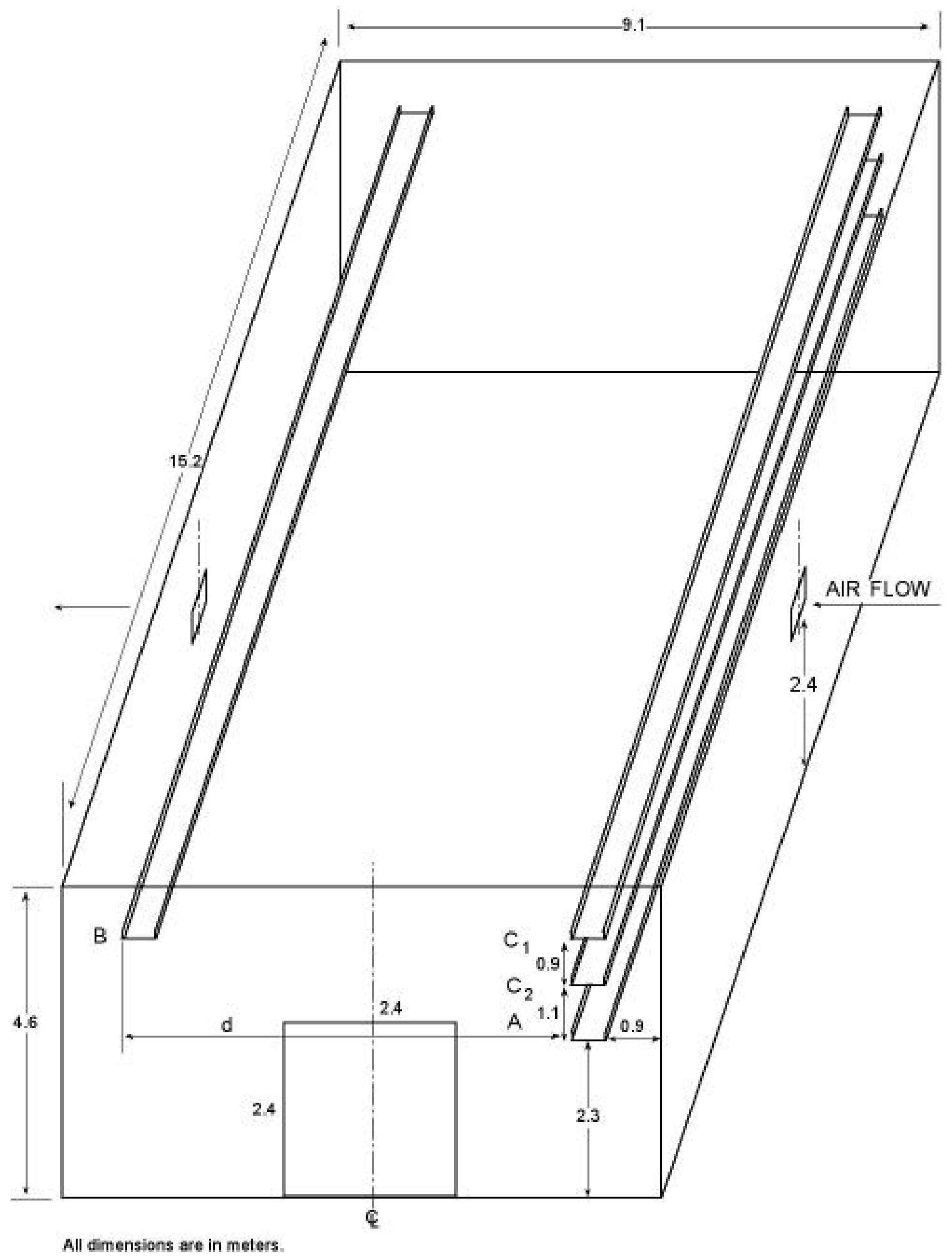

Representative PWR Emergency Switchgear Room 


\section{Attachment \\ Comments on Proposed Definition of Benchmark Exercise and Disposition of Issues}

The following comments were discussed and resolutions developed at the meeting on June 19-20, 2000 at IPSN in Fontenay-aux-Roses, France.

1. Issue: Should user effects be addressed?

Disposition: Minimize user effects now, and address issue later

2. Issue: Mechanical ventilation rate

$2-5 \mathrm{vol} . / \mathrm{hr}$ is more realistic

zone models not valid for high ventilation rates

Disposition: Use 5 vol./hr

3. Issue: Location of doors and vents for use in CFD and lumped parameter models

Disposition: Assume door is located at the center of the front wall, and the vents at the center of the side walls.

4. Issue: Specify content and dimensions (including floor area) of trash bag fire source

Disposition:Contents: (1) straw and grass cuttings $=1.55 \mathrm{~kg}$; (2) eucalyptus duff $=2.47 \mathrm{~kg}$; and (3) polyethylene bag $=0.04 \mathrm{~kg}$. Contents were thoroughly mixed, and then placed in the bag in a loose manner.

Dimensions: Assume cylindrical geometry with diameter $=0.492 \mathrm{~m}$ and height $=0.615 \mathrm{~m}$

5. Issue: The curve for the HRR of the trash bag fire should be specified

Disposition: Assume a linear fit between points. Specifying the best curve to go through the data points from the experiments may introduce more error than assuming a linear interpolation between the points.

6. Issue: The heat release rate curves of cable tray fires should be based on experiments. Experiments have shown that peak heat release rates for cable fires generally do not last more than 60 minutes.

Disposition: A t-squared growth is appropriate for modeling cable tray fires. The HRR curves will be chosen based on experiments conducted by EdF. Assume t-squared growth with $\mathrm{t}_{0}=10 \mathrm{~min}$., and $\mathrm{Q}_{0}=1 \mathrm{MW}$.

$$
\mathrm{Q}=\mathrm{Q}_{0}\left(\mathrm{t} / \mathrm{t}_{0}\right)^{2}
$$

Assume a fire duration of 60 minutes at peak heat release rate, and then a t-squared decay with similar constants as for growth. 
7. Issue: The type and dimensions of the cables need to be specified in more detail to allow more detailed modeling of heat transfer to the cables.

Disposition: Power cables $=50 \mathrm{~mm}$ diam., and instrument cables $=15 \mathrm{~mm}$ diam. For models in which targets are represented as rectangular slabs, assume slabs are oriented horizontally with a thickness of $50 \mathrm{~mm}$ and $15 \mathrm{~mm}$ correspondingly.

Open Issue (raised by Remy Bertrand): Are the slab dimensions too thick and have an inertia greater than reality? In principle, the integral protective overjacket is 1 to $2 \mathrm{~mm}$ thick.

8. Issue: Some codes require the specification of a large leakage opening (when doors and vents are closed) for successful code execution (e.g., HAVARD 6)

Disposition: Maintain leakage value specified in draft problem definition. Users of codes with limitation should adjust value as needed, and document value used.

9. Issue: Should corner/wall effects be examined? In practice, cable trays are installed nearer than 0.9 $\mathrm{m}$ from walls. Should transient combustibles in the corner or along walls be considered?

Disposition: In order to minimize the number of cases for the benchmark exercise, corner/wall effects will not be examined now but at a later stage. However, model users may run additional cases to examine issue, and present results to other participants.

10. Issue: What temperature in the cable should be used to establish the criteria for cable damage temperature? The outside cable surface temperature is not indicative of effects on cable functionality. IPSN experiments indicate that the temperature at the inside surface of the insulation is about $200 \mathrm{C}$ when malfunction occurs.

Disposition: Use the centerline temperature, and criteria for damage $=200 \mathrm{C}$

11. Issue: What value should be used for the constriction coefficient?

Disposition: Set value at 0.68

12. Issue: What value should be used for the convective heat transfer coefficient?

Disposition: Set value at $15 \mathrm{Wm}^{-2} \mathrm{~K}^{-1}$

13. Issue: What value should be used for the Lower Oxygen Limit?

Disposition: Use value of $12 \%$.

Open Issue (raised by Moni Dey): At the meeting we decided to use a value of 0 for the base case, and run one case at $12 \%$ if model allows this value to be varied. However, if the LOL is set at $0 \%$, the cases which were developed to examine the effects of ventilation will be not be useful to run. Therefore, it is suggested the LOL be set at $12 \%$ in order to examine these effects.

14. Issue: Should the structures securing cable trays be evaluated as targets in the problem? 
Disposition: In order to limit the scope of the current benchmark exercise, the modeling of cable tray structures will not be included in the analyses. However, model users may include this analysis and share the results with the other participants.

15. Issue: Should the door be open to ambient conditions outside, or to another compartment. In NPPs, doors in most compartments would open to another compartment.

Disposition: In order to simplify and make feasible the evaluation of model effects, multicompartment analysis will not be included at this stage since that would include additional considerations and effects on the results. However, modelers may evaluate the effect of this assumption on the results and share the information with other participants.

16. Issue: Intermediate results to cable temperature should be presented to allow a full evaluation of results, and for generating statistics of results.

Disposition: In addition to the cable centerline temperature, the following parameters should be reported:

- Upper layer temperature

- Lower layer temperature

- Depth of the hot gas layer

- Heat release rate

- Oxygen content (upper and lower layer)

- Flow rates through door and vents

- Radiation flux on the target

- Target surface temperature

- Total heat loss to boundaries

- Chemical species $(\mathrm{CO}, \mathrm{HCl}$, soot (C)) in upper layer

For CFD and lumped-parameter models, the profile at the midpoint of the room should be presented.

17. Issue: The physical properties (heat conductivity, density, and specific heat) and thickness of the fire door are needed.

Disposition: Assume fire door is a metal-clad door with a wood core and insulating panels between wood core and metal clad (on both sides of wood core). Assume metal clad $=0.6 \mathrm{~mm}$, wood core $=$ $40 \mathrm{~mm}$, and insulating panel $=3 \mathrm{~mm}$.

Properties of Fire Door

\begin{tabular}{|l|l|l|l|}
\hline & \multicolumn{1}{|c|}{$\begin{array}{c}\text { Conductivity } \\
\left(\mathrm{W} / \mathrm{m}^{\circ} \mathrm{C}\right)\end{array}$} & \multicolumn{1}{|c|}{$\begin{array}{c}\text { Density } \\
\left(\mathrm{Kg} / \mathrm{m}^{3)}\right.\end{array}$} & \multicolumn{1}{|c|}{$\begin{array}{c}\text { Specific Heat } \\
\left(\mathrm{kJ} / \mathrm{Kg}{ }^{\circ} \mathrm{C}\right)\end{array}$} \\
\hline Carbon Steel & 43 & 7801 & 0.473 \\
\hline Yellow Pine & 0.147 & 640 & 2.8 \\
\hline Fiber, insulating panel & 0.048 & 240 & \\
\hline
\end{tabular}


18. Issue: The chemical properties of the cables ( $\mathrm{C}, \mathrm{CL}, \mathrm{O}, \mathrm{H}$ amounts), the necessary amounts of oxygen and the yields of $\mathrm{CO}, \mathrm{CO}_{2}, \mathrm{H}_{2} \mathrm{O}$ vapor and soot should be given.

Disposition: Assume cable insulation is PVC - polyvinyl chloride. Chemical formula is $\mathrm{C}_{2} \mathrm{H}_{3} \mathrm{Cl}$. The oxygen-fuel mass ratio $=1.408$. Yields (mass of species $/$ mass of fuel) are $\mathrm{CO}_{2}$ $=0.46, \mathrm{CO}=0.063, \mathrm{HCl}=0.5$, soot $=0.172$.

The following are comments received on the revised definition of the problem for the benchmark exercise issued to participants on August 4, 2000 (which incorporated the disposition of the issues above).

1. Issue: The definition of the trash bag fire in Part I is too complicated. If the concentration of $\mathrm{O} 2, \mathrm{CO} 2, \mathrm{CO}$, and other species in the room is to be calculated, the chemical yields of the trash bag fire needs to be known. A more simple initial fire with well known chemical yields should be used.

Disposition: As indicated in the description of the problem, the intent of Part I is to exercise fire models to evaluate their capability to provide information for a fire risk assessment, namely, to determine the distance between fire source and the target cable tray that will result in the ignition of the target. This information can then be used to adjust the fire source frequency in the compartment being analyzed. Since the chemical behavior of the fuel in the combustion process does not have a significant effect on the specific desired result, the calculation of the concentrations of the chemical species in the fire scenarios for Part I should be omitted. Neglect any oxygen present in the fuel in the calculation of the oxygen concentration in the compartment for determining if the fire will be constrained as a result of lack of oxygen. Assume the heat of combustion of the trash bag material $=24.1 \mathrm{MJ} / \mathrm{Kg}$.

2. Issue: The volume of the fire source for Part II has not been specified.

Disposition: Assume the fire source is the entire length of tray C2 (15.2 m), width $(0.6 \mathrm{~m})$, and height of $0.24 \mathrm{~m}(0.08 \times 3)$.

3. Issue: The definition of heat release rate, and the LOL concept should be clarified.

Disposition: The fire source should pyrolyze at a rate corresponding to the specified heat release rate in Part II if oxygen depletion terminates combustion, i.e., the mass release rate of the fuel is fixed rather than the "true" heat release rate associated with the oxidation process.

4. Issue: The emphasis in both parts of the problem seems to be toward the "closed door" case. Considering this scenario may cause some difficulties with some models, a few more open door cases should be specified.

Disposition. The cases for the benchmark exercise were chosen to be representative of fire scenarios in nuclear power plants where the doors to most compartments would be closed, at least during the initial phase of the fire scenario. Issues related to the modeling of compartments in such configurations should be identified. Participants may analyze a broader spectrum of cases with open doors and share the results and insights generated with others. 
5. Issue: Cable trays located high in the room will probably be extinguished rapidly by oxygen depletion. Cases in Part II in which the cable trays are located at lower levels would be of interest. It would be more conservative to locate the fire source in Part II for the 3 cable trays at level A, than $\mathrm{C} 2$.

Disposition: Participants may conduct analyses of additional cases to examine the effect of cable trays being located at lower levels, and also for locating the fire source in Part II at level A, and share the results of these analyses with others.

6. Issue: The smoke opacity is not given for Part II.

Disposition: Participants that wish to calculate and report the optical density of the smoke should use a value for the Smoke Potential of $\mathrm{PVC}=1.7 \mathrm{ob} . \mathrm{m}^{3} / \mathrm{g}$, where the smoke potential is defined as the optical density $\left(\mathrm{dB} / \mathrm{m}\right.$ or ob) $\mathrm{x}$ Volume of the compartment $\left(\mathrm{m}^{3}\right) /$ mass of the fuel pyrolyzed (g).

${ }^{7}$ The fire source should pyrolyze at a rate corresponding to the specified heat release rate in Part II if oxygen depletion terminates combustion, i.e., the mass release rate of the fuel is fixed rather than the "true" heat release rate associated with the oxidation process. 
This page intentionally blank. 
Appendix 2 - Input Data File (CTFIBASE.DAT) As Provided By Dr. Dey, NIST/NRC 
$\square$ RE: FAST input file - Message [Plain Text]

File Edit View Insert Format Iools Actions Help

(1) You forwarded this message on 7/23/01 3:56 PM. Click here to find all related messages.

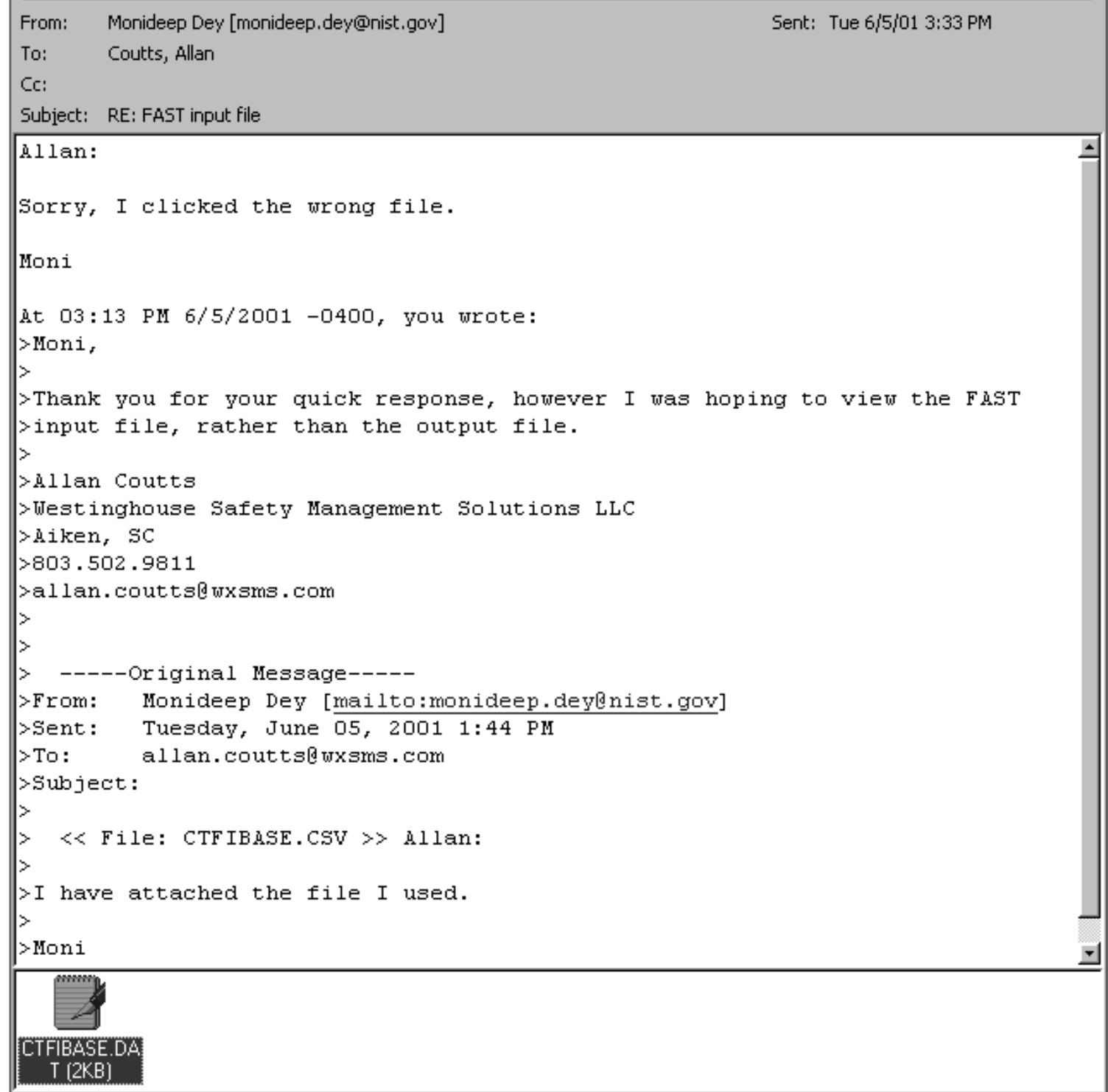


WSRC-TR-2001-00405

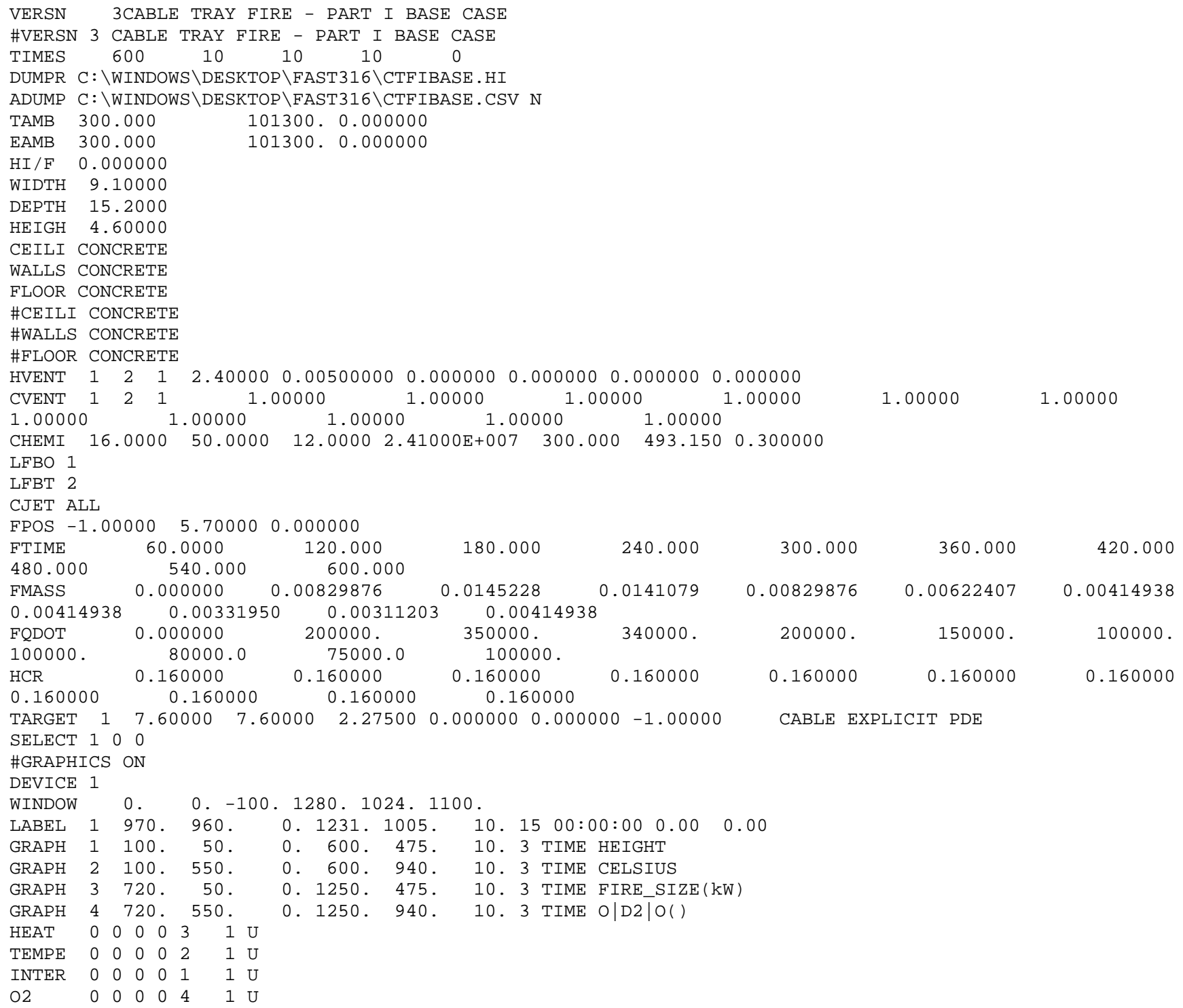


This page intentionally blank. 
Appendix 3 - Input Data File (BASECASE.DAT) as Recreated for Verification Effort 
WSRC-TR-2001-00405

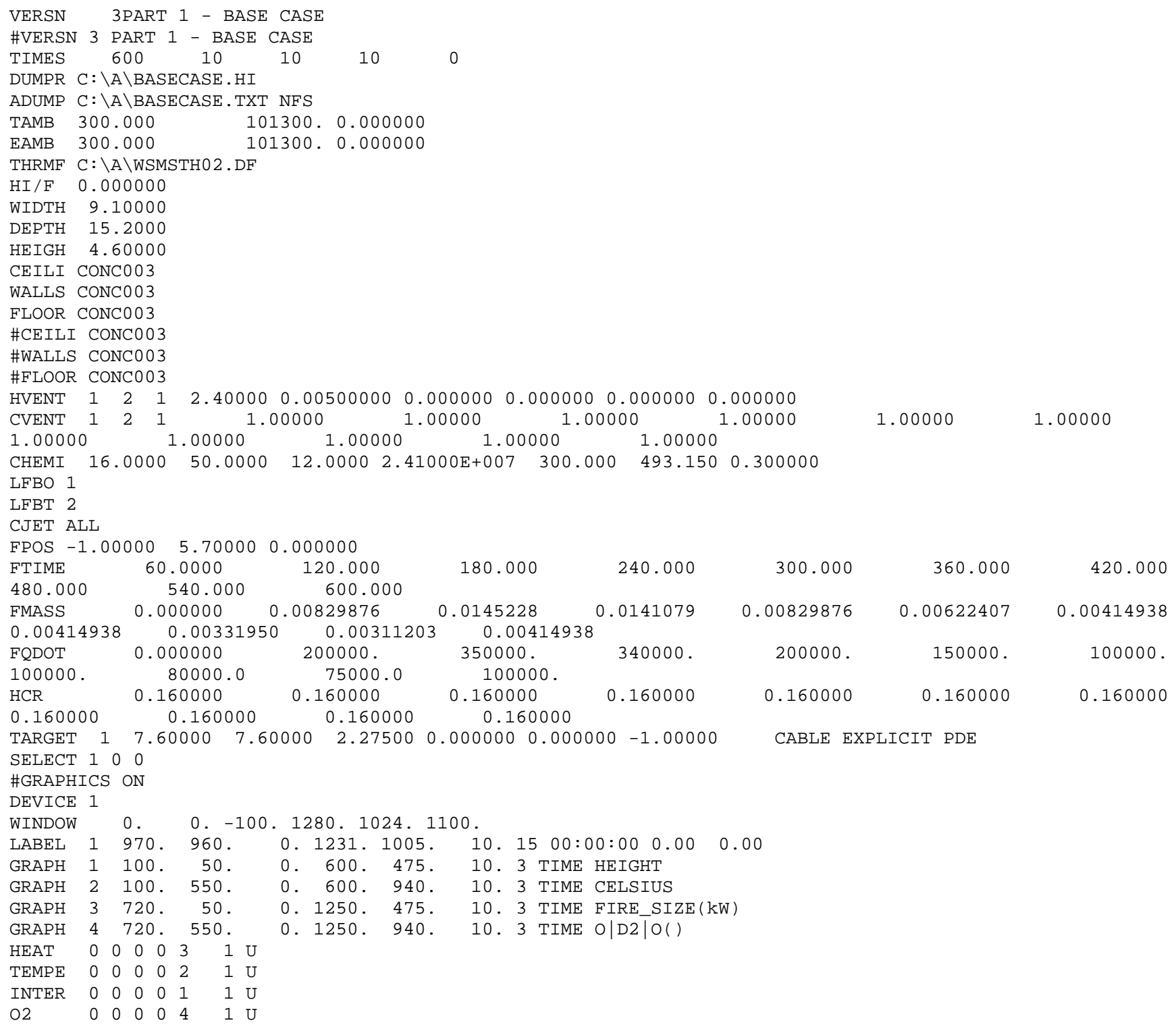


Appendix 4 - Results (CTFIBASE.CSV) as Provided by Dr. Dey, NIST/NRC 


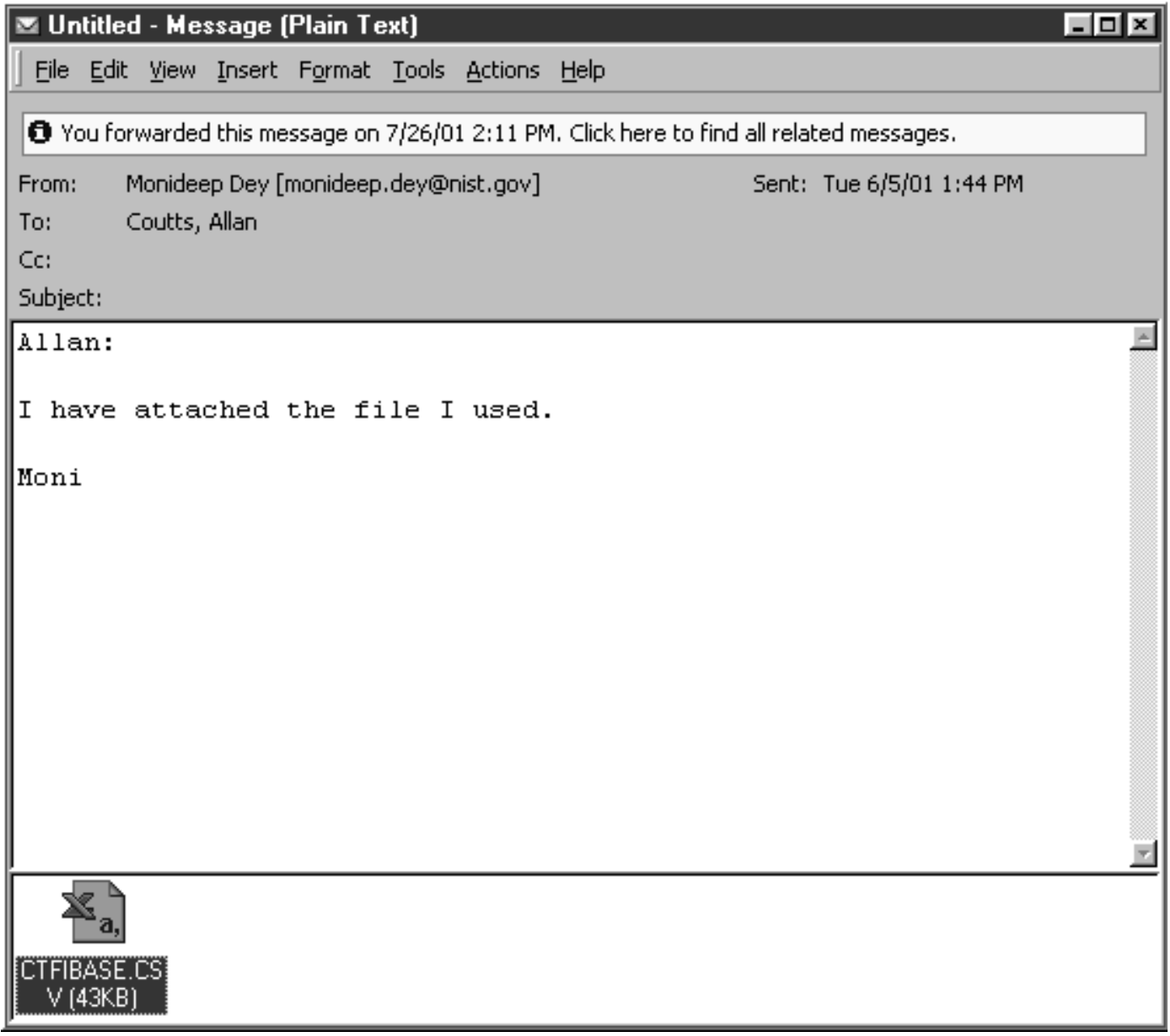


WSRC-TR-2001-00405

\begin{tabular}{|c|c|c|c|c|c|c|c|c|c|c|c|}
\hline TIME & $\begin{array}{c}\text { Upper Layer } \\
\text { Temp (1) }\end{array}$ & $\begin{array}{c}\text { Lower Layer } \\
\text { Temp (1) }\end{array}$ & $\begin{array}{c}\text { Layer Height } \\
\text { (1) }\end{array}$ & $\left|\begin{array}{c}\text { Upper Layer } \\
\text { Volume (1) }\end{array}\right|$ & Pressure (1) & $\begin{array}{l}\text { Ambient } \\
\text { Target (1) }\end{array}$ & $\begin{array}{c}\text { Floor Target } \\
\text { (1) }\end{array}$ & $\begin{array}{c}\text { Main Plume } \\
\text { Flow }\end{array}$ & $\begin{array}{c}\text { Main } \\
\text { Pyrolysis } \\
\text { Rate }\end{array}$ & $\begin{array}{c}\text { Main Fire } \\
\text { Size }\end{array}$ & $\begin{array}{l}\text { Main Flame } \\
\text { Height }\end{array}$ \\
\hline $0.00 \mathrm{E}+00$ & $3.00 \mathrm{E}+02$ & $3.00 \mathrm{E}+02$ & $4.60 \mathrm{E}+00$ & $6.36 \mathrm{E}-02$ & $-1.48 \mathrm{E}-18$ & $0.00 \mathrm{E}+00$ & $0.00 \mathrm{E}+00$ & $0.00 \mathrm{E}+00$ & $0.00 \mathrm{E}+00$ & $0.00 \mathrm{E}+00$ & $0.00 \mathrm{E}+00$ \\
\hline $1.00 \mathrm{E}+01$ & $3.03 \mathrm{E}+02$ & $3.00 \mathrm{E}+02$ & $4.37 \mathrm{E}+00$ & $3.18 \mathrm{E}+01$ & $1.85 \mathrm{E}+01$ & $2.10 \mathrm{E}+00$ & $1.72 \mathrm{E}+00$ & $4.48 \mathrm{E}+00$ & $1.38 \mathrm{E}-03$ & $3.33 \mathrm{E}+04$ & $6.04 \mathrm{E}-01$ \\
\hline $2.00 \mathrm{E}+01$ & $3.05 E+02$ & $3.00 \mathrm{E}+02$ & $4.08 \mathrm{E}+00$ & $7.23 \mathrm{E}+01$ & $7.41 \mathrm{E}+01$ & $5.57 \mathrm{E}+00$ & $4.50 \mathrm{E}+00$ & $4.65 \mathrm{E}+00$ & $2.77 \mathrm{E}-03$ & $6.67 \mathrm{E}+04$ & $8.95 \mathrm{E}-01$ \\
\hline $3.00 \mathrm{E}+01$ & $3.08 \mathrm{E}+02$ & $3.00 \mathrm{E}+02$ & $3.78 \mathrm{E}+00$ & $1.13 \mathrm{E}+02$ & $1.65 \mathrm{E}+02$ & $1.04 \mathrm{E}+01$ & $8.48 \mathrm{E}+00$ & $4.45 \mathrm{E}+00$ & $4.15 \mathrm{E}-03$ & $1.00 \mathrm{E}+05$ & $1.11 \mathrm{E}+00$ \\
\hline $4.00 \mathrm{E}+01$ & $3.10 \mathrm{E}+02$ & $3.00 \mathrm{E}+02$ & $3.50 \mathrm{E}+00$ & $1.52 E+02$ & $2.88 \mathrm{E}+02$ & $1.68 \mathrm{E}+01$ & $1.38 \mathrm{E}+01$ & $4.13 \mathrm{E}+00$ & $5.53 \mathrm{E}-03$ & $1.33 \mathrm{E}+05$ & $1.28 \mathrm{E}+00$ \\
\hline $5.00 \mathrm{E}+01$ & $3.13 E+02$ & $3.00 \mathrm{E}+02$ & $3.24 \mathrm{E}+00$ & $1.88 \mathrm{E}+02$ & $4.42 \mathrm{E}+02$ & $2.47 \mathrm{E}+01$ & $2.06 \mathrm{E}+01$ & $3.76 \mathrm{E}+00$ & $6.92 \mathrm{E}-03$ & $1.67 \mathrm{E}+05$ & $1.42 \mathrm{E}+00$ \\
\hline $6.00 \mathrm{E}+01$ & $3.16 \mathrm{E}+02$ & $3.01 \mathrm{E}+02$ & $3.00 \mathrm{E}+00$ & $2.21 \mathrm{E}+02$ & $6.25 \mathrm{E}+02$ & $3.43 \mathrm{E}+01$ & $2.89 \mathrm{E}+01$ & $3.39 \mathrm{E}+00$ & $8.30 \mathrm{E}-03$ & $2.00 \mathrm{E}+05$ & $1.55 \mathrm{E}+00$ \\
\hline $7.00 \mathrm{E}+01$ & $3.19 E+02$ & $3.01 E+02$ & $2.78 \mathrm{E}+00$ & $2.52 \mathrm{E}+02$ & $8.17 \mathrm{E}+02$ & $4.51 \mathrm{E}+01$ & $3.84 \mathrm{E}+01$ & $3.02 E+00$ & $9.34 \mathrm{E}-03$ & $2.25 \mathrm{E}+05$ & $1.64 \mathrm{E}+00$ \\
\hline $8.00 \mathrm{E}+01$ & $3.22 \mathrm{E}+02$ & $3.01 \mathrm{E}+02$ & $2.58 \mathrm{E}+00$ & $2.80 \mathrm{E}+02$ & $1.01 E+03$ & $5.72 \mathrm{E}+01$ & $4.93 \mathrm{E}+01$ & $2.68 \mathrm{E}+00$ & $1.04 \mathrm{E}-02$ & $2.50 \mathrm{E}+05$ & $1.72 \mathrm{E}+00$ \\
\hline $9.00 \mathrm{E}+01$ & $3.25 \mathrm{E}+02$ & $3.01 E+02$ & $2.39 \mathrm{E}+00$ & $3.05 \mathrm{E}+02$ & $1.20 \mathrm{E}+03$ & $7.07 \mathrm{E}+01$ & $6.16 \mathrm{E}+01$ & $2.39 \mathrm{E}+00$ & $1.14 \mathrm{E}-02$ & $2.75 \mathrm{E}+05$ & $1.80 \mathrm{E}+00$ \\
\hline $1.00 \mathrm{E}+02$ & $3.29 \mathrm{E}+02$ & $3.01 \mathrm{E}+02$ & $2.22 \mathrm{E}+00$ & $3.29 \mathrm{E}+02$ & $1.40 \mathrm{E}+03$ & $8.58 \mathrm{E}+01$ & $7.53 \mathrm{E}+01$ & $2.12 \mathrm{E}+00$ & $1.24 \mathrm{E}-02$ & $3.00 \mathrm{E}+05$ & $1.87 \mathrm{E}+00$ \\
\hline $1.10 \mathrm{E}+02$ & $3.32 \mathrm{E}+02$ & $3.01 \mathrm{E}+02$ & $2.07 \mathrm{E}+00$ & $3.50 \mathrm{E}+02$ & $1.61 \mathrm{E}+03$ & $1.02 \mathrm{E}+02$ & $9.05 E+01$ & $1.88 \mathrm{E}+00$ & $1.35 \mathrm{E}-02$ & $3.25 \mathrm{E}+05$ & $1.94 \mathrm{E}+00$ \\
\hline $1.20 \mathrm{E}+02$ & $3.36 \mathrm{E}+02$ & $3.02 E+02$ & $1.92 \mathrm{E}+00$ & $3.70 \mathrm{E}+02$ & $1.82 \mathrm{E}+03$ & $1.21 \mathrm{E}+02$ & $1.07 E+02$ & $1.67 \mathrm{E}+00$ & $1.45 \mathrm{E}-02$ & $3.50 \mathrm{E}+05$ & $2.01 E+00$ \\
\hline $1.30 \mathrm{E}+02$ & $3.39 \mathrm{E}+02$ & $3.02 \mathrm{E}+02$ & $1.79 \mathrm{E}+00$ & $3.88 \mathrm{E}+02$ & $1.97 \mathrm{E}+03$ & $1.39 \mathrm{E}+02$ & $1.24 \mathrm{E}+02$ & $1.47 \mathrm{E}+00$ & $1.45 \mathrm{E}-02$ & $3.48 \mathrm{E}+05$ & $2.00 \mathrm{E}+00$ \\
\hline $1.40 \mathrm{E}+02$ & $3.42 \mathrm{E}+02$ & $3.02 \mathrm{E}+02$ & $1.67 \mathrm{E}+00$ & $4.05 \mathrm{E}+02$ & $2.05 E+03$ & $1.56 \mathrm{E}+02$ & $1.41 \mathrm{E}+02$ & $1.37 \mathrm{E}+00$ & $1.44 \mathrm{E}-02$ & $3.47 \mathrm{E}+05$ & $2.00 \mathrm{E}+00$ \\
\hline $1.50 \mathrm{E}+02$ & $3.45 \mathrm{E}+02$ & $3.02 E+02$ & $1.56 \mathrm{E}+00$ & $4.21 \mathrm{E}+02$ & $2.06 \mathrm{E}+03$ & $1.73 \mathrm{E}+02$ & $1.57 \mathrm{E}+02$ & $1.28 \mathrm{E}+00$ & $1.43 \mathrm{E}-02$ & $3.45 \mathrm{E}+05$ & $1.99 \mathrm{E}+00$ \\
\hline $1.60 \mathrm{E}+02$ & $3.48 \mathrm{E}+02$ & $3.02 E+02$ & $1.45 \mathrm{E}+00$ & $4.36 \mathrm{E}+02$ & $2.03 E+03$ & $1.90 \mathrm{E}+02$ & $1.73 \mathrm{E}+02$ & $1.20 \mathrm{E}+00$ & $1.42 \mathrm{E}-02$ & $3.43 \mathrm{E}+05$ & $1.99 \mathrm{E}+00$ \\
\hline $1.70 \mathrm{E}+02$ & $3.50 \mathrm{E}+02$ & $3.02 \mathrm{E}+02$ & $1.34 \mathrm{E}+00$ & $4.51 \mathrm{E}+02$ & $1.96 \mathrm{E}+03$ & $2.06 \mathrm{E}+02$ & $1.88 \mathrm{E}+02$ & $1.11 \mathrm{E}+00$ & $1.42 \mathrm{E}-02$ & $3.42 \mathrm{E}+05$ & $1.99 \mathrm{E}+00$ \\
\hline $1.80 \mathrm{E}+02$ & $3.52 \mathrm{E}+02$ & $3.02 \mathrm{E}+02$ & $1.24 \mathrm{E}+00$ & $4.64 \mathrm{E}+02$ & $1.88 \mathrm{E}+03$ & $2.22 \mathrm{E}+02$ & $2.03 \mathrm{E}+02$ & $1.04 \mathrm{E}+00$ & $1.41 \mathrm{E}-02$ & $3.40 \mathrm{E}+05$ & $1.98 \mathrm{E}+00$ \\
\hline $1.90 \mathrm{E}+02$ & $3.54 \mathrm{E}+02$ & $3.02 \mathrm{E}+02$ & $1.15 \mathrm{E}+00$ & $4.77 \mathrm{E}+02$ & $1.74 \mathrm{E}+03$ & $2.35 \mathrm{E}+02$ & $2.17 \mathrm{E}+02$ & $9.24 \mathrm{E}-01$ & $1.31 \mathrm{E}-02$ & $3.17 \mathrm{E}+05$ & $1.92 \mathrm{E}+00$ \\
\hline $2.00 \mathrm{E}+02$ & $3.55 \mathrm{E}+02$ & $3.02 \mathrm{E}+02$ & $1.07 \mathrm{E}+00$ & $4.89 \mathrm{E}+02$ & $1.52 \mathrm{E}+03$ & $2.46 \mathrm{E}+02$ & $2.28 \mathrm{E}+02$ & $8.23 \mathrm{E}-01$ & $1.22 \mathrm{E}-02$ & $2.93 \mathrm{E}+05$ & $1.85 \mathrm{E}+00$ \\
\hline $2.10 \mathrm{E}+02$ & $3.56 \mathrm{E}+02$ & $3.01 \mathrm{E}+02$ & $9.94 \mathrm{E}-01$ & $4.99 \mathrm{E}+02$ & $1.25 \mathrm{E}+03$ & $2.55 \mathrm{E}+02$ & $2.36 \mathrm{E}+02$ & $7.31 \mathrm{E}-01$ & $1.12 \mathrm{E}-02$ & $2.70 \mathrm{E}+05$ & $1.79 \mathrm{E}+00$ \\
\hline $2.20 \mathrm{E}+02$ & $3.57 \mathrm{E}+02$ & $3.01 \mathrm{E}+02$ & $9.28 \mathrm{E}-01$ & $5.08 \mathrm{E}+02$ & $9.68 \mathrm{E}+02$ & $2.62 \mathrm{E}+02$ & $2.43 \mathrm{E}+02$ & $6.48 \mathrm{E}-01$ & $1.02 \mathrm{E}-02$ & $2.47 \mathrm{E}+05$ & $1.71 \mathrm{E}+00$ \\
\hline $2.30 \mathrm{E}+02$ & $3.57 \mathrm{E}+02$ & $3.01 \mathrm{E}+02$ & $8.70 \mathrm{E}-01$ & $5.16 \mathrm{E}+02$ & $6.82 \mathrm{E}+02$ & $2.66 \mathrm{E}+02$ & $2.47 \mathrm{E}+02$ & $5.74 \mathrm{E}-01$ & $9.27 \mathrm{E}-03$ & $2.23 \mathrm{E}+05$ & $1.64 \mathrm{E}+00$ \\
\hline $2.40 \mathrm{E}+02$ & $3.57 \mathrm{E}+02$ & $3.01 \mathrm{E}+02$ & $8.20 \mathrm{E}-01$ & $5.23 \mathrm{E}+02$ & $4.17 \mathrm{E}+02$ & $2.69 \mathrm{E}+02$ & $2.50 \mathrm{E}+02$ & $5.07 \mathrm{E}-01$ & $8.30 \mathrm{E}-03$ & $2.00 \mathrm{E}+05$ & $1.56 \mathrm{E}+00$ \\
\hline $2.50 \mathrm{E}+02$ & $3.57 \mathrm{E}+02$ & $3.01 E+02$ & $7.78 \mathrm{E}-01$ & $5.29 \mathrm{E}+02$ & $2.21 \mathrm{E}+02$ & $2.71 \mathrm{E}+02$ & $2.52 \mathrm{E}+02$ & $4.70 \mathrm{E}-01$ & $7.95 \mathrm{E}-03$ & $1.92 \mathrm{E}+05$ & $1.53 \mathrm{E}+00$ \\
\hline $2.60 \mathrm{E}+02$ & $3.57 \mathrm{E}+02$ & $3.01 \mathrm{E}+02$ & $7.41 \mathrm{E}-01$ & $5.34 \mathrm{E}+02$ & $1.09 \mathrm{E}+02$ & $2.72 \mathrm{E}+02$ & $2.54 \mathrm{E}+02$ & $4.38 \mathrm{E}-01$ & $7.61 \mathrm{E}-03$ & $1.83 \mathrm{E}+05$ & $1.49 \mathrm{E}+00$ \\
\hline $2.70 \mathrm{E}+02$ & $3.57 \mathrm{E}+02$ & $3.01 \mathrm{E}+02$ & $7.09 \mathrm{E}-01$ & $5.38 \mathrm{E}+02$ & $5.17 \mathrm{E}+01$ & $2.74 \mathrm{E}+02$ & $2.56 \mathrm{E}+02$ & $4.08 \mathrm{E}-01$ & $7.26 \mathrm{E}-03$ & $1.75 \mathrm{E}+05$ & $1.46 \mathrm{E}+00$ \\
\hline $2.80 \mathrm{E}+02$ & $3.56 \mathrm{E}+02$ & $3.01 \mathrm{E}+02$ & $6.80 \mathrm{E}-01$ & $5.42 \mathrm{E}+02$ & $2.38 \mathrm{E}+01$ & $2.75 \mathrm{E}+02$ & $2.57 \mathrm{E}+02$ & $3.81 \mathrm{E}-01$ & $6.92 \mathrm{E}-03$ & $1.67 \mathrm{E}+05$ & $1.43 \mathrm{E}+00$ \\
\hline $2.90 \mathrm{E}+02$ & $3.56 \mathrm{E}+02$ & $3.01 \mathrm{E}+02$ & $6.55 \mathrm{E}-01$ & $5.46 \mathrm{E}+02$ & $9.16 \mathrm{E}+00$ & $2.75 \mathrm{E}+02$ & $2.57 \mathrm{E}+02$ & $3.56 \mathrm{E}-01$ & $6.57 \mathrm{E}-03$ & $1.58 \mathrm{E}+05$ & $1.39 \mathrm{E}+00$ \\
\hline $3.00 \mathrm{E}+02$ & $3.56 \mathrm{E}+02$ & $3.01 E+02$ & $6.32 \mathrm{E}-01$ & $5.49 \mathrm{E}+02$ & $1.81 \mathrm{E}+00$ & $2.75 \mathrm{E}+02$ & $2.57 \mathrm{E}+02$ & $\mathrm{E}-01$ & $6.22 \mathrm{E}-03$ & $1.50 \mathrm{E}+05$ & $1.36 \mathrm{E}+00$ \\
\hline $3.10 \mathrm{E}+02$ & $3.56 \mathrm{E}+02$ & $3.01 \mathrm{E}+02$ & $6.12 \mathrm{E}-01$ & $5.52 \mathrm{E}+02$ & $-3.77 \mathrm{E}-02$ & $2.74 \mathrm{E}+02$ & $2.57 \mathrm{E}+02$ & $3.12 \mathrm{E}-01$ & $5.88 \mathrm{E}-03$ & $1.42 \mathrm{E}+05$ & $1.32 \mathrm{E}+00$ \\
\hline $3.20 \mathrm{E}+02$ & $3.55 \mathrm{E}+02$ & $3.01 \mathrm{E}+02$ & $5.95 \mathrm{E}-01$ & $5.54 \mathrm{E}+02$ & $-1.98 \mathrm{E}+00$ & $2.73 \mathrm{E}+02$ & $2.56 \mathrm{E}+02$ & $E-01$ & $5.53 \mathrm{E}-03$ & $1.33 \mathrm{E}+05$ & $1.28 \mathrm{E}+00$ \\
\hline $3.30 \mathrm{E}+02$ & $3.55 \mathrm{E}+02$ & $3.01 \mathrm{E}+02$ & $5.79 \mathrm{E}-01$ & $5.56 \mathrm{E}+02$ & $-6.68 \mathrm{E}+00$ & $2.71 \mathrm{E}+02$ & $2.54 \mathrm{E}+02$ & $2.74 \mathrm{E}-01$ & $5.19 \mathrm{E}-03$ & $1.25 \mathrm{E}+05$ & $1.24 \mathrm{E}+00$ \\
\hline $3.40 \mathrm{E}+02$ & $3.54 \mathrm{E}+02$ & $3.01 \mathrm{E}+02$ & $5.66 \mathrm{E}-01$ & $5.58 \mathrm{E}+02$ & +01 & $2.69 \mathrm{E}+02$ & $2.52 \mathrm{E}+02$ & $E-01$ & $4.84 \mathrm{E}-03$ & $1.17 \mathrm{E}+05$ & $1.20 \mathrm{E}+00$ \\
\hline $3.50 \mathrm{E}+02$ & $3.54 \mathrm{E}+02$ & $3.01 E+02$ & $5.54 \mathrm{E}-01$ & $5.60 \mathrm{E}+02$ & $-2.33 \mathrm{E}+01$ & $2.66 \mathrm{E}+02$ & $2.49 \mathrm{E}+02$ & $2.40 \mathrm{E}-01$ & $4.50 \mathrm{E}-03$ & $1.08 \mathrm{E}+05$ & $1.15 \mathrm{E}+00$ \\
\hline $3.60 \mathrm{E}+02$ & $3.53 \mathrm{E}+02$ & $3.01 \mathrm{E}+02$ & $5.44 \mathrm{E}-01$ & $5.61 \mathrm{E}+02$ & $-3.48 \mathrm{E}+01$ & $2.63 \mathrm{E}+02$ & $2.45 \mathrm{E}+02$ & $\mathrm{E}-01$ & $4.15 \mathrm{E}-03$ & $1.00 \mathrm{E}+05$ & $1.11 \mathrm{E}+00$ \\
\hline $3.70 \mathrm{E}+02$ & $3.52 \mathrm{E}+02$ & $3.01 \mathrm{E}+02$ & $5.35 \mathrm{E}-01$ & $5.62 \mathrm{E}+02$ & $-3.73 \mathrm{E}+01$ & $2.59 \mathrm{E}+02$ & $2.42 \mathrm{E}+02$ & $2.21 \mathrm{E}-01$ & $4.15 \mathrm{E}-03$ & $1.00 \mathrm{E}+05$ & $1.11 \mathrm{E}+00$ \\
\hline $3.80 \mathrm{E}+02$ & $3.52 \mathrm{E}+02$ & $3.01 \mathrm{E}+02$ & $\mathrm{E}-01$ & $5.63 \mathrm{E}+02$ & $-3.37 \mathrm{E}+01$ & $2.56 \mathrm{E}+02$ & $2.39 \mathrm{E}+02$ & $18 \mathrm{E}-01$ & $4.15 \mathrm{E}-03$ & $1.00 \mathrm{E}+05$ & $1.11 \mathrm{E}+00$ \\
\hline $3.90 \mathrm{E}+02$ & $3.51 \mathrm{E}+02$ & $3.01 \mathrm{E}+02$ & $5.18 \mathrm{E}-01$ & $5.65 \mathrm{E}+02$ & $-2.97 \mathrm{E}+01$ & $2.53 \mathrm{E}+02$ & $2.36 \mathrm{E}+02$ & $2.15 \mathrm{E}-01$ & $4.15 \mathrm{E}-03$ & $1.00 \mathrm{E}+05$ & $1.11 \mathrm{E}+00$ \\
\hline $4.00 \mathrm{E}+02$ & $3.51 \mathrm{E}+02$ & $3.01 E+02$ & $5.09 \mathrm{E}-01$ & $5.66 \mathrm{E}+02$ & & $2.51 \mathrm{E}+02$ & $2.33 \mathrm{E}+02$ & $2.12 \mathrm{E}-01$ & $4.15 \mathrm{E}-03$ & $1.00 \mathrm{E}+05$ & $1.11 \mathrm{E}+00$ \\
\hline $4.10 \mathrm{E}+02$ & $3.50 \mathrm{E}+02$ & $3.01 \mathrm{E}+02$ & $5.01 \mathrm{E}-01$ & $5.67 \mathrm{E}+02$ & $-2.27 \mathrm{E}+01$ & $2.48 \mathrm{E}+02$ & $2.31 \mathrm{E}+02$ & $2.08 \mathrm{E}-01$ & $4.15 \mathrm{E}-03$ & $1.00 \mathrm{E}+05$ & $1.11 \mathrm{E}+00$ \\
\hline $4.20 \mathrm{E}+02$ & $3.49 \mathrm{E}+02$ & $3.01 \mathrm{E}+02$ & $\mathrm{E}-01$ & $5.68 \mathrm{E}+02$ & $-1.99 \mathrm{E}+01$ & $2.46 \mathrm{E}+02$ & $2.28 \mathrm{E}+02$ & $2.05 \mathrm{E}-01$ & $4.15 \mathrm{E}-03$ & $1.00 \mathrm{E}+05$ & $1.11 \mathrm{E}+00$ \\
\hline $4.30 \mathrm{E}+02$ & $3.49 \mathrm{E}+02$ & $3.01 \mathrm{E}+02$ & $4.83 \mathrm{E}-01$ & $5.69 \mathrm{E}+02$ & $-2.09 \mathrm{E}+01$ & $2.43 \mathrm{E}+02$ & $2.26 \mathrm{E}+02$ & $1.97 \mathrm{E}-01$ & $4.01 \mathrm{E}-03$ & $9.67 \mathrm{E}+04$ & $1.09 \mathrm{E}+00$ \\
\hline $4.40 \mathrm{E}+02$ & $3.48 \mathrm{E}+02$ & $3.01 \mathrm{E}+02$ & -01 & & $-2.36 \mathrm{E}+01$ & $2.41 \mathrm{E}+02$ & $2.23 \mathrm{E}+02$ & $1.90 \mathrm{E}-01$ & $3.87 \mathrm{E}-03$ & $9.33 \mathrm{E}+04$ & $1.07 \mathrm{E}+00$ \\
\hline $4.50 \mathrm{E}+02$ & $3.48 \mathrm{E}+02$ & $3.02 \mathrm{E}+02$ & $4.68 \mathrm{E}-01$ & $5.72 \mathrm{E}+02$ & $-2.66 \mathrm{E}+01$ & $2.38 \mathrm{E}+02$ & $2.21 \mathrm{E}+02$ & $1.83 \mathrm{E}-01$ & $3.73 \mathrm{E}-03$ & $9.00 \mathrm{E}+04$ & $1.05 \mathrm{E}+00$ \\
\hline $4.60 \mathrm{E}+02$ & $3.47 \mathrm{E}+02$ & $3.02 \mathrm{E}+02$ & $4.61 \mathrm{E}-01$ & $5.73 \mathrm{E}+02$ & $-2.98 \mathrm{E}+01$ & $2.35 \mathrm{E}+02$ & $2.18 \mathrm{E}+02$ & $1.76 \mathrm{E}-01$ & $3.60 \mathrm{E}-03$ & $8.67 \mathrm{E}+04$ & $1.03 \mathrm{E}+00$ \\
\hline $4.70 \mathrm{E}+02$ & $3.47 \mathrm{E}+02$ & $3.02 \mathrm{E}+02$ & $4.55 \mathrm{E}-01$ & $5.73 \mathrm{E}+02$ & $-3.30 \mathrm{E}+01$ & $2.33 \mathrm{E}+02$ & $2.15 \mathrm{E}+02$ & $1.70 \mathrm{E}-01$ & $3.46 \mathrm{E}-03$ & $8.33 \mathrm{E}+04$ & $1.01 \mathrm{E}+00$ \\
\hline $4.80 \mathrm{E}+02$ & $3.46 \mathrm{E}+02$ & $3.02 \mathrm{E}+02$ & $4.50 \mathrm{E}-01$ & $5.74 \mathrm{E}+02$ & $-3.63 \mathrm{E}+01$ & $2.30 \mathrm{E}+02$ & $2.12 \mathrm{E}+02$ & $1.64 \mathrm{E}-01$ & $3.32 \mathrm{E}-03$ & $8.00 \mathrm{E}+04$ & $9.86 \mathrm{E}-01$ \\
\hline $4.90 \mathrm{E}+02$ & $3.46 \mathrm{E}+02$ & $3.02 \mathrm{E}+02$ & $4.45 \mathrm{E}-01$ & $5.75 \mathrm{E}+02$ & $-3.65 \mathrm{E}+01$ & $2.27 \mathrm{E}+02$ & $2.09 \mathrm{E}+02$ & $1.61 \mathrm{E}-01$ & $3.28 \mathrm{E}-03$ & $7.92 \mathrm{E}+04$ & $9.81 \mathrm{E}-01$ \\
\hline $5.00 \mathrm{E}+02$ & $3.45 \mathrm{E}+02$ & $3.02 \mathrm{E}+02$ & $4.40 \mathrm{E}-01$ & $5.75 \mathrm{E}+02$ & $-3.48 \mathrm{E}+01$ & $2.24 \mathrm{E}+02$ & $2.07 \mathrm{E}+02$ & $1.58 \mathrm{E}-01$ & $3.25 \mathrm{E}-03$ & $7.83 \mathrm{E}+04$ & $9.75 \mathrm{E}-01$ \\
\hline $5.10 \mathrm{E}+02$ & $3.45 \mathrm{E}+02$ & $3.02 \mathrm{E}+02$ & $4.35 \mathrm{E}-01$ & $5.76 \mathrm{E}+02$ & $-3.30 \mathrm{E}+01$ & $2.21 \mathrm{E}+02$ & $2.04 \mathrm{E}+02$ & $1.56 \mathrm{E}-01$ & $3.22 \mathrm{E}-03$ & $7.75 \mathrm{E}+04$ & $9.70 \mathrm{E}-01$ \\
\hline $5.20 \mathrm{E}+02$ & $3.44 \mathrm{E}+02$ & $3.02 \mathrm{E}+02$ & $4.30 \mathrm{E}-01$ & $5.77 \mathrm{E}+02$ & $-3.13 \mathrm{E}+01$ & $2.19 \mathrm{E}+02$ & $2.01 \mathrm{E}+02$ & $1.53 \mathrm{E}-01$ & $3.18 \mathrm{E}-03$ & $7.67 \mathrm{E}+04$ & $9.64 \mathrm{E}-01$ \\
\hline $5.30 \mathrm{E}+02$ & $3.44 \mathrm{E}+02$ & $3.02 \mathrm{E}+02$ & $4.25 \mathrm{E}-01$ & & $-2.98 \mathrm{E}+01$ & $2.16 \mathrm{E}+02$ & $1.99 \mathrm{E}+02$ & $1.51 \mathrm{E}-01$ & $3.15 \mathrm{E}-03$ & $7.58 \mathrm{E}+04$ & $9.59 \mathrm{E}-01$ \\
\hline $5.40 \mathrm{E}+02$ & $3.43 \mathrm{E}+02$ & $3.02 \mathrm{E}+02$ & $4.20 \mathrm{E}-01$ & $5.78 \mathrm{E}+02$ & $-2.84 \mathrm{E}+01$ & $2.14 \mathrm{E}+02$ & $1.97 \mathrm{E}+02$ & $1.48 \mathrm{E}-01$ & $3.11 \mathrm{E}-03$ & $7.50 \mathrm{E}+04$ & $9.53 \mathrm{E}-01$ \\
\hline $5.50 \mathrm{E}+02$ & $3.43 \mathrm{E}+02$ & $3.02 \mathrm{E}+02$ & $4.15 \mathrm{E}-01$ & & $-2.14 \mathrm{E}+01$ & $2.12 \mathrm{E}+02$ & & $1.51 \mathrm{E}-01$ & $3.28 \mathrm{E}-03$ & $7.92 \mathrm{E}+04$ & $9.81 \mathrm{E}-01$ \\
\hline $5.60 \mathrm{E}+02$ & $3.42 \mathrm{E}+02$ & $3.02 \mathrm{E}+02$ & $4.09 \mathrm{E}-01$ & $5.80 \mathrm{E}+02$ & $-1.28 \mathrm{E}+01$ & $2.10 \mathrm{E}+02$ & $1.93 \mathrm{E}+02$ & $1.54 \mathrm{E}-01$ & $3.46 \mathrm{E}-03$ & $8.33 \mathrm{E}+04$ & $1.01 \mathrm{E}+00$ \\
\hline $5.70 \mathrm{E}+02$ & $3.42 \mathrm{E}+02$ & $3.02 \mathrm{E}+$ & $4.02 \mathrm{E}-01$ & & $-6.47 \mathrm{E}+00$ & $2.09 \mathrm{E}+02$ & & $1.58 \mathrm{E}-01$ & $3.63 \mathrm{E}-03$ & $8.75 \mathrm{E}+04$ & $1.03 \mathrm{E}+00$ \\
\hline $5.80 \mathrm{E}+02$ & $3.42 \mathrm{E}+02$ & $3.02 \mathrm{E}+02$ & $3.94 \mathrm{E}-01$ & $5.82 \mathrm{E}+02$ & $-2.39 \mathrm{E}+00$ & $2.08 \mathrm{E}+02$ & $1.90 \mathrm{E}+02$ & 1.62E-01 & $3.80 \mathrm{E}-03$ & $9.17 \mathrm{E}+04$ & $1.06 \mathrm{E}+00$ \\
\hline $5.90 \mathrm{E}+02$ & $3.42 \mathrm{E}+02$ & $3.02 \mathrm{E}+02$ & $3.85 \mathrm{E}-01$ & $5.83 \mathrm{E}+02$ & $-3.53 \mathrm{E}-01$ & $2.07 \mathrm{E}+02$ & $1.89 \mathrm{E}+02$ & $1.66 \mathrm{E}-01$ & $3.98 \mathrm{E}-03$ & $9.58 \mathrm{E}+04$ & $1.08 \mathrm{E}+00$ \\
\hline
\end{tabular}


WSRC-TR-2001-00405

\begin{tabular}{|c|c|c|c|c|c|c|c|c|c|c|c|}
\hline TIME & \begin{tabular}{|c|} 
Main \\
Convec. Size
\end{tabular} & \begin{tabular}{|c|} 
Target \\
Temperature \\
(1) \\
\end{tabular} & $\begin{array}{l}\text { Target Flux } \\
\text { (1) }\end{array}$ & $\begin{array}{c}\text { Target Fire } \\
\text { Rad. (1) }\end{array}$ & $\begin{array}{c}\text { Target } \\
\text { Surface Rad. } \\
\text { (1) }\end{array}$ & $\begin{array}{c}\text { Target Gas } \\
\text { Rad. (1) }\end{array}$ & $\begin{array}{c}\text { Target } \\
\text { Convec. (1) }\end{array}$ & \begin{tabular}{|c|} 
Target \\
Temperature \\
(2) \\
\end{tabular} & $\begin{array}{l}\text { Target Flux } \\
\text { (2) }\end{array}$ & $\begin{array}{c}\text { Target Fire } \\
\text { Rad. (2) }\end{array}$ & $\begin{array}{c}\text { Target } \\
\text { Surface Rad. } \\
\text { (2) }\end{array}$ \\
\hline $0.00 \mathrm{E}+00$ & $0.00 \mathrm{E}+00$ & $3.00 \mathrm{E}+02$ & $0.00 \mathrm{E}+00$ & $0.00 \mathrm{E}+00$ & $0.00 \mathrm{E}+00$ & $0.00 \mathrm{E}+00$ & $0.00 \mathrm{E}+00$ & $3.00 \mathrm{E}+02$ & $4.59 \mathrm{E}+02$ & $0.00 \mathrm{E}+00$ & $9.61 \mathrm{E}+01$ \\
\hline $1.00 \mathrm{E}+01$ & $33 \mathrm{E}+04$ & $3.00 \mathrm{E}+02$ & $5.28 \mathrm{E}+02$ & $1.28 \mathrm{E}+01$ & $8.31 \mathrm{E}+01$ & $4.29 \mathrm{E}+00$ & $-1.79 \mathrm{E}-01$ & $3.00 \mathrm{E}+02$ & $4.61 \mathrm{E}+02$ & $.00 \mathrm{E}+00$ & $9.30 \mathrm{E}+01$ \\
\hline $2.00 \mathrm{E}+01$ & $7 \mathrm{E}+04$ & $3.01 \mathrm{E}+02$ & $5.95 \mathrm{E}+02$ & $2.27 \mathrm{E}+01$ & $7.40 \mathrm{E}+01$ & $3.78 \mathrm{E}+00$ & $-4.30 \mathrm{E}-01$ & $3.00 \mathrm{E}+02$ & $4.65 \mathrm{E}+02$ & $0 \mathrm{E}+00$ & $8.88 \mathrm{E}+01$ \\
\hline $3.00 \mathrm{E}+01$ & $0 \mathrm{E}+04$ & $2 \mathrm{E}+02$ & $63 \mathrm{E}+02$ & $3.06 \mathrm{E}+01$ & $67 \mathrm{E}+01$ & $38 \mathrm{E}+00$ & $-6.60 \mathrm{E}-01$ & $.00 \mathrm{E}+02$ & $.69 \mathrm{E}+02$ & $00 \mathrm{E}+00$ & $8.44 \mathrm{E}+01$ \\
\hline $4.00 \mathrm{E}+01$ & $E+04$ & $03 \mathrm{E}+02$ & $30 \mathrm{E}+02$ & $E+01$ & $8 \mathrm{E}+01$ & $05 \mathrm{E}+00$ & $-8.69 \mathrm{E}-01$ & $00 \mathrm{E}+02$ & $.75 \mathrm{E}+02$ & $0 \mathrm{E}+00$ & +01 \\
\hline $5.00 \mathrm{E}+01$ & +05 & $04 \mathrm{E}+02$ & $98 \mathrm{E}+02$ & $E+01$ & $0 \mathrm{E}+01$ & $2.79 \mathrm{E}+00$ & $-1.06 \mathrm{E}+00$ & $00 \mathrm{E}+02$ & $4.83 \mathrm{E}+02$ & $0 \mathrm{E}+00$ & $7.54 \mathrm{E}+01$ \\
\hline $6.00 \mathrm{E}+01$ & $40 \mathrm{E}+05$ & $05 \mathrm{E}+02$ & $8.65 \mathrm{E}+02$ & $4.68 \mathrm{E}+01$ & $18 \mathrm{E}+01$ & $2.56 \mathrm{E}+00$ & $-1.23 \mathrm{E}+00$ & $3.01 \mathrm{E}+02$ & $4.92 \mathrm{E}+02$ & $00 \mathrm{E}+00$ & $7.11 \mathrm{E}+01$ \\
\hline $7.00 \mathrm{E}+01$ & $57 \mathrm{E}+05$ & $3.06 \mathrm{E}+02$ & $15 \mathrm{E}+02$ & $4.98 \mathrm{E}+01$ & $.92 \mathrm{E}+01$ & $2.41 \mathrm{E}+00$ & $-1.39 \mathrm{E}+00$ & $3.01 \mathrm{E}+02$ & $5.02 \mathrm{E}+02$ & $.00 \mathrm{E}+00$ & $6.69 \mathrm{E}+01$ \\
\hline $8.00 \mathrm{E}+01$ & $.75 E+05$ & $3.07 \mathrm{E}+02$ & $9.64 \mathrm{E}+02$ & $5.25 \mathrm{E}+01$ & $4.69 \mathrm{E}+01$ & $2.28 \mathrm{E}+00$ & $-1.62 \mathrm{E}+00$ & $3.01 \mathrm{E}+02$ & $5.14 \mathrm{E}+02$ & $.00 \mathrm{E}+00$ & $6.30 \mathrm{E}+01$ \\
\hline $9.00 \mathrm{E}+01$ & $1.92 \mathrm{E}+05$ & $3.08 \mathrm{E}+02$ & $1.01 \mathrm{E}+03$ & $5.49 \mathrm{E}+01$ & $4.48 \mathrm{E}+01$ & $2.16 \mathrm{E}+00$ & $-1.85 \mathrm{E}+00$ & $3.01 \mathrm{E}+02$ & $5.27 \mathrm{E}+02$ & $.00 \mathrm{E}+00$ & $5.92 \mathrm{E}+01$ \\
\hline $1.00 \mathrm{E}+02$ & $0 \mathrm{E}+05$ & $3.10 \mathrm{E}+02$ & $1.16 \mathrm{E}+03$ & $5.05 \mathrm{E}+01$ & $3.62 \mathrm{E}+01$ & $6.02 \mathrm{E}+00$ & $7.31 \mathrm{E}+00$ & $3.01 \mathrm{E}+02$ & $5.42 \mathrm{E}+02$ & $00 \mathrm{E}+00$ & $5.57 \mathrm{E}+01$ \\
\hline $1.10 \mathrm{E}+02$ & $27 \mathrm{E}+05$ & $3.11 \mathrm{E}+02$ & $1.20 \mathrm{E}+03$ & $4.80 \mathrm{E}+01$ & $2.86 \mathrm{E}+01$ & $1.54 \mathrm{E}+01$ & $7.98 \mathrm{E}+00$ & $3.01 \mathrm{E}+02$ & $5.58 \mathrm{E}+02$ & $00 \mathrm{E}+00$ & $5.24 \mathrm{E}+01$ \\
\hline & & & & & - & & & & 02 & +00 & \\
\hline $1.30 \mathrm{E}+02$ & +05 & +02 & & $E+01$ & $E+01$ & $E+01$ & +00 & $3.02 \mathrm{E}+02$ & $.94 \mathrm{E}+02$ & +00 & \\
\hline+02 & +05 & $15 \mathrm{E}+02$ & +03 & $3.86 \mathrm{E}+01$ & $90 \mathrm{E}+01$ & $3.15 \mathrm{E}+01$ & +01 & $3.02 \mathrm{E}+02$ & $6.11 \mathrm{E}+02$ & $E+00$ & +01 \\
\hline$E+02$ & $11 \mathrm{E}+05$ & $16 \mathrm{E}+02$ & $1.24 \mathrm{E}+03$ & $3.56 \mathrm{E}+01$ & $72 \mathrm{E}+01$ & $3.53 \mathrm{E}+01$ & $1.19 \mathrm{E}+01$ & $3.02 \mathrm{E}+02$ & $6.28 \mathrm{E}+02$ & $E+00$ & $4.14 \mathrm{E}+01$ \\
\hline $1.60 \mathrm{E}+02$ & $10 \mathrm{E}+05$ & $3.16 \mathrm{E}+02$ & $1.24 \mathrm{E}+03$ & $3.29 \mathrm{E}+01$ & $1.58 \mathrm{E}+01$ & $3.87 \mathrm{E}+01$ & $1.26 \mathrm{E}+01$ & $3.02 \mathrm{E}+02$ & $6.44 \mathrm{E}+02$ & $0 \mathrm{E}+00$ & $3.92 \mathrm{E}+01$ \\
\hline $1.70 \mathrm{E}+02$ & $39 \mathrm{E}+05$ & $3.17 \mathrm{E}+02$ & $1.25 \mathrm{E}+03$ & $3.05 \mathrm{E}+01$ & $1.45 \mathrm{E}+01$ & $4.17 \mathrm{E}+01$ & $1.33 \mathrm{E}+01$ & $3.02 \mathrm{E}+02$ & $6.60 \mathrm{E}+02$ & $.00 \mathrm{E}+00$ & $3.73 \mathrm{E}+01$ \\
\hline $1.80 \mathrm{E}+02$ & $2.38 \mathrm{E}+05$ & $3.18 \mathrm{E}+02$ & $1.26 \mathrm{E}+03$ & $2.83 \mathrm{E}+01$ & $1.35 \mathrm{E}+01$ & $4.43 \mathrm{E}+01$ & $1.38 \mathrm{E}+01$ & $3.02 E+02$ & $6.75 \mathrm{E}+02$ & $.00 \mathrm{E}+00$ & $3.55 \mathrm{E}+01$ \\
\hline $1.90 \mathrm{E}+02$ & $2 \mathrm{E}+05$ & $3.19 \mathrm{E}+02$ & $1.24 \mathrm{E}+03$ & $2.52 \mathrm{E}+01$ & $1.28 \mathrm{E}+01$ & $4.74 \mathrm{E}+01$ & $1.46 \mathrm{E}+01$ & $3.02 E+02$ & $6.89 \mathrm{E}+02$ & $E+00$ & $E+01$ \\
\hline $2.00 \mathrm{E}+02$ & $5 \mathrm{E}+05$ & $3.19 \mathrm{E}+02$ & $1.22 \mathrm{E}+03$ & $2.25 \mathrm{E}+01$ & $1.22 \mathrm{E}+01$ & $5.02 \mathrm{E}+01$ & $1.51 \mathrm{E}+01$ & $3.02 \mathrm{E}+02$ & $7.00 \mathrm{E}+02$ & $\mathrm{E}+00$ & $3.25 E+01$ \\
\hline $2.10 \mathrm{E}+02$ & $1.89 \mathrm{E}+05$ & $3.20 \mathrm{E}+02$ & $1.21 \mathrm{E}+03$ & $2.00 \mathrm{E}+01$ & $1.17 \mathrm{E}+01$ & $5.27 \mathrm{E}+01$ & $1.56 \mathrm{E}+01$ & & & $\mathrm{DE}+00$ & \\
\hline $2.20 \mathrm{E}+02$ & $1.73 \mathrm{E}+05$ & $3.20 \mathrm{E}+02$ & $1.19 \mathrm{E}+03$ & $1.78 \mathrm{E}+01$ & $14 \mathrm{E}+01$ & $5.49 \mathrm{E}+01$ & $1.59 \mathrm{E}+01$ & $02 \mathrm{E}+02$ & $\mathrm{E}+02$ & $\mathrm{E}+00$ & $3.05 \mathrm{E}+01$ \\
\hline $2.30 \mathrm{E}+02$ & $66 \mathrm{E}+05$ & $20 \mathrm{E}+02$ & & $1.58 \mathrm{E}+01$ & $E+01$ & $E+01$ & $62 \mathrm{E}+01$ & +02 & $E+02$ & $E+00$ & $E+01$ \\
\hline+02 & $E+05$ & $E+02$ & +03 & $1.40 \mathrm{E}+01$ & +01 & $E+01$ & $1.63 \mathrm{E}+01$ & $3.02 \mathrm{E}+02$ & $7.22 \mathrm{E}+02$ & $E+00$ & \\
\hline+02 & +05 & $3.21 \mathrm{E}+02$ & +03 & $1.31 \mathrm{E}+01$ & $E+01$ & $5.99 \mathrm{E}+01$ & $1.63 \mathrm{E}+01$ & $3.02 E+02$ & $7.24 \mathrm{E}+02$ & $E+00$ & $E+01$ \\
\hline $2.60 \mathrm{E}+02$ & $1.28 \mathrm{E}+05$ & $3.21 \mathrm{E}+02$ & $1.13 \mathrm{E}+03$ & $1.24 \mathrm{E}+01$ & $1.05 \mathrm{E}+01$ & $6.09 \mathrm{E}+01$ & $1.62 \mathrm{E}+01$ & $3.02 \mathrm{E}+02$ & $7.26 \mathrm{E}+02$ & $\mathrm{E}+00$ & $2.82 E+01$ \\
\hline $2.70 \mathrm{E}+02$ & $1.22 \mathrm{E}+05$ & $3.21 \mathrm{E}+02$ & $1.12 \mathrm{E}+03$ & $1.17 \mathrm{E}+01$ & $1.04 \mathrm{E}+01$ & $6.18 \mathrm{E}+01$ & $1.62 \mathrm{E}+01$ & $3.02 \mathrm{E}+02$ & $7.28 \mathrm{E}+02$ & $E+00$ & $2.79 \mathrm{E}+01$ \\
\hline $2.80 \mathrm{E}+02$ & $1.17 \mathrm{E}+05$ & $3.21 \mathrm{E}+02$ & $1.11 \mathrm{E}+03$ & $1.10 \mathrm{E}+01$ & $1.03 \mathrm{E}+01$ & $6.26 \mathrm{E}+01$ & $1.61 \mathrm{E}+01$ & $3.02 \mathrm{E}+02$ & $7.29 \mathrm{E}+02$ & $00 \mathrm{E}+00$ & $2.76 \mathrm{E}+01$ \\
\hline $2.90 \mathrm{E}+02$ & $1.11 \mathrm{E}+05$ & $3.22 \mathrm{E}+02$ & $1.10 \mathrm{E}+03$ & $1.04 \mathrm{E}+01$ & $1.02 \mathrm{E}+01$ & $6.34 \mathrm{E}+01$ & $1.60 \mathrm{E}+01$ & $3.02 \mathrm{E}+02$ & $7.29 \mathrm{E}+02$ & $E+00$ & \\
\hline $3.00 \mathrm{E}+02$ & $05 \mathrm{E}+05$ & $3.22 \mathrm{E}+02$ & $E+03$ & $9.79 \mathrm{E}+00$ & $1.01 \mathrm{E}+01$ & $6.41 \mathrm{E}+01$ & $1.59 \mathrm{E}+01$ & $3.02 \mathrm{E}+02$ & $7.29 \mathrm{E}+02$ & $\mathrm{E}+00$ & \\
\hline $3.10 \mathrm{E}+02$ & $E+04$ & $2 \mathrm{E}+02$ & & & & & $1.58 \mathrm{E}+01$ & $E+02$ & $\mathrm{E}+02$ & $E+00$ & \\
\hline $3.20 \mathrm{E}+02$ & $3 \mathrm{E}+04$ & $3.22 \mathrm{E}+02$ & $6 \mathrm{E}+03$ & $8.68 \mathrm{E}+00$ & $E+01$ & $55 \mathrm{E}+01$ & $5 / \mathrm{E}+01$ & $02 E+02$ & $.27 \mathrm{E}+02$ & $E+00$ & $2.69 \mathrm{E}+01$ \\
\hline$E+02$ & +04 & $2 \mathrm{E}+02$ & +03 & +00 & +01 & $2 \mathrm{E}+01$ & +01 & $E+02$ & $25 \mathrm{E}+02$ & $E+00$ & $E+01$ \\
\hline+02 & +04 & $2 \mathrm{E}+02$ & +03 & $E+00$ & $E+01$ & $E+01$ & +01 & $3.02 \mathrm{E}+02$ & $7.23 \mathrm{E}+02$ & $E+00$ & +01 \\
\hline+02 & +04 & $3.22 \mathrm{E}+02$ & +03 & $7.15 \mathrm{E}+00$ & $1.02 \mathrm{E}+01$ & $E+01$ & +01 & $3.02 \mathrm{E}+02$ & $7.20 \mathrm{E}+02$ & $E+00$ & $2.68 \mathrm{E}+01$ \\
\hline $3.60 \mathrm{E}+02$ & $0 \mathrm{E}+04$ & $3.22 \mathrm{E}+02$ & $1.01 \mathrm{E}+03$ & $6.65 \mathrm{E}+00$ & $1.03 \mathrm{E}+01$ & $6.81 \mathrm{E}+01$ & $1.50 \mathrm{E}+01$ & $3.02 \mathrm{E}+02$ & $7.17 \mathrm{E}+02$ & $00 \mathrm{E}+00$ & $2.68 \mathrm{E}+01$ \\
\hline $3.70 \mathrm{E}+02$ & $0 \mathrm{E}+04$ & $3.22 \mathrm{E}+02$ & $\mathrm{E}+02$ & $6.68 \mathrm{E}+00$ & $1.03 \mathrm{E}+01$ & $6.83 \mathrm{E}+01$ & $1.47 \mathrm{E}+01$ & $3.02 \mathrm{E}+02$ & $7.13 \mathrm{E}+02$ & $00 \mathrm{E}+00$ & $2.68 \mathrm{E}+01$ \\
\hline $3.80 \mathrm{E}+02$ & $0 \mathrm{E}+04$ & $22 \mathrm{E}+02$ & $9.90 \mathrm{E}+02$ & $6.70 \mathrm{E}+00$ & $1.04 \mathrm{E}+01$ & $6.85 \mathrm{E}+01$ & $1.44 \mathrm{E}+01$ & $3.02 E+02$ & $7.10 \mathrm{E}+02$ & $00 \mathrm{E}+00$ & $2.69 \mathrm{E}+01$ \\
\hline $3.90 \mathrm{E}+02$ & $00 \mathrm{E}+04$ & $3.22 \mathrm{E}+02$ & $9.82 \mathrm{E}+02$ & $6.71 \mathrm{E}+00$ & $1.04 \mathrm{E}+01$ & $6.87 \mathrm{E}+01$ & $1.42 \mathrm{E}+01$ & $3.02 \mathrm{E}+02$ & $7.07 \mathrm{E}+02$ & $00 \mathrm{E}+00$ & $2.69 \mathrm{E}+01$ \\
\hline $4.00 \mathrm{E}+02$ & $0 \mathrm{E}+04$ & $2 \mathrm{E}+02$ & $9.75 \mathrm{E}+02$ & $6.73 \mathrm{E}+00$ & $24 \mathrm{E}+01$ & $6.90 \mathrm{E}+01$ & & $2 \mathrm{E}+02$ & $5 \mathrm{E}+02$ & $\mathrm{E}+00$ & $2.69 \mathrm{E}+01$ \\
\hline $4.10 \mathrm{E}+02$ & $0 \mathrm{E}+04$ & $3.22 \mathrm{E}+02$ & $E+02$ & $6.74 \mathrm{E}+00$ & $4 \mathrm{E}+01$ & $92 \mathrm{E}+01$ & $\mathrm{E}+01$ & $E+02$ & $2 E+02$ & $E+00$ & $\mathrm{E}+01$ \\
\hline $4.20 \mathrm{E}+02$ & $00 \mathrm{E}+04$ & $3.22 \mathrm{E}+02$ & $\mathrm{E}+02$ & $6.75 \mathrm{E}+00$ & $E+01$ & $94 \mathrm{E}+01$ & 34E+01 & $\bar{E}+02$ & $7.00 \mathrm{E}+02$ & $\mathrm{E}+00$ & $E+01$ \\
\hline$E+02$ & $E+04$ & $22 \mathrm{E}+02$ & +02 & $6.55 \mathrm{E}+00$ & $E+01$ & $E+01$ & $E+01$ & $E+02$ & $6.97 \mathrm{E}+02$ & $E+00$ & $E+01$ \\
\hline $\mathrm{E}+02$ & $E+04$ & $2 \mathrm{E}+02$ & $\mathrm{E}+02$ & $6.35 \mathrm{E}+00$ & $1.05 \mathrm{E}+01$ & $7.01 \mathrm{E}+01$ & $1.31 \mathrm{E}+01$ & $2 \mathrm{E}+02$ & $6.95 \mathrm{E}+02$ & $E+00$ & +01 \\
\hline $4.50 \mathrm{E}+02$ & $E+04$ & $3.22 \mathrm{E}+02$ & $E+02$ & $6.15 \mathrm{E}+00$ & $1.06 \mathrm{E}+01$ & $7.04 \mathrm{E}+01$ & $1.29 \mathrm{E}+01$ & $3.02 \mathrm{E}+02$ & $6.92 \mathrm{E}+02$ & $E+00$ & $E+01$ \\
\hline $4.60 \mathrm{E}+02$ & $6.07 \mathrm{E}+04$ & $3.22 \mathrm{E}+02$ & $5 \mathrm{E}+02$ & $5.96 \mathrm{E}+00$ & $1.06 \mathrm{E}+01$ & $7.08 \mathrm{E}+01$ & $1.27 \mathrm{E}+01$ & $02 \mathrm{E}+02$ & $6.89 \mathrm{E}+02$ & $00 \mathrm{E}+00$ & $2.71 \mathrm{E}+01$ \\
\hline $4.70 \mathrm{E}+02$ & $5.83 \mathrm{E}+04$ & $3.22 \mathrm{E}+02$ & $9.16 \mathrm{E}+02$ & $5.76 \mathrm{E}+00$ & $1.07 \mathrm{E}+01$ & $7.11 \mathrm{E}+01$ & $1.25 \mathrm{E}+01$ & $3.02 \mathrm{E}+02$ & $6.87 \mathrm{E}+02$ & $.00 \mathrm{E}+00$ & $2.72 \mathrm{E}+01$ \\
\hline $4.80 \mathrm{E}+02$ & $60 \mathrm{E}+04$ & $3.22 \mathrm{E}+02$ & $9.07 \mathrm{E}+02$ & $5.57 \mathrm{E}+00$ & $1.07 \mathrm{E}+01$ & $7.14 \mathrm{E}+01$ & $1.23 \mathrm{E}+01$ & $3.02 \mathrm{E}+02$ & $6.84 \mathrm{E}+02$ & $.00 \mathrm{E}+00$ & $2.72 \mathrm{E}+01$ \\
\hline $4.90 \mathrm{E}+02$ & $84 \mathrm{E}+04$ & $3.22 \mathrm{E}+02$ & $\mathrm{E}+02$ & $5.54 \mathrm{E}+00$ & $1.08 \mathrm{E}+01$ & $7.16 \mathrm{E}+01$ & $1.21 \mathrm{E}+01$ & $3.02 \mathrm{E}+02$ & $6.81 \mathrm{E}+02$ & $00 \mathrm{E}+00$ & $2.73 E+01$ \\
\hline $5.00 \mathrm{E}+02$ & $48 \mathrm{E}+04$ & $3.22 \mathrm{E}+02$ & $8.93 \mathrm{E}+02$ & $5.50 \mathrm{E}+00$ & $1.08 \mathrm{E}+01$ & $7.18 \mathrm{E}+01$ & $1.19 \mathrm{E}+01$ & $3.02 \mathrm{E}+02$ & $6.78 \mathrm{E}+02$ & $.00 \mathrm{E}+00$ & $2.74 \mathrm{E}+01$ \\
\hline $5.10 \mathrm{E}+02$ & $2 \mathrm{E}+04$ & $E+02$ & 2 & 0 & & 1 & & 02 & 02 & $E+00$ & 01 \\
\hline $5.20 \mathrm{E}+02$ & +04 & $2 \mathrm{E}+02$ & $\mathrm{E}+02$ & $5.44 \mathrm{E}+00$ & $=+41$ & 1. $2 \angle E+\mathrm{U} 1$ & & $E+02$ & $6.73 \mathrm{E}+02$ & $E+00$ & $2.75 \mathrm{E}+01$ \\
\hline $30 \mathrm{E}+02$ & $1 \mathrm{E}+04$ & $22 \mathrm{E}+02$ & $3 \mathrm{E}+02$ & $5.40 \mathrm{E}+00$ & $1.10 \mathrm{E}+01$ & $7.24 \mathrm{E}+01$ & $1.13 \mathrm{E}+01$ & $3.02 \mathrm{E}+02$ & $6.70 \mathrm{E}+02$ & $.00 \mathrm{E}+00$ & $2.75 \mathrm{E}+01$ \\
\hline $\mathrm{E}+02$ & +04 & $2 \mathrm{E}+02$ & $\mathrm{E}+02$ & $E+00$ & $E+01$ & $7.25 \mathrm{E}+01$ & $11 \mathrm{E}+01$ & $2 \mathrm{E}+02$ & $68 \mathrm{E}+02$ & $E+00$ & $6 \mathrm{E}+01$ \\
\hline $5.50 \mathrm{E}+02$ & $5.54 \mathrm{E}+04$ & $3.22 \mathrm{E}+02$ & $8.64 \mathrm{E}+02$ & $5.66 \mathrm{E}+00$ & $1.10 \mathrm{E}+01$ & $7.25 \mathrm{E}+01$ & $1.08 \mathrm{E}+01$ & $3.02 \mathrm{E}+02$ & $6.66 \mathrm{E}+02$ & $.00 \mathrm{E}+00$ & $2.76 \mathrm{E}+01$ \\
\hline $5.60 \mathrm{E}+02$ & $5.83 \mathrm{E}+04$ & $3.22 \mathrm{E}+02$ & $8.62 \mathrm{E}+02$ & $5.95 \mathrm{E}+00$ & $1.10 \mathrm{E}+01$ & $7.24 \mathrm{E}+01$ & $1.06 \mathrm{E}+01$ & $3.02 \mathrm{E}+02$ & $6.64 \mathrm{E}+02$ & $0.00 \mathrm{E}+00$ & $2.77 \mathrm{E}+01$ \\
\hline $5.70 \mathrm{E}+02$ & $6.12 \mathrm{E}+04$ & $3.22 \mathrm{E}+02$ & $8.61 \mathrm{E}+02$ & $6.22 \mathrm{E}+00$ & $1.10 \mathrm{E}+01$ & $7.23 \mathrm{E}+01$ & $1.05 \mathrm{E}+01$ & $3.02 \mathrm{E}+02$ & $6.63 \mathrm{E}+02$ & $.00 \mathrm{E}+00$ & $2.77 \mathrm{E}+01$ \\
\hline $5.80 \mathrm{E}+02$ & $6.42 \mathrm{E}+04$ & $3.22 \mathrm{E}+02$ & $1 \mathrm{E}+02$ & $6.49 \mathrm{E}+00$ & $1.09 \mathrm{E}+01$ & $7.23 \mathrm{E}+01$ & $1.03 \mathrm{E}+01$ & $3.02 \mathrm{E}+02$ & $6.62 \mathrm{E}+02$ & $0.00 \mathrm{E}+00$ & $2.77 \mathrm{E}+01$ \\
\hline $5.90 \mathrm{E}+02$ & $6.71 \mathrm{E}+04$ & $3.22 \mathrm{E}+02$ & $8.61 \mathrm{E}+02$ & $6.74 \mathrm{E}+00$ & $1.09 \mathrm{E}+01$ & $7.22 \mathrm{E}+01$ & $1.02 \mathrm{E}+01$ & $3.02 \mathrm{E}+02$ & $6.61 \mathrm{E}+02$ & $0.00 \mathrm{E}+00$ & $2.76 \mathrm{E}+01$ \\
\hline
\end{tabular}


WSRC-TR-2001-00405

\begin{tabular}{|c|c|c|c|c|c|c|c|c|c|c|c|}
\hline TIME & $\begin{array}{c}\text { Target Gas } \\
\text { Rad. (2) }\end{array}$ & $\begin{array}{c}\text { Target } \\
\text { Convec. (2) } \\
\end{array}$ & Upper N2 (1) & Upper O2 (1) & $\begin{array}{c}\text { Upper CO2 } \\
\text { (1) }\end{array}$ & Upper CO (1) & $\begin{array}{c}\text { Upper HCN } \\
(1) \\
\end{array}$ & $\begin{array}{c}\text { Upper HCL } \\
\text { (1) } \\
\end{array}$ & \begin{tabular}{|c|} 
Upper TUHC \\
(1) \\
\end{tabular} & $\begin{array}{c}\text { Upper } \mathrm{H} 2 \mathrm{O} \\
\text { (1) }\end{array}$ & Upper OD (1) \\
\hline $0.00 \mathrm{E}+00$ & $3.92 \mathrm{E}+00$ & $0.00 \mathrm{E}+00$ & $7.77 \mathrm{E}+01$ & $2.05 \mathrm{E}+01$ & $0.00 \mathrm{E}+00$ & $0.00 \mathrm{E}+00$ & $0.00 \mathrm{E}+00$ & $0.00 \mathrm{E}+00$ & $0.00 \mathrm{E}+00$ & $1.75 \mathrm{E}+00$ & $0.00 \mathrm{E}+00$ \\
\hline $1.00 \mathrm{E}+01$ & $.01 \mathrm{E}+00$ & $-1.55 \mathrm{E}-02$ & $7.77 \mathrm{E}+01$ & $2.05 \mathrm{E}+01$ & 1.87E-02 & $0.00 \mathrm{E}+00$ & $0.00 \mathrm{E}+00$ & $.00 \mathrm{E}+00$ & $0.00 \mathrm{E}+00$ & $1.78 \mathrm{E}+00$ & $0.00 \mathrm{E}+00$ \\
\hline $2.00 \mathrm{E}+01$ & $1.12 \mathrm{E}+01$ & $-3.10 \mathrm{E}-02$ & $7.77 \mathrm{E}+01$ & $2.05 \mathrm{E}+01$ & $3.34 \mathrm{E}-02$ & $0.00 \mathrm{E}+00$ & $0.00 \mathrm{E}+00$ & $0.00 \mathrm{E}+00$ & $0.00 \mathrm{E}+00$ & $1.81 \mathrm{E}+00$ & $0.00 \mathrm{E}+00$ \\
\hline $3.00 \mathrm{E}+01$ & $1.57 \mathrm{E}+01$ & $-4.01 \mathrm{E}-02$ & $7.77 \mathrm{E}+01$ & $2.04 \mathrm{E}+01$ & 4.87E-02 & $0.00 \mathrm{E}+00$ & $0.00 \mathrm{E}+00$ & $0.00 \mathrm{E}+00$ & $0.00 \mathrm{E}+00$ & $1.84 \mathrm{E}+00$ & $0.00 \mathrm{E}+00$ \\
\hline $4.00 \mathrm{E}+01$ & $2.02 \mathrm{E}+01$ & $-4.11 \mathrm{E}-02$ & $7.77 \mathrm{E}+01$ & $2.04 \mathrm{E}+01$ & $6.52 \mathrm{E}-02$ & $0.00 \mathrm{E}+00$ & $0.00 \mathrm{E}+00$ & $0.00 \mathrm{E}+00$ & $0.00 \mathrm{E}+00$ & $1.87 \mathrm{E}+00$ & $0.00 \mathrm{E}+00$ \\
\hline $5.00 \mathrm{E}+01$ & $2.46 \mathrm{E}+01$ & $-3.37 \mathrm{E}-02$ & $7.76 \mathrm{E}+01$ & $2.04 \mathrm{E}+01$ & $8.30 \mathrm{E}-02$ & $0.00 \mathrm{E}+00$ & $0.00 \mathrm{E}+00$ & $0.00 \mathrm{E}+00$ & $0.00 \mathrm{E}+00$ & $1.90 \mathrm{E}+00$ & $0.00 \mathrm{E}+00$ \\
\hline $6.00 \mathrm{E}+01$ & $2.89 \mathrm{E}+01$ & $-1.84 \mathrm{E}-02$ & $7.76 \mathrm{E}+01$ & $2.03 \mathrm{E}+01$ & $1.02 \mathrm{E}-01$ & $0.00 \mathrm{E}+00$ & $0.00 \mathrm{E}+00$ & $0.00 \mathrm{E}+00$ & $0.00 \mathrm{E}+00$ & $1.94 \mathrm{E}+00$ & $0.00 \mathrm{E}+00$ \\
\hline $7.00 \mathrm{E}+01$ & $3.31 \mathrm{E}+01$ & $2.10 \mathrm{E}-03$ & $7.76 \mathrm{E}+01$ & $2.03 \mathrm{E}+01$ & $1.23 \mathrm{E}-01$ & $0.00 \mathrm{E}+00$ & $0.00 \mathrm{E}+00$ & $0.00 \mathrm{E}+00$ & $0.00 \mathrm{E}+00$ & $1.98 \mathrm{E}+00$ & $0.00 \mathrm{E}+00$ \\
\hline $8.00 \mathrm{E}+01$ & $3.70 \mathrm{E}+01$ & $2.14 \mathrm{E}-02$ & $7.76 \mathrm{E}+01$ & $2.03 \mathrm{E}+01$ & 1.44E-01 & $0.00 \mathrm{E}+00$ & $0.00 \mathrm{E}+00$ & $0.00 \mathrm{E}+00$ & $0.00 \mathrm{E}+00$ & $2.02 \mathrm{E}+00$ & $0.00 \mathrm{E}+00$ \\
\hline $9.00 \mathrm{E}+01$ & $4.07 \mathrm{E}+01$ & $4.02 \mathrm{E}-02$ & $7.75 \mathrm{E}+01$ & $2.02 \mathrm{E}+01$ & 1.67E-01 & $0.00 \mathrm{E}+00$ & $0.00 \mathrm{E}+00$ & $0.00 \mathrm{E}+00$ & $0.00 \mathrm{E}+00$ & $2.06 \mathrm{E}+00$ & $0.00 \mathrm{E}+00$ \\
\hline $1.00 \mathrm{E}+02$ & $4.42 \mathrm{E}+01$ & $5.86 \mathrm{E}-02$ & $7.75 \mathrm{E}+01$ & $2.02 \mathrm{E}+01$ & 1.91E-01 & $0.00 \mathrm{E}+00$ & $0.00 \mathrm{E}+00$ & $0.00 \mathrm{E}+00$ & $0.00 \mathrm{E}+00$ & $2.11 \mathrm{E}+00$ & $0.00 \mathrm{E}+00$ \\
\hline $1.10 \mathrm{E}+02$ & $4.75 \mathrm{E}+01$ & $7.61 \mathrm{E}-02$ & $7.75 \mathrm{E}+01$ & $2.01 \mathrm{E}+01$ & 2.16E-01 & $0.00 \mathrm{E}+00$ & $0.00 \mathrm{E}+00$ & $0.00 \mathrm{E}+00$ & $0.00 \mathrm{E}+00$ & $2.15 \mathrm{E}+00$ & $0.00 \mathrm{E}+00$ \\
\hline $1.20 \mathrm{E}+02$ & $5.06 \mathrm{E}+01$ & $9.23 \mathrm{E}-02$ & $7.75 \mathrm{E}+01$ & $2.01 \mathrm{E}+01$ & 2.43E-01 & $0.00 \mathrm{E}+00$ & $0.00 \mathrm{E}+00$ & $0.00 \mathrm{E}+00$ & $0.00 \mathrm{E}+00$ & $2.21 \mathrm{E}+00$ & $0.00 \mathrm{E}+00$ \\
\hline $1.30 \mathrm{E}+02$ & $5.35 \mathrm{E}+01$ & $1.02 \mathrm{E}-01$ & $7.74 \mathrm{E}+01$ & $2.00 \mathrm{E}+01$ & 2.70E-01 & $0.00 \mathrm{E}+00$ & $0.00 \mathrm{E}+00$ & $0.00 \mathrm{E}+00$ & $0.00 \mathrm{E}+00$ & $2.26 \mathrm{E}+00$ & $0.00 \mathrm{E}+00$ \\
\hline $1.40 \mathrm{E}+02$ & $5.62 \mathrm{E}+01$ & $8.89 \mathrm{E}-02$ & $7.74 \mathrm{E}+01$ & $2.00 \mathrm{E}+01$ & $2.96 \mathrm{E}-01$ & $0.00 \mathrm{E}+00$ & $0.00 \mathrm{E}+00$ & $0.00 \mathrm{E}+00$ & $0.00 \mathrm{E}+00$ & $2.31 \mathrm{E}+00$ & $0.00 \mathrm{E}+00$ \\
\hline $1.50 \mathrm{E}+02$ & $5.86 \mathrm{E}+01$ & $6.09 \mathrm{E}-02$ & $7.74 \mathrm{E}+01$ & $1.99 \mathrm{E}+01$ & $3.21 \mathrm{E}-01$ & $0.00 \mathrm{E}+00$ & $0.00 \mathrm{E}+00$ & $0.00 \mathrm{E}+00$ & $0.00 \mathrm{E}+00$ & $2.35 \mathrm{E}+00$ & $0.00 \mathrm{E}+00$ \\
\hline $1.60 \mathrm{E}+02$ & $6.08 \mathrm{E}+01$ & $2.34 \mathrm{E}-02$ & $7.74 \mathrm{E}+01$ & $1.99 \mathrm{E}+01$ & $3.45 \mathrm{E}-01$ & $0.00 \mathrm{E}+00$ & $0.00 \mathrm{E}+00$ & $0.00 \mathrm{E}+00$ & $0.00 \mathrm{E}+00$ & $2.40 \mathrm{E}+00$ & $0.00 \mathrm{E}+00$ \\
\hline $1.70 \mathrm{E}+02$ & $6.28 \mathrm{E}+01$ & $-1.95 \mathrm{E}-02$ & $7.73 \mathrm{E}+01$ & $1.98 \mathrm{E}+01$ & 3.68E-01 & $0.00 \mathrm{E}+00$ & $0.00 \mathrm{E}+00$ & $0.00 \mathrm{E}+00$ & $0.00 \mathrm{E}+00$ & $2.44 \mathrm{E}+00$ & $0.00 \mathrm{E}+00$ \\
\hline $1.80 \mathrm{E}+02$ & $6.46 \mathrm{E}+01$ & $-6.46 \mathrm{E}-02$ & $7.73 \mathrm{E}+01$ & $1.98 \mathrm{E}+01$ & $3.90 \mathrm{E}-01$ & $0.00 \mathrm{E}+00$ & $0.00 \mathrm{E}+00$ & $0.00 \mathrm{E}+00$ & $0.00 \mathrm{E}+00$ & $2.48 \mathrm{E}+00$ & $0.00 \mathrm{E}+00$ \\
\hline $1.90 \mathrm{E}+02$ & $6.63 \mathrm{E}+01$ & $-1.14 \mathrm{E}-01$ & $7.73 \mathrm{E}+01$ & $1.98 \mathrm{E}+01$ & $4.12 \mathrm{E}-01$ & $0.00 \mathrm{E}+00$ & $0.00 \mathrm{E}+00$ & $0.00 \mathrm{E}+00$ & $0.00 \mathrm{E}+00$ & $2.52 \mathrm{E}+00$ & $0.00 \mathrm{E}+00$ \\
\hline $2.00 \mathrm{E}+02$ & $6.77 \mathrm{E}+01$ & $-1.77 \mathrm{E}-01$ & $7.73 \mathrm{E}+01$ & $1.97 \mathrm{E}+01$ & $4.31 \mathrm{E}-01$ & $0.00 \mathrm{E}+00$ & $0.00 \mathrm{E}+00$ & $0.00 \mathrm{E}+00$ & $0.00 \mathrm{E}+00$ & $2.56 \mathrm{E}+00$ & $0.00 \mathrm{E}+00$ \\
\hline $2.10 \mathrm{E}+02$ & $6.89 \mathrm{E}+01$ & $-2.46 \mathrm{E}-01$ & $7.73 \mathrm{E}+01$ & $1.97 \mathrm{E}+01$ & 4.48E-01 & $0.00 \mathrm{E}+00$ & $0.00 \mathrm{E}+00$ & $0.00 \mathrm{E}+00$ & $0.00 \mathrm{E}+00$ & $2.59 \mathrm{E}+00$ & $E+00$ \\
\hline $2.20 \mathrm{E}+02$ & $6.99 \mathrm{E}+01$ & $-3.16 \mathrm{E}-01$ & $7.72 \mathrm{E}+01$ & $1.97 \mathrm{E}+01$ & 4.64E-01 & $0.00 \mathrm{E}+00$ & $0.00 \mathrm{E}+00$ & $0.00 \mathrm{E}+00$ & $0.00 \mathrm{E}+00$ & $2.62 \mathrm{E}+00$ & $0.00 \mathrm{E}+00$ \\
\hline $2.30 \mathrm{E}+02$ & $7.07 \mathrm{E}+01$ & $-3.79 \mathrm{E}-01$ & $7.72 \mathrm{E}+01$ & $1.96 \mathrm{E}+01$ & $4.78 \mathrm{E}-01$ & $0.00 \mathrm{E}+00$ & $0.00 \mathrm{E}+00$ & $0.00 \mathrm{E}+00$ & $0.00 \mathrm{E}+00$ & $2.65 \mathrm{E}+00$ & $0.00 \mathrm{E}+00$ \\
\hline $2.40 \mathrm{E}+02$ & $7.13 \mathrm{E}+01$ & $-4.30 \mathrm{E}-01$ & $7.72 \mathrm{E}+01$ & $1.96 \mathrm{E}+01$ & 4.91E-01 & $0.00 \mathrm{E}+00$ & $0.00 \mathrm{E}+00$ & $0.00 \mathrm{E}+00$ & $0.00 \mathrm{E}+00$ & $2.68 \mathrm{E}+00$ & $0.00 \mathrm{E}+00$ \\
\hline $2.50 \mathrm{E}+02$ & $7.18 \mathrm{E}+01$ & $-4.62 \mathrm{E}-01$ & $7.72 \mathrm{E}+01$ & $1.96 \mathrm{E}+01$ & 5.02E-01 & $0.00 \mathrm{E}+00$ & $0.00 \mathrm{E}+00$ & $0.00 \mathrm{E}+00$ & $0.00 \mathrm{E}+00$ & $2.70 \mathrm{E}+00$ & $\mathrm{E}+00$ \\
\hline $2.60 \mathrm{E}+02$ & $7.22 \mathrm{E}+01$ & $-4.67 \mathrm{E}-01$ & $7.72 \mathrm{E}+01$ & $1.96 \mathrm{E}+01$ & $5.13 E-01$ & $0.00 \mathrm{E}+00$ & $0.00 \mathrm{E}+00$ & $0.00 \mathrm{E}+00$ & $0.00 \mathrm{E}+00$ & $2.72 \mathrm{E}+00$ & $0.00 \mathrm{E}+00$ \\
\hline $2.70 \mathrm{E}+02$ & $7.26 \mathrm{E}+01$ & $-4.55 \mathrm{E}-01$ & $7.72 \mathrm{E}+01$ & $1.96 \mathrm{E}+01$ & 5.24E-01 & $0.00 \mathrm{E}+00$ & $0.00 \mathrm{E}+00$ & $0.00 \mathrm{E}+00$ & $0.00 \mathrm{E}+00$ & $2.74 \mathrm{E}+00$ & $0.00 \mathrm{E}+00$ \\
\hline $2.80 \mathrm{E}+02$ & $7.28 \mathrm{E}+01$ & $-4.34 \mathrm{E}-01$ & $7.72 \mathrm{E}+01$ & $1.95 \mathrm{E}+01$ & 5.34E-01 & $0.00 \mathrm{E}+00$ & $0.00 \mathrm{E}+00$ & $0.00 \mathrm{E}+00$ & $0.00 \mathrm{E}+00$ & $2.76 \mathrm{E}+00$ & $0.00 \mathrm{E}+00$ \\
\hline $2.90 \mathrm{E}+02$ & $7.31 \mathrm{E}+01$ & $-4.10 \mathrm{E}-01$ & $7.72 \mathrm{E}+01$ & $1.95 \mathrm{E}+01$ & $5.43 \mathrm{E}-01$ & $0.00 \mathrm{E}+00$ & $0.00 \mathrm{E}+00$ & $0.00 \mathrm{E}+00$ & $0.00 \mathrm{E}+00$ & $2.77 \mathrm{E}+00$ & $0.00 \mathrm{E}+00$ \\
\hline $3.00 \mathrm{E}+02$ & $7.32 \mathrm{E}+01$ & $-3.86 \mathrm{E}-01$ & $7.72 \mathrm{E}+01$ & $1.95 \mathrm{E}+01$ & 5.52E-01 & $0.00 \mathrm{E}+00$ & $0.00 \mathrm{E}+00$ & $0.00 \mathrm{E}+00$ & $0.00 \mathrm{E}+00$ & $2.79 \mathrm{E}+00$ & $0.00 \mathrm{E}+00$ \\
\hline $3.10 \mathrm{E}+02$ & $7.34 \mathrm{E}+01$ & $-3.60 \mathrm{E}-01$ & $7.71 \mathrm{E}+01$ & $1.95 \mathrm{E}+01$ & $5.60 \mathrm{E}-01$ & $0.00 \mathrm{E}+00$ & $0.00 \mathrm{E}+00$ & $0.00 \mathrm{E}+00$ & $0.00 \mathrm{E}+00$ & $2.81 \mathrm{E}+00$ & $0.00 \mathrm{E}+00$ \\
\hline $3.20 \mathrm{E}+02$ & $7.35 \mathrm{E}+01$ & $-3.36 \mathrm{E}-01$ & $7.71 \mathrm{E}+01$ & $1.95 \mathrm{E}+01$ & 5.67E-01 & $0.00 \mathrm{E}+00$ & $0.00 \mathrm{E}+00$ & $0.00 \mathrm{E}+00$ & $0.00 \mathrm{E}+00$ & $2.82 \mathrm{E}+00$ & $0.00 \mathrm{E}+00$ \\
\hline $3.30 \mathrm{E}+02$ & $7.35 \mathrm{E}+01$ & $-3.14 \mathrm{E}-01$ & $7.71 \mathrm{E}+01$ & $1.95 \mathrm{E}+01$ & $5.75 \mathrm{E}-01$ & $0.00 \mathrm{E}+00$ & $0.00 \mathrm{E}+00$ & $0.00 \mathrm{E}+00$ & $0.00 \mathrm{E}+00$ & $2.83 \mathrm{E}+00$ & $0.00 \mathrm{E}+00$ \\
\hline $3.40 \mathrm{E}+02$ & $7.35 \mathrm{E}+01$ & $-2.94 \mathrm{E}-01$ & $7.71 \mathrm{E}+01$ & $1.94 \mathrm{E}+01$ & $5.81 \mathrm{E}-01$ & $0.00 \mathrm{E}+00$ & $0.00 \mathrm{E}+00$ & $0.00 \mathrm{E}+00$ & $0.00 \mathrm{E}+00$ & $2.85 \mathrm{E}+00$ & $0.00 \mathrm{E}+00$ \\
\hline $3.50 \mathrm{E}+02$ & $7.35 \mathrm{E}+01$ & $-2.77 \mathrm{E}-01$ & $7.71 \mathrm{E}+01$ & $1.94 \mathrm{E}+01$ & 5.87E-01 & $0.00 \mathrm{E}+00$ & $0.00 \mathrm{E}+00$ & $0.00 \mathrm{E}+00$ & $0.00 \mathrm{E}+00$ & $2.86 \mathrm{E}+00$ & $0.00 \mathrm{E}+00$ \\
\hline $3.60 \mathrm{E}+02$ & $7.35 \mathrm{E}+01$ & $-2.61 \mathrm{E}-01$ & $7.71 \mathrm{E}+01$ & $1.94 \mathrm{E}+01$ & 5.93E-01 & $0.00 \mathrm{E}+00$ & $0.00 \mathrm{E}+00$ & $0.00 \mathrm{E}+00$ & $0.00 \mathrm{E}+00$ & $2.87 \mathrm{E}+00$ & $0.00 \mathrm{E}+00$ \\
\hline $3.70 \mathrm{E}+02$ & $7.34 \mathrm{E}+01$ & $-2.48 \mathrm{E}-01$ & $7.71 \mathrm{E}+01$ & $1.94 \mathrm{E}+01$ & $5.98 \mathrm{E}-01$ & $0.00 \mathrm{E}+00$ & $0.00 \mathrm{E}+00$ & $0.00 \mathrm{E}+00$ & $0.00 \mathrm{E}+00$ & $2.88 \mathrm{E}+00$ & $0.00 \mathrm{E}+00$ \\
\hline $3.80 \mathrm{E}+02$ & $7.34 \mathrm{E}+01$ & $-2.35 \mathrm{E}-01$ & $7.71 \mathrm{E}+01$ & $1.94 \mathrm{E}+01$ & $6.03 \mathrm{E}-01$ & $0.00 \mathrm{E}+00$ & $0.00 \mathrm{E}+00$ & $0.00 \mathrm{E}+00$ & $0.00 \mathrm{E}+00$ & $2.89 \mathrm{E}+00$ & $0.00 \mathrm{E}+00$ \\
\hline $3.90 \mathrm{E}+02$ & $7.33 \mathrm{E}+01$ & $-2.24 \mathrm{E}-01$ & $7.71 \mathrm{E}+01$ & $1.94 \mathrm{E}+01$ & $6.08 \mathrm{E}-01$ & $0.00 \mathrm{E}+00$ & $0.00 \mathrm{E}+00$ & $0.00 \mathrm{E}+00$ & $0.00 \mathrm{E}+00$ & $2.90 \mathrm{E}+00$ & $0.00 \mathrm{E}+00$ \\
\hline $4.00 \mathrm{E}+02$ & $7.33 \mathrm{E}+01$ & $-2.15 \mathrm{E}-01$ & $7.71 \mathrm{E}+01$ & $1.94 \mathrm{E}+01$ & $6.14 \mathrm{E}-01$ & $0.00 \mathrm{E}+00$ & $0.00 \mathrm{E}+00$ & $0.00 \mathrm{E}+00$ & $0.00 \mathrm{E}+00$ & $2.91 \mathrm{E}+00$ & $0.00 \mathrm{E}+00$ \\
\hline $4.10 \mathrm{E}+02$ & $7.32 \mathrm{E}+01$ & $-2.06 \mathrm{E}-01$ & $7.71 \mathrm{E}+01$ & $1.94 \mathrm{E}+01$ & $6.19 \mathrm{E}-01$ & $0.00 \mathrm{E}+00$ & $0.00 \mathrm{E}+00$ & $0.00 \mathrm{E}+00$ & $0.00 \mathrm{E}+00$ & $2.92 \mathrm{E}+00$ & $0.00 \mathrm{E}+00$ \\
\hline $4.20 \mathrm{E}+02$ & $7.32 \mathrm{E}+01$ & $-1.98 \mathrm{E}-01$ & $7.71 \mathrm{E}+01$ & $1.94 \mathrm{E}+01$ & $6.24 \mathrm{E}-01$ & $0.00 \mathrm{E}+00$ & $0.00 \mathrm{E}+00$ & $0.00 \mathrm{E}+00$ & $0.00 \mathrm{E}+00$ & $2.93 \mathrm{E}+00$ & $0.00 \mathrm{E}+00$ \\
\hline $4.30 \mathrm{E}+02$ & $7.32 \mathrm{E}+01$ & $-1.90 \mathrm{E}-01$ & $7.71 \mathrm{E}+01$ & $1.94 \mathrm{E}+01$ & $6.29 \mathrm{E}-01$ & $0.00 \mathrm{E}+00$ & $0.00 \mathrm{E}+00$ & $0.00 \mathrm{E}+00$ & $0.00 \mathrm{E}+00$ & $2.93 \mathrm{E}+00$ & $0.00 \mathrm{E}+00$ \\
\hline $4.40 \mathrm{E}+02$ & $7.32 \mathrm{E}+01$ & $-1.83 \mathrm{E}-01$ & $7.71 \mathrm{E}+01$ & $1.93 \mathrm{E}+01$ & 6.34E-01 & $0.00 \mathrm{E}+00$ & $0.00 \mathrm{E}+00$ & $0.00 \mathrm{E}+00$ & $0.00 \mathrm{E}+00$ & $2.94 \mathrm{E}+00$ & $0.00 \mathrm{E}+00$ \\
\hline $4.50 \mathrm{E}+02$ & $7.31 \mathrm{E}+01$ & $-1.76 \mathrm{E}-01$ & $7.71 \mathrm{E}+01$ & $1.93 \mathrm{E}+01$ & $6.39 \mathrm{E}-01$ & $0.00 \mathrm{E}+00$ & $0.00 \mathrm{E}+00$ & $0.00 \mathrm{E}+00$ & $0.00 \mathrm{E}+00$ & $2.95 \mathrm{E}+00$ & $0.00 \mathrm{E}+00$ \\
\hline $4.60 \mathrm{E}+02$ & $7.31 \mathrm{E}+01$ & $-1.69 \mathrm{E}-01$ & $7.71 \mathrm{E}+01$ & $1.93 \mathrm{E}+01$ & $6.44 \mathrm{E}-01$ & $0.00 \mathrm{E}+00$ & $0.00 \mathrm{E}+00$ & $0.00 \mathrm{E}+00$ & $0.00 \mathrm{E}+00$ & $2.96 \mathrm{E}+00$ & $0.00 \mathrm{E}+00$ \\
\hline $4.70 \mathrm{E}+02$ & $7.30 \mathrm{E}+01$ & $-1.63 E-01$ & $7.71 \mathrm{E}+01$ & $1.93 \mathrm{E}+01$ & $6.48 \mathrm{E}-01$ & $0.00 \mathrm{E}+00$ & $0.00 \mathrm{E}+00$ & $0.00 \mathrm{E}+00$ & $0.00 \mathrm{E}+00$ & $2.97 \mathrm{E}+00$ & $0.00 \mathrm{E}+00$ \\
\hline $4.80 \mathrm{E}+02$ & $7.29 \mathrm{E}+01$ & $-1.57 \mathrm{E}-01$ & $7.71 \mathrm{E}+01$ & $1.93 \mathrm{E}+01$ & $6.52 \mathrm{E}-01$ & $0.00 \mathrm{E}+00$ & $0.00 \mathrm{E}+00$ & $0.00 \mathrm{E}+00$ & $0.00 \mathrm{E}+00$ & $2.98 \mathrm{E}+00$ & $0.00 \mathrm{E}+00$ \\
\hline $4.90 \mathrm{E}+02$ & $7.29 \mathrm{E}+01$ & $-1.51 \mathrm{E}-01$ & $7.71 \mathrm{E}+01$ & $1.93 \mathrm{E}+01$ & $6.56 \mathrm{E}-01$ & $0.00 \mathrm{E}+00$ & $0.00 \mathrm{E}+00$ & $0.00 \mathrm{E}+00$ & $0.00 \mathrm{E}+00$ & $2.98 \mathrm{E}+00$ & $0.00 \mathrm{E}+00$ \\
\hline $5.00 \mathrm{E}+02$ & $7.28 \mathrm{E}+01$ & $-1.46 \mathrm{E}-01$ & $7.71 \mathrm{E}+01$ & $1.93 \mathrm{E}+01$ & $6.60 \mathrm{E}-01$ & $0.00 \mathrm{E}+00$ & $0.00 \mathrm{E}+00$ & $0.00 \mathrm{E}+00$ & $0.00 \mathrm{E}+00$ & $2.99 \mathrm{E}+00$ & $0.00 \mathrm{E}+00$ \\
\hline $5.10 \mathrm{E}+02$ & $7.27 \mathrm{E}+01$ & $-1.42 \mathrm{E}-01$ & $7.70 \mathrm{E}+01$ & $1.93 \mathrm{E}+01$ & $6.64 \mathrm{E}-01$ & $0.00 \mathrm{E}+00$ & $0.00 \mathrm{E}+00$ & $0.00 \mathrm{E}+00$ & $0.00 \mathrm{E}+00$ & $3.00 \mathrm{E}+00$ & $0.00 \mathrm{E}+00$ \\
\hline $5.20 \mathrm{E}+02$ & $7.27 \mathrm{E}+01$ & $-1.37 \mathrm{E}-01$ & $7.70 \mathrm{E}+01$ & $1.93 \mathrm{E}+01$ & $6.68 \mathrm{E}-01$ & $0.00 \mathrm{E}+00$ & $0.00 \mathrm{E}+00$ & $0.00 \mathrm{E}+00$ & $0.00 \mathrm{E}+00$ & $3.00 \mathrm{E}+00$ & $0.00 \mathrm{E}+00$ \\
\hline $5.30 \mathrm{E}+02$ & $7.26 \mathrm{E}+01$ & $-1.34 \mathrm{E}-01$ & $7.70 \mathrm{E}+01$ & $1.93 \mathrm{E}+01$ & $6.72 \mathrm{E}-01$ & $0.00 \mathrm{E}+00$ & $0.00 \mathrm{E}+00$ & $0.00 \mathrm{E}+00$ & $0.00 \mathrm{E}+00$ & $3.01 \mathrm{E}+00$ & $0.00 \mathrm{E}+00$ \\
\hline $5.40 \mathrm{E}+02$ & $7.25 \mathrm{E}+01$ & $-1.30 \mathrm{E}-01$ & $7.70 \mathrm{E}+01$ & $1.93 \mathrm{E}+01$ & $6.75 \mathrm{E}-01$ & $0.00 \mathrm{E}+00$ & $0.00 \mathrm{E}+00$ & $0.00 \mathrm{E}+00$ & $0.00 \mathrm{E}+00$ & $3.02 \mathrm{E}+00$ & $0.00 \mathrm{E}+00$ \\
\hline $5.50 \mathrm{E}+02$ & $7.25 \mathrm{E}+01$ & $-1.27 \mathrm{E}-01$ & $7.70 \mathrm{E}+01$ & $1.93 \mathrm{E}+01$ & $6.79 \mathrm{E}-01$ & $0.00 \mathrm{E}+00$ & $0.00 \mathrm{E}+00$ & $0.00 \mathrm{E}+00$ & $0.00 \mathrm{E}+00$ & $3.02 \mathrm{E}+00$ & $0.00 \mathrm{E}+00$ \\
\hline $5.60 \mathrm{E}+02$ & $7.24 \mathrm{E}+01$ & $-1.24 \mathrm{E}-01$ & $7.70 \mathrm{E}+01$ & $1.93 \mathrm{E}+01$ & $6.83 \mathrm{E}-01$ & $0.00 \mathrm{E}+00$ & $0.00 \mathrm{E}+00$ & $0.00 \mathrm{E}+00$ & $0.00 \mathrm{E}+00$ & $3.03 \mathrm{E}+00$ & $0.00 \mathrm{E}+00$ \\
\hline $5.70 \mathrm{E}+02$ & $7.24 \mathrm{E}+01$ & $-1.22 \mathrm{E}-01$ & $7.70 \mathrm{E}+01$ & $1.92 \mathrm{E}+01$ & $6.88 \mathrm{E}-01$ & $0.00 \mathrm{E}+00$ & $0.00 \mathrm{E}+00$ & $0.00 \mathrm{E}+00$ & $0.00 \mathrm{E}+00$ & $3.04 \mathrm{E}+00$ & $0.00 \mathrm{E}+00$ \\
\hline $5.80 \mathrm{E}+02$ & $7.25 \mathrm{E}+01$ & $-1.20 \mathrm{E}-01$ & $7.70 \mathrm{E}+01$ & $1.92 \mathrm{E}+01$ & 6.92E-01 & $0.00 \mathrm{E}+00$ & $0.00 \mathrm{E}+00$ & $0.00 \mathrm{E}+00$ & $0.00 \mathrm{E}+00$ & $3.04 \mathrm{E}+00$ & $0.00 \mathrm{E}+00$ \\
\hline $5.90 \mathrm{E}+02$ & $7.25 \mathrm{E}+01$ & $-1.18 \mathrm{E}-01$ & $7.70 \mathrm{E}+01$ & $1.92 \mathrm{E}+01$ & 6.97E-01 & $0.00 \mathrm{E}+00$ & $0.00 \mathrm{E}+00$ & $0.00 \mathrm{E}+00$ & $0.00 \mathrm{E}+00$ & $3.05 \mathrm{E}+00$ & $0.00 \mathrm{E}+00$ \\
\hline $\operatorname{MAX}=$ & $7.35 \mathrm{E}+01$ & $1.02 \mathrm{E}-01$ & $7.77 \mathrm{E}+01$ & $2.05 E+01$ & $6.97 \mathrm{E}-01$ & $0.00 \mathrm{E}+00$ & $0.00 \mathrm{E}+00$ & $0.00 \mathrm{E}+00$ & $0.00 \mathrm{E}+00$ & $3.05 \mathrm{E}+00$ & $0.00 \mathrm{E}+00$ \\
\hline
\end{tabular}


WSRC-TR-2001-00405

\begin{tabular}{|c|c|c|c|c|c|c|c|c|c|c|c|}
\hline TIME & $\mathrm{HCl} \mathrm{c}(1)$ & $\mathrm{HCl}$ uw (1) & $\mathrm{HCl} \operatorname{lw}(1)$ & $\mathrm{HCl} f(1)$ & Lower N2 (1) & Lower O2 (1) & $\begin{array}{c}\text { Lower CO2 } \\
\text { (1) }\end{array}$ & Lower CO (1) & $\begin{array}{c}\text { Lower HCN } \\
\text { (1) }\end{array}$ & $\begin{array}{l}\text { Lower HCL } \\
\text { (1) }\end{array}$ & $\begin{array}{c}\text { Lower TUHC } \\
\text { (1) }\end{array}$ \\
\hline $0.00 \mathrm{E}+00$ & $.00 \mathrm{E}+00$ & $0.00 \mathrm{E}+00$ & $0.00 \mathrm{E}+00$ & $0.00 \mathrm{E}+00$ & $7.77 \mathrm{E}+01$ & $2.05 \mathrm{E}+01$ & $0.00 \mathrm{E}+00$ & $0.00 \mathrm{E}+00$ & $0.00 \mathrm{E}+00$ & $0.00 \mathrm{E}+00$ & $0.00 \mathrm{E}+00$ \\
\hline $1.00 \mathrm{E}+01$ & $00 \mathrm{E}+00$ & $.00 \mathrm{E}+00$ & $0.00 \mathrm{E}+00$ & $0.00 \mathrm{E}+00$ & $7.77 \mathrm{E}+01$ & $2.05 \mathrm{E}+01$ & $0.00 \mathrm{E}+00$ & $0.00 \mathrm{E}+00$ & $0.00 \mathrm{E}+00$ & $0.00 \mathrm{E}+00$ & $0.00 \mathrm{E}+00$ \\
\hline $2.00 \mathrm{E}+01$ & $0.00 \mathrm{E}+00$ & $0.00 \mathrm{E}+00$ & $0.00 \mathrm{E}+00$ & $0.00 \mathrm{E}+00$ & $7.77 \mathrm{E}+01$ & $2.05 \mathrm{E}+01$ & $0.00 \mathrm{E}+00$ & $0.00 \mathrm{E}+00$ & $0.00 \mathrm{E}+00$ & $0.00 \mathrm{E}+00$ & $0.00 \mathrm{E}+00$ \\
\hline $3.00 \mathrm{E}+01$ & $0.00 \mathrm{E}+00$ & $0.00 \mathrm{E}+00$ & $0.00 \mathrm{E}+00$ & $0.00 \mathrm{E}+00$ & $7.77 \mathrm{E}+01$ & $2.05 \mathrm{E}+01$ & $0.00 \mathrm{E}+00$ & $0.00 \mathrm{E}+00$ & $0.00 \mathrm{E}+00$ & $0.00 \mathrm{E}+00$ & $0.00 \mathrm{E}+00$ \\
\hline $4.00 \mathrm{E}+01$ & $0.00 \mathrm{E}+00$ & $0.00 \mathrm{E}+00$ & $0.00 \mathrm{E}+00$ & $0.00 \mathrm{E}+00$ & $7.77 \mathrm{E}+01$ & $2.05 \mathrm{E}+01$ & $0.00 \mathrm{E}+00$ & $0.00 \mathrm{E}+00$ & $0.00 \mathrm{E}+00$ & $0.00 \mathrm{E}+00$ & $0.00 \mathrm{E}+00$ \\
\hline $5.00 \mathrm{E}+01$ & $0.00 \mathrm{E}+00$ & $0.00 \mathrm{E}+00$ & $0.00 \mathrm{E}+00$ & $0.00 \mathrm{E}+00$ & $7.77 \mathrm{E}+01$ & $2.05 \mathrm{E}+01$ & $0.00 \mathrm{E}+00$ & $0.00 \mathrm{E}+00$ & $0.00 \mathrm{E}+00$ & $0.00 \mathrm{E}+00$ & $0.00 \mathrm{E}+00$ \\
\hline $6.00 \mathrm{E}+01$ & $0.00 \mathrm{E}+00$ & $0.00 \mathrm{E}+00$ & $0.00 \mathrm{E}+00$ & $0.00 \mathrm{E}+00$ & $7.77 \mathrm{E}+01$ & $2.05 \mathrm{E}+01$ & $0.00 \mathrm{E}+00$ & $0.00 \mathrm{E}+00$ & $0.00 \mathrm{E}+00$ & $0.00 \mathrm{E}+00$ & $0.00 \mathrm{E}+00$ \\
\hline $7.00 \mathrm{E}+01$ & $0.00 \mathrm{E}+00$ & $0.00 \mathrm{E}+00$ & $0.00 \mathrm{E}+00$ & $0.00 \mathrm{E}+00$ & $7.77 \mathrm{E}+01$ & $2.05 \mathrm{E}+01$ & $0.00 \mathrm{E}+00$ & $0.00 \mathrm{E}+00$ & $0.00 \mathrm{E}+00$ & $0.00 \mathrm{E}+00$ & $0.00 \mathrm{E}+00$ \\
\hline $8.00 \mathrm{E}+01$ & $0.00 \mathrm{E}+00$ & $0.00 \mathrm{E}+00$ & $0.00 \mathrm{E}+00$ & $0.00 \mathrm{E}+00$ & $7.77 \mathrm{E}+01$ & $2.05 \mathrm{E}+01$ & $0.00 \mathrm{E}+00$ & $0.00 \mathrm{E}+00$ & $.00 \mathrm{E}+00$ & $0.00 \mathrm{E}+00$ & $0.00 \mathrm{E}+00$ \\
\hline $9.00 \mathrm{E}+01$ & $0.00 \mathrm{E}+00$ & $0.00 \mathrm{E}+00$ & $0.00 \mathrm{E}+00$ & $0.00 \mathrm{E}+00$ & $7.77 \mathrm{E}+01$ & $2.05 \mathrm{E}+01$ & $0.00 \mathrm{E}+00$ & $0.00 \mathrm{E}+00$ & $0.00 \mathrm{E}+00$ & $0.00 \mathrm{E}+00$ & $0.00 \mathrm{E}+00$ \\
\hline $1.00 \mathrm{E}+02$ & $0.00 \mathrm{E}+00$ & $0.00 \mathrm{E}+00$ & $0.00 \mathrm{E}+00$ & $0.00 \mathrm{E}+00$ & $7.77 \mathrm{E}+01$ & $2.05 \mathrm{E}+01$ & $0.00 \mathrm{E}+00$ & $0.00 \mathrm{E}+00$ & $0.00 \mathrm{E}+00$ & $0.00 \mathrm{E}+00$ & $0.00 \mathrm{E}+00$ \\
\hline $1.10 \mathrm{E}+02$ & $0.00 \mathrm{E}+00$ & $0.00 \mathrm{E}+00$ & $0.00 \mathrm{E}+00$ & $0.00 \mathrm{E}+00$ & $7.77 \mathrm{E}+01$ & $2.05 \mathrm{E}+01$ & $0.00 \mathrm{E}+00$ & $0.00 \mathrm{E}+00$ & $0.00 \mathrm{E}+00$ & $0.00 \mathrm{E}+00$ & $0.00 \mathrm{E}+00$ \\
\hline $1.20 \mathrm{E}+02$ & $0.00 \mathrm{E}+00$ & $0.00 \mathrm{E}+00$ & $0.00 \mathrm{E}+00$ & $0.00 \mathrm{E}+00$ & $7.77 \mathrm{E}+01$ & $2.05 \mathrm{E}+01$ & $0.00 \mathrm{E}+00$ & $0.00 \mathrm{E}+00$ & $0.00 \mathrm{E}+00$ & $0.00 \mathrm{E}+00$ & $0.00 \mathrm{E}+00$ \\
\hline $1.30 \mathrm{E}+02$ & $0.00 \mathrm{E}+00$ & $0.00 \mathrm{E}+00$ & $0.00 \mathrm{E}+00$ & $0.00 \mathrm{E}+00$ & $7.77 \mathrm{E}+01$ & $2.05 \mathrm{E}+01$ & $0.00 \mathrm{E}+00$ & $0.00 \mathrm{E}+00$ & $0.00 \mathrm{E}+00$ & $0.00 \mathrm{E}+00$ & $0.00 \mathrm{E}+00$ \\
\hline $1.40 \mathrm{E}+02$ & $0.00 \mathrm{E}+00$ & $0.00 \mathrm{E}+00$ & $0.00 \mathrm{E}+00$ & $0.00 \mathrm{E}+00$ & $7.77 \mathrm{E}+01$ & $2.05 \mathrm{E}+01$ & $0.00 \mathrm{E}+00$ & $0.00 \mathrm{E}+00$ & $0.00 \mathrm{E}+00$ & $0.00 \mathrm{E}+00$ & $0.00 \mathrm{E}+00$ \\
\hline $1.50 \mathrm{E}+02$ & $0.00 \mathrm{E}+00$ & $0.00 \mathrm{E}+00$ & $0.00 \mathrm{E}+00$ & $0.00 \mathrm{E}+00$ & $7.77 \mathrm{E}+01$ & $2.05 \mathrm{E}+01$ & $0.00 \mathrm{E}+00$ & $0.00 \mathrm{E}+00$ & $0.00 \mathrm{E}+00$ & $0.00 \mathrm{E}+00$ & $0.00 \mathrm{E}+00$ \\
\hline $1.60 \mathrm{E}+02$ & $0.00 \mathrm{E}+00$ & $0.00 \mathrm{E}+00$ & $0.00 \mathrm{E}+00$ & $0.00 \mathrm{E}+00$ & $7.77 \mathrm{E}+01$ & $2.05 \mathrm{E}+01$ & $0.00 \mathrm{E}+00$ & $0.00 \mathrm{E}+00$ & $0.00 \mathrm{E}+00$ & $0.00 \mathrm{E}+00$ & $0.00 \mathrm{E}+00$ \\
\hline $1.70 \mathrm{E}+02$ & $0.00 \mathrm{E}+00$ & $0.00 \mathrm{E}+00$ & $0.00 \mathrm{E}+00$ & $0.00 \mathrm{E}+00$ & $7.77 \mathrm{E}+01$ & $2.05 \mathrm{E}+01$ & $0.00 \mathrm{E}+00$ & $0.00 \mathrm{E}+00$ & $0.00 \mathrm{E}+00$ & $0.00 \mathrm{E}+00$ & $0.00 \mathrm{E}+00$ \\
\hline $1.80 \mathrm{E}+02$ & $0.00 \mathrm{E}+00$ & $0.00 \mathrm{E}+00$ & $0.00 \mathrm{E}+00$ & $0.00 \mathrm{E}+00$ & $7.77 \mathrm{E}+01$ & $2.05 \mathrm{E}+01$ & $0.00 \mathrm{E}+00$ & $0.00 \mathrm{E}+00$ & $0.00 \mathrm{E}+00$ & $0.00 \mathrm{E}+00$ & $0.00 \mathrm{E}+00$ \\
\hline $1.90 \mathrm{E}+02$ & $0.00 \mathrm{E}+00$ & $0.00 \mathrm{E}+00$ & $0.00 \mathrm{E}+00$ & $0.00 \mathrm{E}+00$ & $7.77 \mathrm{E}+01$ & $2.05 \mathrm{E}+01$ & $0.00 \mathrm{E}+00$ & $0.00 \mathrm{E}+00$ & $0.00 \mathrm{E}+00$ & $0.00 \mathrm{E}+00$ & $0.00 \mathrm{E}+00$ \\
\hline $2.00 \mathrm{E}+02$ & $0.00 \mathrm{E}+00$ & $0.00 \mathrm{E}+00$ & $0.00 \mathrm{E}+00$ & $0.00 \mathrm{E}+00$ & $7.77 \mathrm{E}+01$ & $2.05 \mathrm{E}+01$ & $0.00 \mathrm{E}+00$ & $0.00 \mathrm{E}+00$ & $0.00 \mathrm{E}+00$ & $0.00 \mathrm{E}+00$ & $0.00 \mathrm{E}+00$ \\
\hline $2.10 \mathrm{E}+02$ & $0.00 \mathrm{E}+00$ & $0.00 \mathrm{E}+00$ & $0.00 \mathrm{E}+00$ & $0.00 \mathrm{E}+00$ & $7.78 \mathrm{E}+01$ & $2.05 \mathrm{E}+01$ & $0.00 \mathrm{E}+00$ & $0.00 \mathrm{E}+00$ & $0.00 \mathrm{E}+00$ & $0.00 \mathrm{E}+00$ & $0.00 \mathrm{E}+00$ \\
\hline $2.20 \mathrm{E}+02$ & $0.00 \mathrm{E}+00$ & $0.00 \mathrm{E}+00$ & $0.00 \mathrm{E}+00$ & $0.00 \mathrm{E}+00$ & $7.78 \mathrm{E}+01$ & $2.05 \mathrm{E}+01$ & $0.00 \mathrm{E}+00$ & $0.00 \mathrm{E}+00$ & $0.00 \mathrm{E}+00$ & $0.00 \mathrm{E}+00$ & $0.00 \mathrm{E}+00$ \\
\hline $2.30 \mathrm{E}+02$ & $0.00 \mathrm{E}+00$ & $0.00 \mathrm{E}+00$ & $0.00 \mathrm{E}+00$ & $0.00 \mathrm{E}+00$ & $7.78 \mathrm{E}+01$ & $2.05 \mathrm{E}+01$ & $0.00 \mathrm{E}+00$ & $0.00 \mathrm{E}+00$ & $0.00 \mathrm{E}+00$ & $0.00 \mathrm{E}+00$ & $0.00 \mathrm{E}+00$ \\
\hline $2.40 \mathrm{E}+02$ & $0.00 \mathrm{E}+00$ & $0.00 \mathrm{E}+00$ & $0.00 \mathrm{E}+00$ & $0.00 \mathrm{E}+00$ & $7.78 \mathrm{E}+01$ & $2.05 \mathrm{E}+01$ & $0.00 \mathrm{E}+00$ & $0.00 \mathrm{E}+00$ & $0.00 \mathrm{E}+00$ & $0.00 \mathrm{E}+00$ & $0.00 \mathrm{E}+00$ \\
\hline $2.50 \mathrm{E}+02$ & $0.00 \mathrm{E}+00$ & $0.00 \mathrm{E}+00$ & $0.00 \mathrm{E}+00$ & $0.00 \mathrm{E}+00$ & $7.78 \mathrm{E}+01$ & $2.05 \mathrm{E}+01$ & $0.00 \mathrm{E}+00$ & $0.00 \mathrm{E}+00$ & $0.00 \mathrm{E}+00$ & $0.00 \mathrm{E}+00$ & $0.00 \mathrm{E}+00$ \\
\hline $2.60 \mathrm{E}+02$ & $0.00 \mathrm{E}+00$ & $0.00 \mathrm{E}+00$ & $0.00 \mathrm{E}+00$ & $0.00 \mathrm{E}+00$ & $7.78 \mathrm{E}+01$ & $2.05 \mathrm{E}+01$ & $0.00 \mathrm{E}+00$ & $0.00 \mathrm{E}+00$ & $0.00 \mathrm{E}+00$ & $0.00 \mathrm{E}+00$ & $0.00 \mathrm{E}+00$ \\
\hline $2.70 \mathrm{E}+02$ & $0.00 \mathrm{E}+00$ & $0.00 \mathrm{E}+00$ & $0.00 \mathrm{E}+00$ & $0.00 \mathrm{E}+00$ & $7.78 \mathrm{E}+01$ & $2.05 \mathrm{E}+01$ & $0.00 \mathrm{E}+00$ & $0.00 \mathrm{E}+00$ & $0.00 \mathrm{E}+00$ & $0.00 \mathrm{E}+00$ & $0.00 \mathrm{E}+00$ \\
\hline $2.80 \mathrm{E}+02$ & $0.00 \mathrm{E}+00$ & $0.00 \mathrm{E}+00$ & $0.00 \mathrm{E}+00$ & $0.00 \mathrm{E}+00$ & $7.78 \mathrm{E}+01$ & $2.05 \mathrm{E}+01$ & $0.00 \mathrm{E}+00$ & $0.00 \mathrm{E}+00$ & $0.00 \mathrm{E}+00$ & $.00 \mathrm{E}+00$ & $0.00 \mathrm{E}+00$ \\
\hline $2.90 \mathrm{E}+02$ & $0.00 \mathrm{E}+00$ & $0.00 \mathrm{E}+00$ & $0.00 \mathrm{E}+00$ & $0.00 \mathrm{E}+00$ & $7.78 \mathrm{E}+01$ & $2.05 \mathrm{E}+01$ & $0.00 \mathrm{E}+00$ & $0.00 \mathrm{E}+00$ & $0.00 \mathrm{E}+00$ & $0.00 \mathrm{E}+00$ & $0.00 \mathrm{E}+00$ \\
\hline $3.00 \mathrm{E}+02$ & $0.00 \mathrm{E}+00$ & $0.00 \mathrm{E}+00$ & $0.00 \mathrm{E}+00$ & $0.00 \mathrm{E}+00$ & $7.78 \mathrm{E}+01$ & $2.05 \mathrm{E}+01$ & $0.00 \mathrm{E}+00$ & $0.00 \mathrm{E}+00$ & $0.00 \mathrm{E}+00$ & $0.00 \mathrm{E}+00$ & $0.00 \mathrm{E}+00$ \\
\hline $3.10 \mathrm{E}+02$ & $0.00 \mathrm{E}+00$ & $0.00 \mathrm{E}+00$ & $0.00 \mathrm{E}+00$ & $0.00 \mathrm{E}+00$ & $7.78 \mathrm{E}+01$ & $2.05 \mathrm{E}+01$ & $0.00 \mathrm{E}+00$ & $0.00 \mathrm{E}+00$ & $0.00 \mathrm{E}+00$ & $0.00 \mathrm{E}+00$ & $0.00 \mathrm{E}+00$ \\
\hline $3.20 \mathrm{E}+02$ & $0.00 \mathrm{E}+00$ & $0.00 \mathrm{E}+00$ & $0.00 \mathrm{E}+00$ & $0.00 \mathrm{E}+00$ & $7.78 \mathrm{E}+01$ & $2.05 \mathrm{E}+01$ & $0.00 \mathrm{E}+00$ & $0.00 \mathrm{E}+00$ & $0.00 \mathrm{E}+00$ & $0.00 \mathrm{E}+00$ & $0.00 \mathrm{E}+00$ \\
\hline $3.30 \mathrm{E}+02$ & $0.00 \mathrm{E}+00$ & $0.00 \mathrm{E}+00$ & $0.00 \mathrm{E}+00$ & $0.00 \mathrm{E}+00$ & $7.78 \mathrm{E}+01$ & $2.05 \mathrm{E}+01$ & $0.00 \mathrm{E}+00$ & $0.00 \mathrm{E}+00$ & $0.00 \mathrm{E}+00$ & $0.00 \mathrm{E}+00$ & $0.00 \mathrm{E}+00$ \\
\hline $3.40 \mathrm{E}+02$ & $0.00 \mathrm{E}+00$ & $0.00 \mathrm{E}+00$ & $0.00 \mathrm{E}+00$ & $0.00 \mathrm{E}+00$ & $7.78 \mathrm{E}+01$ & $2.05 \mathrm{E}+01$ & $0.00 \mathrm{E}+00$ & $0.00 \mathrm{E}+00$ & $0.00 \mathrm{E}+00$ & $0.00 \mathrm{E}+00$ & $0.00 \mathrm{E}+00$ \\
\hline $3.50 \mathrm{E}+02$ & $0.00 \mathrm{E}+00$ & $0.00 \mathrm{E}+00$ & $0.00 \mathrm{E}+00$ & $0.00 \mathrm{E}+00$ & $7.78 \mathrm{E}+01$ & $2.05 \mathrm{E}+01$ & $0.00 \mathrm{E}+00$ & $0.00 \mathrm{E}+00$ & $0.00 \mathrm{E}+00$ & $0.00 \mathrm{E}+00$ & $0.00 \mathrm{E}+00$ \\
\hline $3.60 \mathrm{E}+02$ & $0.00 \mathrm{E}+00$ & $0.00 \mathrm{E}+00$ & $0.00 \mathrm{E}+00$ & $0.00 \mathrm{E}+00$ & $7.78 \mathrm{E}+01$ & $2.05 \mathrm{E}+01$ & $0.00 \mathrm{E}+00$ & $0.00 \mathrm{E}+00$ & $0.00 \mathrm{E}+00$ & $0.00 \mathrm{E}+00$ & $0.00 \mathrm{E}+00$ \\
\hline $3.70 \mathrm{E}+02$ & $0.00 \mathrm{E}+00$ & $0.00 \mathrm{E}+00$ & $0.00 \mathrm{E}+00$ & $0.00 \mathrm{E}+00$ & $7.78 \mathrm{E}+01$ & $2.05 \mathrm{E}+01$ & $0.00 \mathrm{E}+00$ & $0.00 \mathrm{E}+00$ & $0.00 \mathrm{E}+00$ & $0.00 \mathrm{E}+00$ & $0.00 \mathrm{E}+00$ \\
\hline $3.80 \mathrm{E}+02$ & $0.00 \mathrm{E}+00$ & $0.00 \mathrm{E}+00$ & $0.00 \mathrm{E}+00$ & $0.00 \mathrm{E}+00$ & $7.78 \mathrm{E}+01$ & $2.05 \mathrm{E}+01$ & $0.00 \mathrm{E}+00$ & $0.00 \mathrm{E}+00$ & $0.00 \mathrm{E}+00$ & $0.00 \mathrm{E}+00$ & $0.00 \mathrm{E}+00$ \\
\hline $3.90 \mathrm{E}+02$ & $0.00 \mathrm{E}+00$ & $0.00 \mathrm{E}+00$ & $0.00 \mathrm{E}+00$ & $0.00 \mathrm{E}+00$ & $7.79 \mathrm{E}+01$ & $2.05 \mathrm{E}+01$ & $0.00 \mathrm{E}+00$ & $0.00 \mathrm{E}+00$ & $0.00 \mathrm{E}+00$ & $0.00 \mathrm{E}+00$ & $0.00 \mathrm{E}+00$ \\
\hline $4.00 \mathrm{E}+02$ & $0.00 \mathrm{E}+00$ & $0.00 \mathrm{E}+00$ & $0.00 \mathrm{E}+00$ & $0.00 \mathrm{E}+00$ & $7.79 \mathrm{E}+01$ & $2.05 \mathrm{E}+01$ & $0.00 \mathrm{E}+00$ & $0.00 \mathrm{E}+00$ & $0.00 \mathrm{E}+00$ & $0.00 \mathrm{E}+00$ & $0.00 \mathrm{E}+00$ \\
\hline $4.10 \mathrm{E}+02$ & $0.00 \mathrm{E}+00$ & $0.00 \mathrm{E}+00$ & $0.00 \mathrm{E}+00$ & $0.00 \mathrm{E}+00$ & $7.79 \mathrm{E}+01$ & $2.05 \mathrm{E}+01$ & $0.00 \mathrm{E}+00$ & $0.00 \mathrm{E}+00$ & $0.00 \mathrm{E}+00$ & $0.00 \mathrm{E}+00$ & $0.00 \mathrm{E}+00$ \\
\hline $4.20 \mathrm{E}+02$ & $0.00 \mathrm{E}+00$ & $0.00 \mathrm{E}+00$ & $0.00 \mathrm{E}+00$ & $0.00 \mathrm{E}+00$ & $7.79 \mathrm{E}+01$ & $2.05 \mathrm{E}+01$ & $0.00 \mathrm{E}+00$ & $0.00 \mathrm{E}+00$ & $0.00 \mathrm{E}+00$ & $0.00 \mathrm{E}+00$ & $0.00 \mathrm{E}+00$ \\
\hline $4.30 \mathrm{E}+02$ & $0.00 \mathrm{E}+00$ & $0.00 \mathrm{E}+00$ & $0.00 \mathrm{E}+00$ & $0.00 \mathrm{E}+00$ & $7.79 \mathrm{E}+01$ & $2.05 \mathrm{E}+01$ & $0.00 \mathrm{E}+00$ & $0.00 \mathrm{E}+00$ & $0.00 \mathrm{E}+00$ & $0.00 \mathrm{E}+00$ & $0.00 \mathrm{E}+00$ \\
\hline $4.40 \mathrm{E}+02$ & $0.00 \mathrm{E}+00$ & $0.00 \mathrm{E}+00$ & $0.00 \mathrm{E}+00$ & $0.00 \mathrm{E}+00$ & $7.79 \mathrm{E}+01$ & $2.05 \mathrm{E}+01$ & $0.00 \mathrm{E}+00$ & $0.00 \mathrm{E}+00$ & $0.00 \mathrm{E}+00$ & $0.00 \mathrm{E}+00$ & $0.00 \mathrm{E}+00$ \\
\hline $4.50 \mathrm{E}+02$ & $0.00 \mathrm{E}+00$ & $0.00 \mathrm{E}+00$ & $0.00 \mathrm{E}+00$ & $0.00 \mathrm{E}+00$ & $7.79 \mathrm{E}+01$ & $2.05 \mathrm{E}+01$ & $0.00 \mathrm{E}+00$ & $0.00 \mathrm{E}+00$ & $0.00 \mathrm{E}+00$ & $0.00 \mathrm{E}+00$ & $0.00 \mathrm{E}+00$ \\
\hline $4.60 \mathrm{E}+02$ & $0.00 \mathrm{E}+00$ & $0.00 \mathrm{E}+00$ & $0.00 \mathrm{E}+00$ & $0.00 \mathrm{E}+00$ & $7.79 \mathrm{E}+01$ & $2.05 \mathrm{E}+01$ & $0.00 \mathrm{E}+00$ & $0.00 \mathrm{E}+00$ & $0.00 \mathrm{E}+00$ & $0.00 \mathrm{E}+00$ & $0.00 \mathrm{E}+00$ \\
\hline $4.70 \mathrm{E}+02$ & $0.00 \mathrm{E}+00$ & $0.00 \mathrm{E}+00$ & $0.00 \mathrm{E}+00$ & $0.00 \mathrm{E}+00$ & $7.79 \mathrm{E}+01$ & $2.05 \mathrm{E}+01$ & $0.00 \mathrm{E}+00$ & $0.00 \mathrm{E}+00$ & $0.00 \mathrm{E}+00$ & $0.00 \mathrm{E}+00$ & $0.00 \mathrm{E}+00$ \\
\hline $4.80 \mathrm{E}+02$ & $0.00 \mathrm{E}+00$ & $0.00 \mathrm{E}+00$ & $0.00 \mathrm{E}+00$ & $0.00 \mathrm{E}+00$ & $7.80 \mathrm{E}+01$ & $2.05 \mathrm{E}+01$ & $0.00 \mathrm{E}+00$ & $0.00 \mathrm{E}+00$ & $0.00 \mathrm{E}+00$ & $0.00 \mathrm{E}+00$ & $0.00 \mathrm{E}+00$ \\
\hline $4.90 \mathrm{E}+02$ & $0.00 \mathrm{E}+00$ & $0.00 \mathrm{E}+00$ & $0.00 \mathrm{E}+00$ & $0.00 \mathrm{E}+00$ & $7.80 \mathrm{E}+01$ & $2.05 \mathrm{E}+01$ & $0.00 \mathrm{E}+00$ & $0.00 \mathrm{E}+00$ & $0.00 \mathrm{E}+00$ & $0.00 \mathrm{E}+00$ & $0.00 \mathrm{E}+00$ \\
\hline $5.00 \mathrm{E}+02$ & $0.00 \mathrm{E}+00$ & $0.00 \mathrm{E}+00$ & $0.00 \mathrm{E}+00$ & $0.00 \mathrm{E}+00$ & $7.80 \mathrm{E}+01$ & $2.05 \mathrm{E}+01$ & $0.00 \mathrm{E}+00$ & $0.00 \mathrm{E}+00$ & $0.00 \mathrm{E}+00$ & $0.00 \mathrm{E}+00$ & $0.00 \mathrm{E}+00$ \\
\hline $5.10 \mathrm{E}+02$ & $0.00 \mathrm{E}+00$ & $0.00 \mathrm{E}+00$ & $0.00 \mathrm{E}+00$ & $0.00 \mathrm{E}+00$ & $7.80 \mathrm{E}+01$ & $2.05 \mathrm{E}+01$ & $0.00 \mathrm{E}+00$ & $0.00 \mathrm{E}+00$ & $0.00 \mathrm{E}+00$ & $0.00 \mathrm{E}+00$ & $0.00 \mathrm{E}+00$ \\
\hline $5.20 \mathrm{E}+02$ & $0.00 \mathrm{E}+00$ & $0.00 \mathrm{E}+00$ & $0.00 \mathrm{E}+00$ & $0.00 \mathrm{E}+00$ & $7.80 \mathrm{E}+01$ & $2.05 \mathrm{E}+01$ & $0.00 \mathrm{E}+00$ & $0.00 \mathrm{E}+00$ & $0.00 \mathrm{E}+00$ & $0.00 \mathrm{E}+00$ & $0.00 \mathrm{E}+00$ \\
\hline $5.30 \mathrm{E}+02$ & $0.00 \mathrm{E}+00$ & $0.00 \mathrm{E}+00$ & $0.00 \mathrm{E}+00$ & $0.00 \mathrm{E}+00$ & $7.80 \mathrm{E}+01$ & $2.05 \mathrm{E}+01$ & $0.00 \mathrm{E}+00$ & $0.00 \mathrm{E}+00$ & $0.00 \mathrm{E}+00$ & $0.00 \mathrm{E}+00$ & $0.00 \mathrm{E}+00$ \\
\hline $5.40 \mathrm{E}+02$ & $0.00 \mathrm{E}+00$ & $0.00 \mathrm{E}+00$ & $0.00 \mathrm{E}+00$ & $0.00 \mathrm{E}+00$ & $7.80 \mathrm{E}+01$ & $2.05 \mathrm{E}+01$ & $0.00 \mathrm{E}+00$ & $0.00 \mathrm{E}+00$ & $0.00 \mathrm{E}+00$ & $0.00 \mathrm{E}+00$ & $0.00 \mathrm{E}+00$ \\
\hline $5.50 \mathrm{E}+02$ & $0.00 \mathrm{E}+00$ & $0.00 \mathrm{E}+00$ & $0.00 \mathrm{E}+00$ & $0.00 \mathrm{E}+00$ & $7.80 \mathrm{E}+01$ & $2.05 \mathrm{E}+01$ & $0.00 \mathrm{E}+00$ & $0.00 \mathrm{E}+00$ & $0.00 \mathrm{E}+00$ & $0.00 \mathrm{E}+00$ & $0.00 \mathrm{E}+00$ \\
\hline $5.60 \mathrm{E}+02$ & $0.00 \mathrm{E}+00$ & $0.00 \mathrm{E}+00$ & $0.00 \mathrm{E}+00$ & $0.00 \mathrm{E}+00$ & $7.81 \mathrm{E}+01$ & $2.05 \mathrm{E}+01$ & $0.00 \mathrm{E}+00$ & $0.00 \mathrm{E}+00$ & $0.00 \mathrm{E}+00$ & $0.00 \mathrm{E}+00$ & $0.00 \mathrm{E}+00$ \\
\hline $5.70 \mathrm{E}+02$ & $0.00 \mathrm{E}+00$ & $0.00 \mathrm{E}+00$ & $0.00 \mathrm{E}+00$ & $0.00 \mathrm{E}+00$ & $7.81 \mathrm{E}+01$ & $2.05 \mathrm{E}+01$ & $0.00 \mathrm{E}+00$ & $0.00 \mathrm{E}+00$ & $0.00 \mathrm{E}+00$ & $0.00 \mathrm{E}+00$ & $0.00 \mathrm{E}+00$ \\
\hline $5.80 \mathrm{E}+02$ & $0.00 \mathrm{E}+00$ & $0.00 \mathrm{E}+00$ & $0.00 \mathrm{E}+00$ & $0.00 \mathrm{E}+00$ & $7.81 \mathrm{E}+01$ & $2.05 \mathrm{E}+01$ & $0.00 \mathrm{E}+00$ & $0.00 \mathrm{E}+00$ & $0.00 \mathrm{E}+00$ & $0.00 \mathrm{E}+00$ & $0.00 \mathrm{E}+00$ \\
\hline $5.90 \mathrm{E}+02$ & $0.00 \mathrm{E}+00$ & $0.00 \mathrm{E}+00$ & $0.00 \mathrm{E}+00$ & $0.00 \mathrm{E}+00$ & $7.81 \mathrm{E}+01$ & $2.05 \mathrm{E}+01$ & $0.00 \mathrm{E}+00$ & $0.00 \mathrm{E}+00$ & $0.00 \mathrm{E}+00$ & $0.00 \mathrm{E}+00$ & $0.00 \mathrm{E}+00$ \\
\hline $\operatorname{MAX}=$ & $0.00 \mathrm{E}+00$ & $0.00 \mathrm{E}+00$ & $0.00 \mathrm{E}+00$ & $0.00 \mathrm{E}+00$ & $7.81 \mathrm{E}+01$ & $2.05 \mathrm{E}+01$ & $0.00 \mathrm{E}+00$ & $0.00 \mathrm{E}+00$ & $0.00 \mathrm{E}+00$ & $0.00 \mathrm{E}+00$ & $0.00 \mathrm{E}+00$ \\
\hline
\end{tabular}


WSRC-TR-2001-00405

\begin{tabular}{|c|c|c|c|c|c|c|c|c|c|c|}
\hline TIME & $\begin{array}{l}\text { Dwer H2O } \\
\text { (1) }\end{array}$ & Lower OD (1) & $\mathrm{HCl} \mathrm{c} \mathrm{(1)}$ & $\mathrm{HCl}$ uw (1) & $\mathrm{HCl}$ Iw (1) & $\mathrm{HCl} f(1)$ & $\begin{array}{c}\text { Upper Inflow } \\
\text { 1-Outside (1) }\end{array}$ & $\begin{array}{c}\text { Upper } \\
\text { Outflow 1- } \\
\text { Outside (1) }\end{array}$ & $\begin{array}{l}\text { Lower Inflow } \\
\text { 1-Outside (1) }\end{array}$ & $\begin{array}{c}\text { Lower } \\
\text { Outflow 1- } \\
\text { Outside (1) }\end{array}$ \\
\hline $0.00 \mathrm{E}+00$ & $1.75 \mathrm{E}+00$ & $0.00 \mathrm{E}+00$ & $0.00 \mathrm{E}+00$ & $0.00 \mathrm{E}+00$ & $0.00 \mathrm{E}+00$ & $0.00 \mathrm{E}+00$ & $0.00 \mathrm{E}+00$ & $0.00 \mathrm{E}+00$ & $4.00 \mathrm{E}-18$ & $0.00 \mathrm{E}+00$ \\
\hline $1.00 \mathrm{E}+01$ & $1.75 \mathrm{E}+00$ & $0.00 \mathrm{E}+00$ & $0.00 \mathrm{E}+00$ & $0.00 \mathrm{E}+00$ & $0.00 \mathrm{E}+00$ & $0.00 \mathrm{E}+00$ & $0.00 \mathrm{E}+00$ & $0.00 \mathrm{E}+00$ & $0.00 \mathrm{E}+00$ & 5.52E-02 \\
\hline $2.00 \mathrm{E}+01$ & $1.75 \mathrm{E}+00$ & $0.00 \mathrm{E}+00$ & $0.00 \mathrm{E}+00$ & $0.00 \mathrm{E}+00$ & $0.00 \mathrm{E}+00$ & $0.00 \mathrm{E}+00$ & $0.00 \mathrm{E}+00$ & $0.00 \mathrm{E}+00$ & $0.00 \mathrm{E}+00$ & $1.11 \mathrm{E}-01$ \\
\hline $3.00 \mathrm{E}+01$ & $1.75 \mathrm{E}+00$ & $0.00 \mathrm{E}+00$ & $0.00 \mathrm{E}+00$ & $0.00 \mathrm{E}+00$ & $0.00 \mathrm{E}+00$ & $0.00 \mathrm{E}+00$ & $0.00 \mathrm{E}+00$ & $0.00 \mathrm{E}+00$ & $0.00 \mathrm{E}+00$ & $1.65 \mathrm{E}-01$ \\
\hline $4.00 \mathrm{E}+01$ & $1.75 \mathrm{E}+00$ & $0.00 \mathrm{E}+00$ & $0.00 \mathrm{E}+00$ & $0.00 \mathrm{E}+00$ & $0.00 \mathrm{E}+00$ & $0.00 \mathrm{E}+00$ & $0.00 \mathrm{E}+00$ & $0.00 \mathrm{E}+00$ & $0.00 \mathrm{E}+00$ & $2.18 \mathrm{E}-01$ \\
\hline $5.00 \mathrm{E}+01$ & $1.75 \mathrm{E}+00$ & $0.00 \mathrm{E}+00$ & $0.00 \mathrm{E}+00$ & $0.00 \mathrm{E}+00$ & $0.00 \mathrm{E}+00$ & $0.00 \mathrm{E}+00$ & $0.00 \mathrm{E}+00$ & $0.00 \mathrm{E}+00$ & $0.00 \mathrm{E}+00$ & $2.70 \mathrm{E}-01$ \\
\hline $6.00 \mathrm{E}+01$ & $1.75 \mathrm{E}+00$ & $0.00 \mathrm{E}+00$ & $0.00 \mathrm{E}+00$ & $0.00 \mathrm{E}+00$ & $0.00 \mathrm{E}+00$ & $0.00 \mathrm{E}+00$ & $.00 \mathrm{E}+00$ & $0.00 \mathrm{E}+00$ & $0.00 \mathrm{E}+00$ & 3.22E-01 \\
\hline $7.00 \mathrm{E}+01$ & $1.75 \mathrm{E}+00$ & $.00 \mathrm{E}+00$ & $0.00 \mathrm{E}+00$ & $0.00 \mathrm{E}+00$ & $0.00 \mathrm{E}+00$ & $0.00 \mathrm{E}+00$ & $00 \mathrm{E}+00$ & $0.00 \mathrm{E}+00$ & $0.00 \mathrm{E}+00$ & 3.68E-01 \\
\hline $8.00 \mathrm{E}+01$ & $1.75 \mathrm{E}+00$ & $.00 \mathrm{E}+00$ & $0.00 \mathrm{E}+00$ & $0.00 \mathrm{E}+00$ & $0.00 \mathrm{E}+00$ & $0.00 \mathrm{E}+00$ & $.00 \mathrm{E}+00$ & $0.00 \mathrm{E}+00$ & $0.00 \mathrm{E}+00$ & $4.09 \mathrm{E}-01$ \\
\hline $9.00 \mathrm{E}+01$ & $1.75 \mathrm{E}+00$ & $0.00 \mathrm{E}+00$ & $0.00 \mathrm{E}+00$ & $0.00 \mathrm{E}+00$ & $0.00 \mathrm{E}+00$ & $0.00 \mathrm{E}+00$ & $.00 \mathrm{E}+00$ & $0.00 \mathrm{E}+00$ & $0.00 \mathrm{E}+00$ & 4.47E-01 \\
\hline $1.00 \mathrm{E}+02$ & $1.75 \mathrm{E}+00$ & $0.00 \mathrm{E}+00$ & $0.00 \mathrm{E}+00$ & $0.00 \mathrm{E}+00$ & $0.00 \mathrm{E}+00$ & $0.00 \mathrm{E}+00$ & $0.00 \mathrm{E}+00$ & $0.00 \mathrm{E}+00$ & $0.00 \mathrm{E}+00$ & $4.83 \mathrm{E}-01$ \\
\hline $1.10 \mathrm{E}+02$ & $1.75 \mathrm{E}+00$ & $0.00 \mathrm{E}+00$ & $0.00 \mathrm{E}+00$ & $0.00 \mathrm{E}+00$ & $0.00 \mathrm{E}+00$ & $0.00 \mathrm{E}+00$ & $0.00 \mathrm{E}+00$ & $0.00 \mathrm{E}+00$ & $0.00 \mathrm{E}+00$ & $5.17 \mathrm{E}-01$ \\
\hline $1.20 \mathrm{E}+02$ & $1.75 \mathrm{E}+00$ & $0.00 \mathrm{E}+00$ & $0.00 \mathrm{E}+00$ & $0.00 \mathrm{E}+00$ & $0.00 \mathrm{E}+00$ & $0.00 \mathrm{E}+00$ & $0.00 \mathrm{E}+00$ & $0.00 \mathrm{E}+00$ & $0.00 \mathrm{E}+00$ & $5.50 \mathrm{E}-01$ \\
\hline $1.30 \mathrm{E}+02$ & $1.75 \mathrm{E}+00$ & $0.00 \mathrm{E}+00$ & $0.00 \mathrm{E}+00$ & $0.00 \mathrm{E}+00$ & $0.00 \mathrm{E}+00$ & $0.00 \mathrm{E}+00$ & $0.00 \mathrm{E}+00$ & $0.00 \mathrm{E}+00$ & $0.00 \mathrm{E}+00$ & $5.74 \mathrm{E}-01$ \\
\hline $1.40 \mathrm{E}+02$ & $1.75 \mathrm{E}+00$ & $0.00 \mathrm{E}+00$ & $0.00 \mathrm{E}+00$ & $0.00 \mathrm{E}+00$ & $0.00 \mathrm{E}+00$ & $0.00 \mathrm{E}+00$ & $0.00 \mathrm{E}+00$ & $0.00 \mathrm{E}+00$ & $0.00 \mathrm{E}+00$ & 5.84E-01 \\
\hline $1.50 \mathrm{E}+02$ & $1.75 \mathrm{E}+00$ & $0.00 \mathrm{E}+00$ & $0.00 \mathrm{E}+00$ & $0.00 \mathrm{E}+00$ & $0.00 \mathrm{E}+00$ & $0.00 \mathrm{E}+00$ & $0.00 \mathrm{E}+00$ & $0.00 \mathrm{E}+00$ & $0.00 \mathrm{E}+00$ & $5.86 \mathrm{E}-01$ \\
\hline $1.60 \mathrm{E}+02$ & $1.75 \mathrm{E}+00$ & $0.00 \mathrm{E}+00$ & $0.00 \mathrm{E}+00$ & $0.00 \mathrm{E}+00$ & $0.00 \mathrm{E}+00$ & $0.00 \mathrm{E}+00$ & $.00 \mathrm{E}+00$ & $0.00 \mathrm{E}+00$ & $0.00 \mathrm{E}+00$ & 5.82E-01 \\
\hline $1.70 \mathrm{E}+02$ & $1.75 \mathrm{E}+00$ & $0.00 \mathrm{E}+00$ & $0.00 \mathrm{E}+00$ & $0.00 \mathrm{E}+00$ & $0.00 \mathrm{E}+00$ & $0.00 \mathrm{E}+00$ & $0.00 \mathrm{E}+00$ & $0.00 \mathrm{E}+00$ & $0.00 \mathrm{E}+00$ & $5.72 \mathrm{E}-01$ \\
\hline $1.80 \mathrm{E}+02$ & $1.75 \mathrm{E}+00$ & $0.00 \mathrm{E}+00$ & $0.00 \mathrm{E}+00$ & $0.00 \mathrm{E}+00$ & $0.00 \mathrm{E}+00$ & $0.00 \mathrm{E}+00$ & $0.00 \mathrm{E}+00$ & $0.00 \mathrm{E}+00$ & $0.00 \mathrm{E}+00$ & $5.60 \mathrm{E}-01$ \\
\hline $1.90 \mathrm{E}+02$ & $1.75 \mathrm{E}+00$ & $0.00 \mathrm{E}+00$ & $0.00 \mathrm{E}+00$ & $0.00 \mathrm{E}+00$ & $0.00 \mathrm{E}+00$ & $0.00 \mathrm{E}+00$ & $0.00 \mathrm{E}+00$ & $0.00 \mathrm{E}+00$ & $0.00 \mathrm{E}+00$ & $5.38 \mathrm{E}-01$ \\
\hline $2.00 \mathrm{E}+02$ & $1.75 \mathrm{E}+00$ & $0.00 \mathrm{E}+00$ & $0.00 \mathrm{E}+00$ & $0.00 \mathrm{E}+00$ & $0.00 \mathrm{E}+00$ & $0.00 \mathrm{E}+00$ & $0.00 \mathrm{E}+00$ & $0.00 \mathrm{E}+00$ & $0.00 \mathrm{E}+00$ & $5.03 \mathrm{E}-01$ \\
\hline $2.10 \mathrm{E}+02$ & $1.75 \mathrm{E}+00$ & $0.00 \mathrm{E}+00$ & $0.00 \mathrm{E}+00$ & $0.00 \mathrm{E}+00$ & $0.00 \mathrm{E}+00$ & $0.00 \mathrm{E}+00$ & $0.00 \mathrm{E}+00$ & $0.00 \mathrm{E}+00$ & $0.00 \mathrm{E}+00$ & $4.56 \mathrm{E}-01$ \\
\hline $2.20 \mathrm{E}+02$ & $1.75 \mathrm{E}+00$ & $0.00 \mathrm{E}+00$ & $0.00 \mathrm{E}+00$ & $0.00 \mathrm{E}+00$ & $0.00 \mathrm{E}+00$ & $0.00 \mathrm{E}+00$ & $0.00 \mathrm{E}+00$ & $0.00 \mathrm{E}+00$ & $0.00 \mathrm{E}+00$ & $4.00 \mathrm{E}-01$ \\
\hline $2.30 \mathrm{E}+02$ & $1.75 \mathrm{E}+00$ & $0.00 \mathrm{E}+00$ & $0.00 \mathrm{E}+00$ & $0.00 \mathrm{E}+00$ & $0.00 \mathrm{E}+00$ & $0.00 \mathrm{E}+00$ & $0.00 \mathrm{E}+00$ & $0.00 \mathrm{E}+00$ & $0.00 \mathrm{E}+00$ & 3.36E-01 \\
\hline $2.40 \mathrm{E}+02$ & $1.75 \mathrm{E}+00$ & $0.00 \mathrm{E}+00$ & $0.00 \mathrm{E}+00$ & $0.00 \mathrm{E}+00$ & $0.00 \mathrm{E}+00$ & $0.00 \mathrm{E}+00$ & $0.00 \mathrm{E}+00$ & $0.00 \mathrm{E}+00$ & $0.00 \mathrm{E}+00$ & $\mathrm{E}-01$ \\
\hline $2.50 \mathrm{E}+02$ & $1.75 \mathrm{E}+00$ & $0.00 \mathrm{E}+00$ & $0.00 \mathrm{E}+00$ & $E+00$ & 0 & 0.00 & $E+00$ & $\mathrm{E}+00$ & & -01 \\
\hline $2.60 \mathrm{E}+02$ & $1.75 \mathrm{E}+00$ & $0.00 \mathrm{E}+00$ & $0.00 \mathrm{E}+00$ & $0.00 \mathrm{E}+00$ & $0.00 \mathrm{E}+00$ & $0.00 \mathrm{E}+00$ & $0.00 \mathrm{E}+00$ & $0.00 \mathrm{E}+00$ & $\mathrm{E}+00$ & 1.34E-01 \\
\hline $2.70 \mathrm{E}+02$ & $1.75 \mathrm{E}+00$ & $0.00 \mathrm{E}+00$ & $0.00 \mathrm{E}+00$ & $0.00 \mathrm{E}+00$ & $0.00 \mathrm{E}+00$ & $0.00 \mathrm{E}+00$ & $00 \mathrm{E}+00$ & $0.00 \mathrm{E}+00$ & $0.00 \mathrm{E}+00$ & $9.22 \mathrm{E}-02$ \\
\hline $2.80 \mathrm{E}+02$ & $75 \mathrm{E}+00$ & $E+00$ & +00 & $0.00 \mathrm{E}+00$ & $0.00 \mathrm{E}+00$ & $0.00 \mathrm{E}+00$ & $E+00$ & $E+00$ & $E+00$ & $\mathrm{E}-02$ \\
\hline $2.90 \mathrm{E}+02$ & $1.75 \mathrm{E}+00$ & $\mathrm{OE}+00$ & $0.00 \mathrm{E}+00$ & $0.00 \mathrm{E}+00$ & $0.00 \mathrm{E}+00$ & $0.00 \mathrm{E}+00$ & $0.00 \mathrm{E}+00$ & $0.00 \mathrm{E}+00$ & $0.00 \mathrm{E}+00$ & 3.88E-02 \\
\hline $3.00 \mathrm{E}+02$ & $1.75 \mathrm{E}+00$ & $0.00 \mathrm{E}+00$ & $0.00 \mathrm{E}+00$ & $0.00 \mathrm{E}+00$ & $0.00 \mathrm{E}+00$ & $0.00 \mathrm{E}+00$ & $0.00 \mathrm{E}+00$ & $0.00 \mathrm{E}+00$ & $0.00 \mathrm{E}+00$ & 1.73E-02 \\
\hline $3.10 \mathrm{E}+02$ & $1.75 \mathrm{E}+00$ & $0.00 \mathrm{E}+00$ & $0.00 \mathrm{E}+00$ & $0.00 \mathrm{E}+00$ & $0.00 \mathrm{E}+00$ & $0.00 \mathrm{E}+00$ & $0.00 \mathrm{E}+00$ & $0.00 \mathrm{E}+00$ & $2.49 \mathrm{E}-03$ & $0.00 \mathrm{E}+00$ \\
\hline $3.20 \mathrm{E}+02$ & $1.75 \mathrm{E}+00$ & $0.00 \mathrm{E}+00$ & $0.00 \mathrm{E}+00$ & $0.00 \mathrm{E}+00$ & $0.00 \mathrm{E}+00$ & $0.00 \mathrm{E}+00$ & $0.00 \mathrm{E}+00$ & $0.00 \mathrm{E}+00$ & $1.81 \mathrm{E}-02$ & $0.00 \mathrm{E}+00$ \\
\hline $3.30 \mathrm{E}+02$ & $1.74 \mathrm{E}+00$ & $0.00 \mathrm{E}+00$ & $0.00 \mathrm{E}+00$ & $0.00 \mathrm{E}+00$ & $0.00 \mathrm{E}+00$ & $0.00 \mathrm{E}+00$ & $0.00 \mathrm{E}+00$ & $0.00 \mathrm{E}+00$ & $2 \mathrm{E}-02$ & $0.00 \mathrm{E}+00$ \\
\hline $3.40 \mathrm{E}+02$ & $1.73 \mathrm{E}+00$ & $0.00 \mathrm{E}+00$ & $0.00 \mathrm{E}+00$ & $0.00 \mathrm{E}+00$ & $0.00 \mathrm{E}+00$ & $0.00 \mathrm{E}+00$ & $0.00 \mathrm{E}+00$ & $0.00 \mathrm{E}+00$ & $4.78 \mathrm{E}-02$ & $0.00 \mathrm{E}+00$ \\
\hline $3.50 \mathrm{E}+02$ & $1.72 \mathrm{E}+00$ & $0.00 \mathrm{E}+00$ & $0.00 \mathrm{E}+00$ & $0.00 \mathrm{E}+00$ & $0.00 \mathrm{E}+00$ & $0.00 \mathrm{E}+00$ & $0.00 \mathrm{E}+00$ & $0.00 \mathrm{E}+00$ & $6.20 \mathrm{E}-02$ & $.00 \mathrm{E}+00$ \\
\hline $3.60 \mathrm{E}+02$ & $1.71 \mathrm{E}+00$ & $0.00 \mathrm{E}+00$ & $0.00 \mathrm{E}+00$ & $0.00 \mathrm{E}+00$ & $0.00 \mathrm{E}+00$ & $0.00 \mathrm{E}+00$ & $0.00 \mathrm{E}+00$ & $0.00 \mathrm{E}+00$ & 7.57E-02 & $0.00 \mathrm{E}+00$ \\
\hline $3.70 \mathrm{E}+02$ & $1.70 \mathrm{E}+00$ & $0.00 \mathrm{E}+00$ & $0.00 \mathrm{E}+00$ & $0.00 \mathrm{E}+00$ & $0.00 \mathrm{E}+00$ & $0.00 \mathrm{E}+00$ & $.00 \mathrm{E}+00$ & $0.00 \mathrm{E}+00$ & $7.84 \mathrm{E}-02$ & $0.00 \mathrm{E}+00$ \\
\hline $3.80 \mathrm{E}+02$ & $1.68 \mathrm{E}+00$ & $0.00 \mathrm{E}+00$ & $0.00 \mathrm{E}+00$ & $0.00 \mathrm{E}+00$ & $0.00 \mathrm{E}+00$ & $0.00 \mathrm{E}+00$ & $0.00 \mathrm{E}+00$ & $0.00 \mathrm{E}+00$ & $7.45 \mathrm{E}-02$ & $0.00 \mathrm{E}+00$ \\
\hline $3.90 \mathrm{E}+02$ & $1.67 \mathrm{E}+00$ & $0.00 \mathrm{E}+00$ & $0.00 \mathrm{E}+00$ & $0.00 \mathrm{E}+00$ & $0.00 \mathrm{E}+00$ & $0.00 \mathrm{E}+00$ & $.00 \mathrm{E}+00$ & $0.00 \mathrm{E}+00$ & $6.99 \mathrm{E}-02$ & $0.00 \mathrm{E}+00$ \\
\hline $4.00 \mathrm{E}+02$ & $1.65 \mathrm{E}+00$ & $0.00 \mathrm{E}+00$ & $0.00 \mathrm{E}+00$ & $0.00 \mathrm{E}+00$ & $0.00 \mathrm{E}+00$ & $0.00 \mathrm{E}+00$ & $0.00 \mathrm{E}+00$ & $0.00 \mathrm{E}+00$ & $6.54 \mathrm{E}-02$ & $0.00 \mathrm{E}+00$ \\
\hline $4.10 \mathrm{E}+02$ & $1.64 \mathrm{E}+00$ & $0.00 \mathrm{E}+00$ & $0.00 \mathrm{E}+00$ & $0.00 \mathrm{E}+00$ & $0.00 \mathrm{E}+00$ & $0.00 \mathrm{E}+00$ & $0.00 \mathrm{E}+00$ & $0.00 \mathrm{E}+00$ & $6.12 \mathrm{E}-02$ & $0.00 \mathrm{E}+00$ \\
\hline $4.20 \mathrm{E}+02$ & $1.63 E+00$ & $0.00 \mathrm{E}+00$ & $0.00 \mathrm{E}+00$ & $0.00 \mathrm{E}+00$ & $0.00 \mathrm{E}+00$ & $0.00 \mathrm{E}+00$ & $0.00 \mathrm{E}+00$ & $0.00 \mathrm{E}+00$ & $5.72 \mathrm{E}-02$ & $0.00 \mathrm{E}+00$ \\
\hline $4.30 \mathrm{E}+02$ & $1.62 \mathrm{E}+00$ & $0.00 \mathrm{E}+00$ & $0.00 \mathrm{E}+00$ & $0.00 \mathrm{E}+00$ & $0.00 \mathrm{E}+00$ & $0.00 \mathrm{E}+00$ & $0.00 \mathrm{E}+00$ & $0.00 \mathrm{E}+00$ & $5.86 \mathrm{E}-02$ & $0.00 \mathrm{E}+00$ \\
\hline $4.40 \mathrm{E}+02$ & $1.61 \mathrm{E}+00$ & $0.00 \mathrm{E}+00$ & $0.00 \mathrm{E}+00$ & $0.00 \mathrm{E}+00$ & $0.00 \mathrm{E}+00$ & $0.00 \mathrm{E}+00$ & $0.00 \mathrm{E}+00$ & $0.00 \mathrm{E}+00$ & $6.24 \mathrm{E}-02$ & $0.00 \mathrm{E}+00$ \\
\hline $4.50 \mathrm{E}+02$ & $1.59 \mathrm{E}+00$ & $0.00 \mathrm{E}+00$ & $0.00 \mathrm{E}+00$ & $0.00 \mathrm{E}+00$ & $0.00 \mathrm{E}+00$ & $0.00 \mathrm{E}+00$ & $0.00 \mathrm{E}+00$ & $0.00 \mathrm{E}+00$ & $6.63 \mathrm{E}-02$ & $.00 \mathrm{E}+00$ \\
\hline $4.60 \mathrm{E}+02$ & $1.58 \mathrm{E}+00$ & $0.00 \mathrm{E}+00$ & $0.00 \mathrm{E}+00$ & $0.00 \mathrm{E}+00$ & $0.00 \mathrm{E}+00$ & $0.00 \mathrm{E}+00$ & $0.00 \mathrm{E}+00$ & $0.00 \mathrm{E}+00$ & $7.00 \mathrm{E}-02$ & $0.00 \mathrm{E}+00$ \\
\hline $4.70 \mathrm{E}+02$ & $1.56 \mathrm{E}+00$ & $0.00 \mathrm{E}+00$ & $0.00 \mathrm{E}+00$ & $0.00 \mathrm{E}+00$ & $0.00 \mathrm{E}+00$ & $0.00 \mathrm{E}+00$ & $0.00 \mathrm{E}+00$ & $0.00 \mathrm{E}+00$ & $7.37 \mathrm{E}-02$ & $0.00 \mathrm{E}+00$ \\
\hline $4.80 \mathrm{E}+02$ & $1.55 \mathrm{E}+00$ & $0.00 \mathrm{E}+00$ & $0.00 \mathrm{E}+00$ & $0.00 \mathrm{E}+00$ & $0.00 \mathrm{E}+00$ & $0.00 \mathrm{E}+00$ & $0.00 \mathrm{E}+00$ & $0.00 \mathrm{E}+00$ & $7.73 \mathrm{E}-02$ & $0.00 \mathrm{E}+00$ \\
\hline $4.90 \mathrm{E}+02$ & $1.53 E+00$ & $0.00 \mathrm{E}+00$ & $0.00 \mathrm{E}+00$ & $0.00 \mathrm{E}+00$ & $0.00 \mathrm{E}+00$ & $0.00 \mathrm{E}+00$ & $0.00 \mathrm{E}+00$ & $0.00 \mathrm{E}+00$ & $7.76 \mathrm{E}-02$ & $0.00 \mathrm{E}+00$ \\
\hline $5.00 \mathrm{E}+02$ & $1.52 \mathrm{E}+00$ & $0.00 \mathrm{E}+00$ & $0.00 \mathrm{E}+00$ & $0.00 \mathrm{E}+00$ & $0.00 \mathrm{E}+00$ & $0.00 \mathrm{E}+00$ & $0.00 \mathrm{E}+00$ & $0.00 \mathrm{E}+00$ & $7.58 \mathrm{E}-02$ & $0.00 \mathrm{E}+00$ \\
\hline $5.10 \mathrm{E}+02$ & $1.50 \mathrm{E}+00$ & $0.00 \mathrm{E}+00$ & $0.00 \mathrm{E}+00$ & $0.00 \mathrm{E}+00$ & $0.00 \mathrm{E}+00$ & $0.00 \mathrm{E}+00$ & $0.00 \mathrm{E}+00$ & $0.00 \mathrm{E}+00$ & $7.38 \mathrm{E}-02$ & $0.00 \mathrm{E}+00$ \\
\hline $5.20 \mathrm{E}+02$ & $1.48 \mathrm{E}+00$ & $0.00 \mathrm{E}+00$ & $0.00 \mathrm{E}+00$ & $0.00 \mathrm{E}+00$ & $0.00 \mathrm{E}+00$ & $0.00 \mathrm{E}+00$ & $0.00 \mathrm{E}+00$ & $0.00 \mathrm{E}+00$ & $7.19 \mathrm{E}-02$ & $0.00 \mathrm{E}+00$ \\
\hline $5.30 \mathrm{E}+02$ & $1.47 \mathrm{E}+00$ & $0.00 \mathrm{E}+00$ & $0.00 \mathrm{E}+00$ & $0.00 \mathrm{E}+00$ & $0.00 \mathrm{E}+00$ & $0.00 \mathrm{E}+00$ & $0.00 \mathrm{E}+00$ & $0.00 \mathrm{E}+00$ & $7.01 \mathrm{E}-02$ & $0.00 \mathrm{E}+00$ \\
\hline $5.40 \mathrm{E}+02$ & $1.46 \mathrm{E}+00$ & $0.00 \mathrm{E}+00$ & $0.00 \mathrm{E}+00$ & $0.00 \mathrm{E}+00$ & $0.00 \mathrm{E}+00$ & $0.00 \mathrm{E}+00$ & $0.00 \mathrm{E}+00$ & $0.00 \mathrm{E}+00$ & $6.84 \mathrm{E}-02$ & $0.00 \mathrm{E}+00$ \\
\hline $5.50 \mathrm{E}+02$ & $1.44 \mathrm{E}+00$ & $0.00 \mathrm{E}+00$ & $0.00 \mathrm{E}+00$ & $0.00 \mathrm{E}+00$ & $0.00 \mathrm{E}+00$ & $0.00 \mathrm{E}+00$ & $0.00 \mathrm{E}+00$ & $0.00 \mathrm{E}+00$ & 5.94E-02 & $0.00 \mathrm{E}+00$ \\
\hline $5.60 \mathrm{E}+02$ & $1.43 \mathrm{E}+00$ & $0.00 \mathrm{E}+00$ & $0.00 \mathrm{E}+00$ & $0.00 \mathrm{E}+00$ & $0.00 \mathrm{E}+00$ & $0.00 \mathrm{E}+00$ & $0.00 \mathrm{E}+00$ & $0.00 \mathrm{E}+00$ & $4.60 \mathrm{E}-02$ & $0.00 \mathrm{E}+00$ \\
\hline $5.70 \mathrm{E}+02$ & $1.42 \mathrm{E}+00$ & $0.00 \mathrm{E}+00$ & $0.00 \mathrm{E}+00$ & $0.00 \mathrm{E}+00$ & $0.00 \mathrm{E}+00$ & $0.00 \mathrm{E}+00$ & $0.00 \mathrm{E}+00$ & $0.00 \mathrm{E}+00$ & $3.26 \mathrm{E}-02$ & $0.00 \mathrm{E}+00$ \\
\hline $5.80 \mathrm{E}+02$ & $1.42 \mathrm{E}+00$ & $0.00 \mathrm{E}+00$ & $0.00 \mathrm{E}+00$ & $0.00 \mathrm{E}+00$ & $0.00 \mathrm{E}+00$ & $0.00 \mathrm{E}+00$ & $0.00 \mathrm{E}+00$ & $0.00 \mathrm{E}+00$ & $1.99 \mathrm{E}-02$ & $0.00 \mathrm{E}+00$ \\
\hline $5.90 \mathrm{E}+02$ & $1.41 \mathrm{E}+00$ & $0.00 \mathrm{E}+00$ & $0.00 \mathrm{E}+00$ & $0.00 \mathrm{E}+00$ & $0.00 \mathrm{E}+00$ & $0.00 \mathrm{E}+00$ & $0.00 \mathrm{E}+00$ & $0.00 \mathrm{E}+00$ & $7.63 \mathrm{E}-03$ & $0.00 \mathrm{E}+00$ \\
\hline
\end{tabular}




\section{Heat Release Rate}

Part I- Base Case

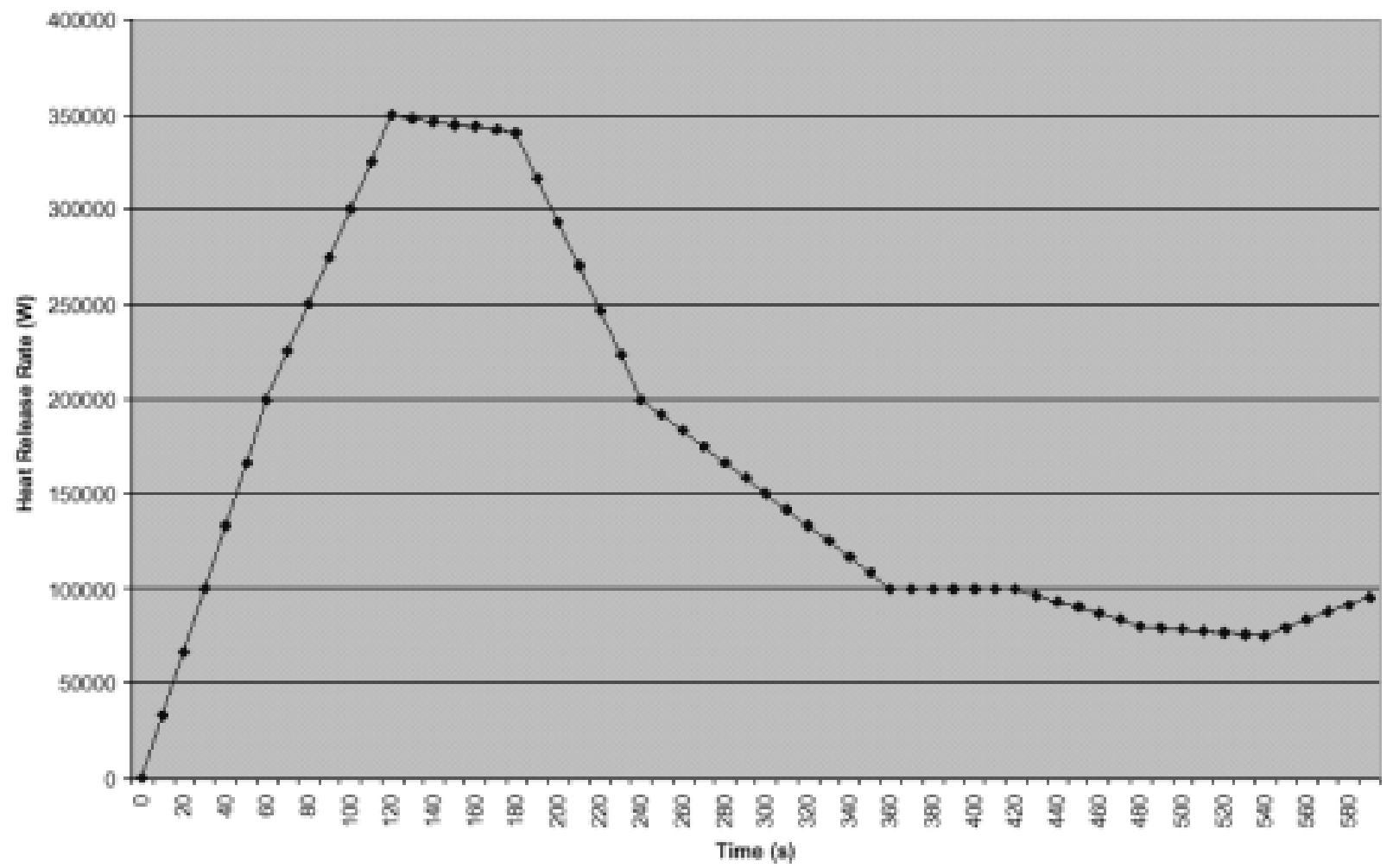

Oxygen Concentration

Part I - Base Case

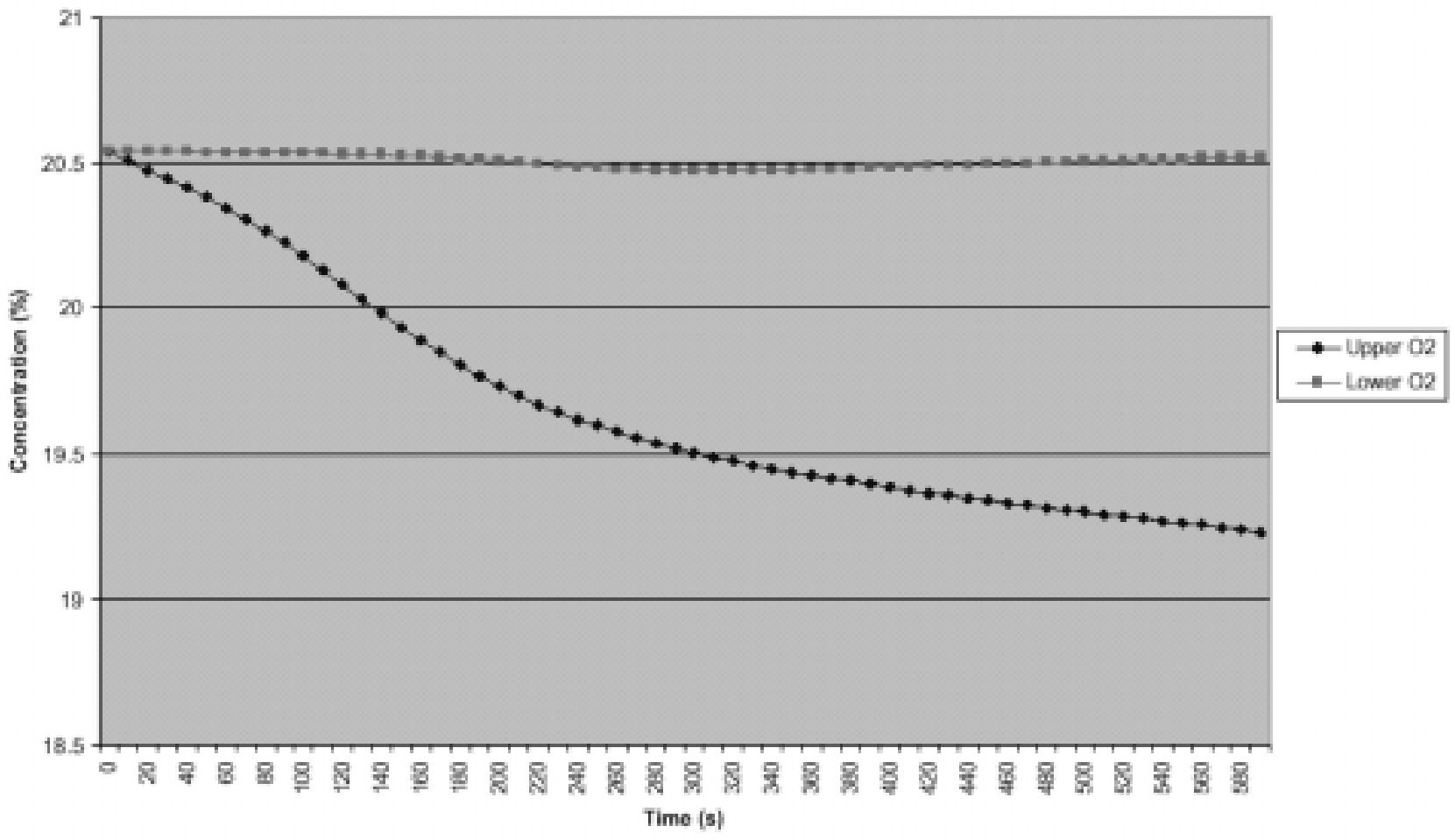


Plume Flow

Part I-Base Case

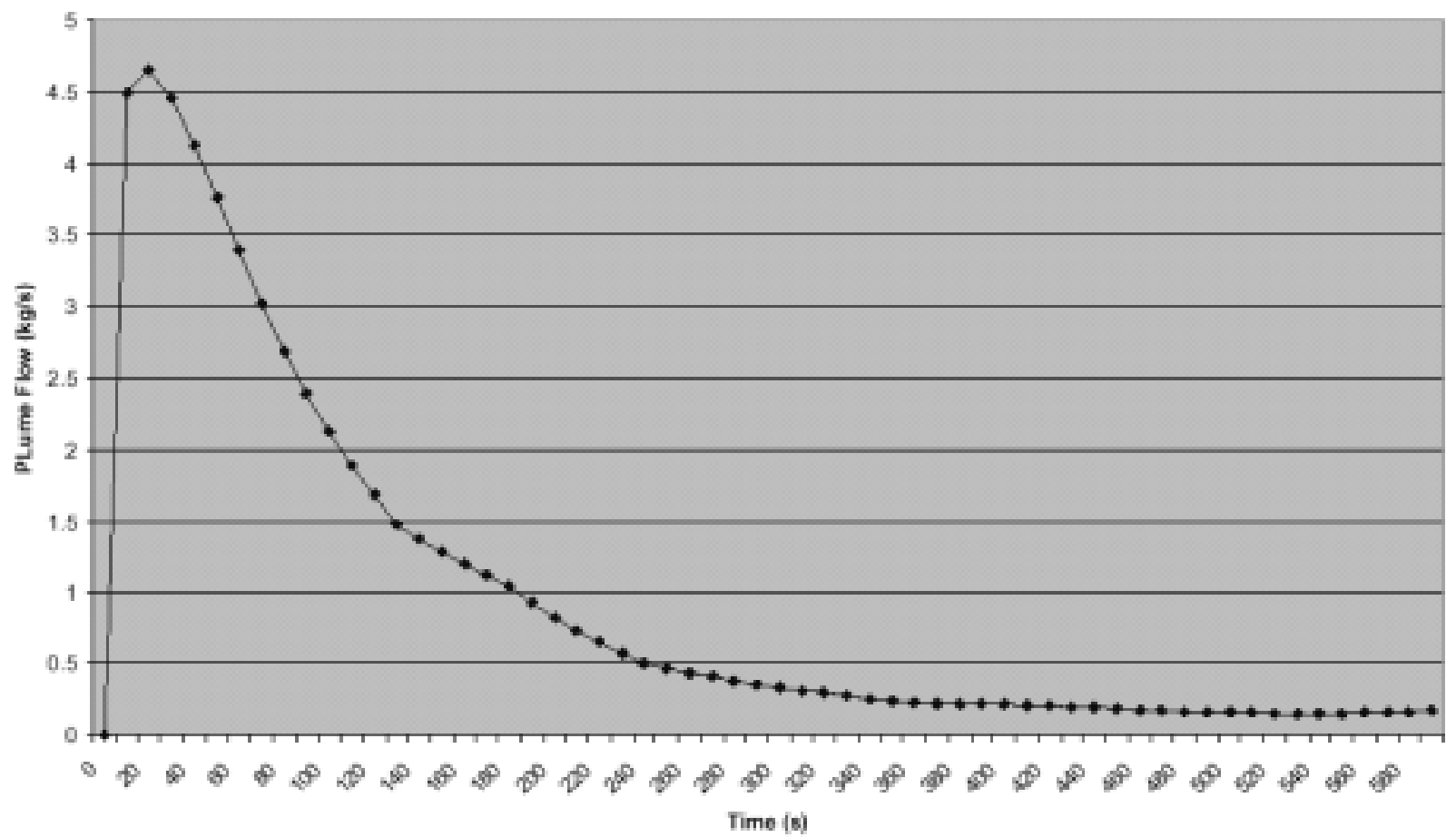

Pressure

Part I- Base Case

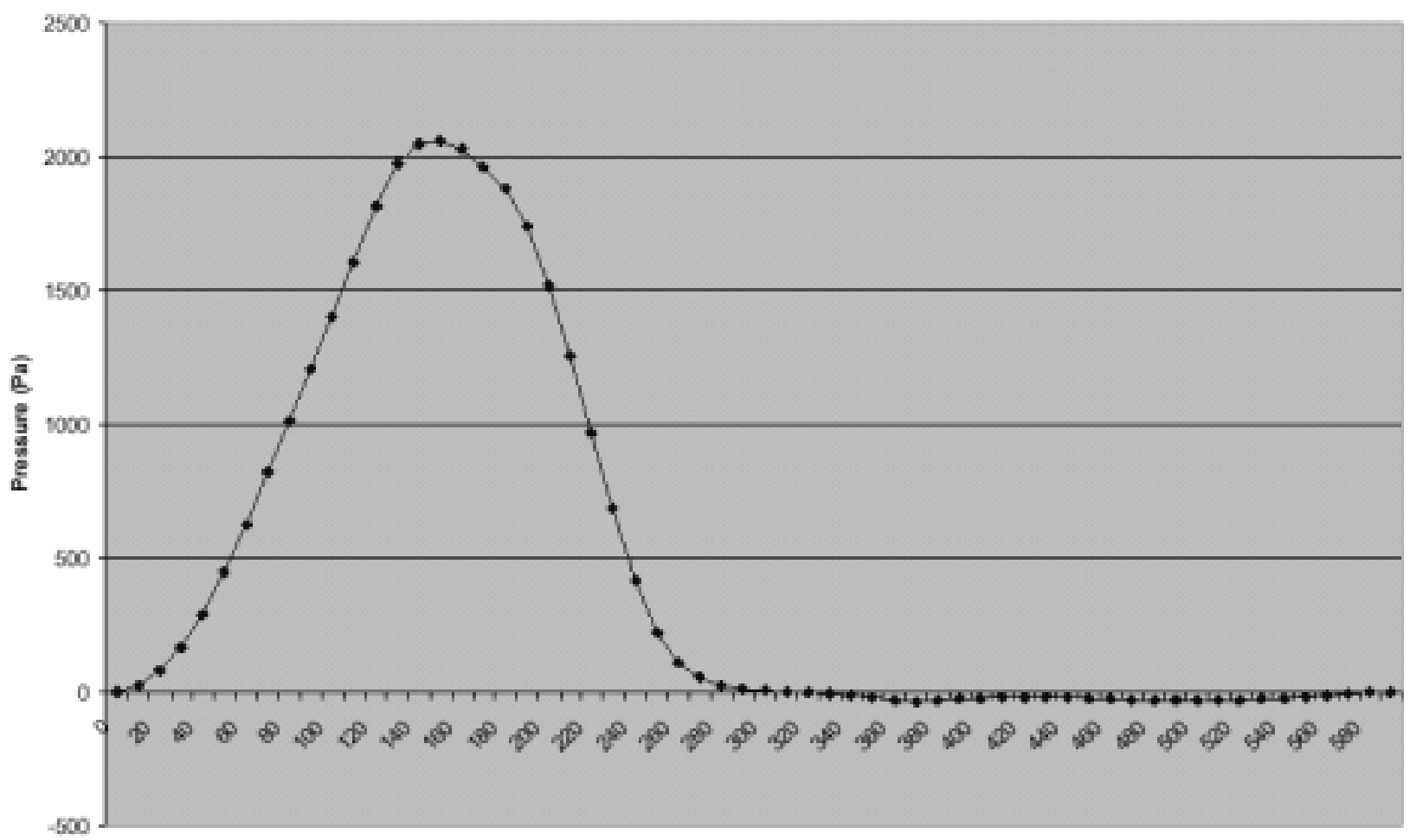

Tims (s) 


\section{Lower Layer Outflow}

Part I-Base Case

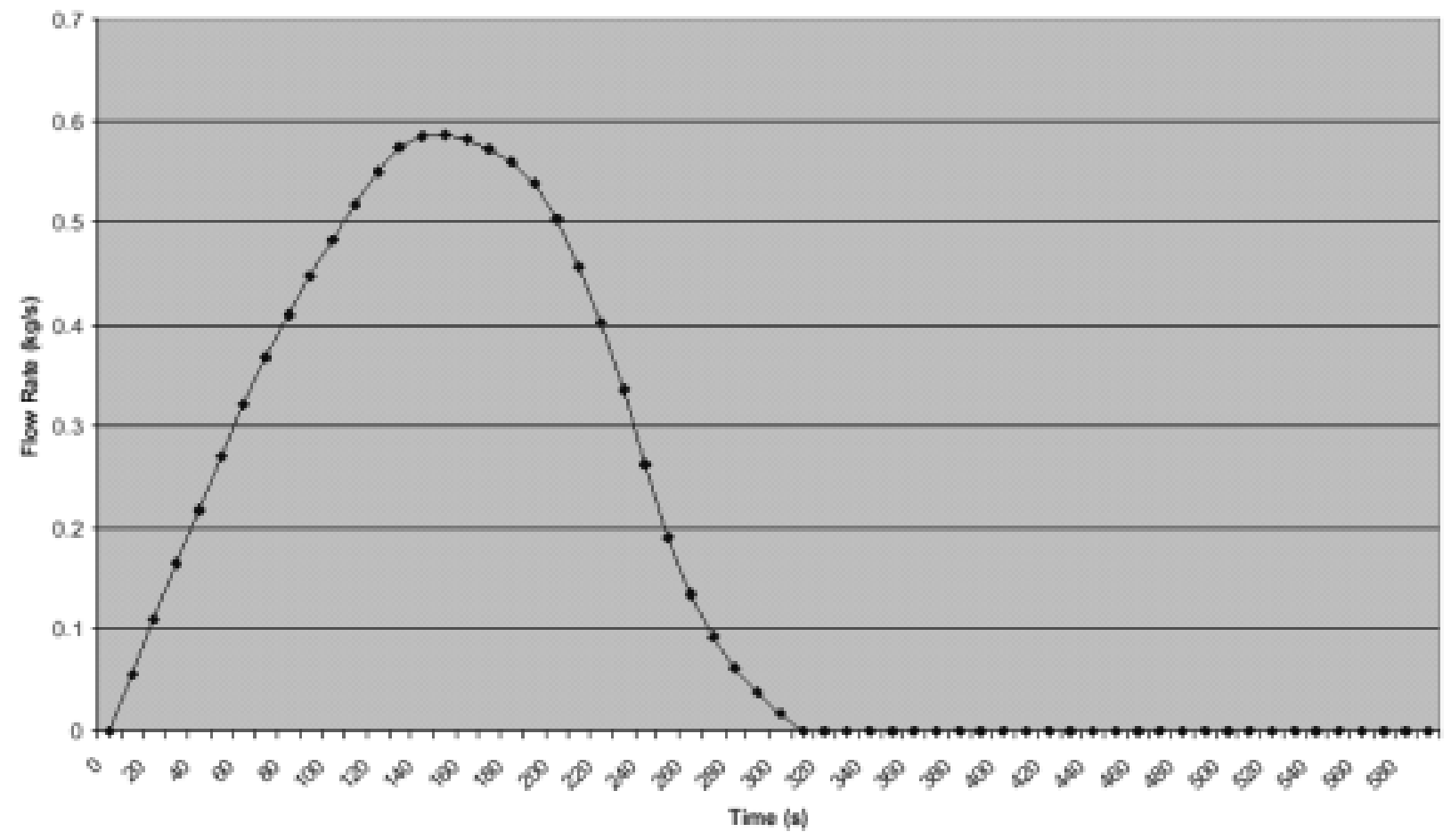

\section{Lower Layer Inflow}

Part I - Base Case

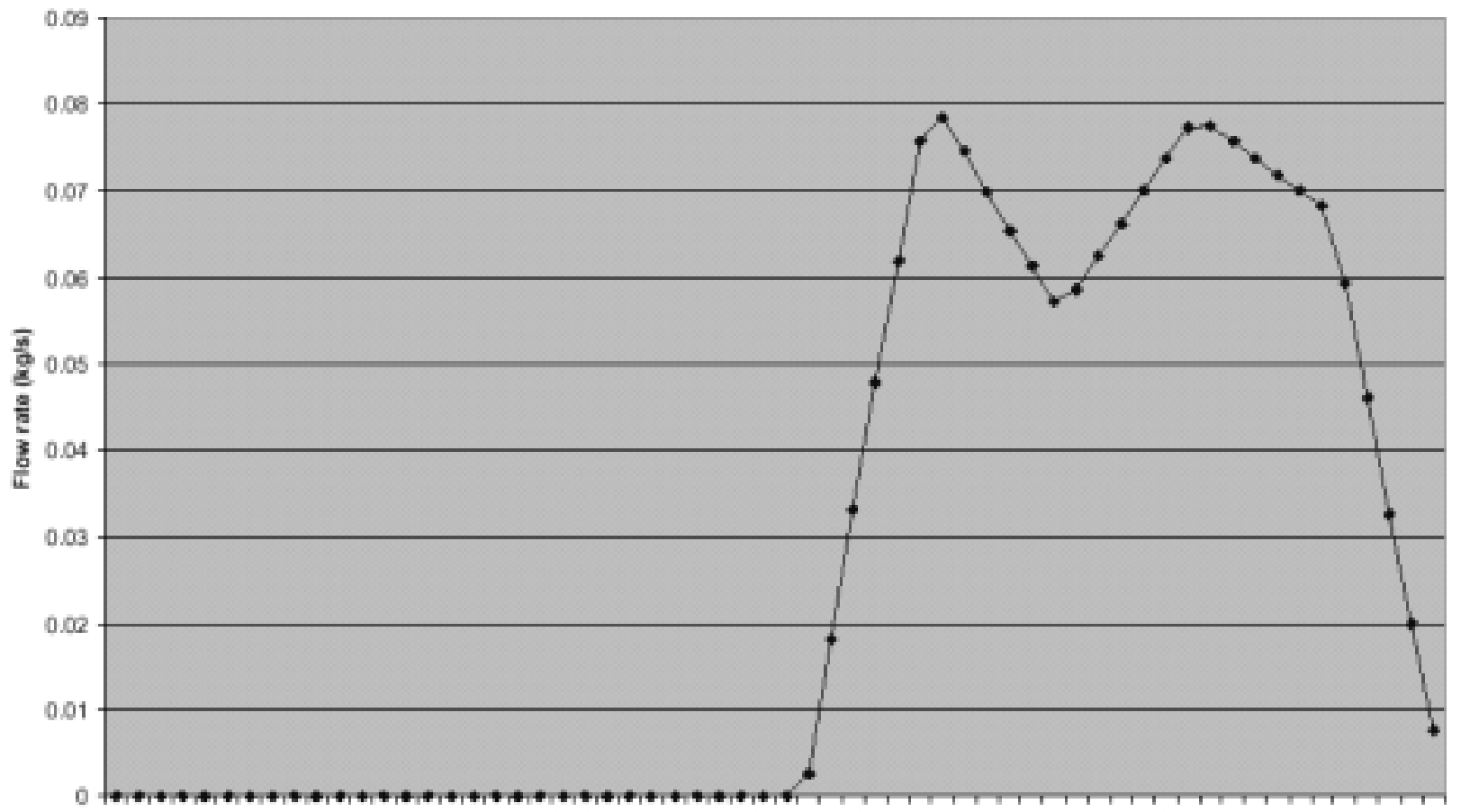

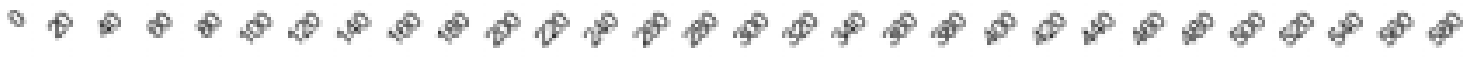
Time (s) 
Layer Height

Part I-Base Case

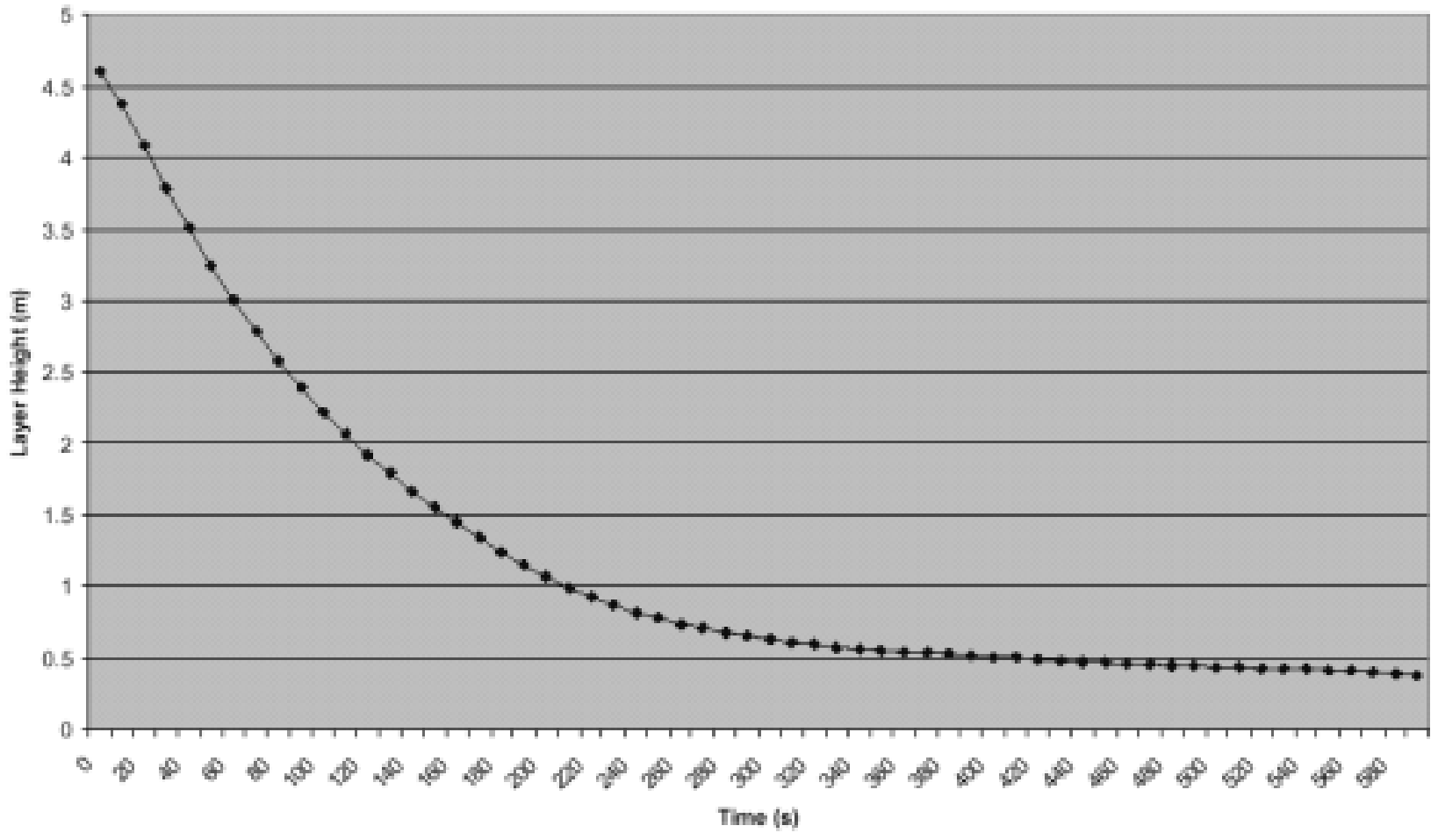

Upper Layer Temperature

Part I-Base Case

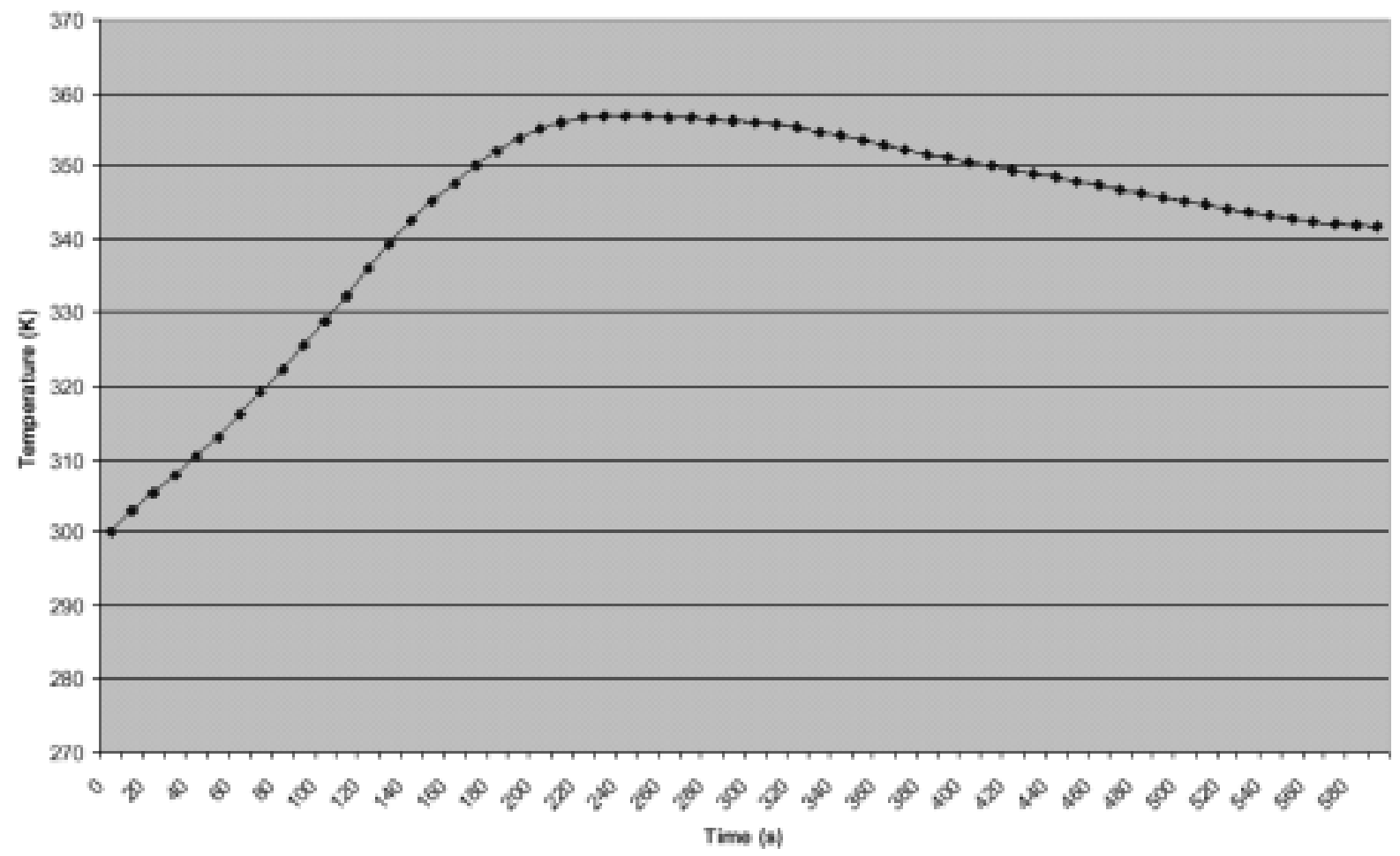




\section{Incident Flux on Target}

Part I - Base Case

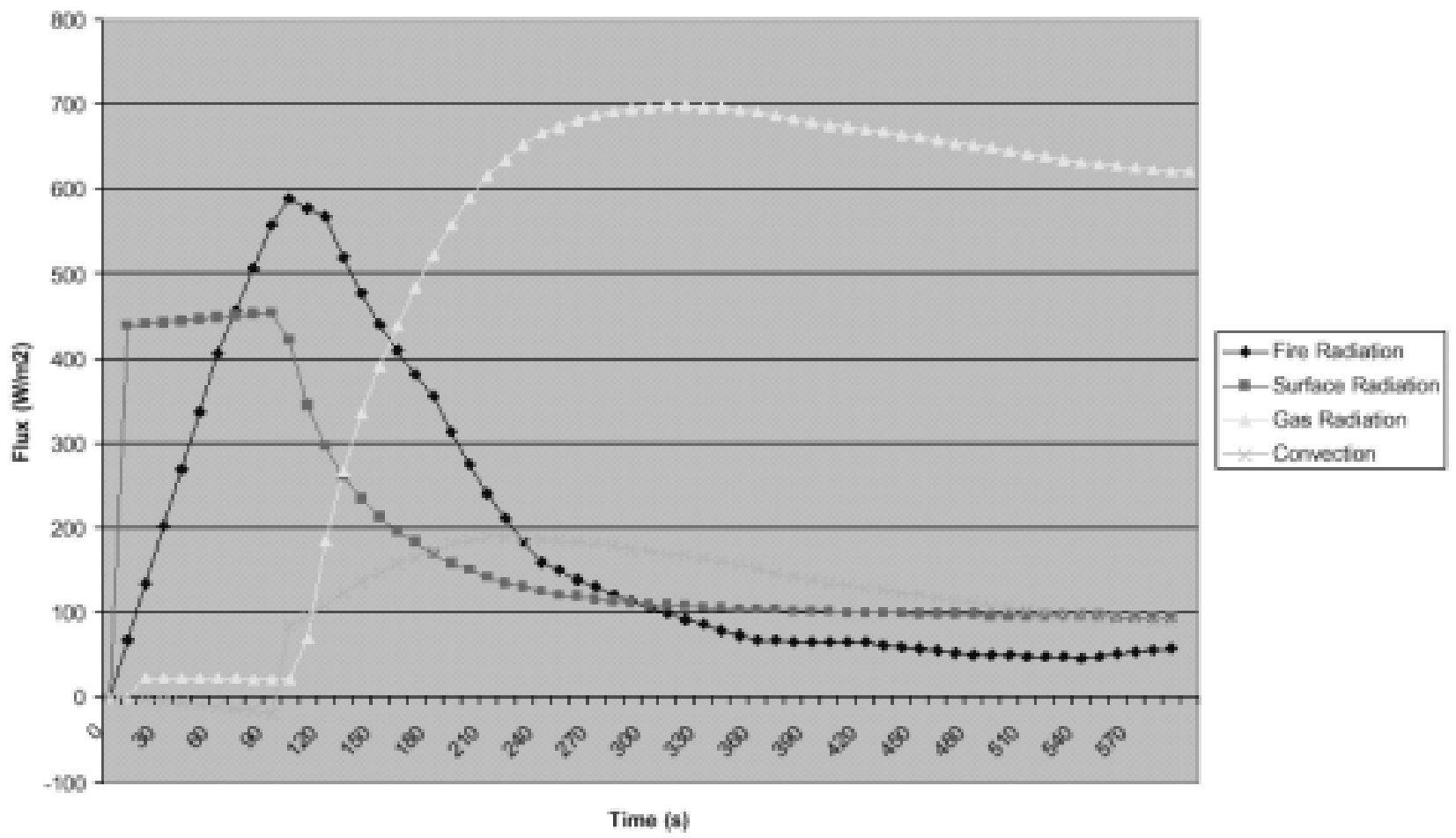

\section{Target Surface Temperature}

Part I Base Case

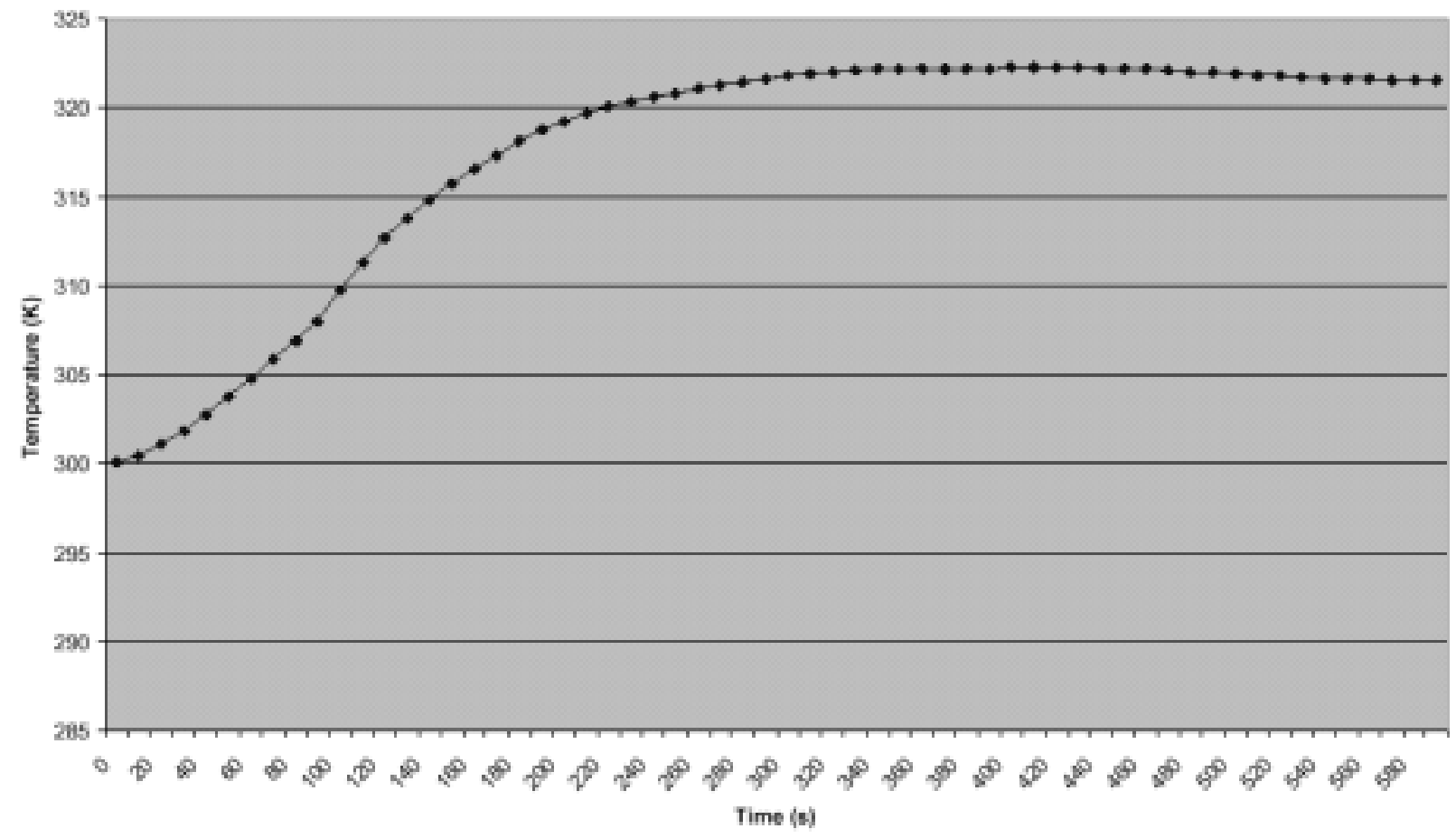


WSRC-TR-2001-00405

Appendix 5 - Results from Verification Effort 
WSRC-TR-2001-00405

\begin{tabular}{|c|c|c|c|c|c|c|c|c|c|c|c|}
\hline TIME & \begin{tabular}{|c|} 
Upper Layer \\
Temp (1) \\
\end{tabular} & $\begin{array}{c}\text { Lower Layer } \\
\text { Temp (1) }\end{array}$ & $\begin{array}{c}\text { Layer Height } \\
\text { (1) }\end{array}$ & $\begin{array}{l}\text { Upper Layer } \\
\text { Volume (1) }\end{array}$ & Pressure (1) & $\begin{array}{c}\text { Ambient } \\
\text { Target (1) }\end{array}$ & $\begin{array}{c}\text { Floor Target } \\
\text { (1) }\end{array}$ & $\begin{array}{c}\text { Main Plume } \\
\text { Flow }\end{array}$ & $\begin{array}{c}\text { Main } \\
\text { Pyrolysis } \\
\text { Rate }\end{array}$ & $\begin{array}{c}\text { Main Fire } \\
\text { Size }\end{array}$ & $\begin{array}{c}\text { Main Flame } \\
\text { Height }\end{array}$ \\
\hline $0.00 \mathrm{E}+00$ & $3.00 \mathrm{E}+02$ & $3.00 \mathrm{E}+02$ & $4.60 \mathrm{E}+00$ & $6.36 \mathrm{E}-02$ & $-1.48 \mathrm{E}-18$ & $0.00 \mathrm{E}+00$ & $0.00 \mathrm{E}+00$ & $0.00 \mathrm{E}+00$ & $0.00 \mathrm{E}+00$ & $0.00 \mathrm{E}+00$ & $0.00 \mathrm{E}+00$ \\
\hline $1.00 \mathrm{E}+01$ & $3.03 E+02$ & $3.00 \mathrm{E}+02$ & $4.37 \mathrm{E}+00$ & $3.18 \mathrm{E}+01$ & $1.85 \mathrm{E}+01$ & $2.10 \mathrm{E}+00$ & $1.72 \mathrm{E}+00$ & $4.48 \mathrm{E}+00$ & $1.38 \mathrm{E}-03$ & $3.33 \mathrm{E}+04$ & $6.04 \mathrm{E}-01$ \\
\hline $2.00 \mathrm{E}+01$ & $.05 \mathrm{E}+02$ & $3.00 \mathrm{E}+02$ & $4.08 \mathrm{E}+00$ & $7.23 E+01$ & $7.41 \mathrm{E}+01$ & $5.57 \mathrm{E}+00$ & $4.50 \mathrm{E}+00$ & $4.65 \mathrm{E}+00$ & $2.77 \mathrm{E}-03$ & $6.67 \mathrm{E}+04$ & $8.95 \mathrm{E}-01$ \\
\hline $3.00 \mathrm{E}+01$ & $.08 \mathrm{E}+02$ & $3.00 \mathrm{E}+02$ & $78 \mathrm{E}+00$ & $1.13 \mathrm{E}+02$ & $1.65 \mathrm{E}+02$ & $1.04 \mathrm{E}+01$ & $48 \mathrm{E}+00$ & $4.45 \mathrm{E}+00$ & $.15 \mathrm{E}-03$ & $1.00 \mathrm{E}+05$ & $1.11 \mathrm{E}+00$ \\
\hline $4.00 \mathrm{E}+01$ & $10 \mathrm{E}+02$ & $3.00 \mathrm{E}+02$ & $50 \mathrm{E}+00$ & $1.52 \mathrm{E}+02$ & $2.88 \mathrm{E}+02$ & $.68 \mathrm{E}+01$ & $1.38 \mathrm{E}+01$ & $13 \mathrm{E}+00$ & $.53 \mathrm{E}-03$ & $1.33 \mathrm{E}+05$ & $1.28 \mathrm{E}+00$ \\
\hline $5.00 \mathrm{E}+01$ & $3.13 E+02$ & $3.00 \mathrm{E}+02$ & $24 \mathrm{E}+00$ & $1.88 \mathrm{E}+02$ & $4.42 \mathrm{E}+02$ & $2.47 \mathrm{E}+01$ & $2.06 \mathrm{E}+01$ & $76 \mathrm{E}+00$ & $.92 \mathrm{E}-03$ & $1.67 \mathrm{E}+05$ & $1.42 \mathrm{E}+00$ \\
\hline $6.00 \mathrm{E}+01$ & $3.16 \mathrm{E}+02$ & $3.01 \mathrm{E}+02$ & $3.00 \mathrm{E}+00$ & $2.21 \mathrm{E}+02$ & $6.25 \mathrm{E}+02$ & $3.43 \mathrm{E}+01$ & $2.89 \mathrm{E}+01$ & $3.39 E+00$ & $8.30 \mathrm{E}-03$ & $2.00 \mathrm{E}+05$ & $1.55 \mathrm{E}+00$ \\
\hline $7.00 \mathrm{E}+01$ & $3.19 \mathrm{E}+02$ & $3.01 \mathrm{E}+02$ & $2.78 \mathrm{E}+00$ & $2.52 \mathrm{E}+02$ & $8.17 \mathrm{E}+02$ & $4.51 \mathrm{E}+01$ & $3.84 \mathrm{E}+01$ & $3.02 \mathrm{E}+00$ & $9.34 \mathrm{E}-03$ & $2.25 E+05$ & $1.64 \mathrm{E}+00$ \\
\hline $8.00 \mathrm{E}+01$ & $3.22 \mathrm{E}+02$ & $3.01 \mathrm{E}+02$ & $2.58 \mathrm{E}+00$ & $2.80 \mathrm{E}+02$ & $1.01 \mathrm{E}+03$ & $5.72 \mathrm{E}+01$ & $4.93 \mathrm{E}+01$ & $2.68 \mathrm{E}+00$ & 1.04E-02 & $2.50 \mathrm{E}+05$ & $1.72 \mathrm{E}+00$ \\
\hline $9.00 \mathrm{E}+01$ & $3.25 \mathrm{E}+02$ & $3.01 \mathrm{E}+02$ & $2.39 \mathrm{E}+00$ & $3.05 \mathrm{E}+02$ & $1.20 \mathrm{E}+03$ & $7.08 \mathrm{E}+01$ & $6.15 \mathrm{E}+01$ & $2.39 E+00$ & $1.14 \mathrm{E}-02$ & $2.75 \mathrm{E}+05$ & $1.80 \mathrm{E}+00$ \\
\hline $1.00 \mathrm{E}+02$ & $3.29 \mathrm{E}+02$ & $3.01 \mathrm{E}+02$ & $2.22 \mathrm{E}+00$ & $3.29 \mathrm{E}+02$ & $1.40 \mathrm{E}+03$ & $8.58 \mathrm{E}+01$ & $7.52 \mathrm{E}+01$ & $2.12 \mathrm{E}+00$ & $1.24 \mathrm{E}-02$ & $3.00 \mathrm{E}+05$ & $1.87 \mathrm{E}+00$ \\
\hline $1.10 \mathrm{E}+02$ & $3.32 \mathrm{E}+02$ & $3.01 \mathrm{E}+02$ & $2.07 \mathrm{E}+00$ & $3.50 \mathrm{E}+02$ & $1.61 \mathrm{E}+03$ & $1.02 \mathrm{E}+02$ & $9.05 \mathrm{E}+01$ & $1.88 \mathrm{E}+00$ & $1.35 \mathrm{E}-02$ & $3.25 \mathrm{E}+05$ & $1.94 \mathrm{E}+00$ \\
\hline $1.20 \mathrm{E}+02$ & $3.36 \mathrm{E}+02$ & $3.02 \mathrm{E}+02$ & $1.92 \mathrm{E}+00$ & & & & & & & 05 & $E+00$ \\
\hline $1.30 \mathrm{E}+02$ & $3.39 \mathrm{E}+02$ & $3.02 \mathrm{E}+02$ & $1.79 \mathrm{E}+00$ & $3.88 \mathrm{E}+02$ & +03 & $1.39 \mathrm{E}+02$ & +02 & $E+00$ & $5 \mathrm{E}-02$ & $3.48 \mathrm{E}+05$ & $2.00 \mathrm{E}+00$ \\
\hline $1.40 \mathrm{E}+02$ & $3.42 \mathrm{E}+02$ & $3.02 \mathrm{E}+02$ & $1.67 \mathrm{E}+00$ & $4.05 \mathrm{E}+02$ & $05 \mathrm{E}+03$ & $1.56 \mathrm{E}+02$ & $1.41 \mathrm{E}+02$ & $37 \mathrm{E}+00$ & 1.44E-02 & $3.47 \mathrm{E}+05$ & $2.00 \mathrm{E}+00$ \\
\hline $1.50 \mathrm{E}+02$ & $3.45 \mathrm{E}+02$ & $3.02 \mathrm{E}+02$ & $1.56 \mathrm{E}+00$ & $4.21 \mathrm{E}+02$ & $.06 \mathrm{E}+03$ & $1.73 \mathrm{E}+02$ & $1.57 \mathrm{E}+02$ & $1.28 \mathrm{E}+00$ & 1.43E-02 & $3.45 \mathrm{E}+05$ & $1.99 \mathrm{E}+00$ \\
\hline $1.60 \mathrm{E}+02$ & $3.48 \mathrm{E}+02$ & $3.02 \mathrm{E}+02$ & $1.45 \mathrm{E}+00$ & $4.36 \mathrm{E}+02$ & $2.03 \mathrm{E}+03$ & $1.90 \mathrm{E}+02$ & $1.73 E+02$ & $1.20 \mathrm{E}+00$ & $1.42 \mathrm{E}-02$ & $3.43 \mathrm{E}+05$ & $1.99 \mathrm{E}+00$ \\
\hline $1.70 \mathrm{E}+02$ & $3.50 \mathrm{E}+02$ & $3.02 \mathrm{E}+02$ & $1.34 \mathrm{E}+00$ & $4.51 \mathrm{E}+02$ & $1.96 \mathrm{E}+03$ & $2.06 \mathrm{E}+02$ & $1.88 \mathrm{E}+02$ & $1.11 \mathrm{E}+00$ & $1.42 \mathrm{E}-02$ & $3.42 \mathrm{E}+05$ & $1.99 \mathrm{E}+00$ \\
\hline $1.80 \mathrm{E}+02$ & $3.52 \mathrm{E}+02$ & $3.02 \mathrm{E}+02$ & $1.24 \mathrm{E}+00$ & $4.64 \mathrm{E}+02$ & $1.88 \mathrm{E}+03$ & $2.22 \mathrm{E}+02$ & $2.03 E+02$ & $1.04 \mathrm{E}+00$ & $1.41 \mathrm{E}-02$ & $3.40 \mathrm{E}+05$ & $1.98 \mathrm{E}+00$ \\
\hline $1.90 \mathrm{E}+02$ & $3.54 \mathrm{E}+02$ & $3.02 \mathrm{E}+02$ & $1.15 \mathrm{E}+00$ & $4.77 \mathrm{E}+02$ & $1.74 \mathrm{E}+03$ & $2.35 \mathrm{E}+02$ & $2.17 \mathrm{E}+02$ & 9.24E-01 & $1.31 \mathrm{E}-02$ & $3.17 \mathrm{E}+05$ & $1.92 \mathrm{E}+00$ \\
\hline $2.00 \mathrm{E}+02$ & $3.55 \mathrm{E}+02$ & $3.02 \mathrm{E}+02$ & $1.07 \mathrm{E}+00$ & $4.89 \mathrm{E}+02$ & $1.52 \mathrm{E}+03$ & $2.46 \mathrm{E}+02$ & $2.28 \mathrm{E}+02$ & $8.23 \mathrm{E}-01$ & $1.22 \mathrm{E}-02$ & $2.93 E+05$ & $1.85 \mathrm{E}+00$ \\
\hline $2.10 \mathrm{E}+02$ & $3.56 \mathrm{E}+02$ & $3.01 \mathrm{E}+02$ & $9.94 \mathrm{E}-01$ & $4.99 \mathrm{E}+02$ & $1.25 \mathrm{E}+03$ & $2.55 \mathrm{E}+02$ & $2.36 \mathrm{E}+02$ & $31 \mathrm{E}-01$ & $1.12 \mathrm{E}-02$ & $2.70 \mathrm{E}+05$ & $1.79 \mathrm{E}+00$ \\
\hline $2.20 \mathrm{E}+02$ & $3.57 \mathrm{E}+02$ & $3.01 \mathrm{E}+02$ & $9.28 \mathrm{E}-01$ & $5.08 \mathrm{E}+02$ & $9.68 \mathrm{E}+02$ & $2.62 \mathrm{E}+02$ & $2.43 \mathrm{E}+02$ & $48 \mathrm{E}-01$ & $1.02 \mathrm{E}-02$ & $2.47 \mathrm{E}+05$ & $1.71 \mathrm{E}+00$ \\
\hline $2.30 \mathrm{E}+02$ & $3.57 \mathrm{E}+02$ & $3.01 \mathrm{E}+02$ & $70 \mathrm{E}-01$ & $\mathrm{E}+02$ & $6.82 \mathrm{E}+02$ & $2.66 \mathrm{E}+02$ & $E+02$ & E-01 & $\mathrm{E}-03$ & $2.23 E+05$ & $E+00$ \\
\hline $2.40 \mathrm{E}+02$ & $3.57 \mathrm{E}+02$ & $3.01 \mathrm{E}+02$ & $\mathrm{E}-01$ & $\mathrm{E}+02$ & $E+02$ & $2.69 \mathrm{E}+02$ & $2.50 \mathrm{E}+02$ & E-01 & E-03 & $2.00 \mathrm{E}+05$ & $E+00$ \\
\hline $2.50 \mathrm{E}+02$ & $3.57 \mathrm{E}+02$ & $3.01 \mathrm{E}+02$ & $78 \mathrm{E}-01$ & $5.29 \mathrm{E}+02$ & $2.21 \mathrm{E}+02$ & $2.71 \mathrm{E}+02$ & $2.52 \mathrm{E}+02$ & $4.70 \mathrm{E}-01$ & $7.95 \mathrm{E}-03$ & $1.92 \mathrm{E}+05$ & $1.53 E+00$ \\
\hline $2.60 \mathrm{E}+02$ & $3.57 \mathrm{E}+02$ & $3.01 \mathrm{E}+02$ & $7.41 \mathrm{E}-01$ & $5.34 \mathrm{E}+02$ & $1.09 \mathrm{E}+02$ & $2.72 \mathrm{E}+02$ & $2.54 \mathrm{E}+02$ & $4.38 \mathrm{E}-01$ & $7.61 \mathrm{E}-03$ & $1.83 E+05$ & $1.49 \mathrm{E}+00$ \\
\hline $2.70 \mathrm{E}+02$ & $3.57 \mathrm{E}+02$ & $3.01 \mathrm{E}+02$ & 7.09E-01 & $5.38 \mathrm{E}+02$ & $5.17 \mathrm{E}+01$ & $2.74 \mathrm{E}+02$ & $2.56 \mathrm{E}+02$ & $.08 \mathrm{E}-01$ & $7.26 \mathrm{E}-03$ & $1.75 \mathrm{E}+05$ & $1.46 \mathrm{E}+00$ \\
\hline $2.80 \mathrm{E}+02$ & $3.56 \mathrm{E}+02$ & $3.01 \mathrm{E}+02$ & $6.80 \mathrm{E}-01$ & $5.42 \mathrm{E}+02$ & $2.38 \mathrm{E}+01$ & $2.75 \mathrm{E}+02$ & $2.57 \mathrm{E}+02$ & $3.81 \mathrm{E}-01$ & $6.92 \mathrm{E}-03$ & $1.67 \mathrm{E}+05$ & $1.43 \mathrm{E}+00$ \\
\hline $2.90 \mathrm{E}+02$ & $3.56 \mathrm{E}+02$ & $3.01 \mathrm{E}+02$ & $6.55 \mathrm{E}-01$ & $5.46 \mathrm{E}+02$ & $9.16 \mathrm{E}+00$ & $2.75 \mathrm{E}+02$ & $2.57 \mathrm{E}+02$ & $3.56 \mathrm{E}-01$ & $6.57 \mathrm{E}-03$ & $1.58 \mathrm{E}+05$ & $1.39 \mathrm{E}+00$ \\
\hline $3.00 \mathrm{E}+02$ & $3.56 \mathrm{E}+02$ & $3.01 \mathrm{E}+02$ & 6.32E-01 & $5.49 \mathrm{E}+02$ & $1.81 \mathrm{E}+00$ & $2.75 \mathrm{E}+02$ & $2.57 \mathrm{E}+02$ & EE-01 & $22 \mathrm{E}-03$ & $1.50 \mathrm{E}+05$ & $1.36 \mathrm{E}+00$ \\
\hline $3.10 \mathrm{E}+02$ & $3.56 \mathrm{E}+02$ & $3.01 \mathrm{E}+02$ & $6.12 \mathrm{E}-01$ & $5.52 \mathrm{E}+02$ & $-3.83 \mathrm{E}-02$ & $2.74 \mathrm{E}+02$ & $2.57 \mathrm{E}+02$ & -01 & 03 & $1.42 \mathrm{E}+05$ & $1.32 \mathrm{E}+00$ \\
\hline $3.20 \mathrm{E}+02$ & $3.55 \mathrm{E}+02$ & $3.01 \mathrm{E}+02$ & $5.95 \mathrm{E}-01$ & $5.54 \mathrm{E}+02$ & $-1.99 \mathrm{E}+00$ & $2.73 \mathrm{E}+02$ & $.56 \mathrm{E}+02$ & 2.93E-01 & $.53 \mathrm{E}-03$ & $1.33 \mathrm{E}+05$ & $1.28 \mathrm{E}+00$ \\
\hline $3.30 \mathrm{E}+02$ & $3.55 \mathrm{E}+02$ & $3.01 \mathrm{E}+02$ & $\mathrm{E}-01$ & $5.56 \mathrm{E}+02$ & $-6.69 \mathrm{E}+00$ & $2.71 \mathrm{E}+02$ & $2.54 \mathrm{E}+02$ & $\mathrm{E}-01$ & $\mathrm{E}-03$ & $1.25 \mathrm{E}+05$ & $1.24 \mathrm{E}+00$ \\
\hline $3.40 \mathrm{E}+02$ & $3.54 \mathrm{E}+02$ & $3.01 \mathrm{E}+02$ & $6 \mathrm{E}-01$ & $5.58 \mathrm{E}+02$ & $-1.39 \mathrm{E}+01$ & $2.69 \mathrm{E}+02$ & $2.52 \mathrm{E}+02$ & $2.57 \mathrm{E}-01$ & $4.84 \mathrm{E}-03$ & $1.17 \mathrm{E}+05$ & $E+00$ \\
\hline $3.50 \mathrm{E}+02$ & $3.54 \mathrm{E}+02$ & $3.01 \mathrm{E}+02$ & $.54 \mathrm{E}-01$ & $5.60 \mathrm{E}+02$ & $-2.33 \mathrm{E}+01$ & $2.66 \mathrm{E}+02$ & $2.49 \mathrm{E}+02$ & $2.40 \mathrm{E}-01$ & $4.50 \mathrm{E}-03$ & $1.08 \mathrm{E}+05$ & $1.15 \mathrm{E}+00$ \\
\hline $3.60 \mathrm{E}+02$ & $3.53 \mathrm{E}+02$ & $3.01 \mathrm{E}+02$ & $5.44 \mathrm{E}-01$ & $5.61 \mathrm{E}+02$ & $-3.48 \mathrm{E}+01$ & $2.63 \mathrm{E}+02$ & $2.45 \mathrm{E}+02$ & 2.25E-01 & $4.15 \mathrm{E}-03$ & $1.00 \mathrm{E}+05$ & $1.11 \mathrm{E}+00$ \\
\hline $3.70 \mathrm{E}+02$ & $3.52 \mathrm{E}+02$ & $3.01 \mathrm{E}+02$ & 5.35E-01 & $5.62 \mathrm{E}+02$ & $-3.73 \mathrm{E}+01$ & $2.59 \mathrm{E}+02$ & $2.42 \mathrm{E}+02$ & $2.21 \mathrm{E}-01$ & 4.15E-03 & $1.00 \mathrm{E}+05$ & $1.11 \mathrm{E}+00$ \\
\hline $3.80 \mathrm{E}+02$ & $3.52 \mathrm{E}+02$ & $3.01 \mathrm{E}+02$ & $5.27 \mathrm{E}-01$ & $5.63 \mathrm{E}+02$ & $-3.37 \mathrm{E}+01$ & $2.56 \mathrm{E}+02$ & $2.39 \mathrm{E}+02$ & $2.18 \mathrm{E}-01$ & 4.15E-03 & $1.00 \mathrm{E}+05$ & $1.11 \mathrm{E}+00$ \\
\hline $3.90 \mathrm{E}+02$ & $3.51 \mathrm{E}+02$ & $3.01 \mathrm{E}+02$ & $5.18 \mathrm{E}-01$ & $5.65 \mathrm{E}+02$ & $-2.97 \mathrm{E}+01$ & $2.53 \mathrm{E}+02$ & $2.36 \mathrm{E}+02$ & $2.15 \mathrm{E}-01$ & $4.15 \mathrm{E}-03$ & $1.00 \mathrm{E}+05$ & $1.11 \mathrm{E}+00$ \\
\hline $4.00 \mathrm{E}+02$ & $3.51 \mathrm{E}+02$ & $3.01 \mathrm{E}+02$ & 09E-01 & $5.66 \mathrm{E}+02$ & $-2.60 \mathrm{E}+01$ & $2.51 \mathrm{E}+02$ & $2.33 E+02$ & $2 \mathrm{E}-01$ & & $1.00 \mathrm{E}+05$ & $1.11 \mathrm{E}+00$ \\
\hline $4.10 \mathrm{E}+02$ & $3.50 \mathrm{E}+02$ & $3.01 \mathrm{E}+02$ & $5.01 \mathrm{E}-01$ & $5.67 \mathrm{E}+02$ & $-2.28 \mathrm{E}+01$ & $2.48 \mathrm{E}+02$ & $2.31 \mathrm{E}+02$ & BE-01 & $\mathrm{E}-03$ & $E+05$ & $\mathrm{E}+00$ \\
\hline $4.20 \mathrm{E}+02$ & $3.49 \mathrm{E}+02$ & $3.01 \mathrm{E}+02$ & $4.92 \mathrm{E}-01$ & $5.68 \mathrm{E}+02$ & $-1.99 \mathrm{E}+01$ & $2.46 \mathrm{E}+02$ & $2.28 \mathrm{E}+02$ & $2.05 \mathrm{E}-01$ & $.15 \mathrm{E}-03$ & $1.00 \mathrm{E}+05$ & $1.11 \mathrm{E}+00$ \\
\hline $4.30 \mathrm{E}+02$ & $49 \mathrm{E}+02$ & $01 \mathrm{E}+02$ & $83 \mathrm{E}-01$ & $5.69 \mathrm{E}+02$ & $-2.09 \mathrm{E}+01$ & $2.43 \mathrm{E}+02$ & $2.26 \mathrm{E}+02$ & 1.97E-01 & $4.01 \mathrm{E}-03$ & $9.67 \mathrm{E}+04$ & $E+00$ \\
\hline $4.40 \mathrm{E}+02$ & $3.48 \mathrm{E}+02$ & $1 \mathrm{E}+02$ & $5 \mathrm{E}-01$ & $\mathrm{E}+02$ & $-2.37 \mathrm{E}+01$ & $2.41 \mathrm{E}+02$ & $2.23 E+02$ & $1.90 \mathrm{E}-01$ & $.87 \mathrm{E}-03$ & $9.33 \mathrm{E}+04$ & $1.07 \mathrm{E}+00$ \\
\hline $4.50 \mathrm{E}+02$ & $3.48 \mathrm{E}+02$ & $3.02 \mathrm{E}+02$ & $4.68 \mathrm{E}-01$ & $5.72 \mathrm{E}+02$ & $-2.67 \mathrm{E}+01$ & $2.38 \mathrm{E}+02$ & $2.21 \mathrm{E}+02$ & 1.83E-01 & $3.73 \mathrm{E}-03$ & $9.00 \mathrm{E}+04$ & $1.05 \mathrm{E}+00$ \\
\hline $4.60 \mathrm{E}+02$ & $3.47 \mathrm{E}+02$ & $3.02 \mathrm{E}+02$ & 4.61E-01 & $5.72 \mathrm{E}+02$ & $-2.98 \mathrm{E}+01$ & $2.35 \mathrm{E}+02$ & $2.18 \mathrm{E}+02$ & 1.76E-01 & $3.60 \mathrm{E}-03$ & $8.67 \mathrm{E}+04$ & $1.03 \mathrm{E}+00$ \\
\hline $4.70 \mathrm{E}+02$ & $3.47 \mathrm{E}+02$ & $3.02 \mathrm{E}+02$ & $4.55 \mathrm{E}-01$ & $5.73 \mathrm{E}+02$ & $-3.30 \mathrm{E}+01$ & $2.32 \mathrm{E}+02$ & $2.15 \mathrm{E}+02$ & $1.70 \mathrm{E}-01$ & $3.46 \mathrm{E}-03$ & $8.33 E+04$ & $1.01 \mathrm{E}+00$ \\
\hline $4.80 \mathrm{E}+02$ & $3.46 \mathrm{E}+02$ & $3.02 \mathrm{E}+02$ & $4.50 \mathrm{E}-01$ & $5.74 \mathrm{E}+02$ & $-3.63 E+01$ & $2.30 \mathrm{E}+02$ & $2.12 \mathrm{E}+02$ & 1.64E-01 & 3.32E-03 & $8.00 \mathrm{E}+04$ & 9.86E-01 \\
\hline $4.90 \mathrm{E}+02$ & $3.46 \mathrm{E}+02$ & $3.02 \mathrm{E}+02$ & $4.45 \mathrm{E}-01$ & $5.75 \mathrm{E}+02$ & $-3.66 \mathrm{E}+01$ & $2.27 \mathrm{E}+02$ & $2.10 \mathrm{E}+02$ & $1.61 \mathrm{E}-01$ & $3.28 \mathrm{E}-03$ & $7.92 \mathrm{E}+04$ & $9.81 \mathrm{E}-01$ \\
\hline $5.00 \mathrm{E}+02$ & $3.45 \mathrm{E}+02$ & $3.02 \mathrm{E}+02$ & $4.40 \mathrm{E}-01$ & $5.75 \mathrm{E}+02$ & $-3.49 \mathrm{E}+01$ & $2.24 \mathrm{E}+02$ & $2.07 \mathrm{E}+02$ & $1.58 \mathrm{E}-01$ & $3.25 \mathrm{E}-03$ & $7.83 E+04$ & $9.75 \mathrm{E}-01$ \\
\hline $5.10 \mathrm{E}+02$ & $3.45 \mathrm{E}+02$ & $3.02 \mathrm{E}+02$ & $4.35 \mathrm{E}-01$ & $5.76 \mathrm{E}+02$ & $-3.31 E+01$ & $2.21 \mathrm{E}+02$ & $2.04 \mathrm{E}+02$ & $1.56 \mathrm{E}-01$ & $22 \mathrm{E}-03$ & $7.75 \mathrm{E}+04$ & $9.70 \mathrm{E}-01$ \\
\hline $5.20 \mathrm{E}+02$ & $3.44 \mathrm{E}+02$ & $3.02 \mathrm{E}+02$ & $4.30 \mathrm{E}-01$ & $5.1 / \mathrm{E}+02$ & $-3.14 \mathrm{E}+01$ & $2.19 \mathrm{E}+02$ & $2.02 E+02$ & $1.53 \mathrm{E}-01$ & $3.18 \mathrm{E}-03$ & $7.67 E+04$ & $9.64 \mathrm{E}-01$ \\
\hline $5.30 \mathrm{E}+02$ & $3.44 \mathrm{E}+02$ & $3.02 \mathrm{E}+02$ & $4.25 \mathrm{E}-01$ & $5.77 \mathrm{E}+02$ & $-2.98 \mathrm{E}+01$ & $2.16 \mathrm{E}+02$ & $1.99 \mathrm{E}+02$ & $1.51 \mathrm{E}-01$ & $3.15 \mathrm{E}-03$ & $7.58 \mathrm{E}+04$ & $9.59 \mathrm{E}-01$ \\
\hline $5.40 \mathrm{E}+02$ & $3.43 \mathrm{E}+02$ & $3.02 \mathrm{E}+02$ & $4.20 \mathrm{E}-01$ & $5.78 \mathrm{E}+02$ & $-2.84 \mathrm{E}+01$ & $2.14 \mathrm{E}+02$ & $1.97 \mathrm{E}+02$ & $1.48 \mathrm{E}-01$ & $3.11 \mathrm{E}-03$ & $7.50 \mathrm{E}+04$ & $9.53 \mathrm{E}-01$ \\
\hline $5.50 \mathrm{E}+02$ & $3.43 \mathrm{E}+02$ & $3.02 \mathrm{E}+02$ & 4.15E-01 & $5.79 \mathrm{E}+02$ & $-2.15 \mathrm{E}+01$ & $2.12 \mathrm{E}+02$ & $1.94 \mathrm{E}+02$ & $1.51 \mathrm{E}-01$ & $3.28 \mathrm{E}-03$ & $7.92 E+04$ & 9.81E-01 \\
\hline $5.60 \mathrm{E}+02$ & $3.42 \mathrm{E}+02$ & $3.02 \mathrm{E}+02$ & 4.09E-01 & $5.80 \mathrm{E}+02$ & $-1.29 \mathrm{E}+01$ & $2.10 \mathrm{E}+02$ & $1.93 E+02$ & $1.54 \mathrm{E}-01$ & $3.46 \mathrm{E}-03$ & $8.33 E+04$ & $1.01 \mathrm{E}+00$ \\
\hline $5.70 \mathrm{E}+02$ & $3.42 \mathrm{E}+02$ & $3.02 \mathrm{E}+02$ & 4.02E-01 & $5.81 \mathrm{E}+02$ & $-6.49 \mathrm{E}+00$ & $2.09 \mathrm{E}+02$ & $1.91 \mathrm{E}+02$ & $1.58 \mathrm{E}-01$ & 3.63E-03 & $8.75 \mathrm{E}+04$ & $1.03 E+00$ \\
\hline $5.80 \mathrm{E}+02$ & $3.42 \mathrm{E}+02$ & $3.02 \mathrm{E}+02$ & 3.94E-01 & $5.82 \mathrm{E}+02$ & $-2.40 \mathrm{E}+00$ & $2.08 \mathrm{E}+02$ & $1.90 \mathrm{E}+02$ & 1.62E-01 & $3.80 \mathrm{E}-03$ & $9.17 \mathrm{E}+04$ & $1.06 \mathrm{E}+00$ \\
\hline $5.90 \mathrm{E}+02$ & $3.42 \mathrm{E}+02$ & $3.02 \mathrm{E}+02$ & $3.85 \mathrm{E}-01$ & $5.83 \mathrm{E}+02$ & $-3.57 \mathrm{E}-01$ & $2.07 \mathrm{E}+02$ & $1.89 \mathrm{E}+02$ & $1.66 \mathrm{E}-01$ & $3.98 \mathrm{E}-03$ & $9.58 \mathrm{E}+04$ & $1.08 \mathrm{E}+00$ \\
\hline
\end{tabular}


WSRC-TR-2001-00405

\begin{tabular}{|c|c|c|c|c|c|c|c|c|c|c|c|}
\hline TIME & \begin{tabular}{|c|} 
Main \\
Convec. Size
\end{tabular} & \begin{tabular}{|c|} 
Target \\
Temperature \\
(1)
\end{tabular} & $\begin{array}{l}\text { Target Flux } \\
\text { (1) }\end{array}$ & $\begin{array}{l}\text { Target Fire } \\
\text { Rad. (1) }\end{array}$ & \begin{tabular}{|c} 
Target \\
Surface Rad.
\end{tabular} & $\begin{array}{c}\text { Target Gas } \\
\text { Rad. (1) }\end{array}$ & $\begin{array}{c}\text { Target } \\
\text { Convec. (1) }\end{array}$ & \begin{tabular}{|c|} 
Target \\
Temperature \\
(2)
\end{tabular} & $\begin{array}{l}\text { Target Flux } \\
\text { (2) }\end{array}$ & $\begin{array}{l}\text { Target Fire } \\
\text { Rad. (2) }\end{array}$ & \begin{tabular}{|c} 
Target \\
Surface Rad \\
(2)
\end{tabular} \\
\hline $0.00 \mathrm{E}+00$ & $0.00 \mathrm{E}+00$ & $3.00 \mathrm{E}+02$ & \begin{tabular}{|c|}
$0.00 \mathrm{E}+00$ \\
\end{tabular} & $0.00 \mathrm{E}+00$ & $0.00 \mathrm{E}+00$ & $0.00 \mathrm{E}+00$ & $0.00 E+00$ & $3.00 \mathrm{E}+02$ & \begin{tabular}{|c|}
$4.59 \mathrm{E}+02$ \\
\end{tabular} & $0.00 \mathrm{E}+00$ & $9.61 \mathrm{E}+01$ \\
\hline $1.00 \mathrm{E}+01$ & $2.33 \mathrm{E}+04$ & $3.00 \mathrm{E}+02$ & $5.28 \mathrm{E}+02$ & $1.28 \mathrm{E}+01$ & $8.31 \mathrm{E}+01$ & \begin{tabular}{|c|}
$4.29 \mathrm{E}+00$ \\
\end{tabular} & $-1.79 \mathrm{E}-01$ & $3.00 \mathrm{E}+02$ & $4.61 \mathrm{E}+02$ & $0.00 \mathrm{E}+00$ & $9.30 \mathrm{E}+01$ \\
\hline $2.00 \mathrm{E}+01$ & $4.67 \mathrm{E}+04$ & $3.01 \mathrm{E}+02$ & $5.95 \mathrm{E}+02$ & $2.27 \mathrm{E}+01$ & $7.40 \mathrm{E}+01$ & $3.78 \mathrm{E}+00$ & $-4.30 \mathrm{E}-01$ & $3.00 \mathrm{E}+02$ & $4.65 \mathrm{E}+02$ & $0.00 \mathrm{E}+00$ & $8.88 \mathrm{E}+01$ \\
\hline $3.00 \mathrm{E}+01$ & $7.00 \mathrm{E}+04$ & $3.02 E+02$ & $6.63 \mathrm{E}+02$ & $3.06 \mathrm{E}+01$ & $6.67 \mathrm{E}+01$ & $3.38 \mathrm{E}+00$ & $-6.60 \mathrm{E}-01$ & $3.00 \mathrm{E}+02$ & $4.69 \mathrm{E}+02$ & $0.00 \mathrm{E}+00$ & $8.44 \mathrm{E}+01$ \\
\hline $4.00 \mathrm{E}+01$ & $9.33 \mathrm{E}+04$ & $3.03 E+02$ & $7.30 \mathrm{E}+02$ & $3.70 \mathrm{E}+01$ & $6.08 \mathrm{E}+01$ & $3.05 \mathrm{E}+00$ & $-8.69 \mathrm{E}-01$ & $3.00 \mathrm{E}+02$ & $4.75 \mathrm{E}+02$ & $0.00 \mathrm{E}+00$ & $7.99 \mathrm{E}+01$ \\
\hline $5.00 \mathrm{E}+01$ & $1.17 \mathrm{E}+05$ & $3.04 \mathrm{E}+02$ & \begin{tabular}{|l|}
$7.98 \mathrm{E}+02$ \\
\end{tabular} & $4.23 \mathrm{E}+01$ & $5.60 \mathrm{E}+01$ & $2.79 \mathrm{E}+00$ & $-1.06 \mathrm{E}+00$ & $3.00 \mathrm{E}+02$ & $4.83 \mathrm{E}+02$ & $0.00 \mathrm{E}+00$ & $7.54 \mathrm{E}+01$ \\
\hline $6.00 \mathrm{E}+01$ & $1.40 \mathrm{E}+05$ & $3.05 E+02$ & $8.65 \mathrm{E}+02$ & $4.68 \mathrm{E}+01$ & $5.18 \mathrm{E}+01$ & $2.56 \mathrm{E}+00$ & $-1.23 \mathrm{E}+00$ & $3.01 E+02$ & $4.92 \mathrm{E}+02$ & $0.00 \mathrm{E}+00$ & $7.11 \mathrm{E}+01$ \\
\hline $7.00 \mathrm{E}+01$ & $1.57 \mathrm{E}+05$ & $3.06 \mathrm{E}+02$ & $9.15 \mathrm{E}+02$ & $4.98 \mathrm{E}+01$ & $4.92 \mathrm{E}+01$ & $2.41 \mathrm{E}+00$ & $-1.39 \mathrm{E}+00$ & $3.01 \mathrm{E}+02$ & $5.02 \mathrm{E}+02$ & $0.00 \mathrm{E}+00$ & $6.69 \mathrm{E}+01$ \\
\hline $8.00 \mathrm{E}+01$ & $1.75 \mathrm{E}+05$ & $3.07 \mathrm{E}+02$ & $9.64 \mathrm{E}+02$ & $5.25 \mathrm{E}+01$ & $4.69 \mathrm{E}+01$ & $2.28 \mathrm{E}+00$ & $-1.62 \mathrm{E}+00$ & $3.01 \mathrm{E}+02$ & $5.14 \mathrm{E}+02$ & $0.00 \mathrm{E}+00$ & $6.30 \mathrm{E}+01$ \\
\hline $9.00 \mathrm{E}+01$ & $1.92 \mathrm{E}+05$ & $3.08 \mathrm{E}+02$ & $1.01 \mathrm{E}+03$ & $5.49 \mathrm{E}+01$ & $4.48 \mathrm{E}+01$ & $2.16 \mathrm{E}+00$ & $-1.85 \mathrm{E}+00$ & $3.01 \mathrm{E}+02$ & $5.27 \mathrm{E}+02$ & $0.00 \mathrm{E}+00$ & $5.93 \mathrm{E}+01$ \\
\hline $1.00 \mathrm{E}+02$ & $2.10 \mathrm{E}+05$ & $3.10 \mathrm{E}+02$ & $1.16 \mathrm{E}+03$ & $5.05 \mathrm{E}+01$ & $3.62 \mathrm{E}+01$ & $6.02 \mathrm{E}+00$ & $7.31 E+00$ & $3.01 \mathrm{E}+02$ & $5.42 \mathrm{E}+02$ & $0.00 \mathrm{E}+00$ & $5.57 \mathrm{E}+01$ \\
\hline $1.10 \mathrm{E}+02$ & $2.27 \mathrm{E}+05$ & $3.11 \mathrm{E}+02$ & $1.20 \mathrm{E}+03$ & $4.80 \mathrm{E}+01$ & $2.86 \mathrm{E}+01$ & $1.54 \mathrm{E}+01$ & $7.98 \mathrm{E}+00$ & $3.01 E+02$ & $5.58 \mathrm{E}+02$ & $0.00 \mathrm{E}+00$ & $5.24 \mathrm{E}+01$ \\
\hline $1.20 \mathrm{E}+02$ & $2.45 \mathrm{E}+05$ & $3.13 E+02$ & $1.24 \mathrm{E}+03$ & $4.57 \mathrm{E}+01$ & $2.38 \mathrm{E}+01$ & $2.16 \mathrm{E}+01$ & $8.77 E+00$ & $3.02 E+02$ & $5.76 \mathrm{E}+02$ & $0.00 \mathrm{E}+00$ & $4.93 \mathrm{E}+01$ \\
\hline $1.30 \mathrm{E}+02$ & $2.44 \mathrm{E}+05$ & $3.14 \mathrm{E}+02$ & $1.24 \mathrm{E}+03$ & $4.19 \mathrm{E}+01$ & $2.11 \mathrm{E}+01$ & $2.70 \mathrm{E}+01$ & $9.94 \mathrm{E}+00$ & $3.02 \mathrm{E}+02$ & $5.94 \mathrm{E}+02$ & $0.00 \mathrm{E}+00$ & $4.64 \mathrm{E}+01$ \\
\hline $1.40 \mathrm{E}+02$ & $2.43 \mathrm{E}+05$ & $3.15 \mathrm{E}+02$ & $1.24 \mathrm{E}+03$ & $3.86 \mathrm{E}+01$ & $1.90 \mathrm{E}+01$ & $3.15 \mathrm{E}+01$ & $1.10 \mathrm{E}+01$ & $3.02 E+02$ & $6.11 \mathrm{E}+02$ & $0.00 \mathrm{E}+00$ & $4.38 \mathrm{E}+01$ \\
\hline $1.50 \mathrm{E}+02$ & $2.41 \mathrm{E}+05$ & $3.16 \mathrm{E}+02$ & $1.24 \mathrm{E}+03$ & $3.56 \mathrm{E}+01$ & $1.72 \mathrm{E}+01$ & $3.53 \mathrm{E}+01$ & $1.19 \mathrm{E}+01$ & $3.02 E+02$ & $6.28 \mathrm{E}+02$ & $0.00 \mathrm{E}+00$ & $4.14 \mathrm{E}+01$ \\
\hline $1.60 \mathrm{E}+02$ & $2.40 \mathrm{E}+05$ & $3.16 E+02$ & $1.24 \mathrm{E}+03$ & $3.29 \mathrm{E}+01$ & $1.58 \mathrm{E}+01$ & $3.87 \mathrm{E}+01$ & $1.26 \mathrm{E}+01$ & $3.02 E+02$ & $6.44 \mathrm{E}+02$ & $0.00 \mathrm{E}+00$ & $3.92 \mathrm{E}+01$ \\
\hline $1.70 \mathrm{E}+02$ & $2.39 \mathrm{E}+05$ & $3.17 \mathrm{E}+02$ & $1.25 \mathrm{E}+03$ & $3.05 \mathrm{E}+01$ & $1.45 \mathrm{E}+01$ & $4.17 \mathrm{E}+01$ & $1.33 \mathrm{E}+01$ & $3.02 \mathrm{E}+02$ & $6.60 \mathrm{E}+02$ & $0.00 \mathrm{E}+00$ & $3.73 \mathrm{E}+01$ \\
\hline $1.80 \mathrm{E}+02$ & $2.38 \mathrm{E}+05$ & $3.18 \mathrm{E}+02$ & $1.26 \mathrm{E}+03$ & $2.83 \mathrm{E}+01$ & $1.35 \mathrm{E}+01$ & \begin{tabular}{|l}
$4.43 \mathrm{E}+01$ \\
\end{tabular} & $1.38 \mathrm{E}+01$ & $3.02 E+02$ & $6.75 \mathrm{E}+02$ & $0.00 \mathrm{E}+00$ & $3.55 \mathrm{E}+01$ \\
\hline $1.90 \mathrm{E}+02$ & $2.22 \mathrm{E}+05$ & $3.19 \mathrm{E}+02$ & $1.24 \mathrm{E}+03$ & $2.52 \mathrm{E}+01$ & $1.28 \mathrm{E}+01$ & $4.74 \mathrm{E}+01$ & & $3.02 E+02$ & $6.89 \mathrm{E}+02$ & $0.00 \mathrm{E}+00$ & $3.39 \mathrm{E}+01$ \\
\hline $2.00 \mathrm{E}+02$ & $2.05 \mathrm{E}+05$ & $3.19 \mathrm{E}+02$ & $1.22 \mathrm{E}+03$ & $2.25 \mathrm{E}+01$ & $1.22 \mathrm{E}+01$ & $5.02 \mathrm{E}+01$ & $1.51 \mathrm{E}+01$ & $3.02 \mathrm{E}+02$ & $7.00 \mathrm{E}+02$ & $0.00 \mathrm{E}+00$ & $3.25 \mathrm{E}+01$ \\
\hline $2.10 \mathrm{E}+02$ & $1.89 \mathrm{E}+05$ & $3.20 \mathrm{E}+02$ & $1.21 \mathrm{E}+03$ & $2.00 \mathrm{E}+01$ & $1.17 \mathrm{E}+01$ & 5.278 & & $3.02 \mathrm{E}+02$ & $7.09 \mathrm{E}+02$ & $0.00 \mathrm{E}+00$ & $3.14 \mathrm{E}+01$ \\
\hline $2.20 \mathrm{E}+02$ & $1.73 \mathrm{E}+05$ & $3.20 \mathrm{E}+02$ & $1.19 \mathrm{E}+03$ & $1.78 \mathrm{E}+01$ & $1.14 \mathrm{E}+01$ & $5.49 \mathrm{E}+01$ & $1.59 \mathrm{E}+01$ & $3.02 \mathrm{E}+02$ & $7.15 \mathrm{E}+02$ & $0.00 \mathrm{E}+00$ & $3.05 \mathrm{E}+01$ \\
\hline $2.30 \mathrm{E}+02$ & $1.56 \mathrm{E}+05$ & $3.20 \mathrm{E}+02$ & $1.17 \mathrm{E}+03$ & $1.58 \mathrm{E}+01$ & $1.11 \mathrm{E}+01$ & \begin{tabular}{|l|}
5.69 \\
\end{tabular} & +01 & $3.02 \mathrm{E}+02$ & $7.20 \mathrm{E}+02$ & $0.00 \mathrm{E}+00$ & $2.97 \mathrm{E}+01$ \\
\hline $2.40 \mathrm{E}+02$ & $1.40 \mathrm{E}+05$ & $3.21 \mathrm{E}+02$ & $1.15 \mathrm{E}+03$ & $1.40 \mathrm{E}+01$ & $1.09 \mathrm{E}+01$ & \begin{tabular}{|l}
$5.88 \mathrm{E}+01$ \\
\end{tabular} & $1.63 \mathrm{E}+01$ & $3.02 \mathrm{E}+02$ & $7.22 \mathrm{E}+02$ & $0.00 \mathrm{E}+00$ & $2.91 \mathrm{E}+01$ \\
\hline $2.50 \mathrm{E}+02$ & $1.34 \mathrm{E}+05$ & $3.21 \mathrm{E}+02$ & $1.14 \mathrm{E}+03$ & $1.31 \mathrm{E}+01$ & $1.07 \mathrm{E}+01$ & \begin{tabular}{|l}
5.99 \\
\end{tabular} & $1.63 \mathrm{E}+01$ & $3.02 E+02$ & $7.24 \mathrm{E}+02$ & $0.00 \mathrm{E}+00$ & $2.86 \mathrm{E}+01$ \\
\hline $2.60 \mathrm{E}+02$ & $1.28 \mathrm{E}+05$ & $3.21 \mathrm{E}+02$ & $1.13 \mathrm{E}+03$ & $1.24 \mathrm{E}+01$ & $1.05 \mathrm{E}+01$ & $6.09 \mathrm{E}+01$ & $1.62 \mathrm{E}+01$ & $3.02 \mathrm{E}+02$ & $7.26 \mathrm{E}+02$ & $0.00 \mathrm{E}+00$ & $2.82 \mathrm{E}+01$ \\
\hline $2.70 \mathrm{E}+02$ & $1.22 \mathrm{E}+05$ & $3.21 \mathrm{E}+02$ & $1.12 \mathrm{E}+03$ & $1.17 \mathrm{E}+01$ & $1.04 \mathrm{E}+01$ & \begin{tabular}{|l|}
6.18 \\
\end{tabular} & $1.62 \mathrm{E}+01$ & $3.02 \mathrm{E}+02$ & $7.28 \mathrm{E}+02$ & $0.00 \mathrm{E}+00$ & $2.79 \mathrm{E}+01$ \\
\hline $2.80 \mathrm{E}+02$ & $1.17 \mathrm{E}+05$ & $3.21 \mathrm{E}+02$ & $1.11 \mathrm{E}+03$ & $1.10 \mathrm{E}+01$ & $1.03 \mathrm{E}+01$ & $6.26 \mathrm{E}+01$ & $1.61 \mathrm{E}+01$ & $3.02 \mathrm{E}+02$ & $7.29 \mathrm{E}+02$ & $0.00 \mathrm{E}+00$ & $2.76 \mathrm{E}+01$ \\
\hline $2.90 \mathrm{E}+02$ & $1.11 \mathrm{E}+05$ & $3.22 \mathrm{E}+02$ & $1.10 \mathrm{E}+03$ & $1.04 \mathrm{E}+01$ & $1.02 \mathrm{E}+01$ & \begin{tabular}{|c|}
$6.34 \mathrm{E}+01$ \\
\end{tabular} & $1.60 \mathrm{E}+01$ & $3.02 \mathrm{E}+02$ & $7.29 \mathrm{E}+02$ & $0.00 \mathrm{E}+00$ & $2.73 \mathrm{E}+01$ \\
\hline $3.00 \mathrm{E}+02$ & $1.05 \mathrm{E}+05$ & $3.22 \mathrm{E}+02$ & $1.09 \mathrm{E}+03$ & $9.79 \mathrm{E}+00$ & $1.01 \mathrm{E}+01$ & \begin{tabular}{|l}
$6.41 \mathrm{E}+01$ \\
\end{tabular} & $1.59 \mathrm{E}+01$ & $3.02 \mathrm{E}+02$ & $7.29 \mathrm{E}+02$ & $0.00 \mathrm{E}+00$ & $2.71 \mathrm{E}+01$ \\
\hline $3.10 \mathrm{E}+02$ & $9.92 \mathrm{E}+04$ & $3.22 \mathrm{E}+02$ & $1.08 \mathrm{E}+03$ & $9.23 \mathrm{E}+00$ & $1.01 \mathrm{E}+01$ & $6.49 \mathrm{E}+01$ & $1.58 \mathrm{E}+01$ & $3.02 \mathrm{E}+02$ & $7.28 \mathrm{E}+02$ & $0.00 \mathrm{E}+00$ & $2.70 \mathrm{E}+01$ \\
\hline $3.20 \mathrm{E}+02$ & $9.33 \mathrm{E}+04$ & $3.22 \mathrm{E}+02$ & $1.06 \mathrm{E}+03$ & $8.68 \mathrm{E}+00$ & $1.01 \mathrm{E}+01$ & $6.55 \mathrm{E}+01$ & $1.57 \mathrm{E}+01$ & $3.02 \mathrm{E}+02$ & $7.27 \mathrm{E}+02$ & $0.00 \mathrm{E}+00$ & $2.69 \mathrm{E}+01$ \\
\hline $3.30 \mathrm{E}+02$ & $8.75 \mathrm{E}+04$ & $3.22 \mathrm{E}+02$ & $1.05 \mathrm{E}+03$ & $8.16 \mathrm{E}+00$ & $1.01 \mathrm{E}+01$ & $6.62 \mathrm{E}+01$ & $1.55 \mathrm{E}+01$ & $3.02 \mathrm{E}+02$ & $7.25 \mathrm{E}+02$ & $0.00 \mathrm{E}+00$ & $2.68 \mathrm{E}+01$ \\
\hline $3.40 \mathrm{E}+02$ & $8.17 \mathrm{E}+04$ & $3.22 \mathrm{E}+02$ & $1.04 \mathrm{E}+03$ & $7.65 \mathrm{E}+00$ & $1.02 \mathrm{E}+01$ & \begin{tabular}{|l}
$6.68 \mathrm{E}+01$ \\
\end{tabular} & $1.54 \mathrm{E}+01$ & $3.02 \mathrm{E}+02$ & $7.23 E+02$ & $0.00 \mathrm{E}+00$ & $2.68 \mathrm{E}+01$ \\
\hline $3.50 \mathrm{E}+02$ & $7.58 \mathrm{E}+04$ & $3.22 \mathrm{E}+02$ & $1.02 \mathrm{E}+03$ & $7.15 \mathrm{E}+00$ & $1.02 \mathrm{E}+01$ & \begin{tabular}{|l}
$6.75 \mathrm{E}+01$ \\
\end{tabular} & $1.52 \mathrm{E}+01$ & $3.02 \mathrm{E}+02$ & $7.20 \mathrm{E}+02$ & $0.00 \mathrm{E}+00$ & $2.67 \mathrm{E}+01$ \\
\hline $3.60 \mathrm{E}+02$ & $7.00 \mathrm{E}+04$ & $3.22 \mathrm{E}+02$ & $1.01 \mathrm{E}+03$ & $6.65 \mathrm{E}+00$ & $1.03 \mathrm{E}+01$ & $6.81 \mathrm{E}+01$ & $1.50 \mathrm{E}+01$ & $3.02 \mathrm{E}+02$ & $7.17 \mathrm{E}+02$ & $0.00 \mathrm{E}+00$ & $2.68 \mathrm{E}+01$ \\
\hline $3.70 \mathrm{E}+02$ & $7.00 \mathrm{E}+04$ & $3.22 \mathrm{E}+02$ & $9.99 \mathrm{E}+02$ & $6.68 \mathrm{E}+00$ & $1.03 \mathrm{E}+01$ & \begin{tabular}{|l}
$6.83 \mathrm{E}+01$ \\
\end{tabular} & $1.47 \mathrm{E}+01$ & $3.02 \mathrm{E}+02$ & $7.13 \mathrm{E}+02$ & $0.00 \mathrm{E}+00$ & $2.68 \mathrm{E}+01$ \\
\hline $3.80 \mathrm{E}+02$ & $7.00 \mathrm{E}+04$ & $3.22 \mathrm{E}+02$ & \begin{tabular}{|c|}
$9.90 \mathrm{E}+02$ \\
\end{tabular} & $70 \mathrm{E}+00$ & $1.04 \mathrm{E}+01$ & $6.85 \mathrm{E}+01$ & $1.44 \mathrm{E}+01$ & $3.02 \mathrm{E}+02$ & $7.10 \mathrm{E}+02$ & $0.00 \mathrm{E}+00$ & $2.69 \mathrm{E}+01$ \\
\hline $3.90 \mathrm{E}+02$ & $7.00 \mathrm{E}+04$ & $3.22 \mathrm{E}+02$ & $9.82 \mathrm{E}+02$ & $6.71 \mathrm{E}+00$ & $1.04 \mathrm{E}+01$ & \begin{tabular}{|c|}
$6.87 \mathrm{E}+01$ \\
\end{tabular} & $1.42 \mathrm{E}+01$ & $3.02 \mathrm{E}+02$ & $7.07 E+02$ & $0.00 \mathrm{E}+00$ & $2.69 \mathrm{E}+01$ \\
\hline $4.00 \mathrm{E}+02$ & $7.00 \mathrm{E}+04$ & $322 \mathrm{~F}+2$ & $975 \mathrm{~F}+02$ & $673 E_{0}+0$ & $104 \mathrm{~F}+01$ & 6 G00 1 & +01 & $3.02 \mathrm{E}+02$ & $7.05 E+02$ & $0.00 \mathrm{E}+00$ & $2.69 \mathrm{E}+01$ \\
\hline $4.10 \mathrm{E}+02$ & $7.00 \mathrm{E}+04$ & $3.22 \mathrm{E}+02$ & $9.67 \mathrm{E}+02$ & $6.74 \mathrm{E}+00$ & $1.04 \mathrm{E}+01$ & $6.92 \mathrm{E}+01$ & $1.37 \mathrm{E}+01$ & $3.02 \mathrm{E}+02$ & $7.02 E+02$ & $0.00 \mathrm{E}+00$ & $2.70 \mathrm{E}+01$ \\
\hline $4.20 \mathrm{E}+02$ & $7.00 \mathrm{E}+04$ & $322 E+02$ & $9.61 \mathrm{E}+02$ & $675 F^{2}+0$ & $1.04 \mathrm{E}+01$ & $6.94 \mathrm{E}+01$ & 001 & $3.02 \mathrm{E}+02$ & $7.00 \mathrm{E}+02$ & $0.00 \mathrm{E}+00$ & $2.70 \mathrm{E}+01$ \\
\hline $4.30 \mathrm{E}+02$ & $6.77 \mathrm{E}+04$ & $3.22 \mathrm{E}+02$ & $9.52 \mathrm{E}+02$ & $6.55 \mathrm{E}+00$ & $1.05 E+01$ & $6.97 \mathrm{E}+01$ & $1.33 \mathrm{E}+01$ & $3.02 \mathrm{E}+02$ & $6.97 \mathrm{E}+02$ & $0.00 \mathrm{E}+00$ & $2.70 \mathrm{E}+01$ \\
\hline $4.40 \mathrm{E}+02$ & $6.53 \mathrm{E}+04$ & & \begin{tabular}{|c|}
$9.43 \mathrm{E}+02$ \\
\end{tabular} & $635 F+00$ & & & & $3.02 \mathrm{E}+02$ & $6.95 \mathrm{E}+02$ & & \\
\hline $4.50 \mathrm{E}+02$ & $6.30 \mathrm{E}+04$ & $3.22 \mathrm{E}+02$ & $9.34 \mathrm{E}+02$ & $6.15 \mathrm{E}+00$ & $1.06 \mathrm{E}+01$ & \begin{tabular}{|c|}
$7.04 \mathrm{E}+01$ \\
\end{tabular} & $1.29 \mathrm{E}+01$ & $3.02 \mathrm{E}+02$ & $6.92 \mathrm{E}+02$ & $0.00 \mathrm{E}+00$ & $2.71 \mathrm{E}+01$ \\
\hline $4.60 \mathrm{E}+02$ & & & & $596 \mathrm{~F}+0$ & $1.06 \mathrm{E}+01$ & $7.08 \mathrm{E}+01$ & & $3.02 \mathrm{E}+02$ & $6.89 \mathrm{E}+02$ & & \\
\hline $4.70 \mathrm{E}+02$ & $5.83 \mathrm{E}+04$ & $3.22 \mathrm{E}+02$ & $9.16 \mathrm{E}+02$ & $5.76 \mathrm{E}+00$ & $1.07 \mathrm{E}+01$ & $7.11 \mathrm{E}+01$ & $1.25 \mathrm{E}+01$ & $3.02 E+02$ & $6.87 \mathrm{E}+02$ & $0.00 \mathrm{E}+00$ & $2.72 \mathrm{E}+01$ \\
\hline $4.80 \mathrm{E}+02$ & $5.60 \mathrm{E}+04$ & & & & & & & $3.02 \mathrm{E}+02$ & $6.84 \mathrm{E}+02$ & & \\
\hline $4.90 \mathrm{E}+02$ & $5.54 \mathrm{E}+04$ & $3.22 \mathrm{E}+02$ & $9.00 \mathrm{E}+02$ & $5.54 \mathrm{E}+00$ & $1.08 \mathrm{E}+01$ & \begin{tabular}{|l}
$7.16 \mathrm{E}+01$ \\
\end{tabular} & $1.21 \mathrm{E}+01$ & $3.02 E+02$ & $6.81 \mathrm{E}+02$ & $0.00 \mathrm{E}+00$ & $2.73 \mathrm{E}+01$ \\
\hline $5.00 \mathrm{E}+02$ & $5.48 \mathrm{E}+04$ & & & $5.50 \mathrm{E}+00$ & & & & $3.02 \mathrm{E}+02$ & $6.78 \mathrm{E}+02$ & $0.00 \mathrm{E}+00$ & $2.74 \mathrm{E}+01$ \\
\hline $5.10 \mathrm{E}+02$ & $5.42 \mathrm{E}+04$ & $3.22 \mathrm{E}+02$ & $8.86 \mathrm{E}+02$ & $5.47 \mathrm{E}+00$ & $1.09 \mathrm{E}+01$ & $7.20 \mathrm{E}+01$ & $1.16 \mathrm{E}+01$ & $3.02 E+02$ & $6.75 \mathrm{E}+02$ & $0.00 \mathrm{E}+00$ & $2.74 \mathrm{E}+01$ \\
\hline $5.20 \mathrm{E}+02$ & $5.37 \mathrm{E}+04$ & $3.22 \mathrm{E}+02$ & $8.79 \mathrm{E}+02$ & $5.44 \mathrm{E}+00$ & $1.09 \mathrm{E}+01$ & $7.22 \mathrm{E}+01$ & & $3.02 \mathrm{E}+02$ & $6.73 \mathrm{E}+02$ & $.00 \mathrm{E}+00$ & $2.75 E+01$ \\
\hline $5.30 \mathrm{E}+02$ & $5.31 \mathrm{E}+04$ & $3.22 \mathrm{E}+02$ & $8.73 \mathrm{E}+02$ & $5.40 \mathrm{E}+00$ & $1.10 \mathrm{E}+01$ & $7.24 \mathrm{E}+01$ & $1.12 \mathrm{E}+01$ & $3.02 E+02$ & $6.70 E+02$ & $0.00 \mathrm{E}+00$ & $2.75 \mathrm{E}+01$ \\
\hline $5.40 \mathrm{E}+02$ & $5.25 \mathrm{E}+04$ & $3.22 \mathrm{E}+02$ & $8.67 \mathrm{E}+02$ & $5.36 \mathrm{E}+00$ & $1.10 \mathrm{E}+01$ & $7.25 \mathrm{E}+01$ & $1.11 \mathrm{E}+01$ & $3.02 \mathrm{E}+02$ & $6.68 \mathrm{E}+02$ & $0.00 \mathrm{E}+00$ & $2.76 \mathrm{E}+01$ \\
\hline $5.50 \mathrm{E}+02$ & $5.54 \mathrm{E}+04$ & $3.22 \mathrm{E}+02$ & $8.64 \mathrm{E}+02$ & $5.66 \mathrm{E}+00$ & $1.10 \mathrm{E}+01$ & $7.25 \mathrm{E}+01$ & $1.08 \mathrm{E}+01$ & $3.02 \mathrm{E}+02$ & $6.66 \mathrm{E}+02$ & $0.00 \mathrm{E}+00$ & $2.76 \mathrm{E}+01$ \\
\hline $5.60 \mathrm{E}+02$ & $5.83 \mathrm{E}+04$ & $3.22 \mathrm{E}+02$ & $8.62 \mathrm{E}+02$ & $5.95 \mathrm{E}+00$ & $1.10 \mathrm{E}+01$ & $7.24 \mathrm{E}+01$ & $1.06 \mathrm{E}+01$ & $3.02 \mathrm{E}+02$ & $6.64 \mathrm{E}+02$ & $.00 \mathrm{E}+00$ & $2.77 \mathrm{E}+01$ \\
\hline $5.70 \mathrm{E}+02$ & $6.12 \mathrm{E}+04$ & $3.22 \mathrm{E}+02$ & $8.61 \mathrm{E}+02$ & $6.22 \mathrm{E}+00$ & $1.10 \mathrm{E}+01$ & $7.23 \mathrm{E}$. & $1.05 \mathrm{E}+01$ & $3.02 \mathrm{E}+02$ & $6.63 \mathrm{E}+02$ & $0.00 \mathrm{E}+00$ & $.77 \mathrm{E}+01$ \\
\hline $5.80 \mathrm{E}+02$ & $6.42 \mathrm{E}+04$ & $3.22 \mathrm{E}+02$ & $8.61 \mathrm{E}+02$ & $6.49 \mathrm{E}+00$ & $1.09 \mathrm{E}+01$ & $7.23 \mathrm{E}+01$ & 1.03 & $3.02 \mathrm{E}+02$ & $6.62 \mathrm{E}+02$ & $0.00 \mathrm{E}+00$ & $2.77 \mathrm{E}+01$ \\
\hline+02 & $6.71 \mathrm{E}+04$ & $3.22 \mathrm{E}+02$ & $8.61 \mathrm{E}+02$ & $6.74 \mathrm{E}+00$ & 1.0 & 1.2 & 01 & $3.02 \mathrm{E}+02$ & $6.61 \mathrm{E}+02$ & 00 & \\
\hline
\end{tabular}


WSRC-TR-2001-00405

\begin{tabular}{|c|c|c|c|c|c|c|c|c|c|c|c|}
\hline TIME & $\begin{array}{c}\text { Target Gas } \\
\text { Rad. (2) } \\
\end{array}$ & $\begin{array}{c}\text { Target } \\
\text { Convec. (2) } \\
\end{array}$ & Upper N2 (1) & 2 (1) & $\begin{array}{c}\text { Upper CO2 } \\
\text { (1) } \\
\end{array}$ & Upper CO (1) & $\begin{array}{c}\text { Upper HCN } \\
\text { (1) } \\
\end{array}$ & \begin{tabular}{|c|} 
Upper HCL \\
(1) \\
\end{tabular} & \begin{tabular}{|c}
$\begin{array}{c}\text { Upper TUHC } \\
(1)\end{array}$ \\
\end{tabular} & \begin{tabular}{|c|} 
Upper $\mathrm{H} 2 \mathrm{O}$ \\
$(1)$
\end{tabular} & Upper OD (1 \\
\hline $0.00 E+00$ & $3.92 \mathrm{E}+00$ & $0.00 \mathrm{E}+00$ & $7.77 E+01$ & $2.05 E+01$ & $0.00 \mathrm{E}+00$ & $0.00 \mathrm{E}+00$ & $0.00 \mathrm{E}+00$ & $0.00 \mathrm{E}+00$ & $0.00 \mathrm{E}+00$ & $1.75 E+00$ & $0.00 \mathrm{E}+00$ \\
\hline $1.00 \mathrm{E}+01$ & $7.01 \mathrm{E}+00$ & $-1.55 \mathrm{E}-02$ & $7.77 \mathrm{E}+01$ & $2.05 E+01$ & $1.87 \mathrm{E}-02$ & $0.00 \mathrm{E}+00$ & $0.00 \mathrm{E}+00$ & $0.00 \mathrm{E}+00$ & $0.00 \mathrm{E}+00$ & $1.78 \mathrm{E}+00$ & $0.00 \mathrm{E}+00$ \\
\hline $2.00 \mathrm{E}+01$ & $1.12 \mathrm{E}+01$ & $-3.10 \mathrm{E}-02$ & $7.77 \mathrm{E}+01$ & $2.05 \mathrm{E}+01$ & $3.34 \mathrm{E}-02$ & $0.00 \mathrm{E}+00$ & $0.00 \mathrm{E}+00$ & $0.00 \mathrm{E}+00$ & $0.00 \mathrm{E}+00$ & $1.81 \mathrm{E}+00$ & $0.00 \mathrm{E}+00$ \\
\hline $3.00 \mathrm{E}+01$ & $1.57 \mathrm{E}+01$ & $-4.01 \mathrm{E}-02$ & $7.77 \mathrm{E}+01$ & $2.04 \mathrm{E}+01$ & $4.87 \mathrm{E}-02$ & $0.00 \mathrm{E}+00$ & $0.00 \mathrm{E}+00$ & $0.00 \mathrm{E}+00$ & $0.00 \mathrm{E}+00$ & $1.84 \mathrm{E}+00$ & $0.00 \mathrm{E}+00$ \\
\hline $4.00 \mathrm{E}+01$ & $2.02 \mathrm{E}+01$ & $-4.12 \mathrm{E}-02$ & $7.77 E+01$ & $2.04 E+01$ & $6.52 \mathrm{E}-02$ & $0.00 \mathrm{E}+00$ & $0.00 \mathrm{E}+00$ & $.00 \mathrm{E}+00$ & $0.00 \mathrm{E}+00$ & $1.87 \mathrm{E}+00$ & $0.00 \mathrm{E}+00$ \\
\hline $5.00 \mathrm{E}+01$ & $2.46 \mathrm{E}+01$ & $-3.40 \mathrm{E}-02$ & $7.76 \mathrm{E}+01$ & $2.04 E+01$ & $8.30 \mathrm{E}-02$ & $0.00 \mathrm{E}+00$ & $0.00 \mathrm{E}+00$ & $.00 \mathrm{E}+00$ & $0.00 \mathrm{E}+00$ & $1.90 \mathrm{E}+00$ & $0.00 \mathrm{E}+00$ \\
\hline $6.00 \mathrm{E}+01$ & $2.89 \mathrm{E}+01$ & $-1.88 \mathrm{E}-02$ & $7.76 \mathrm{E}+01$ & $2.03 E+01$ & $1.02 \mathrm{E}-01$ & $0.00 \mathrm{E}+00$ & $0.00 \mathrm{E}+00$ & $00 \mathrm{E}+00$ & $0.00 \mathrm{E}+00$ & $.94 \mathrm{E}+00$ & $0.00 \mathrm{E}+00$ \\
\hline $7.00 E+01$ & $3.31 \mathrm{E}+01$ & $1.49 \mathrm{E}-03$ & $7.76 \mathrm{E}+01$ & $2.03 E+01$ & $1.23 \mathrm{E}-01$ & $0.00 \mathrm{E}+00$ & $0.00 \mathrm{E}+00$ & $00 \mathrm{E}+00$ & $0.00 \mathrm{E}+00$ & $1.98 \mathrm{E}+00$ & $0.00 E+00$ \\
\hline $8.00 \mathrm{E}+01$ & $3.70 \mathrm{E}+01$ & $2.06 \mathrm{E}-02$ & $7.76 \mathrm{E}+01$ & $2.03 \mathrm{E}+01$ & 1.44E-01 & $0.00 \mathrm{E}+00$ & $0.00 \mathrm{E}+00$ & $00 \mathrm{E}+00$ & $0.00 \mathrm{E}+00$ & $.02 \mathrm{E}+00$ & $0.00 \mathrm{E}+00$ \\
\hline $9.00 \mathrm{E}+01$ & $4.07 \mathrm{E}+01$ & $3.92 \mathrm{E}-02$ & $7.75 E+01$ & $2.02 \mathrm{E}+01$ & $1.67 \mathrm{E}-01$ & $0.00 \mathrm{E}+00$ & $0.00 \mathrm{E}+00$ & $.00 \mathrm{E}+00$ & $0.00 \mathrm{E}+00$ & $2.06 \mathrm{E}+00$ & $0.00 \mathrm{E}+00$ \\
\hline $1.00 \mathrm{E}+02$ & $4.42 \mathrm{E}+01$ & $5.74 \mathrm{E}-02$ & $7.75 \mathrm{E}+01$ & $2.02 \mathrm{E}+01$ & $91 \mathrm{E}-01$ & $0.00 \mathrm{E}+00$ & $0.00 \mathrm{E}+00$ & $00 \mathrm{E}+00$ & $0.00 \mathrm{E}+00$ & $2.11 \mathrm{E}+00$ & $0.00 \mathrm{E}+00$ \\
\hline $1.10 \mathrm{E}+02$ & $4.75 \mathrm{E}+01$ & $7.48 \mathrm{E}-02$ & $5 \bar{E}+01$ & $2.01 \mathrm{E}+01$ & $6 \mathrm{E}-01$ & $0 \mathrm{E}+00$ & & $0 \mathrm{E}+00$ & $0.00 \mathrm{E}+00$ & +00 & $0.00 \mathrm{E}+00$ \\
\hline $1.20 \mathrm{E}+02$ & $5.06 \mathrm{E}+01$ & $9.08 \mathrm{E}-02$ & $7.75 \mathrm{E}+01$ & $2.01 \mathrm{E}+01$ & $43 \mathrm{E}-01$ & $0.00 \mathrm{E}+00$ & $0.00 \mathrm{E}+00$ & $0.00 \mathrm{E}+00$ & $0.00 \mathrm{E}+00$ & $2.21 \mathrm{E}+00$ & $0.00 \mathrm{E}+00$ \\
\hline $1.30 \mathrm{E}+02$ & $5.35 \mathrm{E}+01$ & $1.00 \mathrm{E}-01$ & $7.74 \mathrm{E}+01$ & $2.00 \mathrm{E}+01$ & $2.70 \mathrm{E}-01$ & $0.00 \mathrm{E}+00$ & 100 & $.00 \mathrm{E}+00$ & $.00 \mathrm{E}+00$ & +00 & $0.00 \mathrm{E}+00$ \\
\hline $1.40 \mathrm{E}+02$ & $5.62 \mathrm{E}+01$ & $8.73 \mathrm{E}-02$ & $7.74 \mathrm{E}+01$ & $2.00 \mathrm{E}+01$ & $2.96 \mathrm{E}-01$ & $0.00 \mathrm{E}+00$ & $0.00 \mathrm{E}+00$ & $.00 \mathrm{E}+00$ & $0.00 \mathrm{E}+00$ & $2.31 \mathrm{E}+00$ & $0.00 \mathrm{E}+00$ \\
\hline $1.50 \mathrm{E}+02$ & $5.86 \mathrm{E}+01$ & $5.93 \mathrm{E}-02$ & $7.74 \mathrm{E}+01$ & $1.99 \mathrm{E}+01$ & $3.21 \mathrm{E}-01$ & $0.00 \mathrm{E}+00$ & $0.00 \mathrm{E}+00$ & $0.00 \mathrm{E}+00$ & $0.00 \mathrm{E}+00$ & $2.35 \mathrm{E}+00$ & $0.00 \mathrm{E}+00$ \\
\hline $1.60 \mathrm{E}+02$ & & $2.19 \mathrm{E}-02$ & & $1.99 \mathrm{E}+01$ & & $0.00 \mathrm{E}+00$ & & $\mathrm{E}+00$ & $0.00 \mathrm{E}+00$ & & $0.00 \mathrm{E}+00$ \\
\hline $1.70 \mathrm{E}+02$ & $6.28 \mathrm{E}+01$ & $-2.10 \mathrm{E}-02$ & $7.73 \mathrm{E}+01$ & $1.98 \mathrm{E}+01$ & $3.68 \mathrm{E}-01$ & $0.00 \mathrm{E}+00$ & $0.00 \mathrm{E}+00$ & $0.00 \mathrm{E}+00$ & $0.00 \mathrm{E}+00$ & $2.44 \mathrm{E}+00$ & $0.00 \mathrm{E}+00$ \\
\hline $1.80 \mathrm{E}+02$ & & $-6.61 \mathrm{E}-02$ & & $1.98 \mathrm{E}+01$ & & $0.00 \mathrm{E}+00$ & & $.00 \mathrm{E}+00$ & $0.00 \mathrm{E}+00$ & & $0.00 \mathrm{E}+00$ \\
\hline $1.90 \mathrm{E}+02$ & $6.63 \mathrm{E}+01$ & $-1.15 \mathrm{E}-01$ & $7.73 E+01$ & $1.98 \mathrm{E}+01$ & $4.12 \mathrm{E}-01$ & $0.00 \mathrm{E}+00$ & $0.00 \mathrm{E}+00$ & $.00 \mathrm{E}+00$ & $0.00 \mathrm{E}+00$ & $2.52 \mathrm{E}+00$ & $0.00 \mathrm{E}+00$ \\
\hline $2.00 \mathrm{E}+02$ & & $-1.78 \mathrm{E}-01$ & & $1.97 \mathrm{E}+01$ & & $0.00 \mathrm{E}+00$ & & $00 \mathrm{E}+00$ & $0.00 \mathrm{E}+00$ & & $0.00 \mathrm{E}+00$ \\
\hline $2.10 \mathrm{E}+02$ & $6.89 \mathrm{E}+01$ & $-2.47 \mathrm{E}-01$ & $7.73 \mathrm{E}+01$ & $1.97 \mathrm{E}+01$ & $\mathrm{E}-01$ & $0.00 \mathrm{E}+00$ & & $\mathrm{E}+00$ & $0.00 \mathrm{E}+00$ & $2.59 E+00$ & $0.00 \mathrm{E}+00$ \\
\hline $2.20 \mathrm{E}+02$ & & $-3.16 \mathrm{E}-01$ & & $1.97 \mathrm{E}+01$ & & $.00 \mathrm{E}+00$ & & $E+00$ & $0.00 \mathrm{E}+00$ & & $0.00 \mathrm{E}+00$ \\
\hline $2.30 \mathrm{E}+02$ & & $-3.79 \mathrm{E}-01$ & $7.72 \mathrm{E}+01$ & $1.96 \mathrm{E}+01$ & $E-01$ & $.00 \mathrm{E}+00$ & & $E+00$ & $0.00 \mathrm{E}+00$ & & $E+00$ \\
\hline $2.40 \mathrm{E}+02$ & & $-4.30 \mathrm{E}-01$ & $7.72 E+01$ & $1.96 \mathrm{E}+01$ & $4.91 \mathrm{E}-01$ & $0.00 \mathrm{E}+00$ & 100 & $\mathrm{E}+00$ & $0.00 \mathrm{E}+00$ & & $0.00 \mathrm{E}+00$ \\
\hline $2.50 \mathrm{E}+02$ & & & & $1.96 \mathrm{E}+01$ & & $0.00 \mathrm{E}+00$ & & & $0 \mathrm{E}+00$ & & $E+00$ \\
\hline $2.60 \mathrm{E}+02$ & $7.22 \mathrm{E}+01$ & $-4.66 \mathrm{E}-01$ & $7.72 E+01$ & $1.96 \mathrm{E}+01$ & $5.13 \mathrm{E}-01$ & $0.00 \mathrm{E}+00$ & $0.00 \mathrm{E}+00$ & $.00 \mathrm{E}+00$ & $0.00 \mathrm{E}+00$ & $2.72 \mathrm{E}+00$ & $0.00 \mathrm{E}+00$ \\
\hline $2.70 E+02$ & $7.26 \mathrm{E}+01$ & $-4.54 \mathrm{E}-01$ & $72 E+01$ & $1.96 \mathrm{E}+01$ & $\mathrm{E}-01$ & $0.00 \mathrm{E}+00$ & $0.00 \mathrm{E}+00$ & $00 \mathrm{E}+00$ & $0.00 \mathrm{E}+00$ & \pm 00 & $0.00 \mathrm{E}+00$ \\
\hline $2.80 \mathrm{E}+02$ & $7.28 \mathrm{E}+01$ & $-4.33 \mathrm{E}-01$ & $7.72 E+01$ & $1.95 \mathrm{E}+01$ & -01 & $0.00 \mathrm{E}+00$ & $00 \mathrm{E}+00$ & $00 \mathrm{E}+00$ & $0.00 \mathrm{E}+00$ & \pm 00 & $0.00 \mathrm{E}+00$ \\
\hline $2.90 \mathrm{E}+02$ & $7.31 \mathrm{E}+01$ & $-4.09 \mathrm{E}-01$ & +01 & $1.95 \mathrm{E}+01$ & & $0.00 \mathrm{E}+00$ & & $\mathrm{DE}+00$ & $0.00 \mathrm{E}+00$ & \pm 00 & $0.00 \mathrm{E}+00$ \\
\hline $3.00 \mathrm{E}+02$ & 01 & $-3.84 \mathrm{E}-01$ & 01 & +01 & & $\mathrm{E}+00$ & & $E+00$ & $0.00 \mathrm{E}+00$ & +00 & $0.00 \mathrm{E}+00$ \\
\hline $3.10 \mathrm{E}+02$ & & & & & & +00 & & $E+00$ & $E+00$ & & $E+00$ \\
\hline $3.20 \mathrm{E}+02$ & & -01 & & 01 & & $0.00 \mathrm{E}+00$ & & $E+00$ & $0.00 \mathrm{E}+00$ & & $E+00$ \\
\hline $3.30 \mathrm{E}+02$ & +01 & $-3.12 \mathrm{E}-01$ & +01 & $1.95 \mathrm{E}+01$ & -01 & $0.00 \mathrm{E}+00$ & $00 \mathrm{E}+00$ & $\mathrm{E}+00$ & $0.00 \mathrm{E}+00$ & $2.83 \mathrm{E}+00$ & $0.00 \mathrm{E}+00$ \\
\hline $3.40 \mathrm{E}+02$ & & $E-01$ & & & & $0.00 \mathrm{E}+00$ & & $E+00$ & $\mathrm{OE}+00$ & & $E+00$ \\
\hline $3.50 \mathrm{E}+02$ & $7.35 \mathrm{E}+01$ & $-2.75 \mathrm{E}-01$ & $7.71 \mathrm{E}+01$ & $1.94 \mathrm{E}+01$ & $E-01$ & $0.00 \mathrm{E}+00$ & $0.00 \mathrm{E}+00$ & $0.00 \mathrm{E}+00$ & $0.00 \mathrm{E}+00$ & $2.86 \mathrm{E}+00$ & $0.00 \mathrm{E}+00$ \\
\hline & & & & & & & & & & & \\
\hline $3.70 \mathrm{E}+02$ & 01 & $-2.46 \mathrm{E}-01$ & 01 & 1.94 & 01 & $.00 \mathrm{E}+00$ & 100 & $\mathrm{DE}+00$ & $0.00 \mathrm{E}+00$ & +00 & $0.00 \mathrm{E}+00$ \\
\hline & & & & & & & & & & & \\
\hline $3.90 \mathrm{E}+02$ & & -2 & & 1. & & -00 & & +00 & $.00 \mathrm{E}+00$ & & $E+00$ \\
\hline 4.00 & & -01 & & 1.94 & & $0.00 \mathrm{E}+00$ & & & $0.00 \mathrm{E}+00$ & & $E+00$ \\
\hline $4.10 \mathrm{E}+02$ & & & & $1.94 \mathrm{E}+01$ & & $.00 \mathrm{E}+00$ & & $E+00$ & $0.00 \mathrm{E}+00$ & & $0.00 \mathrm{E}+00$ \\
\hline $4.20 \mathrm{E}+02$ & & $-1.96 \mathrm{E}-01$ & 01 & $1.94 \mathrm{E}+01$ & $4 \mathrm{E}-01$ & $0.00 \mathrm{E}+00$ & $0.00 \mathrm{E}+00$ & $00 \mathrm{E}+00$ & $0.00 \mathrm{E}+00$ & $93 \mathrm{E}+00$ & $E+00$ \\
\hline $4.30 \mathrm{E}+02$ & & & & & & & & & & & \\
\hline $4.40 \mathrm{E}+02$ & $7.32 \mathrm{E}+01$ & $-1.81 \mathrm{E}-01$ & $7.71 E+01$ & $1.93 \mathrm{E}+01$ & 34E-01 & $0.00 \mathrm{E}+00$ & $00 \mathrm{E}+00$ & $0.00 \mathrm{E}+00$ & $0.00 \mathrm{E}+00$ & $2.94 \mathrm{E}+00$ & $0.00 \mathrm{E}+00$ \\
\hline & & & & & & & & & & & \\
\hline $4.60 \mathrm{E}+02$ & $E+01$ & $-1.68 \mathrm{E}-01$ & +01 & $1.93 \mathrm{E}+01$ & $E-01$ & $0.00 \mathrm{E}+00$ & +00 & $.00 \mathrm{E}+00$ & $0.00 \mathrm{E}+00$ & $2.96 \mathrm{E}+00$ & $0.00 \mathrm{E}+00$ \\
\hline & & & & & & & & & & & \\
\hline $4.80 \mathrm{E}+02$ & $7.29 E+01$ & $E-01$ & 01 & 1.9 & 01 & $00 \mathrm{E}+00$ & 00 & $E+00$ & $0.00 \mathrm{E}+00$ & +00 & $0.00 \mathrm{E}+00$ \\
\hline 4.90 & & & & & & +00 & & & +00 & & +00 \\
\hline $5.00 \mathrm{E}+02$ & +01 & $-1.45 \mathrm{E}-01$ & & 1.9 & $E-01$ & $0.00 \mathrm{E}+00$ & .00 & $0.00 \mathrm{E}+00$ & $0.00 \mathrm{E}+00$ & $2.99 \mathrm{E}+00$ & $0.00 \mathrm{E}+00$ \\
\hline $5.10 \mathrm{E}+02$ & +01 & $-1.40 \mathrm{E}-01$ & +01 & 1.93 & $E-01$ & $0.00 \mathrm{E}+00$ & & $\mathrm{E}+00$ & $0.00 \mathrm{E}+00$ & $3.00 \mathrm{E}+00$ & $E+00$ \\
\hline $5.20 \mathrm{E}+02$ & & $-1.36 \mathrm{E}-01$ & & & & $.00 \mathrm{E}+00$ & & $0.00 \mathrm{E}+00$ & $0.00 \mathrm{E}+00$ & $3.00 \mathrm{E}+00$ & $0.00 \mathrm{E}+00$ \\
\hline $5.30 \mathrm{E}+02$ & $7.26 \mathrm{E}+01$ & $-1.33 \mathrm{E}-01$ & $7.70 E+01$ & $1.93 E+01$ & $2 \mathrm{E}-01$ & $0.00 \mathrm{E}+00$ & $00 \mathrm{E}+00$ & $0.00 \mathrm{E}+00$ & $0.00 \mathrm{E}+00$ & $3.01 E+00$ & $0.00 \mathrm{E}+00$ \\
\hline & & & & & & & & $0.00 \mathrm{E}+00$ & $.00 \mathrm{E}+00$ & & $0.00 \mathrm{E}+00$ \\
\hline $5.50 \mathrm{E}+02$ & $7.25 \mathrm{E}+01$ & $-1.26 \mathrm{E}-01$ & $7.70 \mathrm{E}+01$ & $1.93 \mathrm{E}+01$ & $9 \mathrm{E}-01$ & $0.00 \mathrm{E}+00$ & $0.00 \mathrm{E}+00$ & $0.00 \mathrm{E}+00$ & $0.00 \mathrm{E}+00$ & $3.02 E+00$ & $0.00 \mathrm{E}+00$ \\
\hline $5.60 \mathrm{E}$ & & $-1.23 \mathrm{E}$ & & $1.93 \mathrm{E}$ & $83 \mathrm{E}-01$ & -00 & & -00 & +00 & 00 & $00 \mathrm{E}+00$ \\
\hline $5.70 \mathrm{E}+0$ & $7.24 \mathrm{E}+01$ & $-1.21 \mathrm{E}-$ & $1.10 \mathrm{E}$ & $1.92 \mathrm{E}+01$ & 38E-01 & $0.00 \mathrm{E}+00$ & $0.00 \mathrm{E}+00$ & $0.00 \mathrm{E}+00$ & $0.00 \mathrm{E}+00$ & 00 & $0.00 \mathrm{E}+00$ \\
\hline 5.80 & & -1.15 & & & & & & +00 & +00 & & +00 \\
\hline $5.90 \mathrm{E}+02$ & $7.25 \mathrm{E}+01$ & $-1.18 \mathrm{E}-01$ & $7.70 \mathrm{E}+01$ & $1.92 \mathrm{E}+01$ & $6.97 \mathrm{E}-01$ & $0.00 \mathrm{E}+00$ & $0.00 \mathrm{E}+00$ & $0.00 \mathrm{E}+00$ & $0.00 \mathrm{E}+00$ & $3.05 E+00$ & $0.00 \mathrm{E}+00$ \\
\hline & & & & & & & & & & & \\
\hline
\end{tabular}


WSRC-TR-2001-00405

\begin{tabular}{|c|c|c|c|c|c|c|c|c|c|c|c|}
\hline TIME & $\mathrm{HCl} \mathrm{c} \mathrm{(1)}$ & $\mathrm{HClu}$ & (1) & $\mathrm{HCl}$ & Lower N2 (1) & Lower O2 (1) & $\begin{array}{c}\text { Lower CO2 } \\
\text { (1) } \\
\end{array}$ & Lower CO (1) & \begin{tabular}{|c|} 
Lower HCN \\
$(1)$ \\
\end{tabular} & $\begin{array}{c}\text { Lower HCL } \\
(1)\end{array}$ & \begin{tabular}{|c|} 
Lower TUHC \\
(1)
\end{tabular} \\
\hline $0.00 E+00$ & $0.00 \mathrm{E}+00$ & $0.00 \mathrm{E}+00$ & $0.00 \mathrm{E}+00$ & $0.00 \mathrm{E}+00$ & $7.77 \mathrm{E}+01$ & $2.05 \mathrm{E}+01$ & $0.00 \mathrm{E}+00$ & $0.00 \mathrm{E}+00$ & $0.00 \mathrm{E}+00$ & $0.00 \mathrm{E}+00$ & $0.00 \mathrm{E}+00$ \\
\hline $1.00 \mathrm{E}+01$ & $0.00 \mathrm{E}+00$ & $.00 \mathrm{E}+00$ & $0.00 \mathrm{E}+00$ & $0.00 \mathrm{E}+00$ & $7.77 \mathrm{E}+01$ & $2.05 \mathrm{E}+01$ & $0.00 \mathrm{E}+00$ & $0.00 \mathrm{E}+00$ & $0.00 \mathrm{E}+00$ & $0.00 \mathrm{E}+00$ & $0.00 \mathrm{E}+00$ \\
\hline $2.00 \mathrm{E}+01$ & $0.00 \mathrm{E}+00$ & $0 \mathrm{E}+00$ & $.00 \mathrm{E}+00$ & $0.00 \mathrm{E}+00$ & $7.77 \mathrm{E}+01$ & $2.05 \mathrm{E}+01$ & $0.00 \mathrm{E}+00$ & $0.00 \mathrm{E}+00$ & $0.00 \mathrm{E}+00$ & $0.00 \mathrm{E}+00$ & $0.00 \mathrm{E}+00$ \\
\hline $3.00 \mathrm{E}+01$ & $0.00 \mathrm{E}+00$ & $.00 \mathrm{E}+00$ & $0.00 \mathrm{E}+00$ & $0.00 \mathrm{E}+00$ & $7.77 \mathrm{E}+01$ & $2.05 \mathrm{E}+01$ & $0.00 \mathrm{E}+00$ & $0.00 \mathrm{E}+00$ & $0.00 \mathrm{E}+00$ & $0.00 \mathrm{E}+00$ & $0.00 \mathrm{E}+00$ \\
\hline $4.00 \mathrm{E}+01$ & $0.00 \mathrm{E}+00$ & $0.00 \mathrm{E}+00$ & $0.00 \mathrm{E}+00$ & $0.00 \mathrm{E}+00$ & $7.77 E+01$ & $2.05 E+01$ & $0.00 E+00$ & $0.00 \mathrm{E}+00$ & $0.00 \mathrm{E}+00$ & $0.00 \mathrm{E}+00$ & $0.00 \mathrm{E}+00$ \\
\hline $5.00 \mathrm{E}+01$ & $0.00 \mathrm{E}+00$ & $.00 \mathrm{E}+00$ & $0.00 \mathrm{E}+00$ & $0.00 \mathrm{E}+00$ & $7.77 E+01$ & $2.05 E+01$ & $0.00 \mathrm{E}+00$ & $.00 \mathrm{E}+00$ & $0.00 \mathrm{E}+00$ & & $0.00 \mathrm{E}+00$ \\
\hline $6.00 \mathrm{E}+01$ & $0.00 \mathrm{E}+00$ & $0.00 \mathrm{E}+00$ & $0.00 \mathrm{E}+00$ & $0.00 \mathrm{E}+00$ & $7.77 \mathrm{E}+01$ & $2.05 \mathrm{E}+01$ & $0.00 \mathrm{E}+00$ & $.00 \mathrm{E}+00$ & $0.00 \mathrm{E}+00$ & $.00 \mathrm{E}+00$ & $.00 \mathrm{E}+00$ \\
\hline $7.00 E+01$ & $0.00 \mathrm{E}+00$ & $0.00 \mathrm{E}+00$ & $0.00 \mathrm{E}+00$ & $0.00 \mathrm{E}+00$ & $7.77 \mathrm{E}+01$ & $2.05 \mathrm{E}+01$ & $0.00 \mathrm{E}+00$ & $.00 \mathrm{E}+00$ & $0.00 \mathrm{E}+00$ & $.00 \mathrm{E}+00$ & $.00 \mathrm{E}+00$ \\
\hline $8.00 \mathrm{E}+01$ & $0.00 \mathrm{E}+00$ & $0.00 \mathrm{E}+00$ & $0.00 \mathrm{E}+00$ & $0.00 \mathrm{E}+00$ & $7.77 \mathrm{E}+01$ & $2.05 \mathrm{E}+01$ & $0.00 \mathrm{E}+00$ & $0.00 \mathrm{E}+00$ & $0.00 \mathrm{E}+00$ & $.00 \mathrm{E}+00$ & $.00 \mathrm{E}+00$ \\
\hline $9.00 \mathrm{E}+01$ & $0.00 \mathrm{E}+00$ & $0.00 \mathrm{E}+00$ & $0.00 \mathrm{E}+00$ & $0.00 \mathrm{E}+00$ & $7.77 \mathrm{E}+01$ & $2.05 \mathrm{E}+01$ & $0.00 \mathrm{E}+00$ & $0.00 \mathrm{E}+00$ & $0.00 \mathrm{E}+00$ & $0.00 \mathrm{E}+00$ & $0.00 \mathrm{E}+00$ \\
\hline $1.00 \mathrm{E}+02$ & $0.00 \mathrm{E}+00$ & $0.00 \mathrm{E}+00$ & $0.00 \mathrm{E}+00$ & $0.00 \mathrm{E}+00$ & $7.77 \mathrm{E}+01$ & $2.05 \mathrm{E}+01$ & $0.00 \mathrm{E}+00$ & $0.00 \mathrm{E}+00$ & $0.00 \mathrm{E}+00$ & $.00 \mathrm{E}+00$ & $0.00 \mathrm{E}+00$ \\
\hline $1.10 \mathrm{E}+02$ & $0.00 \mathrm{E}+00$ & $0.00 \mathrm{E}+00$ & $00 \mathrm{E}+00$ & $0.00 \mathrm{E}+00$ & $7.77 \mathrm{E}+01$ & $2.05 \mathrm{E}+01$ & $0.00 \mathrm{E}+00$ & $00 \mathrm{E}+00$ & $0.00 \mathrm{E}+00$ & & $00 \mathrm{E}+00$ \\
\hline $1.20 \mathrm{E}+02$ & $0.00 \mathrm{E}+00$ & $0.00 \mathrm{E}+00$ & $0.00 \mathrm{E}+00$ & $0.00 \mathrm{E}+00$ & $7.77 \mathrm{E}+01$ & $2.05 \mathrm{E}+01$ & $0.00 \mathrm{E}+00$ & $0.00 \mathrm{E}+00$ & $0.00 \mathrm{E}+00$ & $0.00 \mathrm{E}+00$ & $0.00 \mathrm{E}+00$ \\
\hline $1.30 \mathrm{E}+02$ & $0.00 \mathrm{E}+00$ & $0.00 \mathrm{E}+00$ & $0.00 \mathrm{E}+00$ & $0.00 \mathrm{E}+00$ & $7.77 \mathrm{E}+01$ & $2.05 \mathrm{E}+01$ & $00 \mathrm{E}+00$ & $0.00 \mathrm{E}+00$ & $00 \mathrm{E}+00$ & +00 & $0 \mathrm{E}+00$ \\
\hline $1.40 \mathrm{E}+02$ & $0.00 \mathrm{E}+00$ & $0.00 \mathrm{E}+00$ & $0.00 \mathrm{E}+00$ & $0.00 \mathrm{E}+00$ & $7.77 \mathrm{E}+01$ & $2.05 \mathrm{E}+01$ & $0.00 \mathrm{E}+00$ & $0.00 \mathrm{E}+00$ & $0.00 \mathrm{E}+00$ & $0.00 \mathrm{E}+00$ & $0.00 \mathrm{E}+00$ \\
\hline $1.50 \mathrm{E}+02$ & $0.00 \mathrm{E}+00$ & $0.00 \mathrm{E}+00$ & $0.00 \mathrm{E}+00$ & $0.00 \mathrm{E}+00$ & $7.77 \mathrm{E}+01$ & $2.05 \mathrm{E}+01$ & $0.00 \mathrm{E}+00$ & $0.00 \mathrm{E}+00$ & $0.00 \mathrm{E}+00$ & $0.00 \mathrm{E}+00$ & $0.00 \mathrm{E}+00$ \\
\hline $1.60 \mathrm{E}+02$ & $0.00 \mathrm{E}+00$ & $0.00 \mathrm{E}+00$ & $0.00 \mathrm{E}+00$ & $0.00 \mathrm{E}+00$ & $7.77 \mathrm{E}+01$ & $2.05 \mathrm{E}+01$ & $0.00 \mathrm{E}+00$ & $\mathrm{E}+00$ & $0.00 \mathrm{E}+00$ & & $.00 \mathrm{E}+00$ \\
\hline $1.70 \mathrm{E}+02$ & $0.00 \mathrm{E}+00$ & $0.00 \mathrm{E}+00$ & $0.00 \mathrm{E}+00$ & $0.00 \mathrm{E}+00$ & $7.77 \mathrm{E}+01$ & $2.05 \mathrm{E}+01$ & $0.00 \mathrm{E}+00$ & $0.00 \mathrm{E}+00$ & $0.00 \mathrm{E}+00$ & $0.00 \mathrm{E}+00$ & $0.00 \mathrm{E}+00$ \\
\hline $1.80 \mathrm{E}+02$ & $0.00 \mathrm{E}+00$ & & $0.00 \mathrm{E}+00$ & $0.00 \mathrm{E}+00$ & $7.77 \mathrm{E}+01$ & $2.05 \mathrm{E}+01$ & $0.00 \mathrm{E}+00$ & $0.00 \mathrm{E}+00$ & $0.00 \mathrm{E}+00$ & & $0.00 \mathrm{E}+00$ \\
\hline $1.90 \mathrm{E}+02$ & $0.00 \mathrm{E}+00$ & $0.00 \mathrm{E}+00$ & $0.00 \mathrm{E}+00$ & $0.00 \mathrm{E}+00$ & $7.77 \mathrm{E}+01$ & $2.05 \mathrm{E}+01$ & $0.00 \mathrm{E}+00$ & $.00 \mathrm{E}+00$ & $0.00 \mathrm{E}+00$ & $0.00 \mathrm{E}+00$ & $0.00 \mathrm{E}+00$ \\
\hline $2.00 \mathrm{E}+02$ & $0.00 \mathrm{E}+00$ & & $0.00 \mathrm{E}+00$ & $0.00 \mathrm{E}+00$ & $7.77 \mathrm{E}+01$ & $2.05 \mathrm{E}+01$ & & $\mathrm{E}+00$ & & & $0 \mathrm{E}+00$ \\
\hline $2.10 \mathrm{E}+02$ & $0.00 \mathrm{E}+00$ & +00 & $0.00 \mathrm{E}+00$ & $0.00 \mathrm{E}+00$ & $7.78 \mathrm{E}+01$ & $2.05 E+01$ & $00 \mathrm{E}+00$ & $E+00$ & $0.00 \mathrm{E}+00$ & & $0 \mathrm{E}+00$ \\
\hline $2.20 \mathrm{E}+02$ & $0.00 \mathrm{E}+00$ & & $0.00 \mathrm{E}+00$ & $0.00 \mathrm{E}+00$ & & $.05 \mathrm{E}+01$ & & & & & $\mathrm{DE}+00$ \\
\hline $2.30 \mathrm{E}+02$ & $0.00 \mathrm{E}+00$ & & $0.00 \mathrm{E}+00$ & $0.00 \mathrm{E}+00$ & $7.78 \mathrm{E}+01$ & $2.05 \mathrm{E}+01$ & +00 & +00 & $0.00 \mathrm{E}+00$ & & $\mathrm{E}+00$ \\
\hline $2.40 \mathrm{E}+02$ & $0.00 \mathrm{E}+00$ & +00 & $0.00 \mathrm{E}+00$ & $0.00 \mathrm{E}+00$ & $7.78 \mathrm{E}+01$ & $2.05 \mathrm{E}+01$ & $00 \mathrm{E}+00$ & $\mathrm{E}+00$ & $0.00 \mathrm{E}+00$ & & $0 \mathrm{E}+00$ \\
\hline $2.50 \mathrm{E}+02$ & $0.00 \mathrm{E}+00$ & & $0.00 \mathrm{E}+00$ & $0.00 \mathrm{E}+00$ & $7.78 \mathrm{E}+01$ & $2.05 \mathrm{E}+01$ & & & & & $E+00$ \\
\hline $2.60 \mathrm{E}+02$ & $0.00 \mathrm{E}+00$ & $0.00 \mathrm{E}+00$ & $0.00 \mathrm{E}+00$ & $0.00 \mathrm{E}+00$ & $7.78 \mathrm{E}+01$ & $2.05 \mathrm{E}+01$ & $0.00 \mathrm{E}+00$ & $0.00 \mathrm{E}+00$ & $0.00 \mathrm{E}+00$ & $0.00 \mathrm{E}+00$ & $0.00 \mathrm{E}+00$ \\
\hline $2.70 E+02$ & $0.00 \mathrm{E}+00$ & $0.00 \mathrm{E}+00$ & $0.00 \mathrm{E}+00$ & $0.00 \mathrm{E}+00$ & $7.78 \mathrm{E}+01$ & $2.05 \mathrm{E}+01$ & $00 \mathrm{E}+00$ & $00 \mathrm{E}+00$ & $0.00 \mathrm{E}+00$ & +00 & $\mathrm{DE}+00$ \\
\hline $2.80 \mathrm{E}+02$ & $0.00 \mathrm{E}+00$ & $00 \mathrm{E}+00$ & $0.00 \mathrm{E}+00$ & $0.00 \mathrm{E}+00$ & $7.78 \mathrm{E}+01$ & $2.05 \mathrm{E}+01$ & $00 \mathrm{E}+00$ & $0.00 \mathrm{E}+00$ & $0.00 \mathrm{E}+00$ & $E+00$ & $0.00 \mathrm{E}+00$ \\
\hline $2.90 \mathrm{E}+02$ & $0.00 \mathrm{E}+00$ & $0.00 \mathrm{E}+00$ & $0.00 \mathrm{E}+00$ & $0.00 \mathrm{E}+00$ & $7.78 \mathrm{E}+01$ & $2.05 \mathrm{E}+01$ & $00 \mathrm{E}+00$ & $00 \mathrm{E}+00$ & $00 \mathrm{E}+00$ & +00 & $0 \mathrm{E}+00$ \\
\hline $3.00 \mathrm{E}+02$ & $0.00 \mathrm{E}+00$ & +00 & $00 \mathrm{E}+00$ & $0.00 \mathrm{E}+00$ & $7.78 \mathrm{E}+01$ & $05 \mathrm{E}+01$ & 00 & $E+00$ & +00 & 00 & $\bar{E}+00$ \\
\hline $3.10 \mathrm{E}+02$ & $0.00 \mathrm{E}+00$ & & 00 & $0.00 \mathrm{E}+00$ & 01 & +01 & & +00 & & & $E+00$ \\
\hline $3.20 \mathrm{E}+02$ & $0.00 \mathrm{E}+00$ & & $0.00 \mathrm{E}+00$ & $0.00 \mathrm{E}+00$ & $7.78 \mathrm{E}+01$ & $2.05 \mathrm{E}+01$ & & +00 & $0.00 \mathrm{E}+00$ & & $E+00$ \\
\hline $3.30 \mathrm{E}+02$ & $0.00 \mathrm{E}+00$ & $\mathrm{E}+00$ & $0.00 \mathrm{E}+00$ & $0.00 \mathrm{E}+00$ & $7.78 E+01$ & $2.05 \mathrm{E}+01$ & $00 \mathrm{E}+00$ & $\mathrm{E}+00$ & $0.00 \mathrm{E}+00$ & $0.00 \mathrm{E}+00$ & $0 \mathrm{E}+00$ \\
\hline $3.40 \mathrm{E}+02$ & $0.00 \mathrm{E}+00$ & & $0.00 \mathrm{E}+00$ & $0.00 \mathrm{E}+00$ & $7.78 \mathrm{E}+01$ & & & $E+00$ & & & $E+00$ \\
\hline $3.50 \mathrm{E}+02$ & $0.00 \mathrm{E}+00$ & $0.00 \mathrm{E}+00$ & $0.00 \mathrm{E}+00$ & $0.00 \mathrm{E}+00$ & $7.78 \mathrm{E}+01$ & $2.05 \mathrm{E}+01$ & $00 \mathrm{E}+00$ & $0.00 \mathrm{E}+00$ & $0.00 \mathrm{E}+00$ & $0.00 \mathrm{E}+00$ & $0.00 \mathrm{E}+00$ \\
\hline & $0.00 \mathrm{E}+00$ & & $0.00 \mathrm{E}+00$ & $0.00 \mathrm{E}+00$ & & & & & & & \\
\hline $3.70 \mathrm{E}+02$ & $0.00 \mathrm{E}+00$ & 00 & $00 \mathrm{E}+00$ & $0.00 \mathrm{E}+00$ & $7.78 \mathrm{E}+01$ & $05 \mathrm{E}+01$ & 100 & $E+00$ & $0.00 \mathrm{E}+00$ & +00 & $0 \mathrm{E}+00$ \\
\hline & 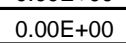 & & $00 \mathrm{E}+00$ & $0.00 \mathrm{E}+00$ & & & & & & & \\
\hline $3.90 \mathrm{E}+02$ & $0.00 \mathrm{E}+00$ & & $00 \mathrm{E}$ & $0.00 \mathrm{E}+00$ & 01 & 01 & & +00 & +00 & & $\mathrm{E}+00$ \\
\hline 4.00 & $0.00 \mathrm{E}+00$ & & $00 \mathrm{E}+00$ & $0.00 \mathrm{E}+00$ & & $2.05 \mathrm{E}+01$ & & & & & $E+00$ \\
\hline $4.10 \mathrm{E}+02$ & $0.00 \mathrm{E}+00$ & & $0.00 \mathrm{E}+00$ & $0.00 \mathrm{E}+00$ & $779 \mathrm{~F}+01$ & $2.05 \mathrm{E}+01$ & .00 & $E+00$ & +00 & & $E+00$ \\
\hline $4.20 \mathrm{E}+02$ & $0.00 \mathrm{E}+00$ & $E+00$ & $00 \mathrm{E}+00$ & $0.00 \mathrm{E}+00$ & $7.79 E+01$ & $2.05 \mathrm{E}+01$ & $0.00 \mathrm{E}+00$ & $00 E+00$ & $0.00 \mathrm{E}+00$ & +00 & $E+00$ \\
\hline $4.30 \mathrm{E}+\mathrm{C}$ & $0.00 \mathrm{E}+00$ & & 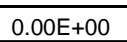 & $0.00 \mathrm{E}+00$ & $77-$ & & & & & & \\
\hline $4.40 \mathrm{E}+02$ & $0.00 \mathrm{E}+00$ & $0.00 \mathrm{E}+00$ & $0.00 \mathrm{E}+00$ & $0.00 \mathrm{E}+00$ & $7.79 \mathrm{E}+01$ & $2.05 \mathrm{E}+01$ & $00 \mathrm{E}+00$ & $0.00 \mathrm{E}+00$ & $0.00 \mathrm{E}+00$ & $0.00 \mathrm{E}+00$ & $0.00 \mathrm{E}+00$ \\
\hline & 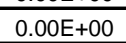 & & & & & & & & & & \\
\hline $4.60 \mathrm{E}+02$ & $0.00 \mathrm{E}+00$ & $0.00 \mathrm{E}+00$ & $0.00 \mathrm{E}+00$ & $0.00 \mathrm{E}+00$ & $7.79 \mathrm{E}+01$ & $05 \mathrm{E}+01$ & $00 \mathrm{E}+00$ & $.00 \mathrm{E}+00$ & $0.00 \mathrm{E}+00$ & $.00 \mathrm{E}+00$ & $0.00 \mathrm{E}+00$ \\
\hline & $0.00 \mathrm{E}+00$ & & & & & & & & & & \\
\hline $4.80 \mathrm{E}+02$ & $0.00 \mathrm{E}+00$ & 0. & $0.00 \mathrm{E}+00$ & $0.00 \mathrm{E}+00$ & $7.80 \mathrm{E}+01$ & $05 \mathrm{E}+01$ & +00 & $E+00$ & $.00 \mathrm{E}+00$ & +00 & $0.00 \mathrm{E}+00$ \\
\hline & $0.00 \mathrm{E}+00$ & & 00 & & & & & & & & +00 \\
\hline $5.00 \mathrm{E}+02$ & $0.00 \mathrm{E}+00$ & 0. & $0.00 \mathrm{E}+00$ & $0.00 \mathrm{E}+00$ & $7.80 \mathrm{E}+01$ & $2.05 \mathrm{E}+01$ & $0 \mathrm{E}+00$ & $00 \mathrm{E}+00$ & $0.00 \mathrm{E}+00$ & $0.00 \mathrm{E}+00$ & $0.00 \mathrm{E}+00$ \\
\hline $5.10 \mathrm{E}+02$ & $0.00 \mathrm{E}+00$ & $0.00 \mathrm{E}+00$ & $0.00 \mathrm{E}+00$ & $0.00 \mathrm{E}+00$ & $7.80 \mathrm{E}+01$ & $2.05 \mathrm{E}+01$ & $E+00$ & $E+00$ & $0.00 \mathrm{E}+00$ & $0.00 \mathrm{E}+00$ & $E+00$ \\
\hline $5.20 \mathrm{E}+02$ & $0.00 \mathrm{E}+00$ & . & $000=0$ & $0.00 \mathrm{E}+00$ & $780=0$ & $05 \mathrm{~F}+11$ & $0.00 \mathrm{E}+00$ & $0.00 \mathrm{E}+00$ & $0.00 \mathrm{E}+00$ & $0.00 \mathrm{E}+00$ & $0.00 \mathrm{E}+00$ \\
\hline $5.30 \mathrm{E}+02$ & $0.00 \mathrm{E}+00$ & $0.00 \mathrm{E}+00$ & $0.00 \mathrm{E}+00$ & $0.00 \mathrm{E}+00$ & $7.80 \mathrm{E}+01$ & $.05 \mathrm{E}+01$ & $00 \mathrm{E}+00$ & $0.00 \mathrm{E}+00$ & $0.00 \mathrm{E}+00$ & $0.00 \mathrm{E}+00$ & $0.00 \mathrm{E}+00$ \\
\hline & $x=$ & & & & & & & $0.00 \mathrm{E}+00$ & & & $0.00 \mathrm{E}+00$ \\
\hline $5.50 \mathrm{E}+02$ & $0.00 \mathrm{E}+00$ & $0.00 \mathrm{E}+00$ & $0.00 \mathrm{E}+00$ & $0.00 \mathrm{E}+00$ & $7.80 \mathrm{E}+01$ & $2.05 E+01$ & $00 \mathrm{E}+00$ & $00 \mathrm{E}+00$ & $.00 \mathrm{E}+00$ & $0.00 E+00$ & $00 \mathrm{E}+00$ \\
\hline $5.60 \mathrm{E}$ & $0.00 \mathrm{E}+0$ & & - & $0.00 \mathrm{E}$ & & & - & -00 & - & & $00 \mathrm{E}+00$ \\
\hline $5.70 \mathrm{E}+\mathrm{C}$ & $0.00 \mathrm{E}+00$ & $0.00 \mathrm{E}+$ & $00 \mathrm{E}-$ & $0.00 \mathrm{E}+00$ & $7.81 \mathrm{E}+01$ & $2.05 \mathrm{E}+01$ & $0.00 \mathrm{E}+00$ & $0.00 \mathrm{E}+00$ & 00 & .00 & $0.00 \mathrm{E}+00$ \\
\hline 5.80 & $0.00 \mathrm{E}+00$ & & & 0.0 & & & & +00 & & & +00 \\
\hline $5.90 \mathrm{E}+02$ & $0.00 \mathrm{E}+00$ & $0.00 \mathrm{E}+00$ & $0.00 \mathrm{E}+00$ & $0.00 \mathrm{E}+00$ & $7.81 \mathrm{E}+01$ & $2.05 E+01$ & $0.00 \mathrm{E}+00$ & $0.00 \mathrm{E}+00$ & $0.00 \mathrm{E}+00$ & $0.00 \mathrm{E}+00$ & -00 \\
\hline & & & & & & & & & +00 & ++0 & 00 \\
\hline
\end{tabular}


WSRC-TR-2001-00405

\begin{tabular}{|c|c|c|c|c|c|c|c|c|c|c|}
\hline TIME & $\begin{array}{c}\text { Lower } \mathrm{H} 2 \mathrm{O} \\
\text { (1) }\end{array}$ & Lower OD (1) & $\mathrm{HCl} \mathrm{c}(1)$ & $\mathrm{HCl}$ uw (1) & $\mathrm{HCl} \operatorname{lw}(1)$ & $\mathrm{HCl} f(1)$ & \begin{tabular}{|l|} 
Upper Inflow \\
1-Outside (1)
\end{tabular} & $\begin{array}{c}\text { Upper } \\
\text { Outflow 1- } \\
\text { Outside (1) }\end{array}$ & $\begin{array}{l}\text { Lower Inflow } \\
\text { 1-Outside (1) }\end{array}$ & \begin{tabular}{|c|} 
Lower \\
Outflow 1- \\
Outside (1)
\end{tabular} \\
\hline $0.00 \mathrm{E}+00$ & $1.75 \mathrm{E}+00$ & $0.00 \mathrm{E}+00$ & $0.00 \mathrm{E}+00$ & $0.00 \mathrm{E}+00$ & $0.00 \mathrm{E}+00$ & $0.00 \mathrm{E}+00$ & $0.00 \mathrm{E}+00$ & $0.00 \mathrm{E}+00$ & $4.00 \mathrm{E}-18$ & $0.00 \mathrm{E}+00$ \\
\hline $1.00 \mathrm{E}+01$ & $1.75 \mathrm{E}+00$ & $0.00 \mathrm{E}+00$ & $0.00 \mathrm{E}+00$ & $0.00 \mathrm{E}+00$ & $0.00 \mathrm{E}+00$ & $0.00 \mathrm{E}+00$ & $0.00 \mathrm{E}+00$ & $0.00 \mathrm{E}+00$ & $0.00 \mathrm{E}+00$ & $5.52 \mathrm{E}-02$ \\
\hline $2.00 \mathrm{E}+01$ & $1.75 \mathrm{E}+00$ & $0.00 \mathrm{E}+00$ & $0.00 \mathrm{E}+00$ & $0.00 \mathrm{E}+00$ & $0.00 \mathrm{E}+00$ & $0.00 \mathrm{E}+00$ & $0.00 \mathrm{E}+00$ & $0.00 \mathrm{E}+00$ & $.00 \mathrm{E}+00$ & $1.11 \mathrm{E}-01$ \\
\hline $3.00 \mathrm{E}+01$ & $1.75 \mathrm{E}+00$ & $0.00 \mathrm{E}+00$ & $0.00 \mathrm{E}+00$ & $0.00 \mathrm{E}+00$ & $0.00 \mathrm{E}+00$ & $0.00 \mathrm{E}+00$ & $0.00 \mathrm{E}+00$ & $0.00 \mathrm{E}+00$ & $.00 \mathrm{E}+00$ & $1.65 \mathrm{E}-01$ \\
\hline $4.00 \mathrm{E}+01$ & $1.75 \mathrm{E}+00$ & $0.00 \mathrm{E}+00$ & $0.00 \mathrm{E}+00$ & $0.00 \mathrm{E}+00$ & $0.00 \mathrm{E}+00$ & $0.00 \mathrm{E}+00$ & $0.00 \mathrm{E}+00$ & $0.00 \mathrm{E}+00$ & $.00 \mathrm{E}+00$ & $2.18 \mathrm{E}-01$ \\
\hline $5.00 \mathrm{E}+01$ & $1.75 \mathrm{E}+00$ & $0.00 \mathrm{E}+00$ & $.00 \mathrm{E}+00$ & $0.00 \mathrm{E}+00$ & $0.00 \mathrm{E}+00$ & $0.00 \mathrm{E}+00$ & $0.00 \mathrm{E}+00$ & $0.00 \mathrm{E}+00$ & $.00 \mathrm{E}+00$ & $2.70 \mathrm{E}-01$ \\
\hline $6.00 \mathrm{E}+01$ & $1.75 \mathrm{E}+00$ & $0.00 \mathrm{E}+00$ & $0.00 \mathrm{E}+00$ & $0.00 \mathrm{E}+00$ & $0.00 \mathrm{E}+00$ & $0.00 \mathrm{E}+00$ & $0.00 \mathrm{E}+00$ & $0.00 \mathrm{E}+00$ & $0.00 \mathrm{E}+00$ & $3.22 \mathrm{E}-01$ \\
\hline $7.00 \mathrm{E}+01$ & $1.75 \mathrm{E}+00$ & $0.00 \mathrm{E}+00$ & $0.00 \mathrm{E}+00$ & $0.00 \mathrm{E}+00$ & $0.00 \mathrm{E}+00$ & $0.00 \mathrm{E}+00$ & $0.00 \mathrm{E}+00$ & $0.00 \mathrm{E}+00$ & $0.00 \mathrm{E}+00$ & $3.68 \mathrm{E}-01$ \\
\hline $8.00 \mathrm{E}+01$ & $1.75 \mathrm{E}+00$ & $0.00 \mathrm{E}+00$ & $0.00 \mathrm{E}+00$ & $0.00 \mathrm{E}+00$ & $0.00 \mathrm{E}+00$ & $0.00 \mathrm{E}+00$ & $0.00 \mathrm{E}+00$ & $0.00 \mathrm{E}+00$ & $0.00 \mathrm{E}+00$ & 4.09E-01 \\
\hline $9.00 \mathrm{E}+01$ & $1.75 \mathrm{E}+00$ & $0.00 \mathrm{E}+00$ & $0.00 \mathrm{E}+00$ & $0.00 \mathrm{E}+00$ & $0.00 \mathrm{E}+00$ & $0.00 \mathrm{E}+00$ & $0.00 \mathrm{E}+00$ & $0.00 \mathrm{E}+00$ & $0.00 \mathrm{E}+00$ & 4.47E-01 \\
\hline $1.00 \mathrm{E}+02$ & $1.75 \mathrm{E}+00$ & $0.00 \mathrm{E}+00$ & $0.00 \mathrm{E}+00$ & $0.00 \mathrm{E}+00$ & $0.00 \mathrm{E}+00$ & $0.00 \mathrm{E}+00$ & $0.00 \mathrm{E}+00$ & $0.00 \mathrm{E}+00$ & $0.00 \mathrm{E}+00$ & 4.83E-01 \\
\hline $1.10 \mathrm{E}+02$ & $1.75 \mathrm{E}+00$ & $0.00 \mathrm{E}+00$ & $0.00 \mathrm{E}+00$ & $0.00 \mathrm{E}+00$ & $0.00 \mathrm{E}+00$ & $0.00 \mathrm{E}+00$ & $0.00 \mathrm{E}+00$ & $0.00 \mathrm{E}+00$ & $0.00 \mathrm{E}+00$ & $5.17 \mathrm{E}-01$ \\
\hline $1.20 \mathrm{E}+02$ & $1.75 \mathrm{E}+00$ & $0.00 \mathrm{E}+00$ & $0.00 \mathrm{E}+00$ & $0.00 \mathrm{E}+00$ & $0.00 \mathrm{E}+00$ & $0.00 \mathrm{E}+00$ & & $0.00 \mathrm{E}+00$ & $E+00$ & $E-01$ \\
\hline $1.30 \mathrm{E}+02$ & $1.75 \mathrm{E}+00$ & $0.00 \mathrm{E}+00$ & $0.00 \mathrm{E}+00$ & $0.00 \mathrm{E}+00$ & $0.00 \mathrm{E}+00$ & $0.00 \mathrm{E}+00$ & $0.00 \mathrm{E}+00$ & $0.00 \mathrm{E}+00$ & $.00 \mathrm{E}+00$ & $5.74 \mathrm{E}-01$ \\
\hline $1.40 \mathrm{E}+02$ & $1.75 \mathrm{E}+00$ & $0.00 \mathrm{E}+00$ & $0.00 \mathrm{E}+00$ & $0.00 \mathrm{E}+00$ & $0.00 \mathrm{E}+00$ & $0.00 \mathrm{E}+00$ & $0.00 \mathrm{E}+00$ & $0.00 \mathrm{E}+00$ & $0.00 \mathrm{E}+00$ & $5.85 \mathrm{E}-01$ \\
\hline $1.50 \mathrm{E}+02$ & $1.75 \mathrm{E}+00$ & $0.00 \mathrm{E}+00$ & $0.00 \mathrm{E}+00$ & $0.00 \mathrm{E}+00$ & $0.00 \mathrm{E}+00$ & $0.00 \mathrm{E}+00$ & $0.00 \mathrm{E}+00$ & $0.00 \mathrm{E}+00$ & $0.00 \mathrm{E}+00$ & $5.86 \mathrm{E}-01$ \\
\hline $1.60 \mathrm{E}+02$ & $1.75 \mathrm{E}+00$ & $0.00 \mathrm{E}+00$ & $0.00 \mathrm{E}+00$ & $0.00 \mathrm{E}+00$ & $0.00 \mathrm{E}+00$ & $0.00 \mathrm{E}+00$ & $0.00 \mathrm{E}+00$ & $0.00 \mathrm{E}+00$ & $0.00 \mathrm{E}+00$ & $5.82 \mathrm{E}-01$ \\
\hline $1.70 \mathrm{E}+02$ & $1.75 \mathrm{E}+00$ & $0.00 \mathrm{E}+00$ & $0.00 \mathrm{E}+00$ & $0.00 \mathrm{E}+00$ & $0.00 \mathrm{E}+00$ & $0.00 \mathrm{E}+00$ & $0.00 \mathrm{E}+00$ & $0.00 \mathrm{E}+00$ & $0.00 \mathrm{E}+00$ & $5.72 \mathrm{E}-01$ \\
\hline $1.80 \mathrm{E}+02$ & $1.75 \mathrm{E}+00$ & $0.00 \mathrm{E}+00$ & $0.00 \mathrm{E}+00$ & $0.00 \mathrm{E}+00$ & $0.00 \mathrm{E}+00$ & $0.00 \mathrm{E}+00$ & $0.00 \mathrm{E}+00$ & $0.00 \mathrm{E}+00$ & $0.00 \mathrm{E}+00$ & $5.60 \mathrm{E}-01$ \\
\hline $1.90 \mathrm{E}+02$ & $1.75 \mathrm{E}+00$ & $0.00 \mathrm{E}+00$ & $0.00 \mathrm{E}+00$ & $0.00 \mathrm{E}+00$ & $0.00 \mathrm{E}+00$ & $0.00 \mathrm{E}+00$ & $0.00 \mathrm{E}+00$ & $0.00 \mathrm{E}+00$ & $0.00 \mathrm{E}+00$ & $5.38 \mathrm{E}-01$ \\
\hline $2.00 \mathrm{E}+02$ & $1.75 \mathrm{E}+00$ & $0.00 \mathrm{E}+00$ & $0.00 \mathrm{E}+00$ & $0.00 \mathrm{E}+00$ & $0.00 \mathrm{E}+00$ & $0.00 \mathrm{E}+00$ & $0.00 \mathrm{E}+00$ & $0.00 \mathrm{E}+00$ & $0.00 \mathrm{E}+00$ & $5.03 \mathrm{E}-01$ \\
\hline $2.10 \mathrm{E}+02$ & $1.75 \mathrm{E}+00$ & $0.00 \mathrm{E}+00$ & $0.00 \mathrm{E}+00$ & $0.00 \mathrm{E}+00$ & $0.00 \mathrm{E}+00$ & $0.00 \mathrm{E}+00$ & $0.00 \mathrm{E}+00$ & $0.00 \mathrm{E}+00$ & $0.00 \mathrm{E}+00$ & $4.56 \mathrm{E}-01$ \\
\hline $2.20 \mathrm{E}+02$ & $1.75 \mathrm{E}+00$ & $0.00 \mathrm{E}+00$ & $0.00 \mathrm{E}+00$ & $0.00 \mathrm{E}+00$ & $0.00 \mathrm{E}+00$ & $0.00 \mathrm{E}+00$ & $0.00 \mathrm{E}+00$ & $0.00 \mathrm{E}+00$ & $.00 \mathrm{E}+00$ & $.00 \mathrm{E}-01$ \\
\hline $2.30 \mathrm{E}+02$ & $1.75 \mathrm{E}+00$ & $0.00 \mathrm{E}+00$ & $0.00 \mathrm{E}+00$ & $0.00 \mathrm{E}+00$ & $0.00 \mathrm{E}+00$ & $0.00 \mathrm{E}+00$ & $0.00 \mathrm{E}+00$ & $0.00 \mathrm{E}+00$ & $.00 \mathrm{E}+00$ & $36 \mathrm{E}-01$ \\
\hline $2.40 \mathrm{E}+02$ & $1.75 \mathrm{E}+00$ & $0.00 \mathrm{E}+00$ & $0.00 \mathrm{E}+00$ & $0.00 \mathrm{E}+00$ & $0.00 \mathrm{E}+00$ & $0.00 \mathrm{E}+00$ & $0.00 \mathrm{E}+00$ & $0.00 \mathrm{E}+00$ & $0.00 \mathrm{E}+00$ & $2.62 \mathrm{E}-01$ \\
\hline $2.50 \mathrm{E}+02$ & $1.75 \mathrm{E}+00$ & $0.00 \mathrm{E}+00$ & $0.00 \mathrm{E}+00$ & $0.00 \mathrm{E}+00$ & $0.00 \mathrm{E}+00$ & $0.00 \mathrm{E}+00$ & $0.00 \mathrm{E}+00$ & $0.00 \mathrm{E}+00$ & $0.00 \mathrm{E}+00$ & $1.91 \mathrm{E}-01$ \\
\hline $2.60 \mathrm{E}+02$ & $1.75 \mathrm{E}+00$ & $0.00 \mathrm{E}+00$ & $0.00 \mathrm{E}+00$ & $0.00 \mathrm{E}+00$ & $0.00 \mathrm{E}+00$ & $0.00 \mathrm{E}+00$ & $0.00 \mathrm{E}+00$ & $0.00 \mathrm{E}+00$ & $0.00 \mathrm{E}+00$ & $1.34 \mathrm{E}-01$ \\
\hline $2.70 \mathrm{E}+02$ & $1.75 \mathrm{E}+00$ & $0.00 \mathrm{E}+00$ & $0.00 \mathrm{E}+00$ & $0.00 \mathrm{E}+00$ & $0.00 \mathrm{E}+00$ & $0.00 \mathrm{E}+00$ & $0.00 \mathrm{E}+00$ & $0.00 \mathrm{E}+00$ & $0.00 \mathrm{E}+00$ & $9.22 \mathrm{E}-02$ \\
\hline $2.80 \mathrm{E}+02$ & $1.75 \mathrm{E}+00$ & $0.00 \mathrm{E}+00$ & $0.00 \mathrm{E}+00$ & $0.00 \mathrm{E}+00$ & $0.00 \mathrm{E}+00$ & $0.00 \mathrm{E}+00$ & $0.00 \mathrm{E}+00$ & $0.00 \mathrm{E}+00$ & $0.00 \mathrm{E}+00$ & $6.25 \mathrm{E}-02$ \\
\hline $2.90 \mathrm{E}+02$ & $1.75 \mathrm{E}+00$ & $0.00 \mathrm{E}+00$ & $0.00 \mathrm{E}+00$ & $0.00 \mathrm{E}+00$ & $0.00 \mathrm{E}+00$ & $0.00 \mathrm{E}+00$ & $0.00 \mathrm{E}+00$ & $0.00 \mathrm{E}+00$ & $0.00 \mathrm{E}+00$ & $.88 \mathrm{E}-02$ \\
\hline $3.00 \mathrm{E}+02$ & $1.75 \mathrm{E}+00$ & $0.00 \mathrm{E}+00$ & $0.00 \mathrm{E}+00$ & $0.00 \mathrm{E}+00$ & $0.00 \mathrm{E}+00$ & $0.00 \mathrm{E}+00$ & $0.00 \mathrm{E}+00$ & $0.00 \mathrm{E}+00$ & $0.00 \mathrm{E}+00$ & $1.72 \mathrm{E}-02$ \\
\hline $3.10 \mathrm{E}+02$ & $1.75 \mathrm{E}+00$ & $0.00 \mathrm{E}+00$ & $0.00 \mathrm{E}+00$ & $0.00 \mathrm{E}+00$ & $0.00 \mathrm{E}+00$ & $0.00 \mathrm{E}+00$ & $0.00 \mathrm{E}+00$ & $0.00 \mathrm{E}+00$ & $.51 \mathrm{E}-03$ & $0.00 \mathrm{E}+00$ \\
\hline $3.20 \mathrm{E}+02$ & $1.75 \mathrm{E}+00$ & $0.00 \mathrm{E}+00$ & $0.00 \mathrm{E}+00$ & $0.00 \mathrm{E}+00$ & $0.00 \mathrm{E}+00$ & $0.00 \mathrm{E}+00$ & $0.00 \mathrm{E}+00$ & $0.00 \mathrm{E}+00$ & $.81 \mathrm{E}-02$ & $0.00 \mathrm{E}+00$ \\
\hline $3.30 \mathrm{E}+02$ & $1.74 \mathrm{E}+00$ & $0.00 \mathrm{E}+00$ & $0.00 \mathrm{E}+00$ & $0.00 \mathrm{E}+00$ & $0.00 \mathrm{E}+00$ & $0.00 \mathrm{E}+00$ & $0.00 \mathrm{E}+00$ & $0.00 \mathrm{E}+00$ & $3.32 \mathrm{E}-02$ & $0 \mathrm{E}+00$ \\
\hline $3.40 \mathrm{E}+02$ & $1.73 \mathrm{E}+00$ & $0.00 \mathrm{E}+00$ & $0.00 \mathrm{E}+00$ & $0.00 \mathrm{E}+00$ & $0.00 \mathrm{E}+00$ & $0.00 \mathrm{E}+00$ & $0.00 \mathrm{E}+00$ & $0.00 \mathrm{E}+00$ & $4.78 \mathrm{E}-02$ & $E+00$ \\
\hline $3.50 \mathrm{E}+02$ & $1.72 \mathrm{E}+00$ & $0.00 \mathrm{E}+00$ & $0.00 \mathrm{E}+00$ & $0.00 \mathrm{E}+00$ & $0.00 \mathrm{E}+00$ & $0.00 \mathrm{E}+00$ & $0.00 \mathrm{E}+00$ & $0.00 \mathrm{E}+00$ & $6.20 \mathrm{E}-02$ & $0.00 \mathrm{E}+00$ \\
\hline $3.60 \mathrm{E}+02$ & $1.71 \mathrm{E}+00$ & $0.00 \mathrm{E}+00$ & $0.00 \mathrm{E}+00$ & $0.00 \mathrm{E}+00$ & $0.00 \mathrm{E}+00$ & $0.00 \mathrm{E}+00$ & $0.00 \mathrm{E}+00$ & $0.00 \mathrm{E}+00$ & $7.57 \mathrm{E}-02$ & $0.00 \mathrm{E}+00$ \\
\hline $3.70 \mathrm{E}+02$ & $1.70 \mathrm{E}+00$ & $0.00 \mathrm{E}+00$ & $0.00 \mathrm{E}+00$ & $0.00 \mathrm{E}+00$ & $0.00 \mathrm{E}+00$ & $0.00 \mathrm{E}+00$ & $0.00 \mathrm{E}+00$ & $0.00 \mathrm{E}+00$ & $7.85 \mathrm{E}-02$ & $0.00 \mathrm{E}+00$ \\
\hline $3.80 \mathrm{E}+02$ & $1.68 \mathrm{E}+00$ & $0.00 \mathrm{E}+00$ & $0.00 \mathrm{E}+00$ & $0.00 \mathrm{E}+00$ & $0.00 \mathrm{E}+00$ & $0.00 \mathrm{E}+00$ & $0.00 \mathrm{E}+00$ & $0.00 \mathrm{E}+00$ & $7.46 \mathrm{E}-02$ & $0.00 \mathrm{E}+00$ \\
\hline $3.90 \mathrm{E}+02$ & $1.67 \mathrm{E}+00$ & $0.00 \mathrm{E}+00$ & $0.00 \mathrm{E}+00$ & $0.00 \mathrm{E}+00$ & $0.00 \mathrm{E}+00$ & $0.00 \mathrm{E}+00$ & $0.00 \mathrm{E}+00$ & $0.00 \mathrm{E}+00$ & $7.00 \mathrm{E}-02$ & $0.00 \mathrm{E}+00$ \\
\hline $4.00 \mathrm{E}+02$ & $1.65 \mathrm{E}+00$ & $0.00 \mathrm{E}+00$ & $0.00 \mathrm{E}+00$ & $0.00 \mathrm{E}+00$ & $0.00 \mathrm{E}+00$ & $0.00 \mathrm{E}+00$ & $0.00 \mathrm{E}+00$ & $0.00 \mathrm{E}+00$ & $.55 \mathrm{E}-02$ & $0.00 \mathrm{E}+00$ \\
\hline $4.10 \mathrm{E}+02$ & $1.64 \mathrm{E}+00$ & $0.00 \mathrm{E}+00$ & $0.00 \mathrm{E}+00$ & $0.00 \mathrm{E}+00$ & $0.00 \mathrm{E}+00$ & $0.00 \mathrm{E}+00$ & $0.00 \mathrm{E}+00$ & $0.00 \mathrm{E}+00$ & $13 \mathrm{E}-02$ & $0.00 \mathrm{E}+00$ \\
\hline $4.20 \mathrm{E}+02$ & $1.63 \mathrm{E}+00$ & $0.00 \mathrm{E}+00$ & $0.00 \mathrm{E}+00$ & $0.00 \mathrm{E}+00$ & $0.00 \mathrm{E}+00$ & $0.00 \mathrm{E}+00$ & $0.00 \mathrm{E}+00$ & $0.00 \mathrm{E}+00$ & $5.73 E-02$ & $0.00 \mathrm{E}+00$ \\
\hline $4.30 \mathrm{E}+02$ & $E+00$ & $0.00 \mathrm{E}+00$ & $0.00 \mathrm{E}+00$ & $0.00 \mathrm{E}+00$ & $0.00 \mathrm{E}+00$ & $0.00 \mathrm{E}+00$ & $0.00 \mathrm{E}+00$ & $0.00 \mathrm{E}+00$ & $5.87 \mathrm{E}-02$ & $0.00 \mathrm{E}+00$ \\
\hline $4.40 \mathrm{E}+02$ & $1.61 \mathrm{E}+00$ & $0.00 \mathrm{E}+00$ & $0.00 \mathrm{E}+00$ & $0.00 \mathrm{E}+00$ & $0.00 \mathrm{E}+00$ & $0.00 \mathrm{E}+00$ & $0.00 \mathrm{E}+00$ & $0.00 \mathrm{E}+00$ & $6.25 \mathrm{E}-02$ & $0.00 \mathrm{E}+00$ \\
\hline $4.50 \mathrm{E}+02$ & $1.59 \mathrm{E}+00$ & $0.00 \mathrm{E}+00$ & $0.00 \mathrm{E}+00$ & $0.00 \mathrm{E}+00$ & $0.00 \mathrm{E}+00$ & $0.00 \mathrm{E}+00$ & $0.00 \mathrm{E}+00$ & $0.00 \mathrm{E}+00$ & $6.63 \mathrm{E}-02$ & $0.00 \mathrm{E}+00$ \\
\hline $4.60 \mathrm{E}+02$ & $1.58 \mathrm{E}+00$ & $0.00 \mathrm{E}+00$ & $0.00 \mathrm{E}+00$ & $0.00 \mathrm{E}+00$ & $0.00 \mathrm{E}+00$ & $0.00 \mathrm{E}+00$ & $0.00 \mathrm{E}+00$ & $0.00 \mathrm{E}+00$ & $7.01 \mathrm{E}-02$ & $0.00 \mathrm{E}+00$ \\
\hline $4.70 \mathrm{E}+02$ & $1.56 \mathrm{E}+00$ & $0.00 \mathrm{E}+00$ & $0.00 \mathrm{E}+00$ & $0.00 \mathrm{E}+00$ & $0.00 \mathrm{E}+00$ & $0.00 \mathrm{E}+00$ & $0.00 \mathrm{E}+00$ & $0.00 \mathrm{E}+00$ & $7.38 \mathrm{E}-02$ & $0.00 \mathrm{E}+00$ \\
\hline $4.80 \mathrm{E}+02$ & $1.55 \mathrm{E}+00$ & $0.00 \mathrm{E}+00$ & $0.00 \mathrm{E}+00$ & $0.00 \mathrm{E}+00$ & $0.00 \mathrm{E}+00$ & $0.00 \mathrm{E}+00$ & $0.00 \mathrm{E}+00$ & $0.00 \mathrm{E}+00$ & 7.74E-02 & $0.00 \mathrm{E}+00$ \\
\hline $4.90 \mathrm{E}+02$ & $1.53 \mathrm{E}+00$ & $0.00 \mathrm{E}+00$ & $0.00 \mathrm{E}+00$ & $0.00 \mathrm{E}+00$ & $0.00 \mathrm{E}+00$ & $0.00 \mathrm{E}+00$ & $0.00 \mathrm{E}+00$ & $0.00 \mathrm{E}+00$ & $7.76 \mathrm{E}-02$ & $0.00 \mathrm{E}+00$ \\
\hline $5.00 \mathrm{E}+02$ & $1.52 \mathrm{E}+00$ & $0.00 \mathrm{E}+00$ & $0.00 \mathrm{E}+00$ & $0.00 \mathrm{E}+00$ & $0.00 \mathrm{E}+00$ & $0.00 \mathrm{E}+00$ & $0.00 \mathrm{E}+00$ & $0.00 \mathrm{E}+00$ & $7.58 \mathrm{E}-02$ & $0.00 \mathrm{E}+00$ \\
\hline $5.10 \mathrm{E}+02$ & $1.50 \mathrm{E}+00$ & $0.00 \mathrm{E}+00$ & $0.00 \mathrm{E}+00$ & $0.00 \mathrm{E}+00$ & $0.00 \mathrm{E}+00$ & $0.00 \mathrm{E}+00$ & $0.00 \mathrm{E}+00$ & $0.00 \mathrm{E}+00$ & $7.38 \mathrm{E}-02$ & $0.00 \mathrm{E}+00$ \\
\hline $5.20 \mathrm{E}+02$ & $1.48 \mathrm{E}+00$ & $0.00 \mathrm{E}+00$ & $0.00 \mathrm{E}+00$ & $0.00 \mathrm{E}+00$ & $0.00 \mathrm{E}+00$ & $0.00 \mathrm{E}+00$ & $0.00 \mathrm{E}+00$ & $0.00 \mathrm{E}+00$ & $7.19 \mathrm{E}-02$ & $0.00 \mathrm{E}+00$ \\
\hline $5.30 \mathrm{E}+02$ & $1.47 \mathrm{E}+00$ & $0.00 \mathrm{E}+00$ & $0.00 \mathrm{E}+00$ & $0.00 \mathrm{E}+00$ & $0.00 \mathrm{E}+00$ & $0.00 \mathrm{E}+00$ & $0.00 \mathrm{E}+00$ & $0.00 \mathrm{E}+00$ & $7.01 \mathrm{E}-02$ & $0.00 \mathrm{E}+00$ \\
\hline $5.40 \mathrm{E}+02$ & $1.45 \mathrm{E}+00$ & $0.00 \mathrm{E}+00$ & $0.00 \mathrm{E}+00$ & $0.00 \mathrm{E}+00$ & $0.00 \mathrm{E}+00$ & $0.00 \mathrm{E}+00$ & $0.00 \mathrm{E}+00$ & $0.00 \mathrm{E}+00$ & $6.85 \mathrm{E}-02$ & $0.00 \mathrm{E}+00$ \\
\hline $5.50 \mathrm{E}+02$ & $1.44 \mathrm{E}+00$ & $0.00 \mathrm{E}+00$ & $0.00 \mathrm{E}+00$ & $0.00 \mathrm{E}+00$ & $0.00 \mathrm{E}+00$ & $0.00 \mathrm{E}+00$ & $0.00 \mathrm{E}+00$ & $0.00 \mathrm{E}+00$ & $5.95 \mathrm{E}-02$ & $0.00 \mathrm{E}+00$ \\
\hline $5.60 \mathrm{E}+02$ & $1.43 \mathrm{E}+00$ & $0.00 \mathrm{E}+00$ & $0.00 \mathrm{E}+00$ & $0.00 \mathrm{E}+00$ & $0.00 \mathrm{E}+00$ & $0.00 \mathrm{E}+00$ & $0.00 \mathrm{E}+00$ & $0.00 \mathrm{E}+00$ & $4.61 \mathrm{E}-02$ & $0.00 \mathrm{E}+00$ \\
\hline $5.70 \mathrm{E}+02$ & $1.42 \mathrm{E}+00$ & $0.00 \mathrm{E}+00$ & $0.00 \mathrm{E}+00$ & $0.00 \mathrm{E}+00$ & $0.00 \mathrm{E}+00$ & $0.00 \mathrm{E}+00$ & $0.00 \mathrm{E}+00$ & $0.00 \mathrm{E}+00$ & $3.27 \mathrm{E}-02$ & $0.00 \mathrm{E}+00$ \\
\hline $5.80 \mathrm{E}+02$ & $1.42 \mathrm{E}+00$ & $0.00 \mathrm{E}+00$ & $0.00 \mathrm{E}+00$ & $0.00 \mathrm{E}+00$ & $0.00 \mathrm{E}+00$ & $0.00 \mathrm{E}+00$ & $0.00 \mathrm{E}+00$ & $0.00 \mathrm{E}+00$ & $1.99 \mathrm{E}-02$ & $0.00 \mathrm{E}+00$ \\
\hline $5.90 \mathrm{E}+02$ & $1.41 \mathrm{E}+00$ & $0.00 \mathrm{E}+00$ & $0.00 \mathrm{E}+00$ & $0.00 \mathrm{E}+00$ & $0.00 \mathrm{E}+00$ & $0.00 \mathrm{E}+00$ & $0.00 \mathrm{E}+00$ & $0.00 \mathrm{E}+00$ & 7.67E-03 & $0.00 \mathrm{E}+00$ \\
\hline
\end{tabular}




\section{Heat Release Rate}

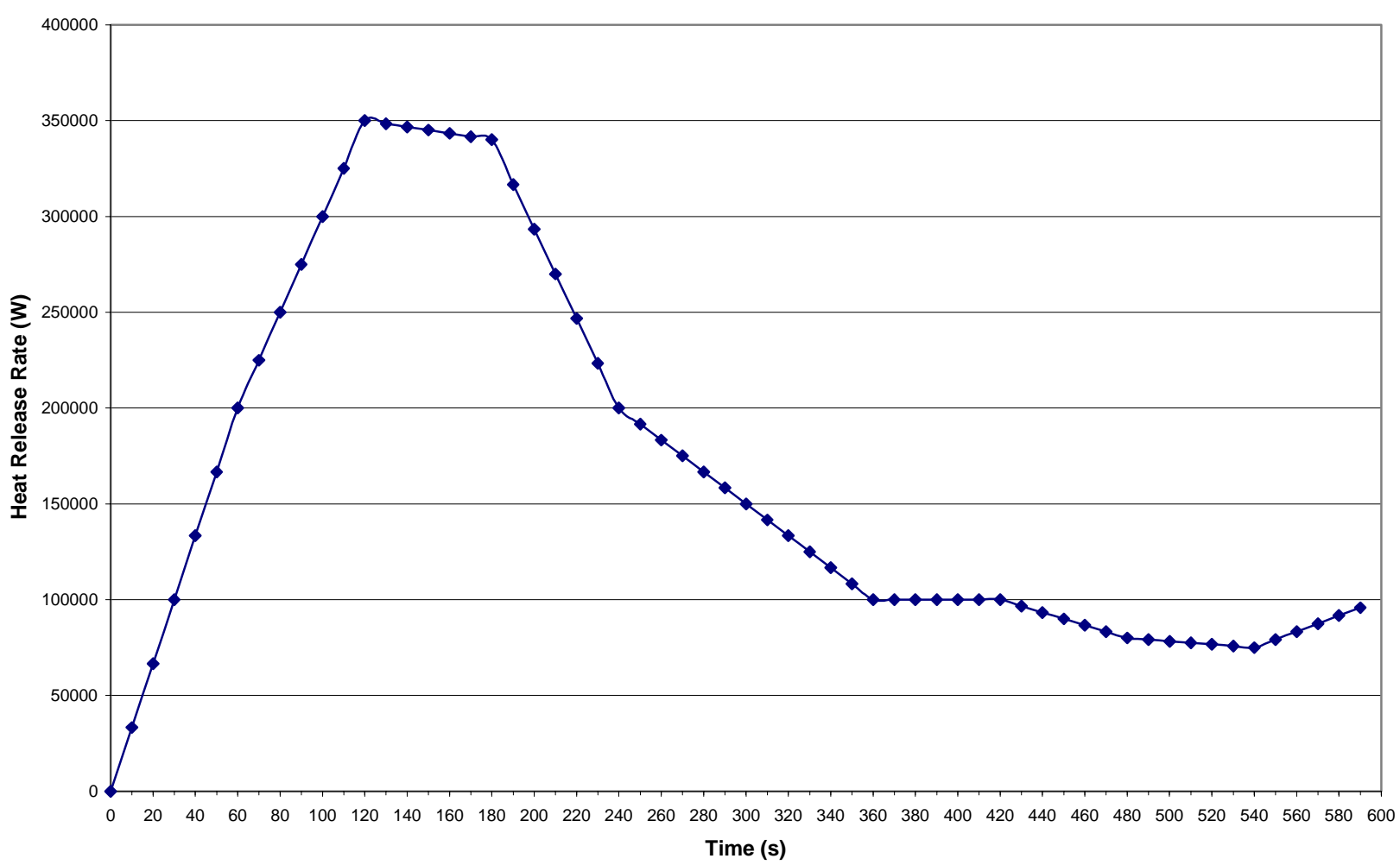

Oxygen Concentration

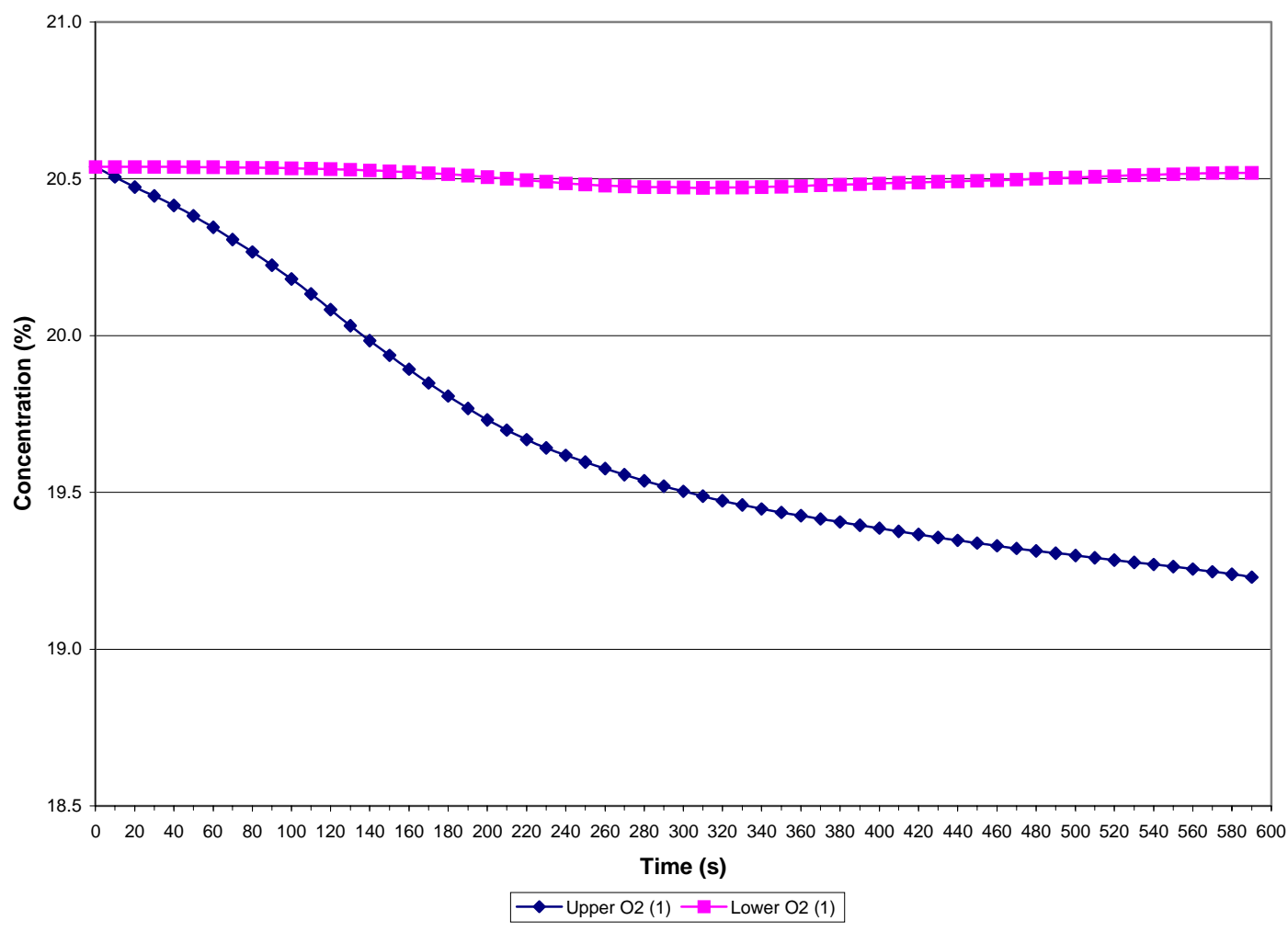




\section{Main Plume Flow}

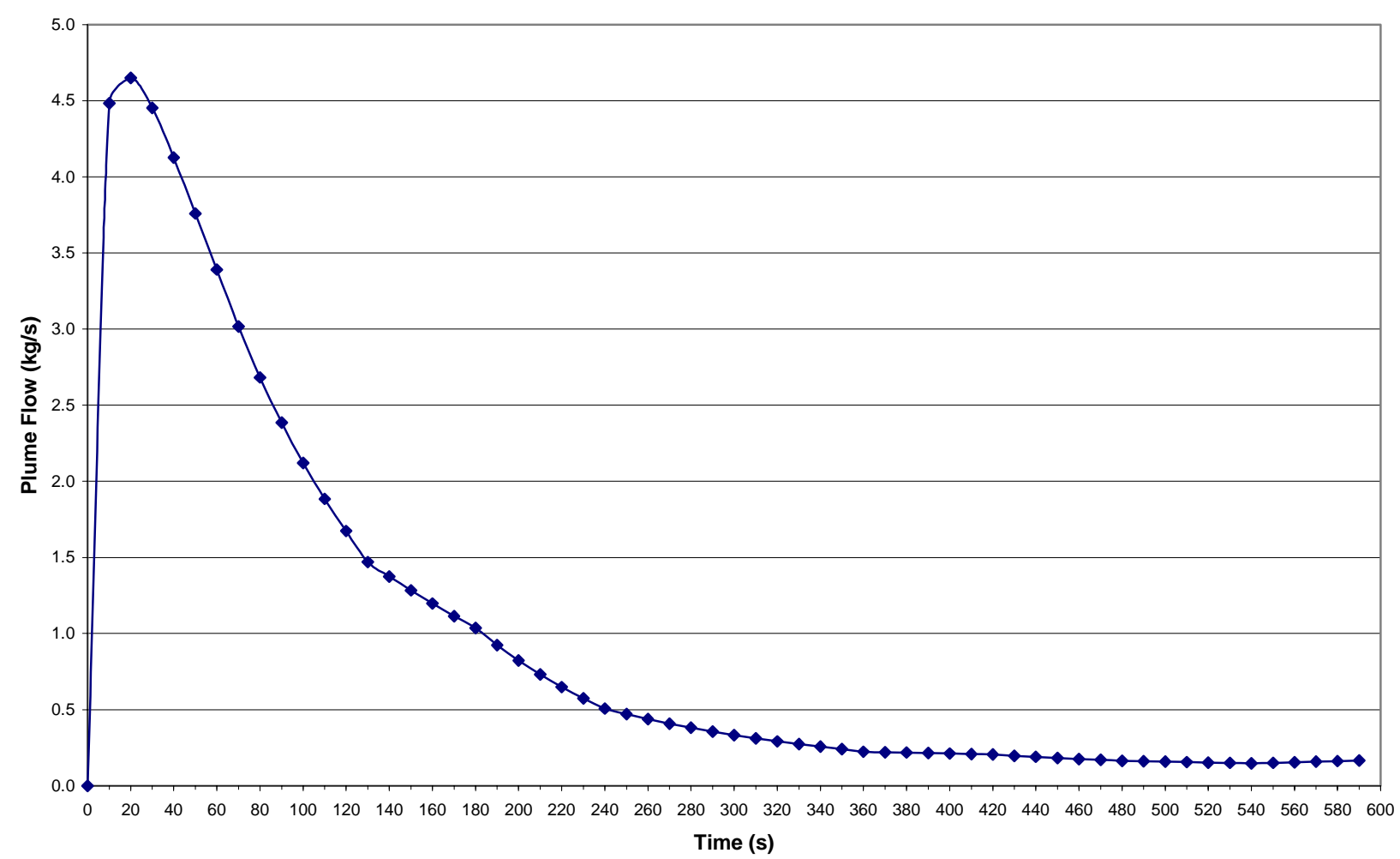

Pressure

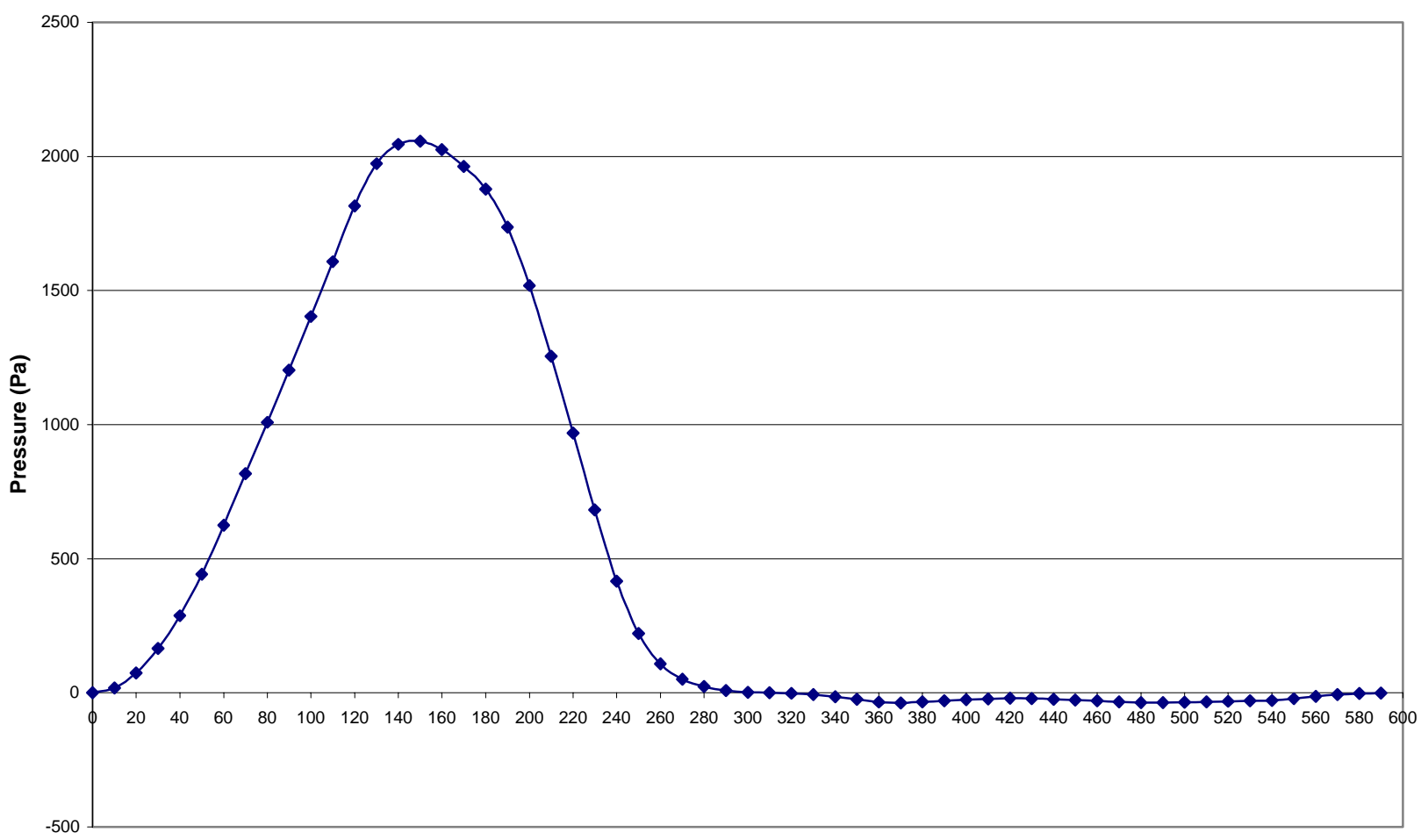

Time (s) 


\section{Lower Layer Outflow}

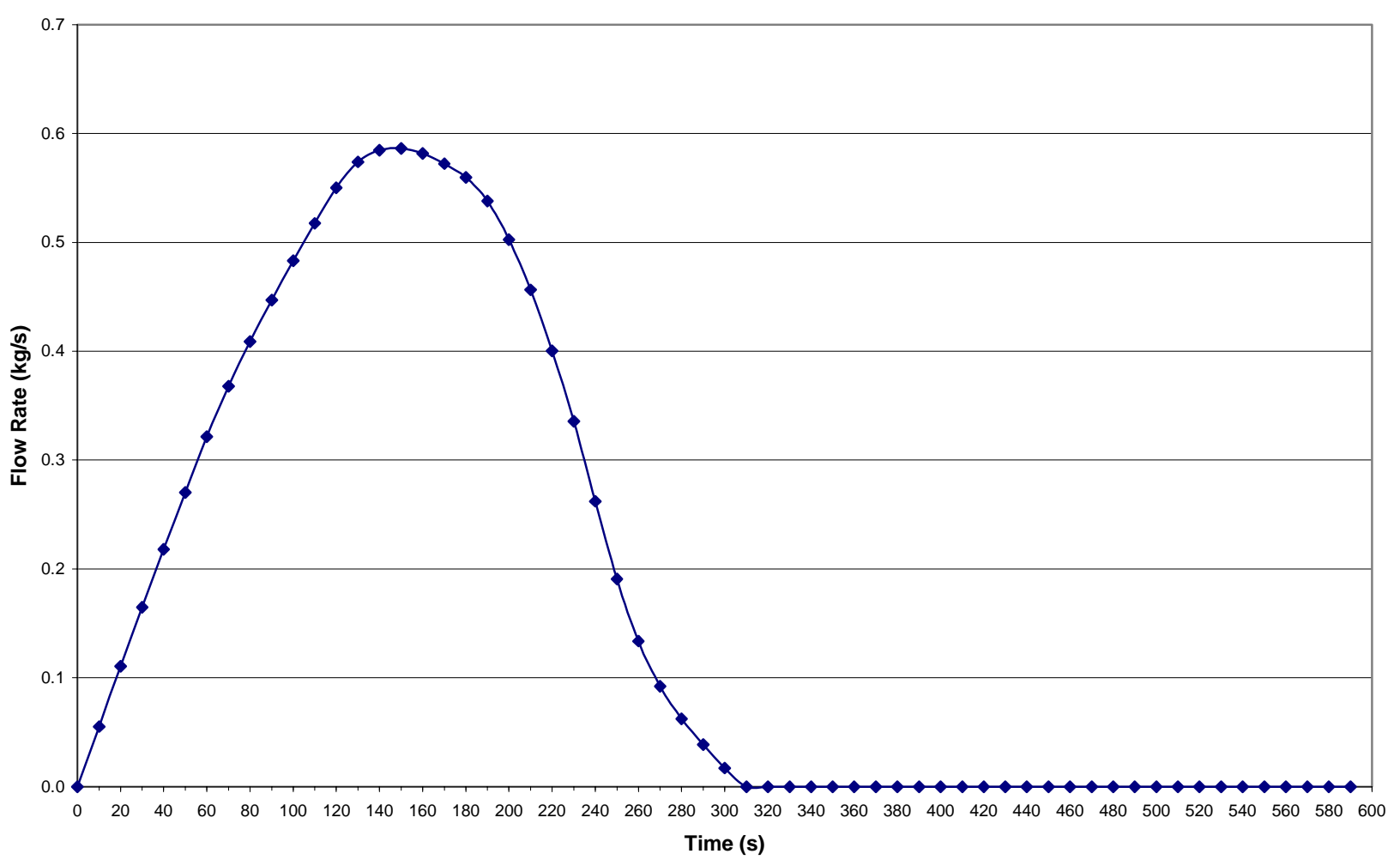

Lower Layer Inflow

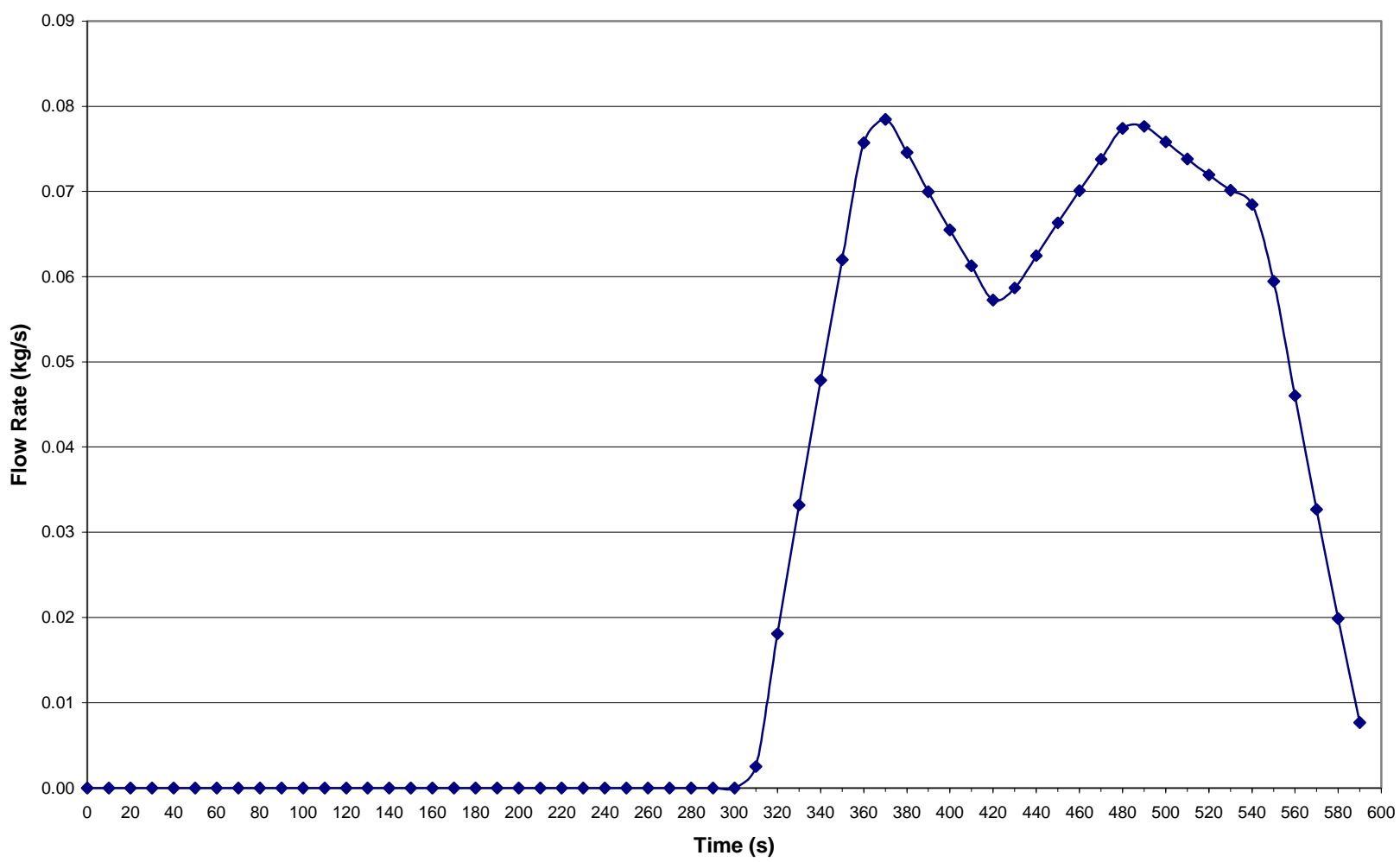




\section{Layer Height}

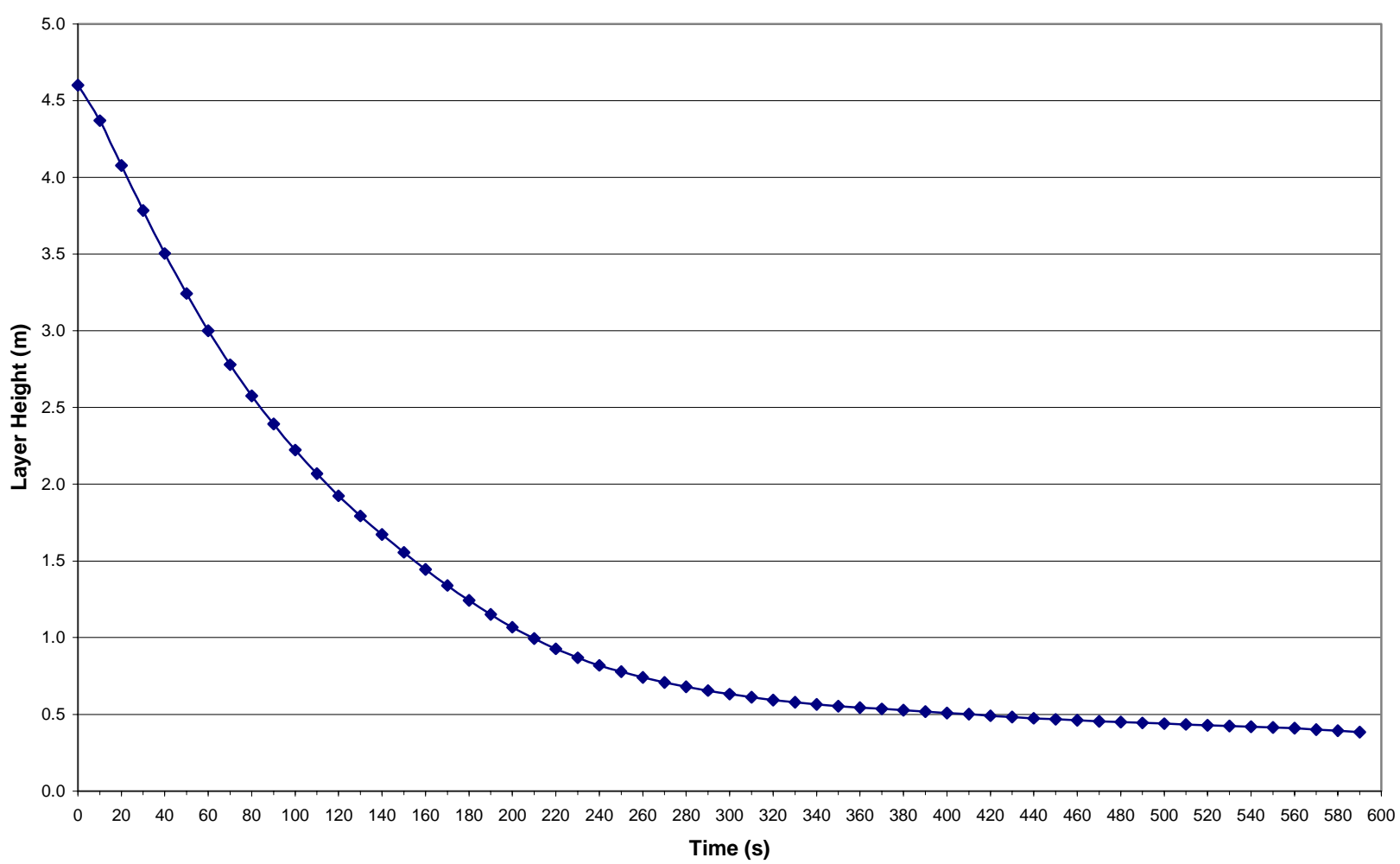

Upper Layer Temperature

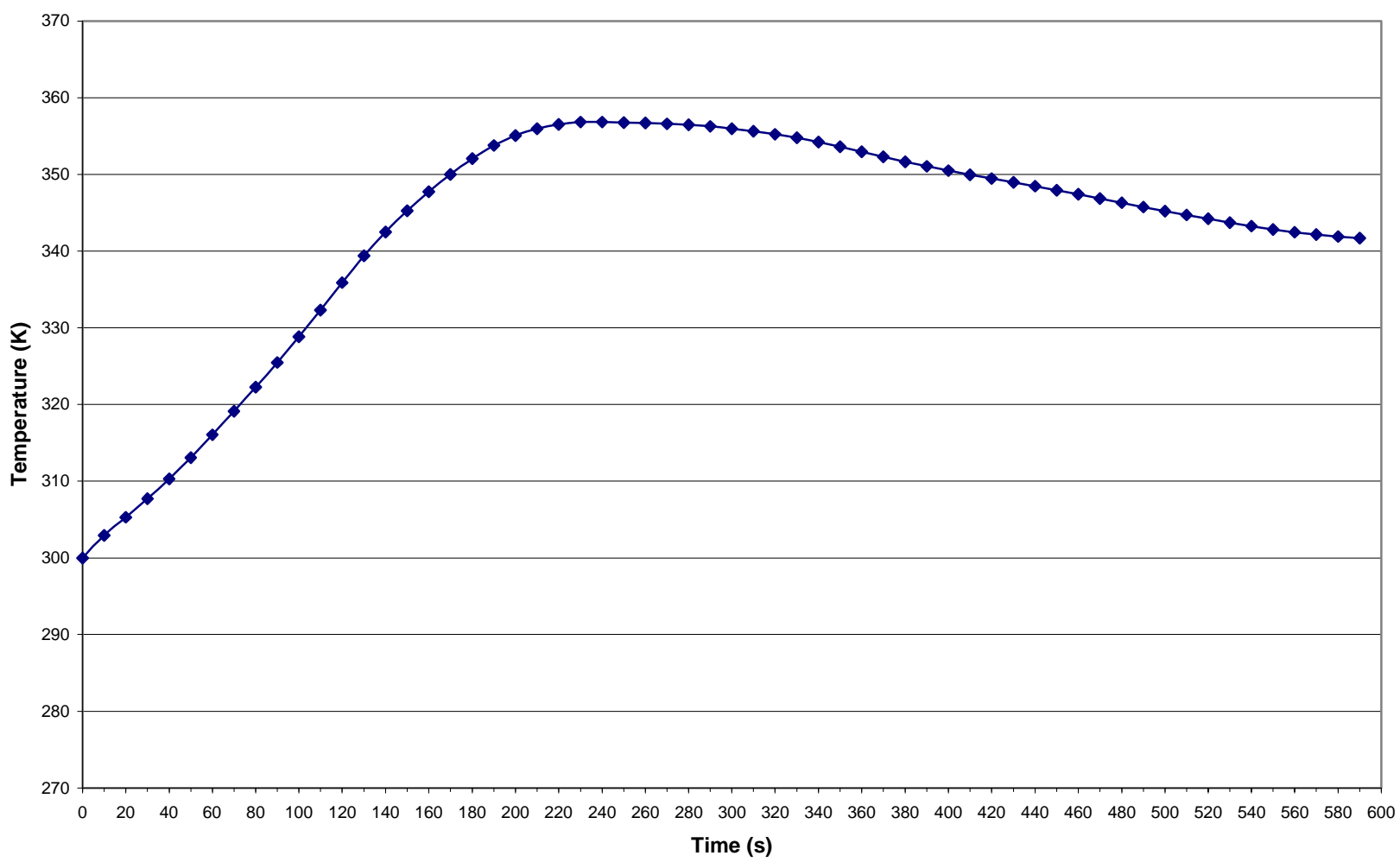


Incident Flux on Target

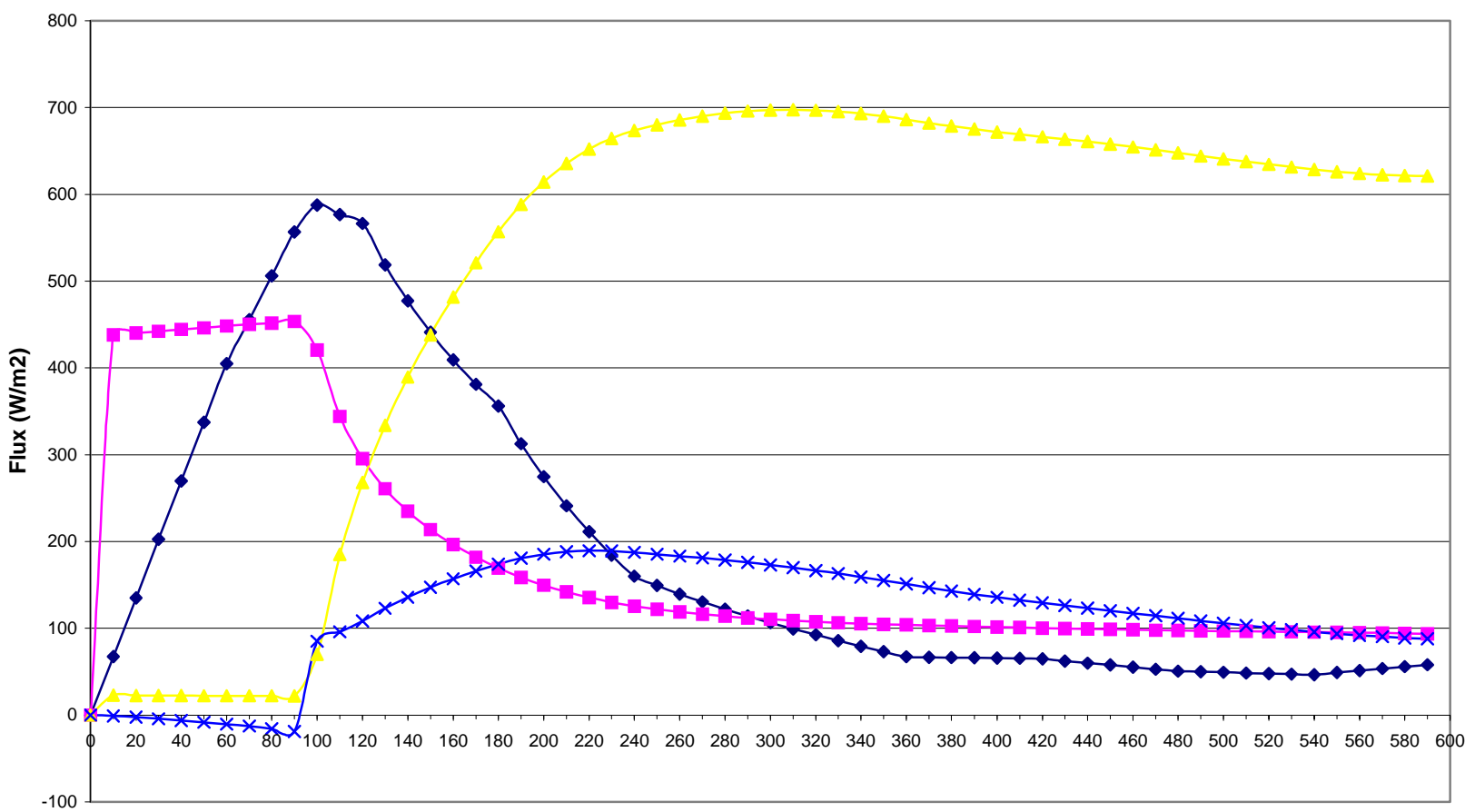

Time (s)

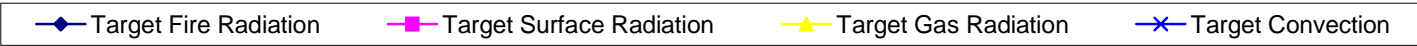

Target Surface Temperature

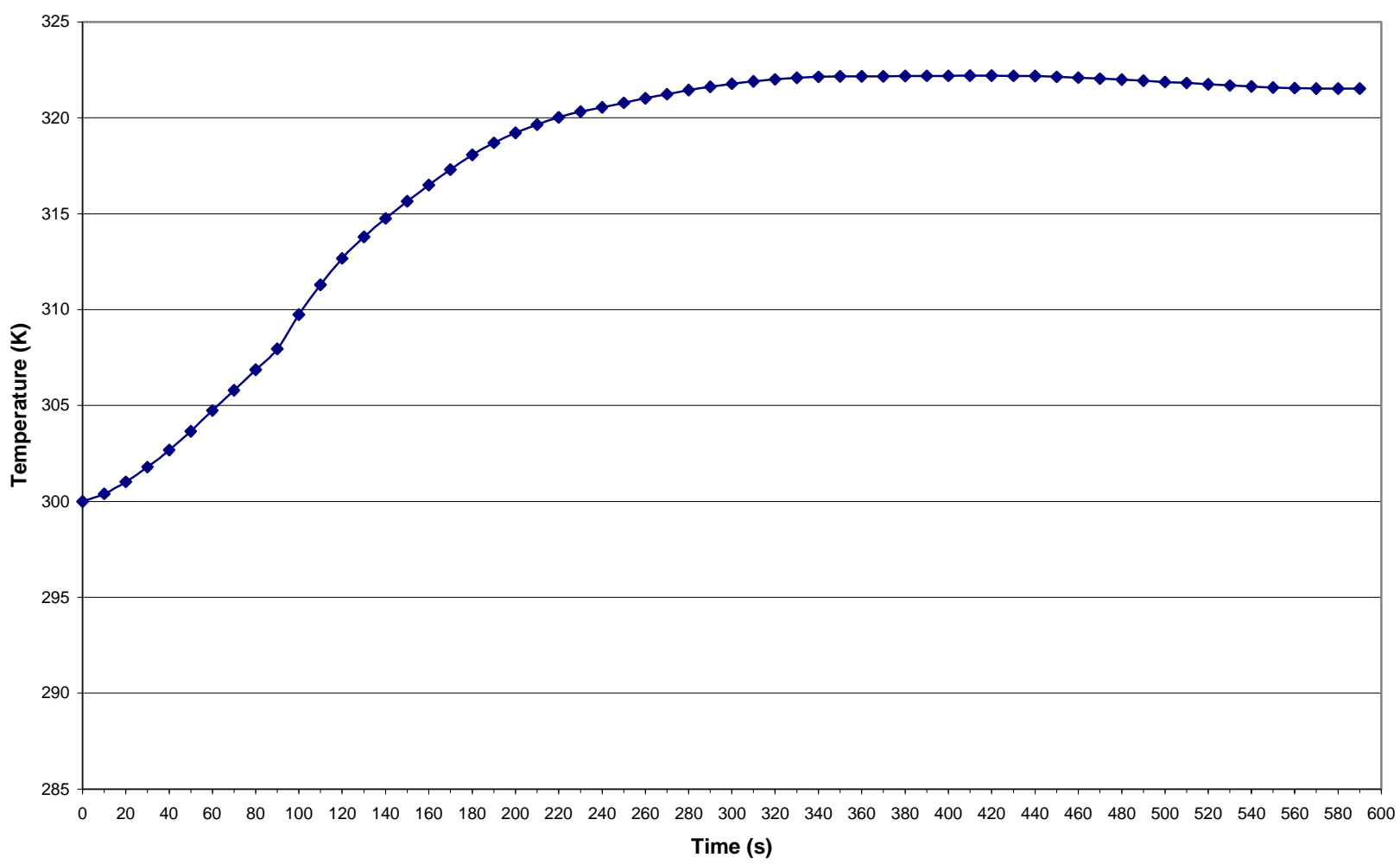


This page intentionally blank. 
Appendix 6 - LITE.LST Report for Verification Effort 
CFAST Version $3.1 .6 \quad$ PART 1 - BASE CASE

Data file is BASECASE.DAT (Checksum 00000000)

OVERVIEW

Compartments Doors, ... Ceil. Vents, ... MV Connects

$\begin{array}{llll}1 & 1 & 0 & 0\end{array}$

Simulation $\quad$ Print $\quad$ History $\quad$ Restart

$(\mathrm{s}) \quad(\mathrm{s}) \quad(\mathrm{s}) \quad(\mathrm{s})$

$\begin{array}{llll}600 & 10 & 10 & 0\end{array}$

Ceiling jet is on for all

History file is $\mathrm{C}: \backslash \mathrm{A} \backslash \mathrm{BASECASE}$. HI

AMBIENT CONDITIONS

\begin{tabular}{|c|c|c|c|c|c|c|c|}
\hline Interior & Interior & Exterior & Exterior & Station & Wind & Wind & Wind \\
\hline $\begin{array}{l}\text { Temperature } \\
(\mathrm{K})\end{array}$ & $\begin{array}{l}\text { Pressure } \\
(\mathrm{Pa})\end{array}$ & $\begin{array}{l}\text { Temperature } \\
(\mathrm{K})\end{array}$ & $\begin{array}{l}\text { Pressure } \\
\quad(\mathrm{Pa})\end{array}$ & $\begin{array}{l}\text { Elevation } \\
(\mathrm{m})\end{array}$ & $\begin{array}{l}\text { Speed } \\
(\mathrm{m} / \mathrm{s})\end{array}$ & $\begin{array}{l}\text { Ref. Height } \\
\text { (m) }\end{array}$ & Power \\
\hline 300 . & 101300 . & 300 . & 101300 . & 0.00 & 0.0 & 10.0 & 0.16 \\
\hline
\end{tabular}

COMPARTMENTS

Compartment Width Depth Height Area Volume Ceiling Floor

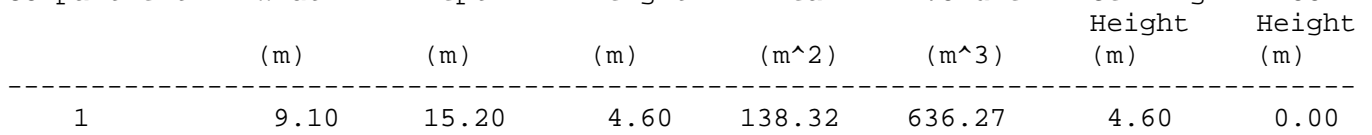

VENT CONNECTIONS

Horizontal Natural Flow Connections (Doors, Windows, ...)

\begin{tabular}{|c|c|c|c|c|c|c|c|c|}
\hline $\begin{array}{l}\text { From } \\
\text { Compartment }\end{array}$ & $\begin{array}{l}\text { To } \\
\text { Compartment }\end{array}$ & $\begin{array}{l}\text { Vent } \\
\text { Number } \\
\text { (m) }\end{array}$ & $\begin{array}{l}\text { Width } \\
\text { (m) }\end{array}$ & $\begin{array}{l}\text { Sill } \\
\text { Height } \\
(\mathrm{m})\end{array}$ & $\begin{array}{l}\text { Soffit } \\
\text { Height } \\
(\mathrm{m})\end{array}$ & $\begin{array}{l}\text { Abs. } \\
\text { Sill } \\
\text { (m) }\end{array}$ & $\begin{array}{l}\text { Abs. } \\
\text { Soffit } \\
\text { (m) }\end{array}$ & $\begin{array}{l}\text { Area } \\
\left(m^{\wedge} 2\right)\end{array}$ \\
\hline 1 & Outside & 1 & 2.40 & 0.00 & 0.00 & 0.00 & 0.00 & 0.01 \\
\hline
\end{tabular}

There are no vertical natural flow connections

There are no mechanical flow connections

THERMAL PROPERTIES

\begin{tabular}{|c|c|c|c|}
\hline Compartment & Ceiling & Wall & Floor \\
\hline 1 & $\mathrm{CONCO} 03$ & $\mathrm{CONC} 003$ & $\mathrm{CONC} 003$ \\
\hline
\end{tabular}

Thermal data base used: C: \A \WSMSTH02.DF

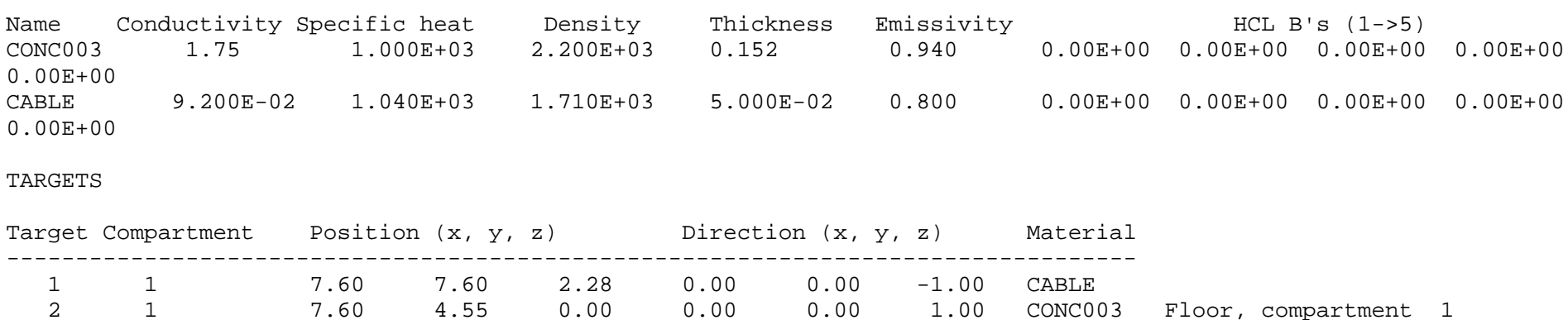


WSRC-TR-2001-00405

FIRES

Name: Main Fire

\begin{tabular}{|c|c|c|c|c|c|c|c|c|c|c|}
\hline \multirow{3}{*}{$\begin{array}{l}\text { Compartment } \\
\qquad \begin{array}{l}1 \\
\text { Time } \\
\text { (s) }\end{array}\end{array}$} & \multicolumn{2}{|c|}{ Fire Type } & \multicolumn{2}{|c|}{ Position $(x, y, z)$} & \multirow{3}{*}{$\begin{array}{l}\text { Relative } \\
\text { Humidity } \\
50.0 \\
\mathrm{C} / \mathrm{CO} 2 \\
(\mathrm{~kg} / \mathrm{kg})\end{array}$} & \multirow{2}{*}{$\begin{array}{l}\text { Lower } 0 \\
\text { Limit } \\
12.00\end{array}$} & \multirow{2}{*}{\multicolumn{2}{|c|}{$\begin{array}{l}\text { Pyrolysis } \\
\text { Temperature } \\
300 .\end{array}$}} & \multirow[b]{3}{*}{$\begin{array}{l}\mathrm{HCN} \\
(\mathrm{kg} / \mathrm{kg})\end{array}$} & \multirow[b]{3}{*}{$\begin{array}{l}\mathrm{HCL} \\
(\mathrm{kg} / \mathrm{kg})\end{array}$} \\
\hline & \multicolumn{2}{|c|}{ Constrained } & 7.60 & 0.00 & & & & & & \\
\hline & $\begin{array}{l}\text { Fmass } \\
(\mathrm{kg} / \mathrm{s})\end{array}$ & $\begin{array}{l}\text { Hcomb } \\
(\mathrm{J} / \mathrm{kg})\end{array}$ & $\begin{array}{l}\text { Fqdot } \\
(W)\end{array}$ & $\begin{array}{l}\text { Fhigh } \\
(\mathrm{m})\end{array}$ & & $\begin{array}{c}\mathrm{CO} / \mathrm{CO} 2 \\
(\mathrm{~kg} / \mathrm{kg})\end{array}$ & $\begin{array}{l}\mathrm{H} / \mathrm{C} \\
(\mathrm{kg} / \mathrm{kg})\end{array}$ & $\begin{array}{l}\text { O/C } \\
(\mathrm{kg} / \mathrm{kg})\end{array}$ & & \\
\hline 0 . & $0.00 \mathrm{E}+00$ & $2.41 E+07$ & $0.00 \mathrm{E}+00$ & $0.00 \mathrm{E}+00$ & $0.00 \mathrm{E}+00$ & $0.00 \mathrm{E}+00$ & 0.16 & $0.00 \mathrm{E}+00$ & $0.00 E+00$ & $0.00 \mathrm{E}+00$ \\
\hline 60. & $8.30 E-03$ & $2.41 E+07$ & $2.00 \mathrm{E}+05$ & $0.00 \mathrm{E}+00$ & $0.00 \mathrm{E}+00$ & $0.00 \mathrm{E}+00$ & 0.16 & $0.00 \mathrm{E}+00$ & $0.00 \mathrm{E}+00$ & $0.00 \mathrm{E}+00$ \\
\hline 120 . & 1. $45 \mathrm{E}-02$ & $2.41 E+07$ & $3.50 \mathrm{E}+05$ & $0.00 \mathrm{E}+00$ & $0.00 \mathrm{E}+00$ & $0.00 \mathrm{E}+00$ & 0.16 & $0.00 \mathrm{E}+00$ & $0.00 \mathrm{E}+00$ & $0.00 \mathrm{E}+00$ \\
\hline 180. & $1.41 \mathrm{E}-02$ & $2.41 E+07$ & $3.40 \mathrm{E}+05$ & $0.00 \mathrm{E}+00$ & $0.00 \mathrm{E}+00$ & $0.00 \mathrm{E}+00$ & 0.16 & $0.00 \mathrm{E}+00$ & $0.00 \mathrm{E}+00$ & $0.00 \mathrm{E}+00$ \\
\hline 240 . & $8.30 E-03$ & $2.41 E+07$ & $2.00 \mathrm{E}+05$ & $0.00 \mathrm{E}+00$ & $0.00 \mathrm{E}+00$ & $0.00 \mathrm{E}+00$ & 0.16 & $0.00 \mathrm{E}+00$ & $0.00 \mathrm{E}+00$ & $0.00 \mathrm{E}+00$ \\
\hline 300 & $6.22 \mathrm{E}-03$ & $2.41 E+07$ & $1.50 \mathrm{E}+05$ & $0.00 \mathrm{E}+00$ & $0.00 \mathrm{E}+00$ & $0.00 \mathrm{E}+00$ & 0.16 & $0.00 \mathrm{E}+00$ & $0.00 \mathrm{E}+00$ & $0.00 \mathrm{E}+00$ \\
\hline 360. & $4.15 \mathrm{E}-03$ & $2.41 E+07$ & $1.00 \mathrm{E}+05$ & $0.00 \mathrm{E}+00$ & $0.00 \mathrm{E}+00$ & $0.00 E+00$ & 0.16 & $0.00 \mathrm{E}+00$ & $0.00 \mathrm{E}+00$ & $0.00 \mathrm{E}+00$ \\
\hline 420 . & $4.15 \mathrm{E}-03$ & $2.41 E+07$ & $1.00 \mathrm{E}+05$ & $0.00 \mathrm{E}+00$ & $0.00 \mathrm{E}+00$ & $0.00 \mathrm{E}+00$ & 0.16 & $0.00 \mathrm{E}+00$ & $0.00 \mathrm{E}+00$ & $0.00 \mathrm{E}+00$ \\
\hline 480 & $3.32 \mathrm{E}-03$ & $2.41 \mathrm{E}+07$ & $8.00 \mathrm{E}+04$ & $0.00 \mathrm{E}+00$ & $0.00 \mathrm{E}+00$ & $0.00 \mathrm{E}+00$ & 0.16 & $0.00 \mathrm{E}+00$ & $0.00 \mathrm{E}+00$ & $0.00 \mathrm{E}+00$ \\
\hline 540. & $3.11 \mathrm{E}-03$ & $2.41 E+07$ & $7.50 \mathrm{E}+04$ & $0.00 \mathrm{E}+00$ & $0.00 \mathrm{E}+00$ & $0.00 \mathrm{E}+00$ & 0.16 & $0.00 \mathrm{E}+00$ & $0.00 \mathrm{E}+00$ & $0.00 \mathrm{E}+00$ \\
\hline 600. & $4.15 E-03$ & $2.41 E+07$ & $1.00 \mathrm{E}+05$ & $0.00 \mathrm{E}+00$ & $0.00 \mathrm{E}+00$ & $0.00 \mathrm{E}+00$ & 0.16 & $0.00 E+00$ & $0.00 E+00$ & $0.00 \mathrm{E}+00$ \\
\hline
\end{tabular}

\begin{tabular}{|c|c|c|c|c|c|c|c|}
\hline Compartment & $\begin{array}{l}\text { Upper } \\
\text { Temp. } \\
(\mathrm{K})\end{array}$ & $\begin{array}{l}\text { Lower } \\
\text { Temp. } \\
(\mathrm{K})\end{array}$ & $\begin{array}{l}\text { Inter. } \\
\text { Height } \\
(\mathrm{m})\end{array}$ & $\begin{array}{l}\text { Pyrol } \\
\text { Rate } \\
(\mathrm{kg} / \mathrm{s})\end{array}$ & $\begin{array}{l}\text { Fire } \\
\text { Size } \\
(W)\end{array}$ & $\begin{array}{l}\text { Pressure } \\
(\mathrm{Pa})\end{array}$ & $\begin{array}{l}\text { Ambient } \\
\text { Target } \\
\left(\mathrm{W} / \mathrm{m}^{\wedge} 2\right)\end{array}$ \\
\hline $\begin{array}{c}1 \\
\text { Outside }\end{array}$ & 300.0 & 300.0 & 4.6 & $0.000 \mathrm{E}+00$ & $\begin{array}{l}0.000 \mathrm{E}+00- \\
0.000 \mathrm{E}+00\end{array}$ & $-1.477 \mathrm{E}-18$ & $0.000 \mathrm{E}+00$ \\
\hline Time $=$ & $10.0 \mathrm{secc}$ & ds. & & & & & \\
\hline Compartment & $\begin{array}{l}\text { Upper } \\
\text { Temp. } \\
(\mathrm{K})\end{array}$ & $\begin{array}{l}\text { Lower } \\
\text { Temp. } \\
(\mathrm{K})\end{array}$ & $\begin{array}{l}\text { Inter. } \\
\text { Height } \\
(\mathrm{m})\end{array}$ & $\begin{array}{l}\text { Pyrol } \\
\text { Rate } \\
(\mathrm{kg} / \mathrm{s})\end{array}$ & $\begin{array}{l}\text { Fire } \\
\text { Size } \\
(W)\end{array}$ & $\begin{array}{l}\text { Pressure } \\
(\mathrm{Pa})\end{array}$ & $\begin{array}{l}\text { Ambient } \\
\text { Target } \\
\left(\mathrm{W} / \mathrm{m}^{\wedge} 2\right)\end{array}$ \\
\hline $\begin{array}{c}1 \\
\text { Outside }\end{array}$ & 303.0 & 300.0 & 4.4 & $1.383 \mathrm{E}-03$ & $\begin{array}{l}3.333 E+04 \\
0.000 E+00\end{array}$ & 18.5 & 2.10 \\
\hline Time $=$ & $20.0 \mathrm{secc}$ & ds. & & & & & \\
\hline Compartment & $\begin{array}{l}\text { Upper } \\
\text { Temp. } \\
(\mathrm{K})\end{array}$ & $\begin{array}{l}\text { Lower } \\
\text { Temp. } \\
(\mathrm{K})\end{array}$ & $\begin{array}{l}\text { Inter. } \\
\text { Height } \\
(\mathrm{m})\end{array}$ & $\begin{array}{l}\text { Pyrol } \\
\text { Rate } \\
(\mathrm{kg} / \mathrm{s})\end{array}$ & $\begin{array}{l}\text { Fire } \\
\text { Size } \\
(W)\end{array}$ & $\begin{array}{l}\text { Pressure } \\
(\mathrm{Pa})\end{array}$ & $\begin{array}{l}\text { Ambient } \\
\text { Target } \\
\left(W / m^{\wedge} 2\right)\end{array}$ \\
\hline $\begin{array}{c}1 \\
\text { Outside }\end{array}$ & 305.3 & 300.1 & 4.1 & $2.766 \mathrm{E}-03$ & $\begin{array}{l}6.667 E+04 \\
0.000 E+00\end{array}$ & 74.1 & 5.57 \\
\hline Time $=$ & $30.0 \mathrm{sec}$ & ds. & & & & & \\
\hline Compartment & $\begin{array}{l}\text { Upper } \\
\text { Temp. } \\
(\mathrm{K})\end{array}$ & $\begin{array}{l}\text { Lower } \\
\text { Temp. } \\
(\mathrm{K})\end{array}$ & $\begin{array}{l}\text { Inter. } \\
\text { Height } \\
(\mathrm{m})\end{array}$ & $\begin{array}{l}\text { Pyrol } \\
\text { Rate } \\
(\mathrm{kg} / \mathrm{s})\end{array}$ & $\begin{array}{l}\text { Fire } \\
\text { Size } \\
(W)\end{array}$ & $\begin{array}{l}\text { Pressure } \\
(\mathrm{Pa})\end{array}$ & $\begin{array}{l}\text { Ambient } \\
\text { Target } \\
\left(W / m^{\wedge} 2\right)\end{array}$ \\
\hline$\frac{1}{\text { Outside }}$ & 307.7 & 300.2 & 3.8 & $4.149 \mathrm{E}-03$ & $\begin{array}{l}1.000 E+05 \\
0.000 E+00\end{array}$ & 165 . & 10.4 \\
\hline Time $=$ & $40.0 \mathrm{sec}$ & ds. & & & & & \\
\hline Compartment & $\begin{array}{l}\text { Upper } \\
\text { Temp. } \\
(\mathrm{K})\end{array}$ & $\begin{array}{l}\text { Lower } \\
\text { Temp. } \\
(\mathrm{K})\end{array}$ & $\begin{array}{l}\text { Inter. } \\
\text { Height } \\
(\mathrm{m})\end{array}$ & $\begin{array}{l}\text { Pyrol } \\
\text { Rate } \\
(\mathrm{kg} / \mathrm{s})\end{array}$ & $\begin{array}{l}\text { Fire } \\
\text { Size } \\
(W)\end{array}$ & $\begin{array}{l}\text { Pressure } \\
(\mathrm{Pa})\end{array}$ & $\begin{array}{l}\text { Ambient } \\
\text { Target } \\
\left(W / m^{\wedge} 2\right)\end{array}$ \\
\hline $\begin{array}{c}1 \\
\text { Outside }\end{array}$ & 310.3 & 300.3 & 3.5 & $5.533 \mathrm{E}-03$ & $\begin{array}{l}1.333 E+05 \\
0.000 E+00\end{array}$ & 288 & 16.8 \\
\hline Time $=$ & $50.0 \mathrm{secc}$ & ds. & & & & & \\
\hline Compartment & $\begin{array}{l}\text { Upper } \\
\text { Temp. } \\
(\mathrm{K})\end{array}$ & $\begin{array}{l}\text { Lower } \\
\text { Temp. } \\
(\mathrm{K})\end{array}$ & $\begin{array}{l}\text { Inter. } \\
\text { Height } \\
(\mathrm{m})\end{array}$ & $\begin{array}{l}\text { Pyrol } \\
\text { Rate } \\
(\mathrm{kg} / \mathrm{s})\end{array}$ & $\begin{array}{l}\text { Fire } \\
\text { Size } \\
(W)\end{array}$ & $\begin{array}{l}\text { Pressure } \\
(\mathrm{Pa})\end{array}$ & $\begin{array}{l}\text { Ambient } \\
\text { Target } \\
\left(\mathrm{W} / \mathrm{m}^{\wedge} 2\right)\end{array}$ \\
\hline$\frac{1}{\text { Outside }}$ & 313.1 & 300.4 & 3.2 & $6.916 E-03$ & $\begin{array}{l}1.667 \mathrm{E}+05 \\
0.000 \mathrm{E}+00\end{array}$ & 442 . & 24.7 \\
\hline
\end{tabular}




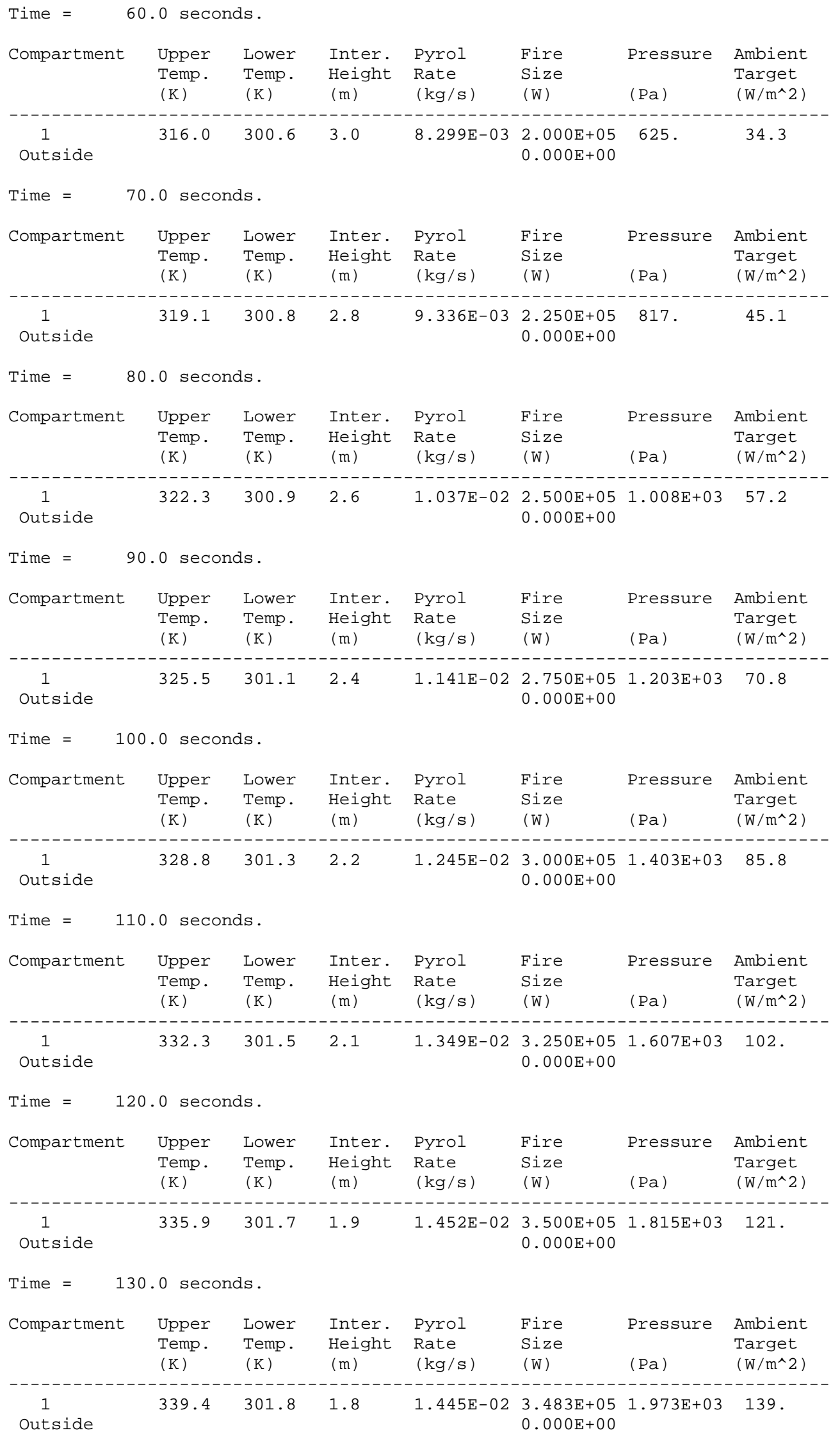




\begin{tabular}{|c|c|c|c|c|c|c|c|c|}
\hline Compartment & & $\begin{array}{l}\text { Upper } \\
\text { Temp. } \\
(\mathrm{K})\end{array}$ & $\begin{array}{l}\text { Lower } \\
\text { Temp. } \\
(\mathrm{K})\end{array}$ & $\begin{array}{l}\text { Inter. } \\
\text { Height } \\
\text { (m) }\end{array}$ & $\begin{array}{l}\text { Pyrol } \\
\text { Rate } \\
(\mathrm{kg} / \mathrm{s})\end{array}$ & $\begin{array}{l}\text { Fire } \\
\text { Size } \\
(W)\end{array}$ & $\begin{array}{l}\text { Pressure } \\
(\mathrm{Pa})\end{array}$ & $\begin{array}{l}\text { Ambient } \\
\text { Target } \\
\left(\mathrm{W} / \mathrm{m}^{\wedge} 2\right)\end{array}$ \\
\hline $\begin{array}{c}1 \\
\text { Outside }\end{array}$ & & 342.5 & 301.9 & 1.7 & $1.438 \mathrm{E}-02$ & $\begin{array}{l}3.466 \mathrm{E}+05 \\
0.000 \mathrm{E}+00\end{array}$ & $2.045 E+03$ & 156. \\
\hline Time $=$ & \multicolumn{8}{|c|}{150.0 seconds. } \\
\hline Compartment & & $\begin{array}{l}\text { Upper } \\
\text { Temp. } \\
(\mathrm{K})\end{array}$ & $\begin{array}{l}\text { Lower } \\
\text { Temp. } \\
(\mathrm{K})\end{array}$ & $\begin{array}{l}\text { Inter. } \\
\text { Height } \\
(\mathrm{m})\end{array}$ & $\begin{array}{l}\text { Pyrol } \\
\text { Rate } \\
(\mathrm{kg} / \mathrm{s})\end{array}$ & $\begin{array}{l}\text { Fire } \\
\text { Size } \\
\text { (W) }\end{array}$ & $\begin{array}{l}\text { Pressure } \\
(\mathrm{Pa})\end{array}$ & $\begin{array}{l}\text { Ambient } \\
\text { Target } \\
\left(\mathrm{W} / \mathrm{m}^{\wedge} 2\right)\end{array}$ \\
\hline $\begin{array}{c}1 \\
\text { Outside }\end{array}$ & & 345.2 & 302.0 & 1.6 & $1.432 \mathrm{E}-02$ & $\begin{array}{l}3.450 E+05 \\
0.000 E+00\end{array}$ & $2.057 E+03$ & 173. \\
\hline Time $=$ & \multicolumn{8}{|c|}{160.0 seconds. } \\
\hline Compartment & & $\begin{array}{l}\text { Upper } \\
\text { Temp. } \\
(\mathrm{K})\end{array}$ & $\begin{array}{l}\text { Lower } \\
\text { Temp. } \\
(\mathrm{K})\end{array}$ & $\begin{array}{l}\text { Inter. } \\
\text { Height } \\
(\mathrm{m})\end{array}$ & $\begin{array}{l}\text { Pyrol } \\
\text { Rate } \\
(\mathrm{kg} / \mathrm{s})\end{array}$ & $\begin{array}{l}\text { Fire } \\
\text { Size } \\
(W)\end{array}$ & $\begin{array}{l}\text { Pressure } \\
(\mathrm{Pa})\end{array}$ & $\begin{array}{l}\text { Ambient } \\
\text { Target } \\
\left(\mathrm{W} / \mathrm{m}^{\wedge} 2\right)\end{array}$ \\
\hline $\begin{array}{c}1 \\
\text { Outside }\end{array}$ & & 347.7 & 302.0 & 1.4 & $1.425 \mathrm{E}-02$ & $\begin{array}{l}3.433 E+05 \\
0.000 E+00\end{array}$ & $2.025 E+03$ & 190 \\
\hline Time $=$ & \multicolumn{8}{|c|}{170.0 seconds. } \\
\hline Compartment & & $\begin{array}{l}\text { Upper } \\
\text { Temp. } \\
(\mathrm{K})\end{array}$ & $\begin{array}{l}\text { Lower } \\
\text { Temp. } \\
(\mathrm{K})\end{array}$ & $\begin{array}{l}\text { Inter. } \\
\text { Height } \\
(\mathrm{m})\end{array}$ & $\begin{array}{l}\text { Pyrol } \\
\text { Rate } \\
(\mathrm{kg} / \mathrm{s})\end{array}$ & $\begin{array}{l}\text { Fire } \\
\text { Size } \\
\text { (W) }\end{array}$ & $\begin{array}{l}\text { Pressure } \\
(\mathrm{Pa})\end{array}$ & $\begin{array}{l}\text { Ambient } \\
\text { Target } \\
\left(\mathrm{W} / \mathrm{m}^{\wedge} 2\right)\end{array}$ \\
\hline $\begin{array}{c}1 \\
\text { Outside }\end{array}$ & & 350.0 & 301.9 & 1.3 & $1.418 \mathrm{E}-02$ & $\begin{array}{l}3.416 \mathrm{E}+05 \\
0.000 \mathrm{E}+00\end{array}$ & $1.962 \mathrm{E}+03$ & 206 . \\
\hline Time $=\quad 1$ & \multicolumn{8}{|c|}{180.0 seconds. } \\
\hline Compartment & & $\begin{array}{l}\text { Upper } \\
\text { Temp. } \\
(\mathrm{K})\end{array}$ & $\begin{array}{l}\text { Lower } \\
\text { Temp. } \\
(\mathrm{K})\end{array}$ & $\begin{array}{l}\text { Inter. } \\
\text { Height } \\
(\mathrm{m})\end{array}$ & $\begin{array}{l}\text { Pyrol } \\
\text { Rate } \\
(\mathrm{kg} / \mathrm{s})\end{array}$ & $\begin{array}{l}\text { Fire } \\
\text { Size } \\
(W)\end{array}$ & $\begin{array}{l}\text { Pressure } \\
(\mathrm{Pa})\end{array}$ & $\begin{array}{l}\text { Ambient } \\
\text { Target } \\
\left(\mathrm{W} / \mathrm{m}^{\wedge} 2\right)\end{array}$ \\
\hline $\begin{array}{c}1 \\
\text { Outside }\end{array}$ & & 352.1 & 301.9 & 1.2 & $1.411 \mathrm{E}-02$ & $\begin{array}{l}3.400 \mathrm{E}+05 \\
0.000 \mathrm{E}+00\end{array}$ & $1.878 \mathrm{E}+03$ & 222 \\
\hline Time $=$ & \multicolumn{8}{|c|}{190.0 seconds. } \\
\hline Compartment & & $\begin{array}{l}\text { Upper } \\
\text { Temp. } \\
(\mathrm{K})\end{array}$ & $\begin{array}{l}\text { Lower } \\
\text { Temp. } \\
(\mathrm{K})\end{array}$ & $\begin{array}{l}\text { Inter. } \\
\text { Height } \\
(\mathrm{m})\end{array}$ & $\begin{array}{l}\text { Pyrol } \\
\text { Rate } \\
(\mathrm{kg} / \mathrm{s})\end{array}$ & $\begin{array}{l}\text { Fire } \\
\text { Size } \\
(W)\end{array}$ & $\begin{array}{l}\text { Pressure } \\
(\mathrm{Pa})\end{array}$ & $\begin{array}{l}\text { Ambient } \\
\text { Target } \\
\left(W / m^{\wedge} 2\right)\end{array}$ \\
\hline $\begin{array}{c}1 \\
\text { Outside }\end{array}$ & & 353.8 & 301.8 & 1.2 & $1.314 \mathrm{E}-02$ & $\begin{array}{l}3.166 \mathrm{E}+05 \\
0.000 \mathrm{E}+00\end{array}$ & $1.737 \mathrm{E}+03$ & 235. \\
\hline Time $=$ & \multicolumn{8}{|c|}{200.0 seconds. } \\
\hline Compartment & & $\begin{array}{l}\text { Upper } \\
\text { Temp. } \\
(\mathrm{K})\end{array}$ & $\begin{array}{l}\text { Lower } \\
\text { Temp. } \\
(\mathrm{K})\end{array}$ & $\begin{array}{l}\text { Inter. } \\
\text { Height } \\
\text { (m) }\end{array}$ & $\begin{array}{l}\text { Pyrol } \\
\text { Rate } \\
(\mathrm{kg} / \mathrm{s})\end{array}$ & $\begin{array}{l}\text { Fire } \\
\text { Size } \\
\text { (W) }\end{array}$ & $\begin{array}{l}\text { Pressure } \\
(\mathrm{Pa})\end{array}$ & $\begin{array}{l}\text { Ambient } \\
\text { Target } \\
\left(\mathrm{W} / \mathrm{m}^{\wedge} 2\right)\end{array}$ \\
\hline $\begin{array}{c}1 \\
\text { Outside }\end{array}$ & & 355.1 & 301.7 & 1.1 & $1.217 \mathrm{E}-02$ & $\begin{array}{l}2.933 E+05 \\
0.000 E+00\end{array}$ & $1.519 \mathrm{E}+03$ & 246. \\
\hline Time $=$ & \multicolumn{8}{|c|}{210.0 seconds. } \\
\hline Compartment & & $\begin{array}{l}\text { Upper } \\
\text { Temp. } \\
(\mathrm{K})\end{array}$ & $\begin{array}{l}\text { Lower } \\
\text { Temp. } \\
(\mathrm{K})\end{array}$ & $\begin{array}{l}\text { Inter. } \\
\text { Height } \\
\text { (m) }\end{array}$ & $\begin{array}{l}\text { Pyrol } \\
\text { Rate } \\
(\mathrm{kg} / \mathrm{s})\end{array}$ & $\begin{array}{l}\text { Fire } \\
\text { Size } \\
\text { (W) }\end{array}$ & $\begin{array}{l}\text { Pressure } \\
(\mathrm{Pa})\end{array}$ & $\begin{array}{l}\text { Ambient } \\
\text { Target } \\
\left(\mathrm{W} / \mathrm{m}^{\wedge} 2\right)\end{array}$ \\
\hline$\frac{1}{\text { Outside }}$ & & 356.0 & 301.5 & 0.99 & $1.120 \mathrm{E}-02$ & $\begin{array}{l}2.700 E+05 \\
0.000 E+00\end{array}$ & $1.254 \mathrm{E}+03$ & 255. \\
\hline
\end{tabular}




\begin{tabular}{|c|c|c|c|c|c|c|c|c|}
\hline \multicolumn{2}{|l|}{ Compartment } & $\begin{array}{l}\text { Upper } \\
\text { Temp. } \\
(\mathrm{K})\end{array}$ & $\begin{array}{l}\text { Lower } \\
\text { Temp. } \\
(\mathrm{K})\end{array}$ & $\begin{array}{l}\text { Inter. } \\
\text { Height } \\
\text { (m) }\end{array}$ & $\begin{array}{l}\text { Pyrol } \\
\text { Rate } \\
(\mathrm{kg} / \mathrm{s})\end{array}$ & $\begin{array}{l}\text { Fire } \\
\text { Size } \\
\text { (W) }\end{array}$ & $\begin{array}{l}\text { Pressure } \\
(\mathrm{Pa})\end{array}$ & $\begin{array}{l}\text { Ambient } \\
\text { Target } \\
\left(\mathrm{W} / \mathrm{m}^{\wedge} 2\right)\end{array}$ \\
\hline${ }^{1}$ & & 356.5 & 301.3 & 0.93 & $1.024 \mathrm{E}-02$ & $\begin{array}{l}2.467 \mathrm{E}+05 \\
0.000 \mathrm{E}+00\end{array}$ & 968. & 262. \\
\hline Time $=$ & \multicolumn{8}{|c|}{230.0 seconds. } \\
\hline Compartment & & $\begin{array}{l}\text { Upper } \\
\text { Temp. } \\
(\mathrm{K})\end{array}$ & $\begin{array}{l}\text { Lower } \\
\text { Temp. } \\
(\mathrm{K})\end{array}$ & $\begin{array}{l}\text { Inter. } \\
\text { Height } \\
(\mathrm{m})\end{array}$ & $\begin{array}{l}\text { Pyrol } \\
\text { Rate } \\
(\mathrm{kg} / \mathrm{s})\end{array}$ & $\begin{array}{l}\text { Fire } \\
\text { Size } \\
\text { (W) }\end{array}$ & $\begin{array}{l}\text { Pressure } \\
(\mathrm{Pa})\end{array}$ & $\begin{array}{l}\text { Ambient } \\
\text { Target } \\
\left(\mathrm{W} / \mathrm{m}^{\wedge} 2\right)\end{array}$ \\
\hline $\begin{array}{c}1 \\
\text { Outside }\end{array}$ & & 356.8 & 301.1 & 0.87 & $9.267 \mathrm{E}-03$ & $\begin{array}{l}2.233 E+05 \\
0.000 E+00\end{array}$ & 682. & 266. \\
\hline Time $=$ & \multicolumn{8}{|c|}{240.0 seconds. } \\
\hline Compartment & & $\begin{array}{l}\text { Upper } \\
\text { Temp. } \\
(\mathrm{K})\end{array}$ & $\begin{array}{l}\text { Lower } \\
\text { Temp. } \\
(\mathrm{K})\end{array}$ & $\begin{array}{l}\text { Inter. } \\
\text { Height } \\
(\mathrm{m})\end{array}$ & $\begin{array}{l}\text { Pyrol } \\
\text { Rate } \\
(\mathrm{kg} / \mathrm{s})\end{array}$ & $\begin{array}{l}\text { Fire } \\
\text { Size } \\
(W)\end{array}$ & $\begin{array}{l}\text { Pressure } \\
(\mathrm{Pa})\end{array}$ & $\begin{array}{l}\text { Ambient } \\
\text { Target } \\
\left(\mathrm{W} / \mathrm{m}^{\wedge} 2\right)\end{array}$ \\
\hline $\begin{array}{c}1 \\
\text { Outside }\end{array}$ & & 356.8 & 301.0 & 0.82 & $8.299 \mathrm{E}-03$ & $\begin{array}{l}2.000 \mathrm{E}+05 \\
0.000 \mathrm{E}+00\end{array}$ & 417 & 269. \\
\hline Time $=$ & \multicolumn{8}{|c|}{250.0 seconds. } \\
\hline Compartment & & $\begin{array}{l}\text { Upper } \\
\text { Temp. } \\
(\mathrm{K})\end{array}$ & $\begin{array}{l}\text { Lower } \\
\text { Temp. } \\
(\mathrm{K})\end{array}$ & $\begin{array}{l}\text { Inter. } \\
\text { Height } \\
(\mathrm{m})\end{array}$ & $\begin{array}{l}\text { Pyrol } \\
\text { Rate } \\
(\mathrm{kg} / \mathrm{s})\end{array}$ & $\begin{array}{l}\text { Fire } \\
\text { Size } \\
(W)\end{array}$ & $\begin{array}{l}\text { Pressure } \\
(\mathrm{Pa})\end{array}$ & $\begin{array}{l}\text { Ambient } \\
\text { Target } \\
\left(\mathrm{W} / \mathrm{m}^{\wedge} 2\right)\end{array}$ \\
\hline $\begin{array}{c}1 \\
\text { Outside }\end{array}$ & & 356.8 & 300.8 & 0.78 & $7.953 E-03$ & $\begin{array}{l}1.917 \mathrm{E}+05 \\
0.000 \mathrm{E}+00\end{array}$ & 221 & 271. \\
\hline Time $=\quad 2$ & \multicolumn{8}{|c|}{260.0 seconds. } \\
\hline Compartment & & $\begin{array}{l}\text { Upper } \\
\text { Temp. } \\
(\mathrm{K})\end{array}$ & $\begin{array}{l}\text { Lower } \\
\text { Temp. } \\
(\mathrm{K})\end{array}$ & $\begin{array}{l}\text { Inter. } \\
\text { Height } \\
(\mathrm{m})\end{array}$ & $\begin{array}{l}\text { Pyrol } \\
\text { Rate } \\
(\mathrm{kg} / \mathrm{s})\end{array}$ & $\begin{array}{l}\text { Fire } \\
\text { Size } \\
\text { (W) }\end{array}$ & $\begin{array}{l}\text { Pressure } \\
(\mathrm{Pa})\end{array}$ & $\begin{array}{l}\text { Ambient } \\
\text { Target } \\
\left(\mathrm{W} / \mathrm{m}^{\wedge} 2\right)\end{array}$ \\
\hline $\begin{array}{c}1 \\
\text { Outside }\end{array}$ & & 356.7 & 300.8 & 0.74 & $7.607 \mathrm{E}-03$ & $\begin{array}{l}1.833 E+05 \\
0.000 E+00\end{array}$ & 109. & 272 . \\
\hline Time $=$ & \multicolumn{8}{|c|}{270.0 seconds. } \\
\hline Compartment & & $\begin{array}{l}\text { Upper } \\
\text { Temp. } \\
(\mathrm{K})\end{array}$ & $\begin{array}{l}\text { Lower } \\
\text { Temp. } \\
(\mathrm{K})\end{array}$ & $\begin{array}{l}\text { Inter. } \\
\text { Height } \\
(\mathrm{m})\end{array}$ & $\begin{array}{l}\text { Pyrol } \\
\text { Rate } \\
(\mathrm{kg} / \mathrm{s})\end{array}$ & $\begin{array}{l}\text { Fire } \\
\text { Size } \\
(W)\end{array}$ & $\begin{array}{l}\text { Pressure } \\
(\mathrm{Pa})\end{array}$ & $\begin{array}{l}\text { Ambient } \\
\text { Target } \\
\left(W / m^{\wedge} 2\right)\end{array}$ \\
\hline $\begin{array}{c}1 \\
\text { Outside }\end{array}$ & & 356.6 & 300.8 & 0.71 & $7.261 \mathrm{E}-03$ & $\begin{array}{l}1.750 E+05 \\
0.000 E+00\end{array}$ & 51.7 & 274 \\
\hline Time $=$ & \multicolumn{8}{|c|}{280.0 seconds. } \\
\hline Compartment & & $\begin{array}{l}\text { Upper } \\
\text { Temp. } \\
(\mathrm{K})\end{array}$ & $\begin{array}{l}\text { Lower } \\
\text { Temp. } \\
(\mathrm{K})\end{array}$ & $\begin{array}{l}\text { Inter. } \\
\text { Height } \\
\text { (m) }\end{array}$ & $\begin{array}{l}\text { Pyrol } \\
\text { Rate } \\
(\mathrm{kg} / \mathrm{s})\end{array}$ & $\begin{array}{l}\text { Fire } \\
\text { Size } \\
\text { (W) }\end{array}$ & $\begin{array}{l}\text { Pressure } \\
(\mathrm{Pa})\end{array}$ & $\begin{array}{l}\text { Ambient } \\
\text { Target } \\
\left(\mathrm{W} / \mathrm{m}^{\wedge} 2\right)\end{array}$ \\
\hline $\begin{array}{c}1 \\
\text { Outside }\end{array}$ & & 356.5 & 300.9 & 0.68 & $6.916 \mathrm{E}-03$ & $\begin{array}{l}1.667 \mathrm{E}+05 \\
0.000 \mathrm{E}+00\end{array}$ & 23.8 & 275 . \\
\hline Time $=$ & \multicolumn{8}{|c|}{290.0 seconds. } \\
\hline Compartment & & $\begin{array}{l}\text { Upper } \\
\text { Temp. } \\
(\mathrm{K})\end{array}$ & $\begin{array}{l}\text { Lower } \\
\text { Temp. } \\
(\mathrm{K})\end{array}$ & $\begin{array}{l}\text { Inter. } \\
\text { Height } \\
\text { (m) }\end{array}$ & $\begin{array}{l}\text { Pyrol } \\
\text { Rate } \\
(\mathrm{kg} / \mathrm{s})\end{array}$ & $\begin{array}{l}\text { Fire } \\
\text { Size } \\
\text { (W) }\end{array}$ & $\begin{array}{l}\text { Pressure } \\
(\mathrm{Pa})\end{array}$ & $\begin{array}{l}\text { Ambient } \\
\text { Target } \\
\left(\mathrm{W} / \mathrm{m}^{\wedge} 2\right)\end{array}$ \\
\hline$\frac{1}{\text { Outside }}$ & & 356.3 & 300.9 & 0.65 & $6.570 \mathrm{E}-03$ & $\begin{array}{l}1.583 E+05 \\
0.000 E+00\end{array}$ & 9.16 & 275 . \\
\hline
\end{tabular}




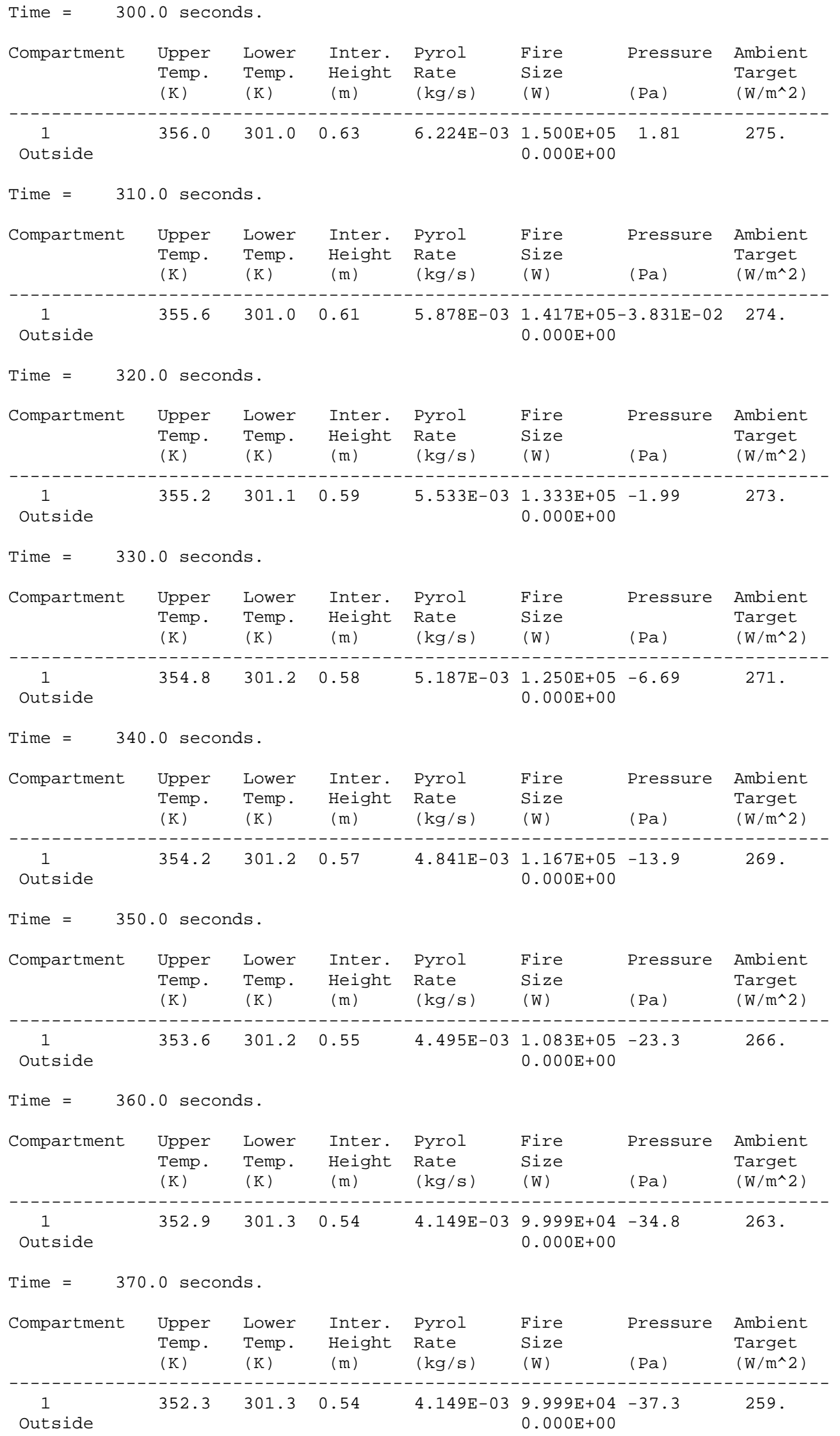




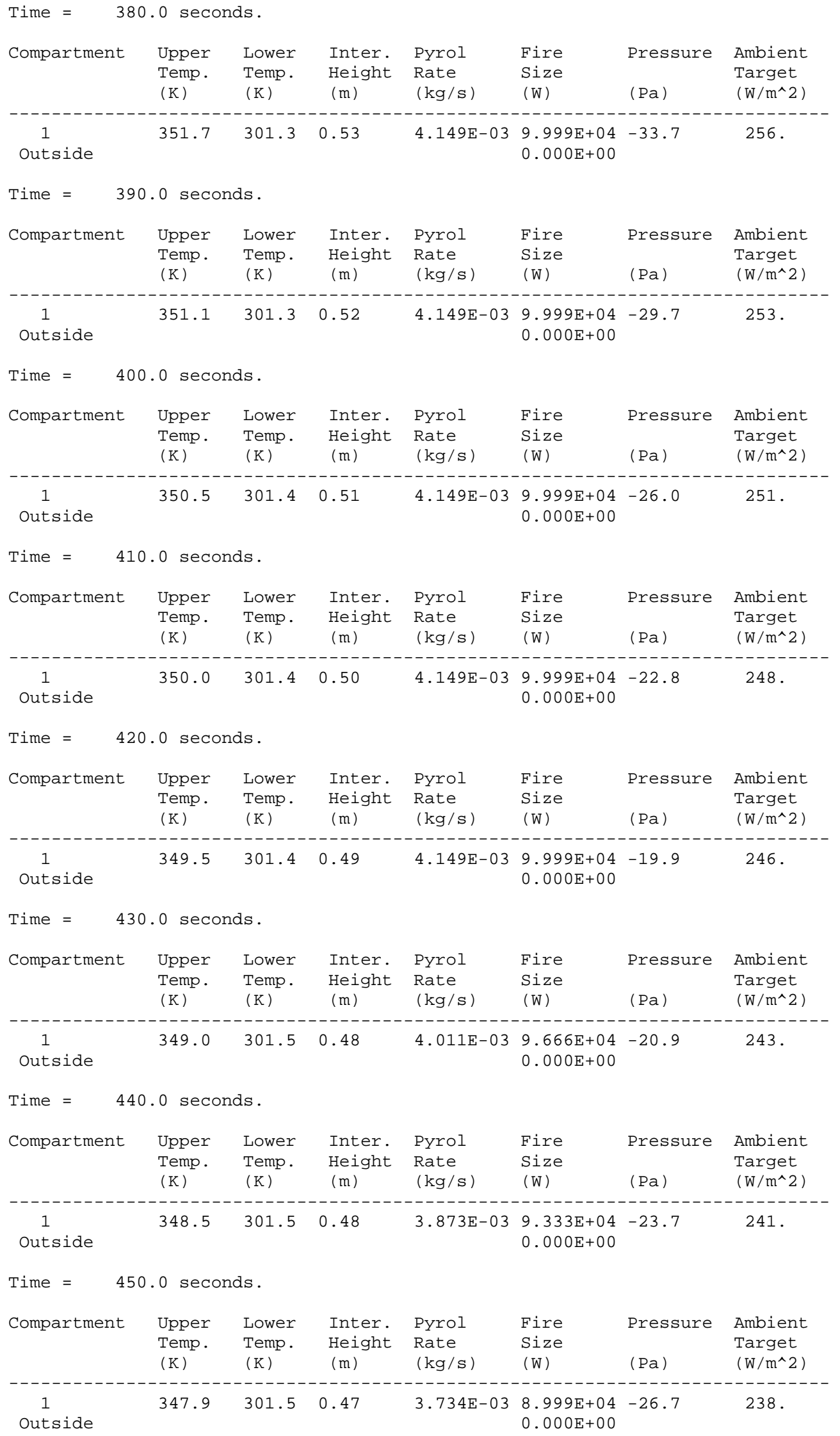




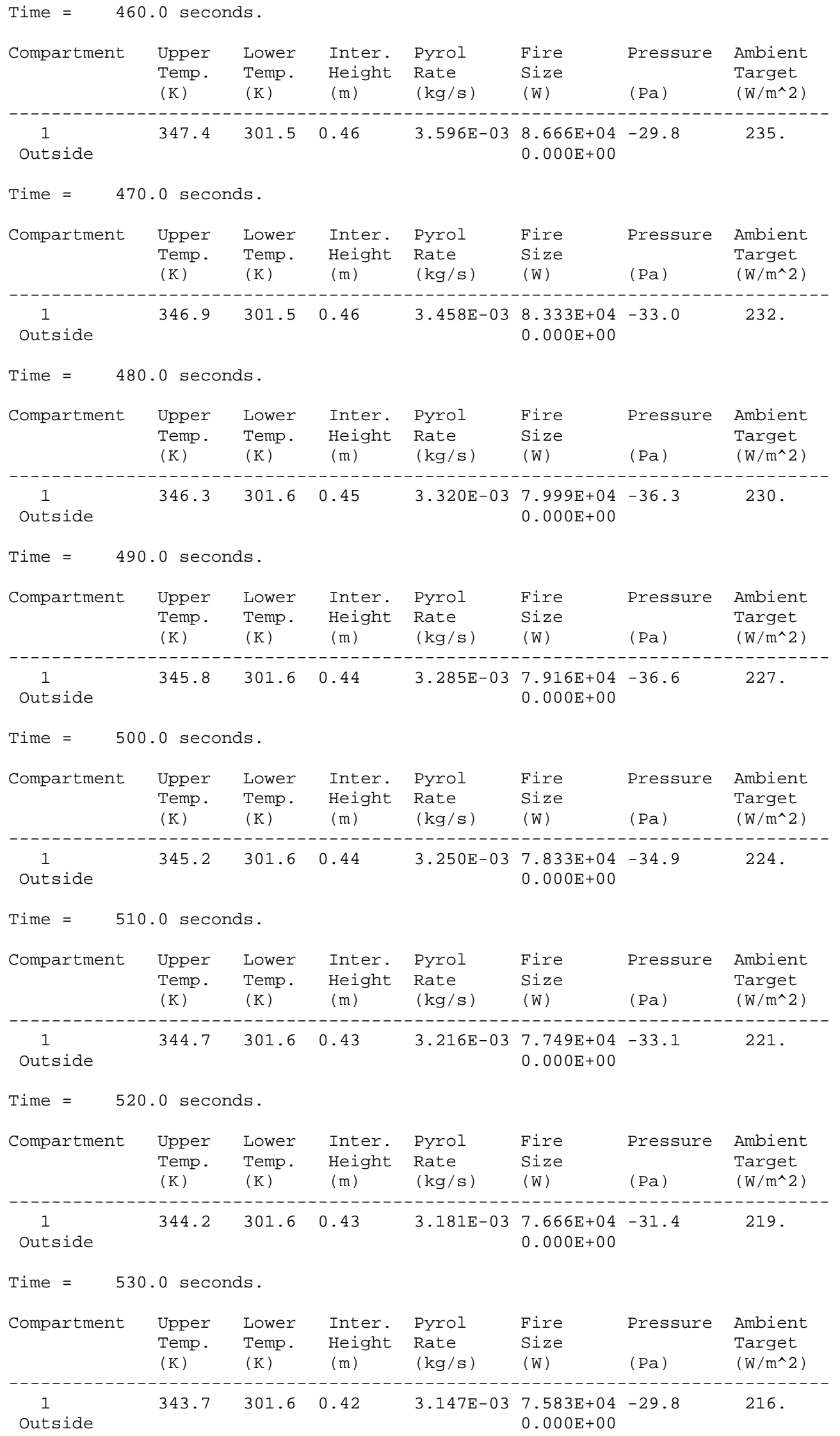




\begin{tabular}{|c|c|c|c|c|c|c|c|c|}
\hline Compartment & & $\begin{array}{l}\text { Upper } \\
\text { Temp. } \\
(\mathrm{K})\end{array}$ & $\begin{array}{l}\text { Lower } \\
\text { Temp. } \\
(\mathrm{K})\end{array}$ & $\begin{array}{l}\text { Inter. } \\
\text { Height } \\
\text { (m) }\end{array}$ & $\begin{array}{l}\text { Pyrol } \\
\text { Rate } \\
(\mathrm{kg} / \mathrm{s})\end{array}$ & $\begin{array}{l}\text { Fire } \\
\text { Size } \\
(W)\end{array}$ & $\begin{array}{l}\text { Pressure } \\
(\mathrm{Pa})\end{array}$ & $\begin{array}{l}\text { Ambient } \\
\text { Target } \\
\left(\mathrm{W} / \mathrm{m}^{\wedge} 2\right)\end{array}$ \\
\hline $\begin{array}{c}1 \\
\text { Outside }\end{array}$ & & 343.2 & 301.6 & 0.42 & $3.112 \mathrm{E}-03$ & $\begin{array}{l}7.499 E+04 \\
0.000 E+00\end{array}$ & -28.4 & 214 . \\
\hline Time $=$ & 50. & 0 seco & ds. & & & & & \\
\hline Compartment & & $\begin{array}{l}\text { Upper } \\
\text { Temp. } \\
(\mathrm{K})\end{array}$ & $\begin{array}{l}\text { Lower } \\
\text { Temp. } \\
(\mathrm{K})\end{array}$ & $\begin{array}{l}\text { Inter. } \\
\text { Height } \\
(\mathrm{m})\end{array}$ & $\begin{array}{l}\text { Pyrol } \\
\text { Rate } \\
(\mathrm{kg} / \mathrm{s})\end{array}$ & $\begin{array}{l}\text { Fire } \\
\text { Size } \\
\text { (W) }\end{array}$ & $\begin{array}{l}\text { Pressure } \\
(\mathrm{Pa})\end{array}$ & $\begin{array}{l}\text { Ambient } \\
\text { Target } \\
\left(\mathrm{W} / \mathrm{m}^{\wedge} 2\right)\end{array}$ \\
\hline $\begin{array}{c}1 \\
\text { Outside }\end{array}$ & & 342.8 & 301.6 & 0.42 & $3.285 E-03$ & $\begin{array}{l}7.916 E+04 \\
0.000 E+00\end{array}$ & $-21 \cdot 5$ & 212 . \\
\hline Time $=$ & 560. & 0 seco & ds. & & & & & \\
\hline Compartment & & $\begin{array}{l}\text { Upper } \\
\text { Temp. } \\
(\mathrm{K})\end{array}$ & $\begin{array}{l}\text { Lower } \\
\text { Temp. } \\
(\mathrm{K})\end{array}$ & $\begin{array}{l}\text { Inter. } \\
\text { Height } \\
(\mathrm{m})\end{array}$ & $\begin{array}{l}\text { Pyrol } \\
\text { Rate } \\
(\mathrm{kg} / \mathrm{s})\end{array}$ & $\begin{array}{l}\text { Fire } \\
\text { Size } \\
\text { (W) }\end{array}$ & $\begin{array}{l}\text { Pressure } \\
(\mathrm{Pa})\end{array}$ & $\begin{array}{l}\text { Ambient } \\
\text { Target } \\
\left(\mathrm{W} / \mathrm{m}^{\wedge} 2\right)\end{array}$ \\
\hline $\begin{array}{c}1 \\
\text { Outside }\end{array}$ & & 342.5 & 301.7 & 0.41 & $3.458 \mathrm{E}-03$ & $\begin{array}{l}8.333 E+04 \\
0.000 E+00\end{array}$ & $-12 \cdot 9$ & 210 \\
\hline Time $=$ & 570.0 & 0 seco & ds. & & & & & \\
\hline Compartment & & $\begin{array}{l}\text { Upper } \\
\text { Temp. } \\
(\mathrm{K})\end{array}$ & $\begin{array}{l}\text { Lower } \\
\text { Temp. } \\
(\mathrm{K})\end{array}$ & $\begin{array}{l}\text { Inter. } \\
\text { Height } \\
(\mathrm{m})\end{array}$ & $\begin{array}{l}\text { Pyrol } \\
\text { Rate } \\
(\mathrm{kg} / \mathrm{s})\end{array}$ & $\begin{array}{l}\text { Fire } \\
\text { Size } \\
\text { (W) }\end{array}$ & $\begin{array}{l}\text { Pressure } \\
(\mathrm{Pa})\end{array}$ & $\begin{array}{l}\text { Ambient } \\
\text { Target } \\
\left(\mathrm{W} / \mathrm{m}^{\wedge} 2\right)\end{array}$ \\
\hline $\begin{array}{c}1 \\
\text { Outside }\end{array}$ & & 342.2 & 301.7 & 0.40 & $3.631 E-03$ & $\begin{array}{l}8.749 E+04 \\
0.000 E+00\end{array}$ & -6.49 & 209 . \\
\hline Time $=$ & 80. & 0 seco & ds. & & & & & \\
\hline Compartment & & $\begin{array}{l}\text { Upper } \\
\text { Temp. } \\
(\mathrm{K})\end{array}$ & $\begin{array}{l}\text { Lower } \\
\text { Temp. } \\
(\mathrm{K})\end{array}$ & $\begin{array}{l}\text { Inter. } \\
\text { Height } \\
\text { (m) }\end{array}$ & $\begin{array}{l}\text { Pyrol } \\
\text { Rate } \\
(\mathrm{kg} / \mathrm{s})\end{array}$ & $\begin{array}{l}\text { Fire } \\
\text { Size } \\
\text { (W) }\end{array}$ & $\begin{array}{l}\text { Pressure } \\
(\mathrm{Pa})\end{array}$ & $\begin{array}{l}\text { Ambient } \\
\text { Target } \\
\left(\mathrm{W} / \mathrm{m}^{\wedge} 2\right)\end{array}$ \\
\hline $\begin{array}{c}1 \\
\text { Outside }\end{array}$ & & 341.9 & 301.7 & 0.39 & $3.804 \mathrm{E}-03$ & $\begin{array}{l}9.166 E+04 \\
0.000 E+00\end{array}$ & -2.40 & 208 . \\
\hline Time $=$ & 590. & $0 \sec 0$ & ds. & & & & & \\
\hline Compartment & & $\begin{array}{l}\text { Upper } \\
\text { Temp. } \\
(\mathrm{K})\end{array}$ & $\begin{array}{l}\text { Lower } \\
\text { Temp. } \\
(\mathrm{K})\end{array}$ & $\begin{array}{l}\text { Inter. } \\
\text { Height } \\
(\mathrm{m})\end{array}$ & $\begin{array}{l}\text { Pyrol } \\
\text { Rate } \\
(\mathrm{kg} / \mathrm{s})\end{array}$ & $\begin{array}{l}\text { Fire } \\
\text { Size } \\
\text { (W) }\end{array}$ & $\begin{array}{l}\text { Pressure } \\
(\mathrm{Pa})\end{array}$ & $\begin{array}{l}\text { Ambient } \\
\text { Target } \\
\left(\mathrm{W} / \mathrm{m}^{\wedge} 2\right)\end{array}$ \\
\hline $\begin{array}{c}1 \\
\text { Outside }\end{array}$ & & 341.7 & 301.7 & 0.38 & $3.976 \mathrm{E}-03$ & $\begin{array}{l}9.583 E+04- \\
0.000 E+00\end{array}$ & -0.357 & 207 . \\
\hline
\end{tabular}


Appendix 7 - Comparison of Results 
WSRC-TR-2001-00405

\begin{tabular}{|c|c|c|c|c|c|c|c|c|c|c|c|}
\hline TIME & TIME & $\begin{array}{c}\text { Upper Layer } \\
\text { Temp (1) }\end{array}$ & $\begin{array}{c}\text { Lower Layer } \\
\text { Temp (1) }\end{array}$ & $\begin{array}{c}\text { Layer Height } \\
\text { (1) }\end{array}$ & $\begin{array}{l}\text { Upper Layer } \\
\text { Volume (1) }\end{array}$ & Pressure (1) & $\begin{array}{l}\text { Ambient } \\
\text { Target (1) }\end{array}$ & $\begin{array}{c}\text { Floor Target } \\
\text { (1) }\end{array}$ & $\begin{array}{c}\text { Main Plume } \\
\text { Flow }\end{array}$ & $\begin{array}{c}\text { Main } \\
\text { Pyrolysis } \\
\text { Rate }\end{array}$ & $\begin{array}{c}\text { Main Fire } \\
\text { Size }\end{array}$ \\
\hline 0 & OK & $\mathrm{OK}$ & OK & OK & OK & OK & OK & OK & OK & OK & OK \\
\hline 10 & OK & OK & OK & OK & OK & OK & 0.0000 & 0.0000 & OK & OK & OK \\
\hline 20 & OK & $\mathrm{OK}$ & $\mathrm{OK}$ & OK & $\mathrm{OK}$ & OK & 0.0000 & 0.0000 & $\mathrm{OK}$ & OK & $\mathrm{OK}$ \\
\hline 30 & OK & $\mathrm{OK}$ & $\mathrm{OK}$ & $\mathrm{OK}$ & $\mathrm{OK}$ & $\mathrm{OK}$ & 0.0000 & 0.0000 & OK & OK & $\mathrm{OK}$ \\
\hline 40 & OK & $\mathrm{OK}$ & $\mathrm{OK}$ & OK & $\mathrm{OK}$ & $\mathrm{OK}$ & 0.0000 & 0.0001 & OK & OK & $\mathrm{OK}$ \\
\hline 50 & OK & OK & OK & OK & OK & 0.0000 & -0.0001 & 0.0001 & OK & OK & OK \\
\hline 60 & OK & $\mathrm{OK}$ & $\mathrm{OK}$ & OK & $\mathrm{OK}$ & 0.0000 & -0.0001 & 0.0001 & $\mathrm{OK}$ & OK & $\mathrm{OK}$ \\
\hline 70 & OK & OK & OK & OK & OK & 0.0000 & -0.0001 & 0.0002 & OK & OK & OK \\
\hline 80 & OK & OK & OK & OK & OK & 0.0000 & -0.0001 & 0.0002 & OK & OK & OK \\
\hline 90 & OK & OK & OK & OK & OK & 0.0000 & -0.0001 & 0.0002 & OK & OK & OK \\
\hline 100 & OK & OK & OK & OK & OK & 0.0000 & -0.0001 & 0.0002 & OK & OK & OK \\
\hline 110 & OK & $\mathrm{OK}$ & $\mathrm{OK}$ & OK & 0.0000 & 0.0000 & -0.0001 & 0.0002 & $\mathrm{OK}$ & OK & $\mathrm{OK}$ \\
\hline 120 & OK & OK & OK & OK & OK & 0.0000 & -0.0001 & 0.0002 & OK & OK & $\mathrm{OK}$ \\
\hline 130 & OK & 0.0000 & $\mathrm{OK}$ & OK & $\mathrm{OK}$ & 0.0000 & -0.0001 & 0.0002 & OK & OK & $\mathrm{OK}$ \\
\hline 140 & OK & 0.0000 & OK & 0.0000 & OK & 0.0000 & -0.0001 & 0.0001 & OK & OK & OK \\
\hline 150 & OK & $\mathrm{OK}$ & $\mathrm{OK}$ & OK & 0.0000 & -0.0001 & -0.0001 & 0.0001 & $\mathrm{OK}$ & OK & $\mathrm{OK}$ \\
\hline 160 & OK & 0.0000 & OK & 0.0000 & 0.0000 & -0.0001 & -0.0001 & 0.0001 & OK & OK & OK \\
\hline 170 & OK & 0.0000 & 0.0000 & OK & OK & -0.0001 & -0.0001 & 0.0001 & OK & OK & OK \\
\hline 180 & OK & 0.0000 & OK & 0.0000 & OK & -0.0001 & -0.0001 & 0.0001 & 0.0000 & OK & OK \\
\hline 190 & OK & 0.0000 & 0.0000 & 0.0000 & 0.0000 & -0.0001 & -0.0001 & 0.0001 & 0.0000 & $\mathrm{OK}$ & $\mathrm{OK}$ \\
\hline 200 & OK & 0.0000 & 0.0000 & 0.0000 & 0.0000 & -0.0001 & -0.0001 & 0.0000 & 0.0000 & OK & OK \\
\hline 210 & OK & 0.0000 & 0.0000 & 0.0000 & 0.0000 & -0.0001 & -0.0001 & 0.0000 & 0.0000 & OK & OK \\
\hline 220 & OK & 0.0000 & 0.0000 & 0.0000 & 0.0000 & -0.0001 & -0.0001 & 0.0000 & 0.0000 & OK & $\mathrm{OK}$ \\
\hline 230 & OK & 0.0000 & 0.0000 & 0.0000 & 0.0000 & -0.0002 & -0.0001 & 0.0000 & 0.0000 & OK & $\mathrm{OK}$ \\
\hline 240 & OK & 0.0000 & 0.0000 & 0.0000 & 0.0000 & -0.0002 & -0.0001 & 0.0000 & 0.0000 & $\mathrm{OK}$ & $\mathrm{OK}$ \\
\hline 250 & OK & 0.0000 & 0.0000 & 0.0000 & 0.0000 & -0.0003 & -0.0001 & -0.0001 & 0.0000 & OK & $\mathrm{OK}$ \\
\hline 260 & OK & 0.0000 & 0.0000 & 0.0000 & 0.0000 & -0.0003 & -0.0001 & -0.0001 & 0.0000 & OK & OK \\
\hline 270 & OK & 0.0000 & $\mathrm{OK}$ & 0.0000 & 0.0000 & -0.0001 & -0.0001 & -0.0001 & 0.0000 & $\mathrm{OK}$ & $\mathrm{OK}$ \\
\hline 280 & OK & 0.0000 & $\mathrm{OK}$ & 0.0000 & 0.0000 & 0.0001 & -0.0001 & -0.0001 & 0.0000 & OK & 0.0000 \\
\hline 290 & OK & 0.0000 & 0.0000 & 0.0000 & 0.0000 & 0.0006 & -0.0001 & -0.0001 & 0.0000 & OK & OK \\
\hline 300 & OK & 0.0000 & $\mathrm{OK}$ & 0.0000 & 0.0000 & 0.0022 & 0.0000 & -0.0001 & 0.0000 & $\mathrm{OK}$ & $\mathrm{OK}$ \\
\hline 310 & OK & 0.0000 & 0.0000 & 0.0000 & 0.0000 & -0.0156 & 0.0000 & -0.0002 & 0.0000 & OK & $\mathrm{OK}$ \\
\hline 320 & OK & 0.0000 & $\mathrm{OK}$ & 0.0000 & 0.0000 & -0.0025 & 0.0000 & -0.0002 & 0.0000 & $\mathrm{OK}$ & $\mathrm{OK}$ \\
\hline 330 & OK & 0.0000 & $\mathrm{OK}$ & 0.0000 & 0.0000 & -0.0016 & 0.0000 & -0.0002 & 0.0000 & OK & $\mathrm{OK}$ \\
\hline 340 & OK & 0.0000 & 0.0000 & 0.0000 & 0.0000 & -0.0012 & 0.0000 & -0.0002 & 0.0000 & OK & OK \\
\hline 350 & OK & 0.0000 & OK & 0.0000 & 0.0000 & -0.0010 & OK & -0.0002 & 0.0000 & OK & OK \\
\hline 360 & OK & 0.0000 & 0.0000 & 0.0000 & $\mathrm{OK}$ & -0.0009 & 0.0000 & -0.0002 & 0.0000 & OK & $\mathrm{OK}$ \\
\hline 370 & OK & 0.0000 & 0.0000 & 0.0000 & $\mathrm{OK}$ & -0.0010 & 0.0000 & -0.0002 & OK & OK & $\mathrm{OK}$ \\
\hline 380 & OK & 0.0000 & 0.0000 & OK & $\mathrm{OK}$ & -0.0011 & 0.0000 & -0.0002 & OK & OK & $\mathrm{OK}$ \\
\hline 390 & OK & 0.0000 & 0.0000 & 0.0000 & OK & -0.0013 & 0.0000 & -0.0002 & 0.0000 & OK & OK \\
\hline 400 & OK & 0.0000 & 0.0000 & 0.0000 & OK & -0.0014 & 0.0001 & -0.0002 & 0.0000 & OK & $\mathrm{OK}$ \\
\hline 410 & OK & $\mathrm{OK}$ & 0.0000 & 0.0000 & 0.0000 & -0.0015 & 0.0001 & -0.0002 & 0.0000 & OK & $\mathrm{OK}$ \\
\hline 420 & OK & $\mathrm{OK}$ & 0.0000 & 0.0000 & 0.0000 & -0.0017 & 0.0001 & -0.0001 & 0.0000 & $\mathrm{OK}$ & $\mathrm{OK}$ \\
\hline 430 & OK & 0.0000 & 0.0000 & 0.0000 & 0.0000 & -0.0016 & 0.0001 & -0.0001 & 0.0000 & OK & $\mathrm{OK}$ \\
\hline 440 & OK & 0.0000 & 0.0000 & 0.0000 & 0.0000 & -0.0015 & 0.0001 & -0.0001 & 0.0000 & OK & OK \\
\hline 450 & OK & 0.0000 & 0.0000 & 0.0000 & 0.0000 & -0.0014 & 0.0001 & -0.0001 & 0.0000 & $\mathrm{OK}$ & $\mathrm{OK}$ \\
\hline 460 & OK & 0.0000 & 0.0000 & 0.0000 & 0.0000 & -0.0013 & 0.0001 & -0.0001 & 0.0000 & OK & $\mathrm{OK}$ \\
\hline 470 & OK & 0.0000 & 0.0000 & 0.0000 & 0.0000 & -0.0013 & 0.0001 & -0.0001 & 0.0000 & OK & $\mathrm{OK}$ \\
\hline 480 & OK & 0.0000 & 0.0000 & -0.0001 & 0.0000 & -0.0012 & 0.0001 & -0.0001 & 0.0000 & OK & OK \\
\hline 490 & OK & 0.0000 & 0.0000 & -0.0001 & 0.0000 & -0.0012 & 0.0002 & -0.0001 & -0.0001 & OK & 0.0000 \\
\hline 500 & OK & 0.0000 & 0.0000 & -0.0001 & 0.0000 & -0.0012 & 0.0002 & -0.0001 & -0.0001 & $\mathrm{OK}$ & $\mathrm{OK}$ \\
\hline 510 & OK & 0.0000 & 0.0000 & -0.0001 & 0.0000 & -0.0012 & 0.0002 & -0.0001 & -0.0001 & OK & $\mathrm{OK}$ \\
\hline 520 & OK & 0.0000 & 0.0000 & -0.0001 & 0.0000 & -0.0013 & 0.0002 & -0.0001 & -0.0001 & OK & OK \\
\hline 530 & OK & 0.0000 & 0.0000 & -0.0001 & 0.0000 & -0.0013 & 0.0002 & -0.0001 & -0.0001 & OK & OK \\
\hline 540 & OK & 0.0000 & 0.0000 & -0.0001 & 0.0000 & -0.0013 & 0.0002 & 0.0000 & -0.0001 & OK & 0.0000 \\
\hline 550 & OK & 0.0000 & 0.0000 & -0.0001 & 0.0000 & -0.0015 & 0.0002 & 0.0000 & -0.0001 & OK & $\mathrm{OK}$ \\
\hline 560 & OK & 0.0000 & 0.0000 & -0.0001 & 0.0000 & -0.0020 & 0.0002 & 0.0000 & -0.0001 & OK & OK \\
\hline 570 & OK & 0.0000 & 0.0000 & -0.0001 & 0.0000 & -0.0027 & 0.0002 & 0.0000 & -0.0001 & OK & OK \\
\hline 580 & OK & 0.0000 & 0.0000 & -0.0001 & 0.0000 & -0.0042 & 0.0002 & 0.0000 & -0.0001 & OK & 0.0000 \\
\hline 590 & OK & 0.0000 & 0.0000 & -0.0001 & 0.0000 & -0.0105 & 0.0003 & 0.0000 & -0.0001 & OK & OK \\
\hline
\end{tabular}


WSRC-TR-2001-00405

\begin{tabular}{|c|c|c|c|c|c|c|c|c|c|c|c|}
\hline TIME & $\begin{array}{c}\text { Main Flame } \\
\text { Height }\end{array}$ & $\begin{array}{c}\text { Main } \\
\text { Convec. Size }\end{array}$ & $\begin{array}{c}\text { Target } \\
\text { Temperature } \\
(1)\end{array}$ & $\begin{array}{c}\text { Target Flux } \\
\text { (1) }\end{array}$ & $\begin{array}{c}\text { Target Fire } \\
\text { Rad. (1) }\end{array}$ & $\begin{array}{c}\text { Target } \\
\text { Surface Rad. } \\
(1)\end{array}$ & $\begin{array}{c}\text { Target Gas } \\
\text { Rad. (1) }\end{array}$ & $\begin{array}{c}\text { Target } \\
\text { Convec. (1) }\end{array}$ & \begin{tabular}{|c|} 
Target \\
Temperature \\
$(2)$ \\
\end{tabular} & $\begin{array}{c}\text { Target Flux } \\
\text { (2) }\end{array}$ & $\begin{array}{c}\text { Target Fire } \\
\text { Rad. (2) }\end{array}$ \\
\hline 0 & OK & OK & OK & OK & OK & OK & OK & OK & OK & OK & OK \\
\hline 10 & OK & OK & OK & OK & OK & OK & OK & OK & OK & OK & OK \\
\hline 20 & $\mathrm{OK}$ & $\mathrm{OK}$ & $\mathrm{OK}$ & OK & $\mathrm{OK}$ & OK & $\mathrm{OK}$ & $\mathrm{OK}$ & OK & OK & OK \\
\hline 30 & $\mathrm{OK}$ & $\mathrm{OK}$ & $\mathrm{OK}$ & 0.0000 & $\mathrm{OK}$ & OK & $\mathrm{OK}$ & OK & $\mathrm{OK}$ & OK & OK \\
\hline 40 & $\mathrm{OK}$ & $\mathrm{OK}$ & $\mathrm{OK}$ & 0.0000 & 0.0000 & 0.0000 & $\mathrm{OK}$ & OK & OK & OK & OK \\
\hline 50 & OK & OK & OK & 0.0000 & 0.0000 & 0.0000 & 0.0000 & OK & OK & 0.0000 & OK \\
\hline 60 & $\mathrm{OK}$ & $\mathrm{OK}$ & $\mathrm{OK}$ & 0.0000 & 0.0000 & 0.0000 & 0.0000 & OK & OK & OK & OK \\
\hline 70 & OK & OK & OK & 0.0000 & 0.0000 & 0.0000 & 0.0000 & OK & 0.0000 & 0.0000 & OK \\
\hline 80 & OK & OK & OK & 0.0000 & 0.0000 & 0.0000 & 0.0000 & 0.0000 & 0.0000 & 0.0000 & OK \\
\hline 90 & OK & OK & 0.0000 & 0.0000 & 0.0000 & 0.0000 & 0.0000 & 0.0000 & 0.0000 & 0.0000 & OK \\
\hline 100 & OK & OK & OK & 0.0000 & 0.0000 & 0.0000 & 0.0000 & 0.0000 & 0.0000 & 0.0000 & OK \\
\hline 110 & $\mathrm{OK}$ & $\mathrm{OK}$ & $\mathrm{OK}$ & 0.0000 & 0.0000 & 0.0000 & OK & $\mathrm{OK}$ & 0.0000 & 0.0000 & OK \\
\hline 120 & OK & OK & OK & 0.0000 & 0.0000 & 0.0000 & 0.0000 & 0.0000 & 0.0000 & 0.0000 & OK \\
\hline 130 & $\mathrm{OK}$ & $\mathrm{OK}$ & $\mathrm{OK}$ & 0.0000 & 0.0000 & 0.0000 & 0.0000 & 0.0000 & 0.0000 & 0.0000 & OK \\
\hline 140 & OK & OK & OK & 0.0000 & 0.0000 & 0.0000 & 0.0000 & 0.0000 & 0.0000 & 0.0000 & OK \\
\hline 150 & $\mathrm{OK}$ & $\mathrm{OK}$ & $\mathrm{OK}$ & 0.0000 & 0.0000 & 0.0000 & 0.0000 & 0.0000 & 0.0000 & 0.0000 & OK \\
\hline 160 & OK & OK & OK & 0.0000 & 0.0000 & 0.0000 & 0.0000 & 0.0000 & 0.0000 & 0.0000 & OK \\
\hline 170 & OK & OK & OK & 0.0000 & 0.0000 & 0.0000 & 0.0000 & 0.0000 & 0.0000 & 0.0000 & OK \\
\hline 180 & OK & OK & OK & 0.0000 & 0.0000 & 0.0000 & OK & 0.0000 & 0.0000 & 0.0000 & OK \\
\hline 190 & $\mathrm{OK}$ & $\mathrm{OK}$ & $\mathrm{OK}$ & 0.0000 & 0.0000 & 0.0000 & $\mathrm{OK}$ & 0.0000 & 0.0000 & 0.0000 & OK \\
\hline 200 & OK & OK & OK & 0.0000 & 0.0000 & 0.0000 & OK & 0.0000 & 0.0000 & 0.0000 & OK \\
\hline 210 & OK & $\mathrm{OK}$ & 0.0000 & 0.0000 & 0.0000 & 0.0000 & OK & 0.0000 & 0.0000 & 0.0000 & OK \\
\hline 220 & 0.0000 & OK & OK & 0.0000 & 0.0000 & 0.0000 & 0.0000 & 0.0000 & 0.0000 & 0.0000 & OK \\
\hline 230 & $\mathrm{OK}$ & $\mathrm{OK}$ & 0.0000 & 0.0000 & 0.0000 & 0.0000 & $\mathrm{OK}$ & 0.0000 & 0.0000 & 0.0000 & OK \\
\hline 240 & $\mathrm{OK}$ & $\mathrm{OK}$ & $\mathrm{OK}$ & 0.0000 & 0.0000 & 0.0000 & $\mathrm{OK}$ & 0.0000 & 0.0000 & 0.0000 & OK \\
\hline 250 & $\mathrm{OK}$ & $\mathrm{OK}$ & $\mathrm{OK}$ & 0.0000 & 0.0000 & OK & 0.0000 & 0.0000 & OK & 0.0000 & OK \\
\hline 260 & OK & OK & 0.0000 & 0.0000 & 0.0000 & 0.0000 & 0.0000 & 0.0000 & OK & 0.0000 & OK \\
\hline 270 & $\mathrm{OK}$ & $\mathrm{OK}$ & 0.0000 & 0.0000 & 0.0000 & 0.0000 & 0.0000 & 0.0000 & 0.0000 & 0.0000 & OK \\
\hline 280 & $\mathrm{OK}$ & $\mathrm{OK}$ & 0.0000 & 0.0000 & 0.0000 & 0.0000 & 0.0000 & 0.0000 & 0.0000 & 0.0000 & OK \\
\hline 290 & $\mathrm{OK}$ & OK & 0.0000 & 0.0000 & 0.0000 & 0.0000 & 0.0000 & 0.0000 & 0.0000 & 0.0000 & OK \\
\hline 300 & $\mathrm{OK}$ & $\mathrm{OK}$ & $\mathrm{OK}$ & 0.0000 & 0.0000 & 0.0000 & 0.0000 & 0.0001 & 0.0000 & 0.0000 & OK \\
\hline 310 & OK & OK & 0.0000 & 0.0000 & 0.0000 & 0.0000 & OK & 0.0000 & 0.0000 & 0.0000 & OK \\
\hline 320 & $\mathrm{OK}$ & $\mathrm{OK}$ & $\mathrm{OK}$ & 0.0000 & 0.0000 & 0.0000 & 0.0000 & 0.0000 & 0.0000 & 0.0000 & OK \\
\hline 330 & $\mathrm{OK}$ & $\mathrm{OK}$ & 0.0000 & 0.0000 & 0.0000 & 0.0000 & 0.0000 & 0.0000 & 0.0000 & 0.0000 & OK \\
\hline 340 & $\mathrm{OK}$ & $\mathrm{OK}$ & 0.0000 & 0.0000 & 0.0000 & 0.0000 & 0.0000 & 0.0000 & 0.0000 & 0.0000 & OK \\
\hline 350 & OK & OK & 0.0000 & OK & 0.0000 & 0.0000 & 0.0000 & 0.0000 & 0.0000 & 0.0000 & OK \\
\hline 360 & $\mathrm{OK}$ & $\mathrm{OK}$ & $\mathrm{OK}$ & 0.0000 & 0.0000 & 0.0000 & 0.0000 & 0.0000 & 0.0000 & 0.0000 & OK \\
\hline 370 & $\mathrm{OK}$ & $\mathrm{OK}$ & $\mathrm{OK}$ & 0.0000 & 0.0000 & 0.0000 & 0.0000 & 0.0000 & 0.0000 & 0.0000 & OK \\
\hline 380 & OK & OK & 0.0000 & OK & OK & 0.0000 & 0.0000 & OK & 0.0000 & 0.0000 & OK \\
\hline 390 & OK & OK & OK & 0.0000 & 0.0000 & 0.0000 & 0.0000 & 0.0000 & 0.0000 & 0.0000 & OK \\
\hline 400 & OK & OK & OK & 0.0000 & 0.0000 & 0.0000 & 0.0000 & 0.0000 & 0.0000 & 0.0000 & OK \\
\hline 410 & $\mathrm{OK}$ & $\mathrm{OK}$ & $\mathrm{OK}$ & 0.0000 & 0.0000 & 0.0000 & 0.0000 & 0.0000 & 0.0000 & OK & OK \\
\hline 420 & $\mathrm{OK}$ & $\mathrm{OK}$ & 0.0000 & 0.0000 & 0.0000 & 0.0000 & 0.0000 & 0.0000 & 0.0000 & 0.0000 & OK \\
\hline 430 & $\mathrm{OK}$ & $\mathrm{OK}$ & 0.0000 & 0.0000 & 0.0000 & 0.0000 & 0.0000 & 0.0000 & 0.0000 & 0.0000 & OK \\
\hline 440 & OK & OK & 0.0000 & 0.0000 & 0.0000 & 0.0000 & 0.0000 & 0.0000 & 0.0000 & 0.0000 & OK \\
\hline 450 & $\mathrm{OK}$ & $\mathrm{OK}$ & $\mathrm{OK}$ & 0.0000 & 0.0000 & 0.0000 & 0.0000 & 0.0001 & 0.0000 & 0.0000 & OK \\
\hline 460 & $\mathrm{OK}$ & $\mathrm{OK}$ & $\mathrm{OK}$ & 0.0000 & 0.0000 & 0.0000 & 0.0000 & 0.0001 & 0.0000 & 0.0000 & OK \\
\hline 470 & $\mathrm{OK}$ & $\mathrm{OK}$ & $\mathrm{OK}$ & 0.0000 & 0.0000 & 0.0000 & 0.0000 & 0.0001 & 0.0000 & 0.0000 & OK \\
\hline 480 & OK & OK & 0.0000 & 0.0000 & -0.0001 & 0.0000 & 0.0000 & 0.0001 & 0.0000 & 0.0000 & OK \\
\hline 490 & 0.0000 & OK & OK & 0.0001 & -0.0001 & 0.0000 & 0.0000 & 0.0002 & 0.0000 & 0.0000 & OK \\
\hline 500 & $\mathrm{OK}$ & $\mathrm{OK}$ & 0.0000 & 0.0000 & -0.0001 & 0.0000 & 0.0000 & 0.0000 & 0.0000 & 0.0000 & OK \\
\hline 510 & OK & OK & OK & 0.0000 & -0.0001 & 0.0000 & 0.0000 & 0.0001 & 0.0000 & 0.0000 & OK \\
\hline 520 & OK & OK & OK & 0.0000 & -0.0001 & 0.0000 & 0.0000 & 0.0001 & 0.0000 & 0.0000 & OK \\
\hline 530 & OK & OK & 0.0000 & 0.0000 & -0.0001 & 0.0000 & 0.0000 & 0.0001 & 0.0000 & 0.0000 & OK \\
\hline 540 & $\mathrm{OK}$ & $\mathrm{OK}$ & 0.0000 & 0.0001 & -0.0001 & 0.0000 & 0.0000 & 0.0001 & 0.0000 & 0.0000 & OK \\
\hline 550 & OK & OK & 0.0000 & 0.0000 & -0.0001 & 0.0000 & 0.0000 & -0.0001 & 0.0000 & 0.0000 & OK \\
\hline 560 & OK & OK & 0.0000 & 0.0000 & -0.0001 & 0.0000 & 0.0000 & OK & 0.0000 & 0.0000 & OK \\
\hline 570 & OK & 0.0000 & 0.0000 & 0.0001 & -0.0001 & OK & 0.0000 & 0.0002 & 0.0000 & 0.0001 & OK \\
\hline 580 & OK & OK & 0.0000 & 0.0001 & -0.0001 & 0.0000 & 0.0000 & 0.0001 & 0.0000 & 0.0001 & OK \\
\hline 590 & OK & OK & 0.0000 & 0.0001 & -0.0001 & OK & 0.0000 & 0.0001 & 0.0000 & 0.0001 & OK \\
\hline
\end{tabular}


WSRC-TR-2001-00405

\begin{tabular}{|c|c|c|c|c|c|c|c|c|c|c|c|}
\hline TIME & \begin{tabular}{|c|} 
Target \\
Surface Rad. \\
$(2)$
\end{tabular} & $\begin{array}{c}\text { Target Gas } \\
\text { Rad. (2) }\end{array}$ & $\begin{array}{c}\text { Target } \\
\text { Convec. (2) }\end{array}$ & Upper N2 (1) & Upper O2 (1) & $\begin{array}{c}\text { Upper CO2 } \\
\text { (1) }\end{array}$ & Upper CO (1) & $\begin{array}{c}\text { Upper HCN } \\
\text { (1) }\end{array}$ & $\begin{array}{c}\text { Upper HCL } \\
\text { (1) }\end{array}$ & $\begin{array}{c}\text { Upper TUHC } \\
\text { (1) }\end{array}$ & $\begin{array}{c}\text { Upper } \mathrm{H} 2 \mathrm{O} \\
\text { (1) }\end{array}$ \\
\hline 0 & OK & $\mathrm{OK}$ & OK & OK & OK & OK & OK & OK & OK & OK & OK \\
\hline 10 & OK & OK & -0.0001 & OK & OK & OK & OK & OK & OK & OK & OK \\
\hline 20 & OK & $\mathrm{OK}$ & -0.0002 & OK & $\mathrm{OK}$ & OK & OK & $\mathrm{OK}$ & OK & OK & $\mathrm{OK}$ \\
\hline 30 & OK & $\mathrm{OK}$ & -0.0009 & $\mathrm{OK}$ & $\mathrm{OK}$ & $\mathrm{OK}$ & $\mathrm{OK}$ & $\mathrm{OK}$ & OK & OK & $\mathrm{OK}$ \\
\hline 40 & 0.0000 & $\mathrm{OK}$ & -0.0028 & OK & $\mathrm{OK}$ & $\mathrm{OK}$ & $\mathrm{OK}$ & OK & OK & OK & $\mathrm{OK}$ \\
\hline 50 & 0.0000 & OK & -0.0073 & OK & OK & OK & OK & OK & OK & OK & OK \\
\hline 60 & 0.0000 & $\mathrm{OK}$ & -0.0226 & OK & $\mathrm{OK}$ & OK & OK & OK & OK & OK & $\mathrm{OK}$ \\
\hline 70 & 0.0000 & OK & 0.2907 & OK & OK & OK & OK & OK & OK & OK & OK \\
\hline 80 & 0.0000 & OK & 0.0381 & OK & OK & OK & OK & OK & OK & OK & OK \\
\hline 90 & 0.0000 & OK & 0.0251 & OK & OK & OK & OK & OK & OK & OK & OK \\
\hline 100 & 0.0000 & OK & 0.0202 & OK & OK & OK & OK & OK & OK & OK & OK \\
\hline 110 & 0.0000 & 0.0000 & 0.0174 & OK & $\mathrm{OK}$ & $\mathrm{OK}$ & $\mathrm{OK}$ & OK & $\mathrm{OK}$ & OK & $\mathrm{OK}$ \\
\hline 120 & 0.0000 & 0.0000 & 0.0155 & OK & OK & OK & OK & OK & OK & OK & OK \\
\hline 130 & 0.0000 & 0.0000 & 0.0148 & OK & $\mathrm{OK}$ & $\mathrm{OK}$ & $\mathrm{OK}$ & OK & $\mathrm{OK}$ & OK & $\mathrm{OK}$ \\
\hline 140 & 0.0000 & 0.0000 & 0.0174 & OK & OK & OK & OK & OK & OK & OK & OK \\
\hline 150 & 0.0000 & 0.0000 & 0.0256 & OK & $\mathrm{OK}$ & $\mathrm{OK}$ & $\mathrm{OK}$ & $\mathrm{OK}$ & OK & OK & $\mathrm{OK}$ \\
\hline 160 & 0.0000 & 0.0000 & 0.0652 & OK & OK & OK & OK & OK & OK & OK & OK \\
\hline 170 & 0.0000 & 0.0000 & -0.0743 & OK & OK & OK & OK & OK & OK & OK & OK \\
\hline 180 & 0.0000 & 0.0000 & -0.0227 & OK & OK & OK & OK & OK & OK & OK & OK \\
\hline 190 & 0.0000 & 0.0000 & -0.0108 & OK & $\mathrm{OK}$ & OK & $\mathrm{OK}$ & OK & $\mathrm{OK}$ & $\mathrm{OK}$ & $\mathrm{OK}$ \\
\hline 200 & 0.0000 & 0.0000 & -0.0059 & OK & OK & OK & OK & OK & OK & OK & OK \\
\hline 210 & 0.0000 & 0.0000 & -0.0035 & OK & OK & OK & OK & OK & $\mathrm{OK}$ & OK & OK \\
\hline 220 & 0.0000 & 0.0000 & -0.0020 & $\mathrm{OK}$ & $\mathrm{OK}$ & $\mathrm{OK}$ & $\mathrm{OK}$ & OK & $\mathrm{OK}$ & OK & $\mathrm{OK}$ \\
\hline 230 & 0.0000 & $\mathrm{OK}$ & -0.0011 & OK & $\mathrm{OK}$ & 0.0000 & $\mathrm{OK}$ & OK & OK & OK & $\mathrm{OK}$ \\
\hline 240 & 0.0000 & 0.0000 & -0.0003 & $\mathrm{OK}$ & $\mathrm{OK}$ & 0.0000 & OK & OK & OK & $\mathrm{OK}$ & $\mathrm{OK}$ \\
\hline 250 & $\mathrm{OK}$ & 0.0000 & 0.0003 & OK & OK & 0.0000 & OK & OK & OK & OK & OK \\
\hline 260 & 0.0000 & 0.0000 & 0.0009 & 0.0000 & OK & OK & OK & OK & OK & OK & OK \\
\hline 270 & 0.0000 & 0.0000 & 0.0014 & OK & $\mathrm{OK}$ & 0.0000 & OK & OK & $\mathrm{OK}$ & $\mathrm{OK}$ & $\mathrm{OK}$ \\
\hline 280 & 0.0000 & 0.0000 & 0.0021 & OK & $\mathrm{OK}$ & 0.0000 & OK & OK & OK & OK & 0.0000 \\
\hline 290 & 0.0000 & 0.0000 & 0.0027 & OK & OK & 0.0000 & OK & OK & OK & OK & OK \\
\hline 300 & 0.0000 & 0.0000 & 0.0033 & $\mathrm{OK}$ & $\mathrm{OK}$ & 0.0000 & $\mathrm{OK}$ & $\mathrm{OK}$ & OK & OK & 0.0000 \\
\hline 310 & 0.0000 & 0.0000 & 0.0039 & 0.0000 & OK & 0.0000 & OK & OK & OK & OK & 0.0000 \\
\hline 320 & 0.0000 & 0.0000 & 0.0045 & $\mathrm{OK}$ & $\mathrm{OK}$ & 0.0000 & $\mathrm{OK}$ & $\mathrm{OK}$ & OK & $\mathrm{OK}$ & 0.0000 \\
\hline 330 & 0.0000 & 0.0000 & 0.0050 & OK & $\mathrm{OK}$ & 0.0000 & OK & $\mathrm{OK}$ & OK & OK & 0.0000 \\
\hline 340 & 0.0000 & 0.0000 & 0.0056 & OK & $\mathrm{OK}$ & 0.0000 & $\mathrm{OK}$ & OK & OK & OK & 0.0000 \\
\hline 350 & 0.0001 & 0.0000 & 0.0061 & OK & OK & 0.0000 & OK & OK & OK & OK & 0.0000 \\
\hline 360 & 0.0001 & 0.0000 & 0.0066 & OK & $\mathrm{OK}$ & 0.0000 & $\mathrm{OK}$ & OK & $\mathrm{OK}$ & OK & 0.0000 \\
\hline 370 & 0.0001 & 0.0000 & 0.0070 & $\mathrm{OK}$ & $\mathrm{OK}$ & 0.0000 & OK & OK & $\mathrm{OK}$ & OK & 0.0000 \\
\hline 380 & 0.0001 & 0.0000 & 0.0074 & 0.0000 & $\mathrm{OK}$ & 0.0000 & OK & OK & $\mathrm{OK}$ & OK & 0.0000 \\
\hline 390 & 0.0001 & 0.0000 & 0.0078 & 0.0000 & OK & 0.0000 & $\mathrm{OK}$ & $\mathrm{OK}$ & $\mathrm{OK}$ & $\mathrm{OK}$ & 0.0000 \\
\hline 400 & 0.0001 & 0.0000 & 0.0080 & $\mathrm{OK}$ & OK & 0.0000 & OK & OK & OK & OK & 0.0000 \\
\hline 410 & 0.0001 & 0.0000 & 0.0082 & OK & 0.0000 & 0.0000 & $\mathrm{OK}$ & OK & OK & OK & 0.0000 \\
\hline 420 & 0.0001 & 0.0000 & 0.0083 & $\mathrm{OK}$ & $\mathrm{OK}$ & 0.0000 & OK & OK & OK & $\mathrm{OK}$ & 0.0000 \\
\hline 430 & 0.0001 & 0.0000 & 0.0083 & OK & OK & 0.0000 & OK & OK & OK & OK & 0.0000 \\
\hline 440 & 0.0001 & 0.0000 & 0.0082 & OK & OK & 0.0000 & OK & OK & OK & OK & 0.0000 \\
\hline 450 & 0.0001 & 0.0000 & 0.0081 & 0.0000 & $\mathrm{OK}$ & 0.0000 & OK & OK & $\mathrm{OK}$ & $\mathrm{OK}$ & 0.0000 \\
\hline 460 & 0.0000 & $\mathrm{OK}$ & 0.0081 & $\mathrm{OK}$ & $\mathrm{OK}$ & 0.0000 & OK & $\mathrm{OK}$ & $\mathrm{OK}$ & OK & 0.0000 \\
\hline 470 & 0.0000 & $\mathrm{OK}$ & 0.0080 & OK & $\mathrm{OK}$ & 0.0000 & $\mathrm{OK}$ & OK & $\mathrm{OK}$ & OK & 0.0000 \\
\hline 480 & 0.0000 & OK & 0.0079 & OK & OK & 0.0000 & OK & OK & OK & OK & 0.0000 \\
\hline 490 & 0.0000 & OK & 0.0077 & OK & OK & 0.0000 & OK & OK & OK & OK & 0.0000 \\
\hline 500 & 0.0000 & $\mathrm{OK}$ & 0.0076 & $\mathrm{OK}$ & $\mathrm{OK}$ & 0.0000 & $\mathrm{OK}$ & $\mathrm{OK}$ & OK & $\mathrm{OK}$ & 0.0000 \\
\hline 510 & 0.0000 & OK & 0.0075 & OK & OK & 0.0000 & OK & OK & OK & OK & 0.0000 \\
\hline 520 & 0.0000 & OK & 0.0074 & OK & OK & 0.0000 & OK & OK & OK & OK & 0.0000 \\
\hline 530 & 0.0000 & 0.0000 & 0.0072 & OK & OK & 0.0000 & OK & OK & OK & OK & 0.0000 \\
\hline 540 & 0.0000 & 0.0000 & 0.0070 & OK & $\mathrm{OK}$ & 0.0000 & $\mathrm{OK}$ & OK & $\mathrm{OK}$ & OK & 0.0000 \\
\hline 550 & 0.0000 & $\mathrm{OK}$ & 0.0067 & $\mathrm{OK}$ & $\mathrm{OK}$ & 0.0000 & $\mathrm{OK}$ & OK & $\mathrm{OK}$ & OK & 0.0000 \\
\hline 560 & 0.0000 & 0.0000 & 0.0065 & 0.0000 & OK & 0.0000 & OK & OK & OK & OK & 0.0000 \\
\hline 570 & 0.0000 & OK & 0.0061 & OK & OK & 0.0000 & OK & OK & OK & $\mathrm{OK}$ & 0.0000 \\
\hline 580 & 0.0000 & 0.0000 & 0.0056 & OK & OK & 0.0000 & OK & OK & OK & OK & 0.0000 \\
\hline 590 & 0.0000 & 0.0000 & 0.0050 & OK & OK & 0.0000 & OK & OK & OK & OK & 0.0000 \\
\hline
\end{tabular}


WSRC-TR-2001-00405

\begin{tabular}{|c|c|c|c|c|c|c|c|c|c|c|c|}
\hline TIME & Upper OD (1) & $\mathrm{HCl} \mathrm{c}(1)$ & $\mathrm{HCl}$ uw (1) & $\mathrm{HCl} \mathrm{Iw} \mathrm{(1)}$ & $\mathrm{HCl} f(1)$ & Lower N2 (1) & Lower O2 (1) & $\begin{array}{c}\text { Lower CO2 } \\
\text { (1) }\end{array}$ & Lower CO (1) & $\begin{array}{c}\text { Lower HCN } \\
\text { (1) }\end{array}$ & $\begin{array}{c}\text { Lower HCL } \\
\text { (1) }\end{array}$ \\
\hline 0 & $\mathrm{OK}$ & $\mathrm{OK}$ & OK & OK & $\mathrm{OK}$ & $\mathrm{OK}$ & $\mathrm{OK}$ & OK & OK & OK & $\mathrm{OK}$ \\
\hline 10 & $\mathrm{OK}$ & $\mathrm{OK}$ & $\mathrm{OK}$ & OK & $\mathrm{OK}$ & OK & $\mathrm{OK}$ & OK & OK & $\mathrm{OK}$ & OK \\
\hline 20 & $\mathrm{OK}$ & $\mathrm{OK}$ & $\mathrm{OK}$ & OK & $\mathrm{OK}$ & OK & $\mathrm{OK}$ & OK & $\mathrm{OK}$ & OK & OK \\
\hline 30 & OK & $\mathrm{OK}$ & OK & OK & OK & OK & OK & OK & $\mathrm{OK}$ & OK & OK \\
\hline 40 & $\mathrm{OK}$ & $\mathrm{OK}$ & $\mathrm{OK}$ & $\mathrm{OK}$ & $\mathrm{OK}$ & $\mathrm{OK}$ & $\mathrm{OK}$ & $\mathrm{OK}$ & OK & $\mathrm{OK}$ & $\mathrm{OK}$ \\
\hline 50 & OK & OK & $\mathrm{OK}$ & OK & OK & OK & OK & OK & OK & OK & OK \\
\hline 60 & $\mathrm{OK}$ & $\mathrm{OK}$ & $\mathrm{OK}$ & $\mathrm{OK}$ & $\mathrm{OK}$ & $\mathrm{OK}$ & $\mathrm{OK}$ & $\mathrm{OK}$ & $\mathrm{OK}$ & $\mathrm{OK}$ & $\mathrm{OK}$ \\
\hline 70 & OK & OK & OK & OK & OK & OK & OK & OK & OK & OK & OK \\
\hline 80 & OK & $\mathrm{OK}$ & OK & OK & $\mathrm{OK}$ & $\mathrm{OK}$ & $\mathrm{OK}$ & $\mathrm{OK}$ & OK & OK & OK \\
\hline 90 & OK & $\mathrm{OK}$ & OK & OK & $\mathrm{OK}$ & OK & $\mathrm{OK}$ & OK & $\mathrm{OK}$ & OK & $\mathrm{OK}$ \\
\hline 100 & $\mathrm{OK}$ & $\mathrm{OK}$ & OK & OK & OK & $\mathrm{OK}$ & OK & OK & OK & OK & OK \\
\hline 110 & OK & $\mathrm{OK}$ & OK & OK & $\mathrm{OK}$ & OK & OK & OK & OK & OK & OK \\
\hline 120 & OK & OK & OK & OK & OK & OK & OK & OK & OK & OK & OK \\
\hline 130 & $\mathrm{OK}$ & $\mathrm{OK}$ & OK & OK & OK & OK & OK & OK & OK & OK & OK \\
\hline 140 & OK & OK & OK & OK & OK & OK & OK & OK & OK & OK & OK \\
\hline 150 & OK & $\mathrm{OK}$ & OK & OK & OK & OK & OK & OK & OK & OK & OK \\
\hline 160 & OK & OK & OK & OK & OK & OK & OK & OK & OK & OK & OK \\
\hline 170 & OK & OK & OK & OK & OK & OK & OK & OK & OK & OK & OK \\
\hline 180 & OK & $\mathrm{OK}$ & OK & OK & $\mathrm{OK}$ & OK & $\mathrm{OK}$ & OK & OK & OK & OK \\
\hline 190 & OK & $\mathrm{OK}$ & OK & OK & OK & OK & OK & OK & OK & OK & OK \\
\hline 200 & OK & $\mathrm{OK}$ & OK & OK & $\mathrm{OK}$ & OK & $\mathrm{OK}$ & OK & OK & OK & OK \\
\hline 210 & OK & OK & OK & OK & OK & OK & OK & OK & OK & OK & OK \\
\hline 220 & $\mathrm{OK}$ & $\mathrm{OK}$ & $\mathrm{OK}$ & OK & OK & OK & OK & OK & OK & OK & OK \\
\hline 230 & OK & OK & OK & OK & OK & OK & OK & OK & OK & OK & OK \\
\hline 240 & $\mathrm{OK}$ & $\mathrm{OK}$ & $\mathrm{OK}$ & OK & $\mathrm{OK}$ & $\mathrm{OK}$ & $\mathrm{OK}$ & OK & OK & OK & OK \\
\hline 250 & OK & OK & OK & OK & OK & OK & OK & OK & OK & OK & OK \\
\hline 260 & OK & OK & OK & OK & OK & OK & 0.0000 & OK & OK & OK & OK \\
\hline 270 & OK & $\mathrm{OK}$ & OK & OK & OK & OK & OK & OK & OK & OK & OK \\
\hline 280 & OK & $\mathrm{OK}$ & OK & OK & OK & $\mathrm{OK}$ & OK & OK & OK & OK & OK \\
\hline 290 & OK & $\mathrm{OK}$ & OK & OK & $\mathrm{OK}$ & OK & OK & OK & OK & OK & OK \\
\hline 300 & OK & OK & OK & OK & OK & 0.0000 & 0.0000 & OK & OK & OK & OK \\
\hline 310 & OK & $\mathrm{OK}$ & OK & OK & OK & OK & OK & OK & OK & OK & OK \\
\hline 320 & OK & $\mathrm{OK}$ & OK & OK & OK & OK & OK & OK & OK & OK & OK \\
\hline 330 & $\mathrm{OK}$ & OK & OK & OK & OK & OK & OK & OK & OK & OK & OK \\
\hline 340 & OK & OK & OK & OK & OK & 0.0000 & OK & OK & OK & OK & OK \\
\hline 350 & $\mathrm{OK}$ & $\mathrm{OK}$ & $\mathrm{OK}$ & OK & $\mathrm{OK}$ & OK & OK & OK & OK & OK & OK \\
\hline 360 & $\mathrm{OK}$ & $\mathrm{OK}$ & $\mathrm{OK}$ & OK & $\mathrm{OK}$ & OK & $\mathrm{OK}$ & OK & OK & OK & OK \\
\hline 370 & $\mathrm{OK}$ & $\mathrm{OK}$ & $\mathrm{OK}$ & OK & $\mathrm{OK}$ & 0.0000 & $\mathrm{OK}$ & OK & $\mathrm{OK}$ & OK & OK \\
\hline 380 & $\mathrm{OK}$ & $\mathrm{OK}$ & $\mathrm{OK}$ & OK & $\mathrm{OK}$ & 0.0000 & OK & OK & OK & OK & OK \\
\hline 390 & OK & $\mathrm{OK}$ & OK & OK & $\mathrm{OK}$ & 0.0000 & $\mathrm{OK}$ & OK & $\mathrm{OK}$ & OK & OK \\
\hline 400 & OK & OK & OK & OK & OK & 0.0000 & OK & OK & OK & OK & OK \\
\hline 410 & $\mathrm{OK}$ & $\mathrm{OK}$ & $\mathrm{OK}$ & OK & $\mathrm{OK}$ & OK & OK & OK & OK & OK & OK \\
\hline 420 & OK & $\mathrm{OK}$ & $\mathrm{OK}$ & OK & OK & OK & OK & OK & OK & OK & OK \\
\hline 430 & $\mathrm{OK}$ & $\mathrm{OK}$ & $\mathrm{OK}$ & $\mathrm{OK}$ & $\mathrm{OK}$ & $\mathrm{OK}$ & $\mathrm{OK}$ & $\mathrm{OK}$ & OK & $\mathrm{OK}$ & OK \\
\hline 440 & $\mathrm{OK}$ & $\mathrm{OK}$ & $\mathrm{OK}$ & OK & $\mathrm{OK}$ & OK & 0.0000 & OK & OK & OK & OK \\
\hline 450 & OK & OK & OK & OK & OK & 0.0000 & OK & OK & OK & OK & OK \\
\hline 460 & $\mathrm{OK}$ & $\mathrm{OK}$ & $\mathrm{OK}$ & OK & $\mathrm{OK}$ & 0.0000 & 0.0000 & OK & OK & $\mathrm{OK}$ & $\mathrm{OK}$ \\
\hline 470 & $\mathrm{OK}$ & $\mathrm{OK}$ & OK & OK & $\mathrm{OK}$ & 0.0000 & 0.0000 & OK & OK & OK & OK \\
\hline 480 & $\mathrm{OK}$ & $\mathrm{OK}$ & $\mathrm{OK}$ & OK & $\mathrm{OK}$ & 0.0000 & $\mathrm{OK}$ & $\mathrm{OK}$ & $\mathrm{OK}$ & $\mathrm{OK}$ & $\mathrm{OK}$ \\
\hline 490 & $\mathrm{OK}$ & $\mathrm{OK}$ & OK & OK & $\mathrm{OK}$ & 0.0000 & 0.0000 & OK & OK & OK & OK \\
\hline 500 & $\mathrm{OK}$ & $\mathrm{OK}$ & $\mathrm{OK}$ & OK & $\mathrm{OK}$ & 0.0000 & OK & OK & OK & OK & OK \\
\hline 510 & OK & OK & $\mathrm{OK}$ & OK & OK & 0.0000 & 0.0000 & OK & OK & OK & OK \\
\hline 520 & $\mathrm{OK}$ & $\mathrm{OK}$ & $\mathrm{OK}$ & OK & $\mathrm{OK}$ & 0.0000 & $\mathrm{OK}$ & $\mathrm{OK}$ & OK & $\mathrm{OK}$ & OK \\
\hline 530 & $\mathrm{OK}$ & $\mathrm{OK}$ & $\mathrm{OK}$ & OK & $\mathrm{OK}$ & 0.0000 & 0.0000 & OK & OK & OK & OK \\
\hline 540 & $\mathrm{OK}$ & $\mathrm{OK}$ & $\mathrm{OK}$ & OK & $\mathrm{OK}$ & 0.0000 & $\mathrm{OK}$ & OK & OK & OK & OK \\
\hline 550 & $\mathrm{OK}$ & $\mathrm{OK}$ & $\mathrm{OK}$ & OK & $\mathrm{OK}$ & OK & 0.0000 & OK & $\mathrm{OK}$ & OK & OK \\
\hline 560 & $\mathrm{OK}$ & $\mathrm{OK}$ & $\mathrm{OK}$ & OK & $\mathrm{OK}$ & OK & 0.0000 & OK & OK & OK & OK \\
\hline 570 & $\mathrm{OK}$ & OK & $\mathrm{OK}$ & $\mathrm{OK}$ & $\mathrm{OK}$ & 0.0000 & 0.0000 & $\mathrm{OK}$ & OK & OK & OK \\
\hline 580 & $\mathrm{OK}$ & $\mathrm{OK}$ & $\mathrm{OK}$ & OK & $\mathrm{OK}$ & 0.0000 & 0.0000 & OK & OK & OK & OK \\
\hline 590 & OK & OK & OK & OK & OK & 0.0000 & OK & OK & OK & OK & OK \\
\hline
\end{tabular}


WSRC-TR-2001-00405

\begin{tabular}{|c|c|c|c|c|c|c|c|c|c|c|c|}
\hline TIME & $\begin{array}{c}\text { Lower TUHC } \\
\text { (1) }\end{array}$ & $\begin{array}{c}\text { Lower } \mathrm{H} 2 \mathrm{O} \\
\text { (1) }\end{array}$ & Lower OD (1) & $\mathrm{HCl}$ c (1) & $\mathrm{HCl}$ uw (1) & $\mathrm{HCl} \mathrm{Iw} \mathrm{(1)}$ & $\mathrm{HCl} f(1)$ & $\begin{array}{l}\text { Upper Inflow } \\
\text { 1-Outside (1) }\end{array}$ & $\begin{array}{c}\text { Upper } \\
\text { Outflow 1- } \\
\text { Outside (1) }\end{array}$ & $\begin{array}{l}\text { Lower Inflow } \\
\text { 1-Outside (1) }\end{array}$ & $\begin{array}{c}\text { Lower } \\
\text { Outflow 1- } \\
\text { Outside (1) }\end{array}$ \\
\hline 0 & OK & OK & OK & OK & OK & OK & OK & OK & OK & OK & OK \\
\hline 10 & OK & OK & OK & OK & OK & OK & OK & OK & OK & OK & OK \\
\hline 20 & $\mathrm{OK}$ & $\mathrm{OK}$ & $\mathrm{OK}$ & OK & $\mathrm{OK}$ & OK & $\mathrm{OK}$ & $\mathrm{OK}$ & OK & OK & OK \\
\hline 30 & $\mathrm{OK}$ & $\mathrm{OK}$ & $\mathrm{OK}$ & OK & $\mathrm{OK}$ & OK & $\mathrm{OK}$ & OK & $\mathrm{OK}$ & OK & $\mathrm{OK}$ \\
\hline 40 & $\mathrm{OK}$ & OK & $\mathrm{OK}$ & OK & $\mathrm{OK}$ & OK & $\mathrm{OK}$ & OK & OK & OK & 0.0000 \\
\hline 50 & OK & OK & OK & OK & OK & OK & OK & OK & OK & OK & 0.0000 \\
\hline 60 & $\mathrm{OK}$ & $\mathrm{OK}$ & $\mathrm{OK}$ & OK & $\mathrm{OK}$ & OK & $\mathrm{OK}$ & OK & OK & OK & 0.0000 \\
\hline 70 & OK & OK & OK & OK & OK & OK & OK & OK & OK & OK & 0.0000 \\
\hline 80 & OK & OK & OK & OK & OK & OK & OK & OK & OK & OK & 0.0000 \\
\hline 90 & OK & OK & OK & OK & OK & OK & OK & OK & OK & OK & 0.0000 \\
\hline 100 & OK & OK & OK & OK & OK & OK & OK & OK & OK & OK & 0.0000 \\
\hline 110 & $\mathrm{OK}$ & $\mathrm{OK}$ & $\mathrm{OK}$ & OK & $\mathrm{OK}$ & $\mathrm{OK}$ & OK & $\mathrm{OK}$ & OK & OK & 0.0000 \\
\hline 120 & OK & OK & OK & OK & OK & OK & OK & OK & OK & OK & 0.0000 \\
\hline 130 & $\mathrm{OK}$ & OK & $\mathrm{OK}$ & OK & $\mathrm{OK}$ & $\mathrm{OK}$ & $\mathrm{OK}$ & OK & OK & OK & 0.0000 \\
\hline 140 & OK & OK & OK & OK & OK & OK & OK & OK & OK & OK & 0.0000 \\
\hline 150 & $\mathrm{OK}$ & $\mathrm{OK}$ & $\mathrm{OK}$ & OK & $\mathrm{OK}$ & OK & $\mathrm{OK}$ & OK & OK & OK & 0.0000 \\
\hline 160 & OK & OK & OK & OK & OK & OK & OK & OK & OK & OK & 0.0000 \\
\hline 170 & OK & OK & OK & OK & OK & OK & OK & OK & OK & OK & 0.0000 \\
\hline 180 & OK & OK & OK & OK & OK & OK & OK & OK & OK & OK & 0.0000 \\
\hline 190 & $\mathrm{OK}$ & $\mathrm{OK}$ & $\mathrm{OK}$ & OK & $\mathrm{OK}$ & $\mathrm{OK}$ & $\mathrm{OK}$ & OK & OK & OK & 0.0000 \\
\hline 200 & OK & OK & OK & OK & OK & OK & OK & OK & OK & OK & -0.0001 \\
\hline 210 & OK & OK & OK & OK & OK & OK & OK & OK & OK & OK & -0.0001 \\
\hline 220 & $\mathrm{OK}$ & OK & $\mathrm{OK}$ & OK & $\mathrm{OK}$ & OK & $\mathrm{OK}$ & OK & OK & OK & -0.0001 \\
\hline 230 & $\mathrm{OK}$ & $\mathrm{OK}$ & $\mathrm{OK}$ & OK & $\mathrm{OK}$ & $\mathrm{OK}$ & $\mathrm{OK}$ & $\mathrm{OK}$ & OK & OK & -0.0001 \\
\hline 240 & $\mathrm{OK}$ & $\mathrm{OK}$ & $\mathrm{OK}$ & OK & $\mathrm{OK}$ & OK & $\mathrm{OK}$ & OK & $\mathrm{OK}$ & OK & -0.0001 \\
\hline 250 & OK & OK & OK & OK & OK & OK & OK & OK & OK & OK & -0.0001 \\
\hline 260 & OK & OK & OK & OK & OK & OK & OK & OK & OK & OK & -0.0001 \\
\hline 270 & $\mathrm{OK}$ & $\mathrm{OK}$ & $\mathrm{OK}$ & OK & $\mathrm{OK}$ & OK & $\mathrm{OK}$ & OK & OK & $\mathrm{OK}$ & -0.0001 \\
\hline 280 & $\mathrm{OK}$ & $\mathrm{OK}$ & $\mathrm{OK}$ & OK & $\mathrm{OK}$ & OK & OK & OK & OK & OK & 0.0001 \\
\hline 290 & $\mathrm{OK}$ & OK & $\mathrm{OK}$ & OK & $\mathrm{OK}$ & OK & $\mathrm{OK}$ & OK & OK & OK & 0.0003 \\
\hline 300 & OK & OK & $\mathrm{OK}$ & $\mathrm{OK}$ & $\mathrm{OK}$ & $\mathrm{OK}$ & $\mathrm{OK}$ & $\mathrm{OK}$ & OK & OK & 0.0011 \\
\hline 310 & OK & OK & OK & OK & OK & OK & OK & OK & OK & -0.0078 & OK \\
\hline 320 & $\mathrm{OK}$ & 0.0000 & $\mathrm{OK}$ & $\mathrm{OK}$ & $\mathrm{OK}$ & $\mathrm{OK}$ & $\mathrm{OK}$ & OK & $\mathrm{OK}$ & -0.0013 & OK \\
\hline 330 & $\mathrm{OK}$ & 0.0000 & $\mathrm{OK}$ & OK & $\mathrm{OK}$ & OK & $\mathrm{OK}$ & OK & OK & -0.0008 & OK \\
\hline 340 & OK & 0.0000 & OK & OK & OK & OK & OK & OK & OK & -0.0006 & OK \\
\hline 350 & OK & 0.0000 & OK & OK & OK & OK & OK & OK & OK & -0.0005 & OK \\
\hline 360 & $\mathrm{OK}$ & 0.0000 & $\mathrm{OK}$ & OK & $\mathrm{OK}$ & $\mathrm{OK}$ & $\mathrm{OK}$ & $\mathrm{OK}$ & OK & -0.0004 & OK \\
\hline 370 & $\mathrm{OK}$ & 0.0000 & $\mathrm{OK}$ & OK & $\mathrm{OK}$ & OK & OK & OK & $\mathrm{OK}$ & -0.0005 & OK \\
\hline 380 & $\mathrm{OK}$ & 0.0000 & $\mathrm{OK}$ & OK & $\mathrm{OK}$ & OK & $\mathrm{OK}$ & OK & OK & -0.0006 & OK \\
\hline 390 & $\mathrm{OK}$ & 0.0000 & OK & OK & OK & $\mathrm{OK}$ & $\mathrm{OK}$ & $\mathrm{OK}$ & OK & -0.0006 & OK \\
\hline 400 & OK & 0.0000 & OK & OK & OK & OK & OK & OK & OK & -0.0007 & OK \\
\hline 410 & $\mathrm{OK}$ & 0.0000 & $\mathrm{OK}$ & OK & $\mathrm{OK}$ & $\mathrm{OK}$ & $\mathrm{OK}$ & $\mathrm{OK}$ & OK & -0.0008 & OK \\
\hline 420 & $\mathrm{OK}$ & 0.0001 & $\mathrm{OK}$ & OK & $\mathrm{OK}$ & OK & $\mathrm{OK}$ & OK & $\mathrm{OK}$ & -0.0008 & OK \\
\hline 430 & OK & 0.0001 & OK & OK & OK & OK & OK & OK & OK & -0.0008 & OK \\
\hline 440 & OK & 0.0001 & OK & OK & OK & OK & OK & OK & OK & -0.0007 & OK \\
\hline 450 & $\mathrm{OK}$ & 0.0001 & $\mathrm{OK}$ & OK & $\mathrm{OK}$ & OK & $\mathrm{OK}$ & OK & OK & -0.0007 & OK \\
\hline 460 & $\mathrm{OK}$ & 0.0001 & $\mathrm{OK}$ & OK & $\mathrm{OK}$ & OK & $\mathrm{OK}$ & OK & OK & -0.0007 & OK \\
\hline 470 & $\mathrm{OK}$ & 0.0001 & $\mathrm{OK}$ & OK & $\mathrm{OK}$ & OK & $\mathrm{OK}$ & OK & OK & -0.0006 & OK \\
\hline 480 & OK & 0.0001 & OK & OK & OK & OK & OK & OK & OK & -0.0006 & OK \\
\hline 490 & OK & 0.0001 & OK & OK & OK & OK & OK & OK & OK & -0.0006 & OK \\
\hline 500 & $\mathrm{OK}$ & 0.0001 & $\mathrm{OK}$ & $\mathrm{OK}$ & $\mathrm{OK}$ & $\mathrm{OK}$ & $\mathrm{OK}$ & OK & $\mathrm{OK}$ & -0.0006 & OK \\
\hline 510 & OK & 0.0001 & OK & OK & OK & OK & OK & OK & OK & -0.0006 & OK \\
\hline 520 & OK & 0.0001 & OK & OK & OK & OK & OK & OK & OK & -0.0006 & OK \\
\hline 530 & OK & 0.0001 & OK & OK & OK & OK & OK & OK & OK & -0.0006 & OK \\
\hline 540 & $\mathrm{OK}$ & 0.0001 & $\mathrm{OK}$ & OK & $\mathrm{OK}$ & $\mathrm{OK}$ & $\mathrm{OK}$ & $\mathrm{OK}$ & OK & -0.0006 & OK \\
\hline 550 & OK & 0.0001 & $\mathrm{OK}$ & $\mathrm{OK}$ & $\mathrm{OK}$ & OK & OK & OK & OK & -0.0008 & OK \\
\hline 560 & OK & 0.0001 & $\mathrm{OK}$ & OK & $\mathrm{OK}$ & OK & OK & OK & OK & -0.0010 & OK \\
\hline 570 & OK & 0.0001 & OK & OK & OK & OK & OK & OK & OK & -0.0013 & OK \\
\hline 580 & OK & 0.0001 & OK & OK & OK & OK & OK & OK & OK & -0.0021 & OK \\
\hline 590 & OK & 0.0001 & OK & OK & OK & OK & OK & OK & OK & -0.0053 & OK \\
\hline
\end{tabular}


Appendix 8 - Comparison of Parameters with Significant Differences 


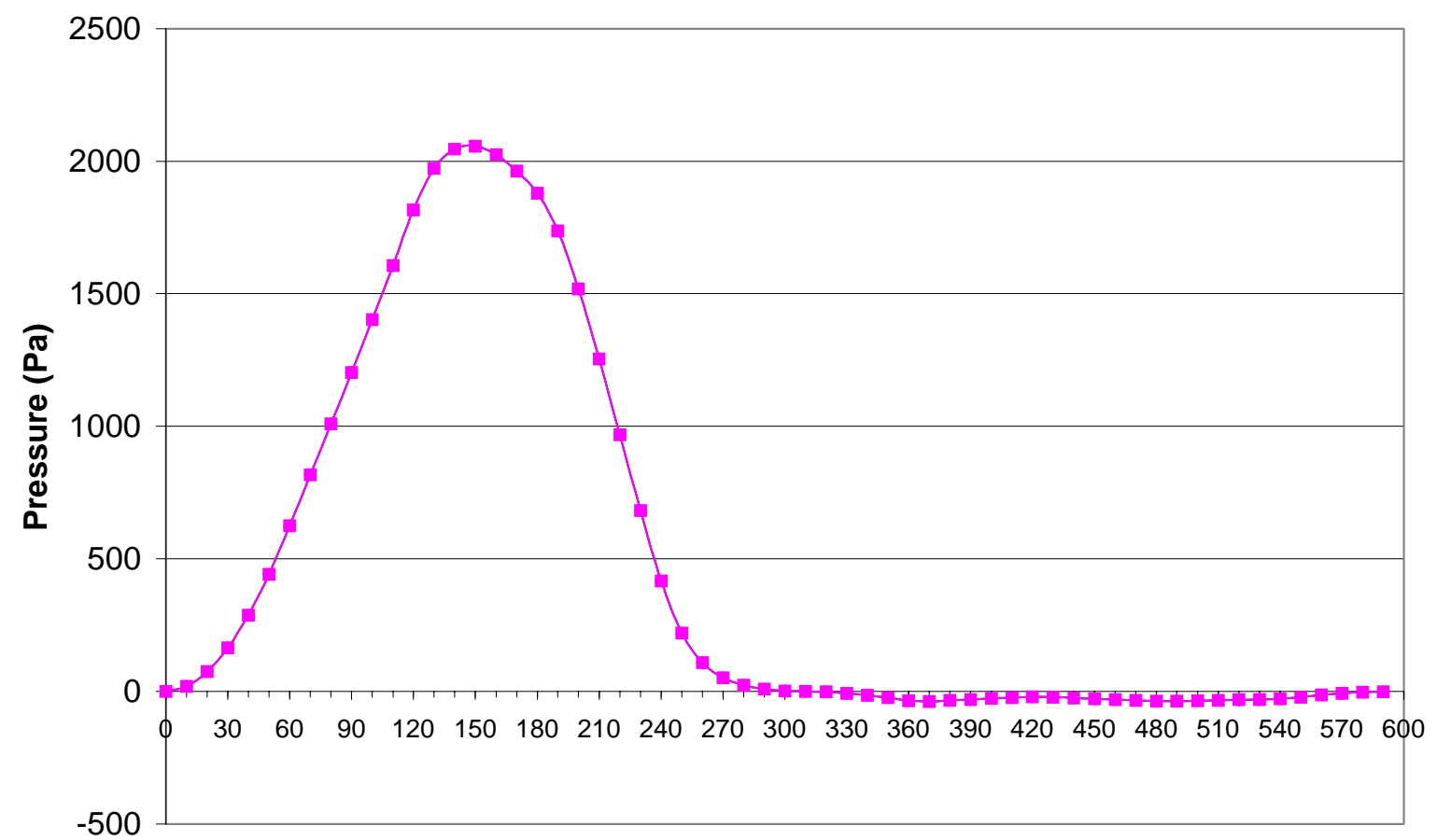

Time (s)

$\rightarrow$ Pressure (1) $\rightarrow$ CTFI Pressure (1)

Figure 1 - Pressure Comparison

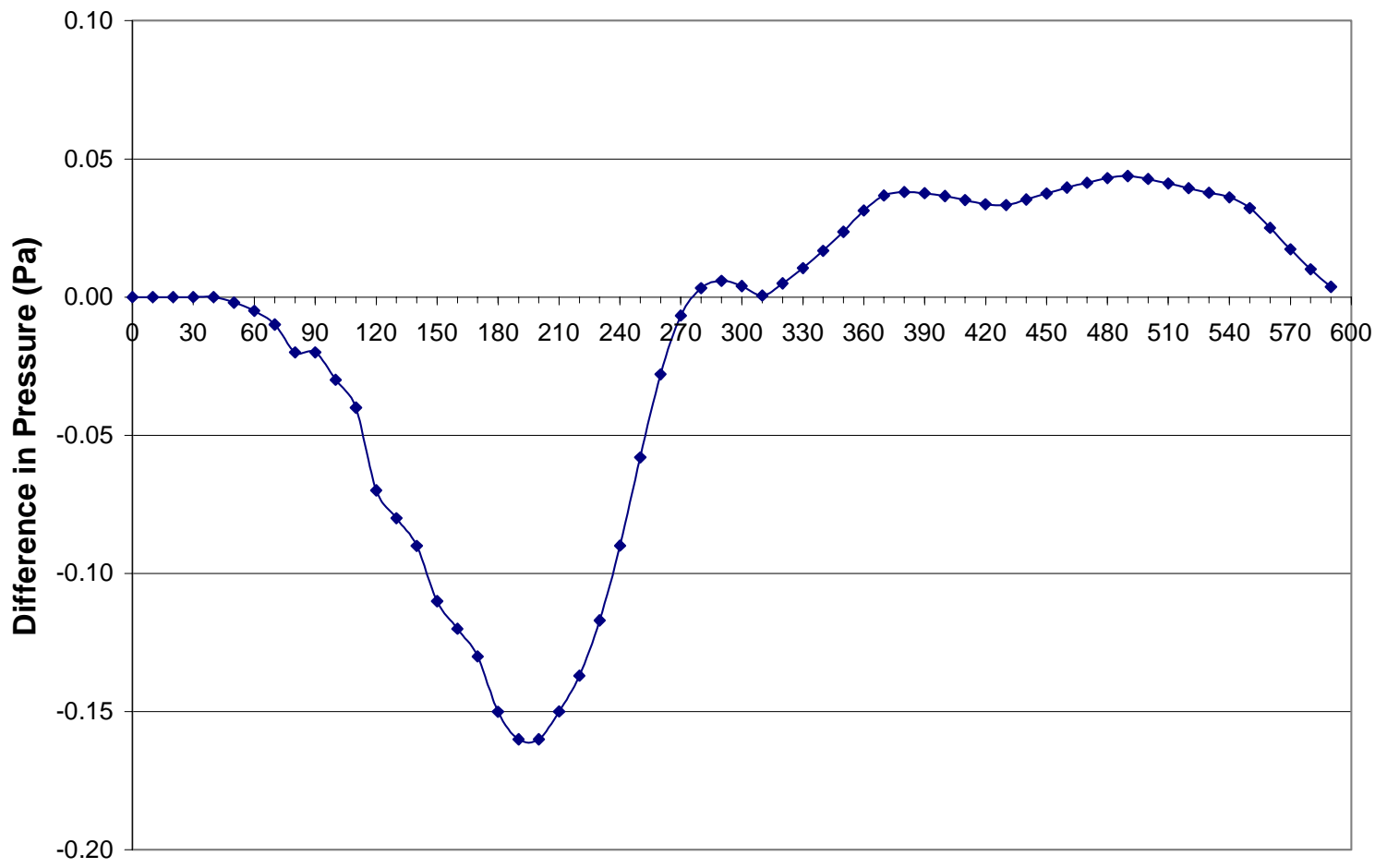

Time (s)

Figure 2 - Pressure Delta 


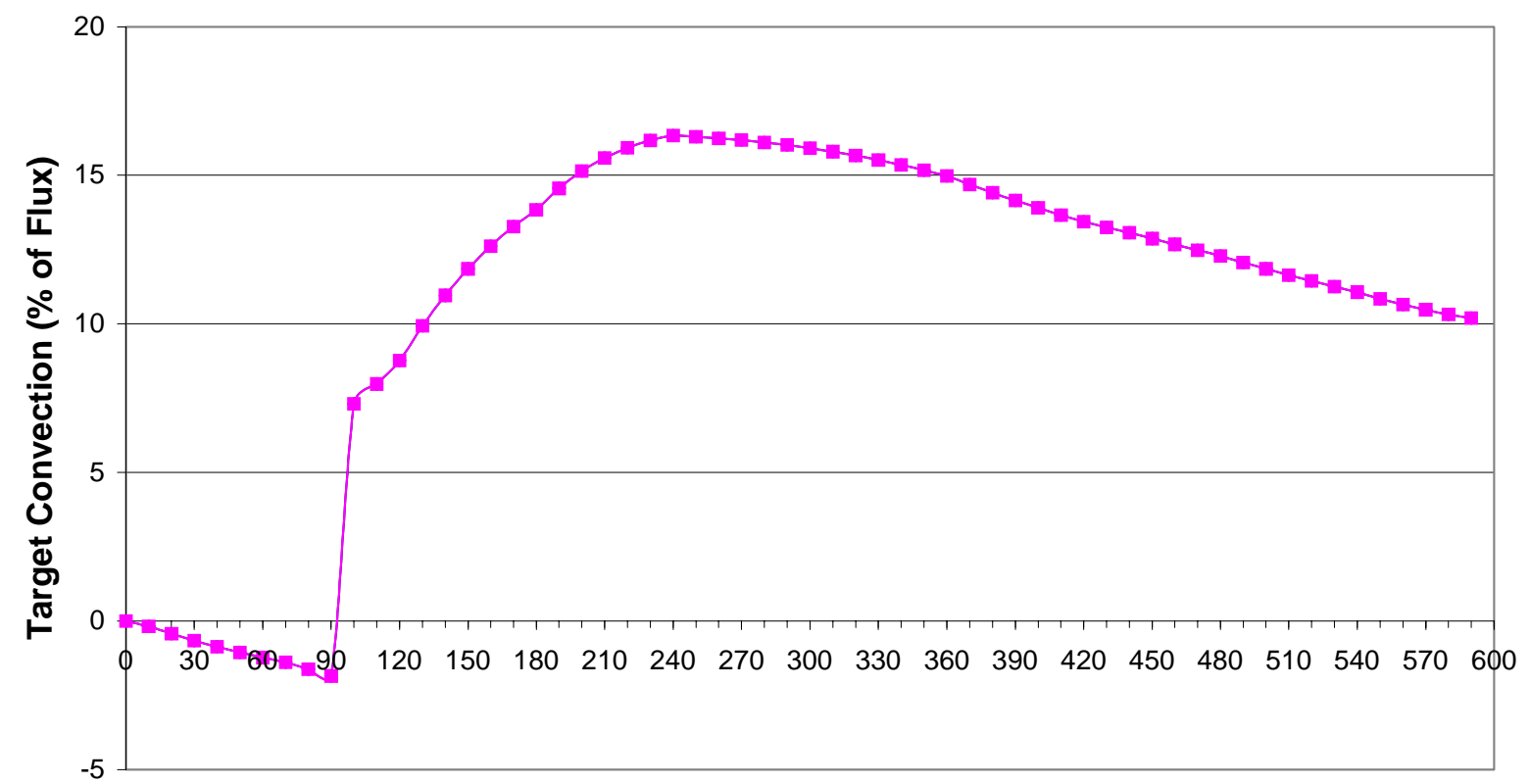

Time (s)

$\rightarrow-$ Target Convec. (1) $\rightarrow-$ CTFI Target Convec. (1)

Figure 3 - Target Convection Comparison

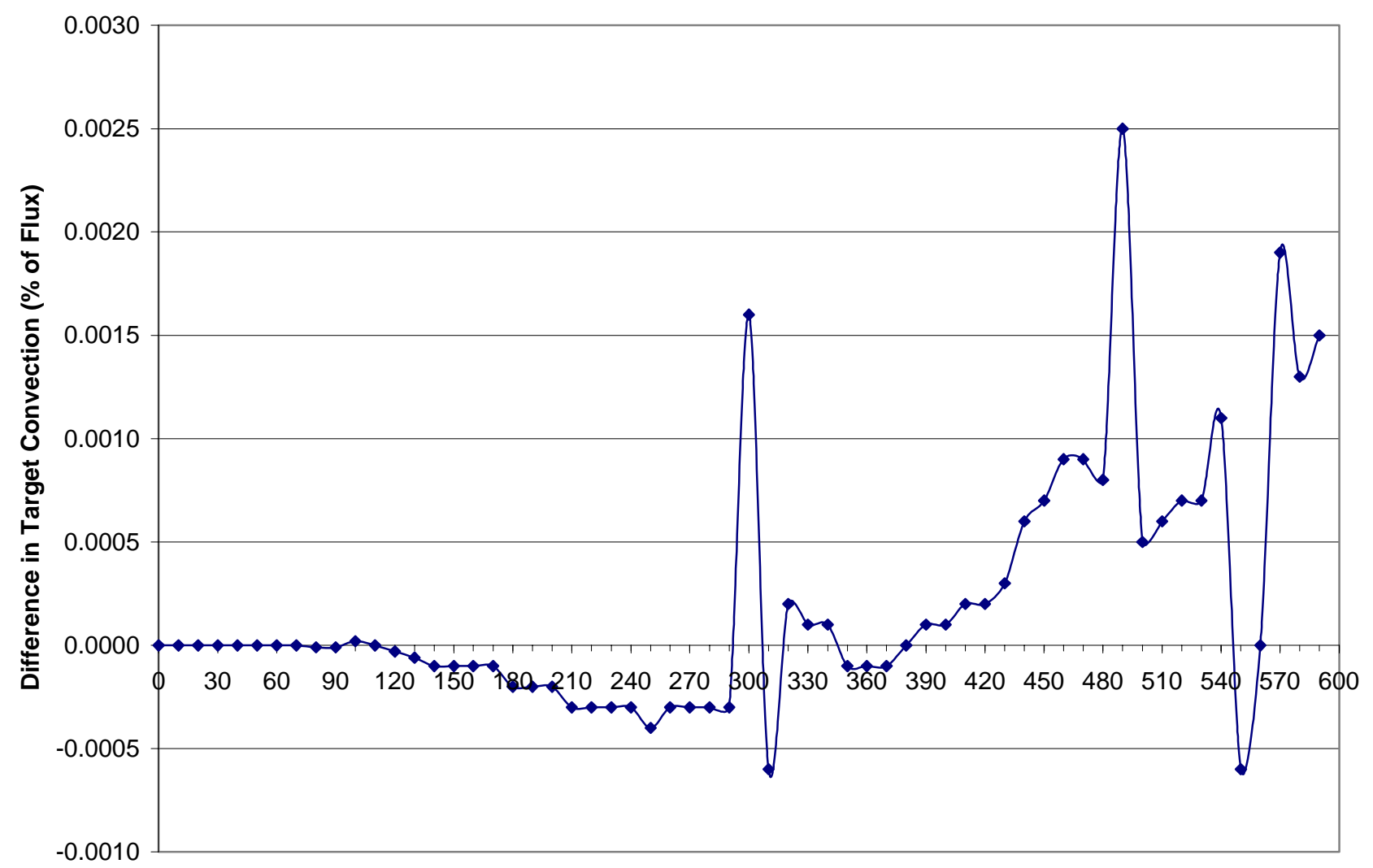

Time (s)

Figure 4 - Target Convection Delta 

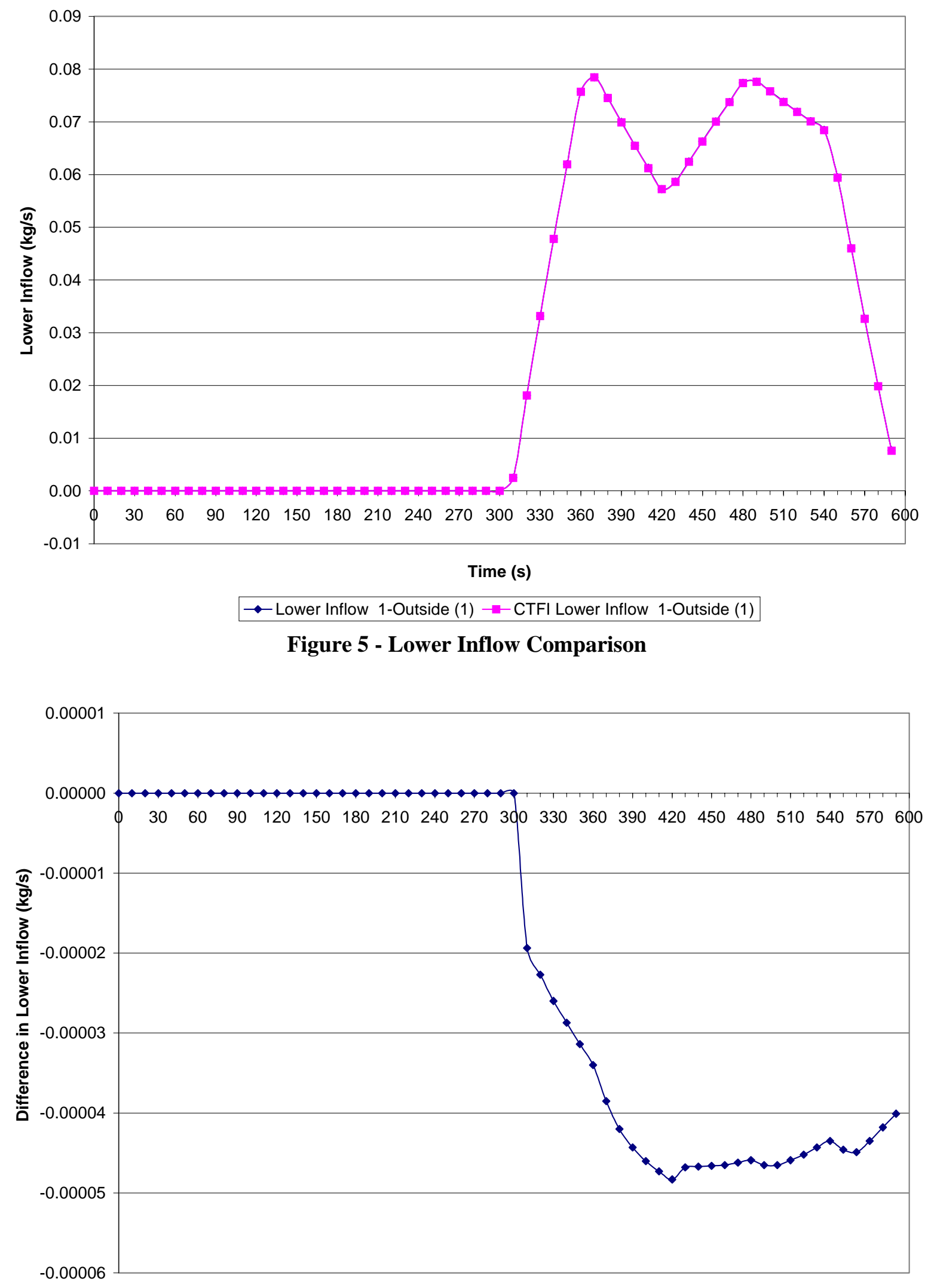

Time (s)

Figure 6 - Lower Inflow Delta 


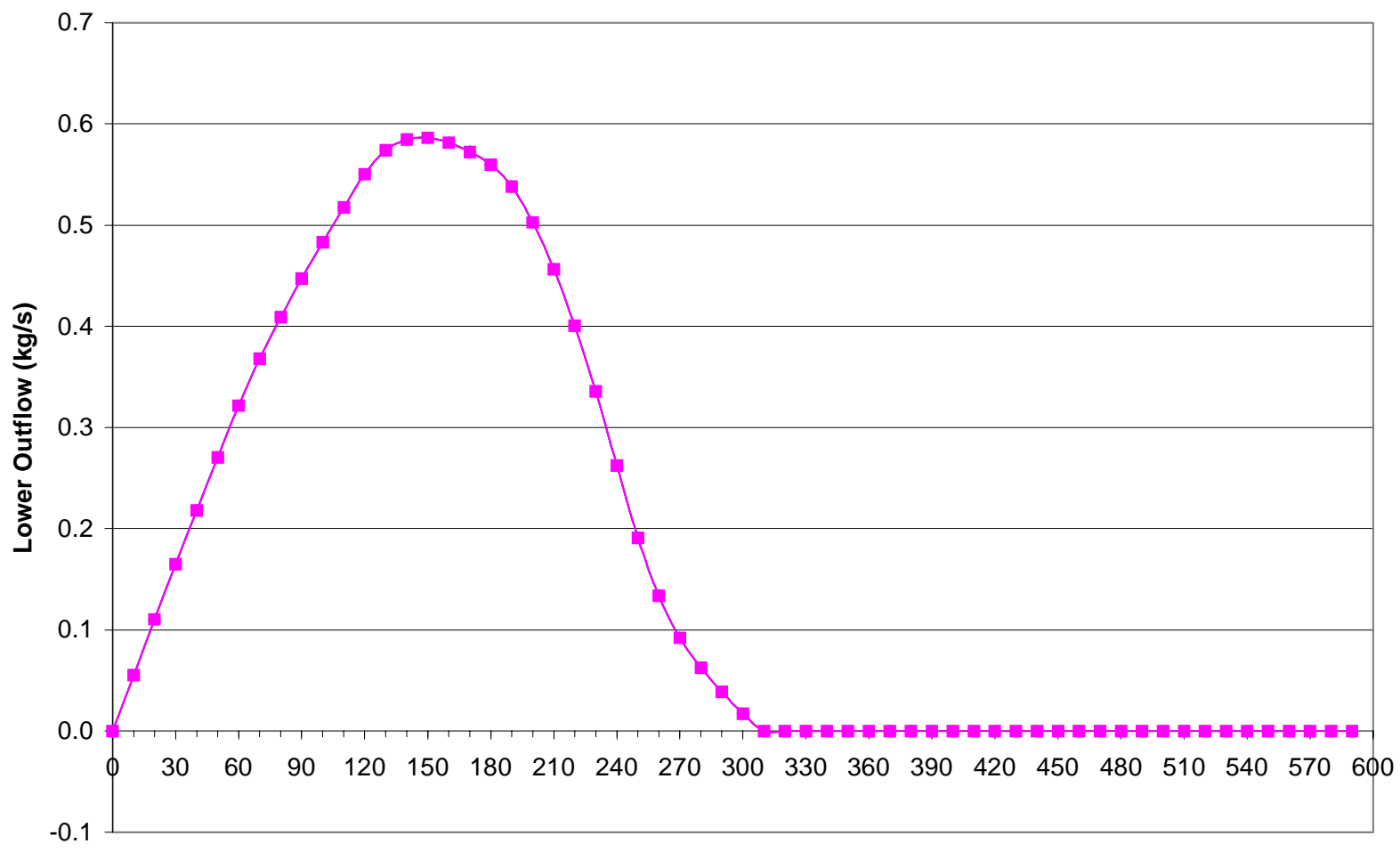

Time (s)

$\rightarrow-$ Lower Outflow 1-Outside (1) $\rightarrow$-CTFI Lower Outflow 1-Outside (1)

Figure 7 - Lower Outflow Comparison

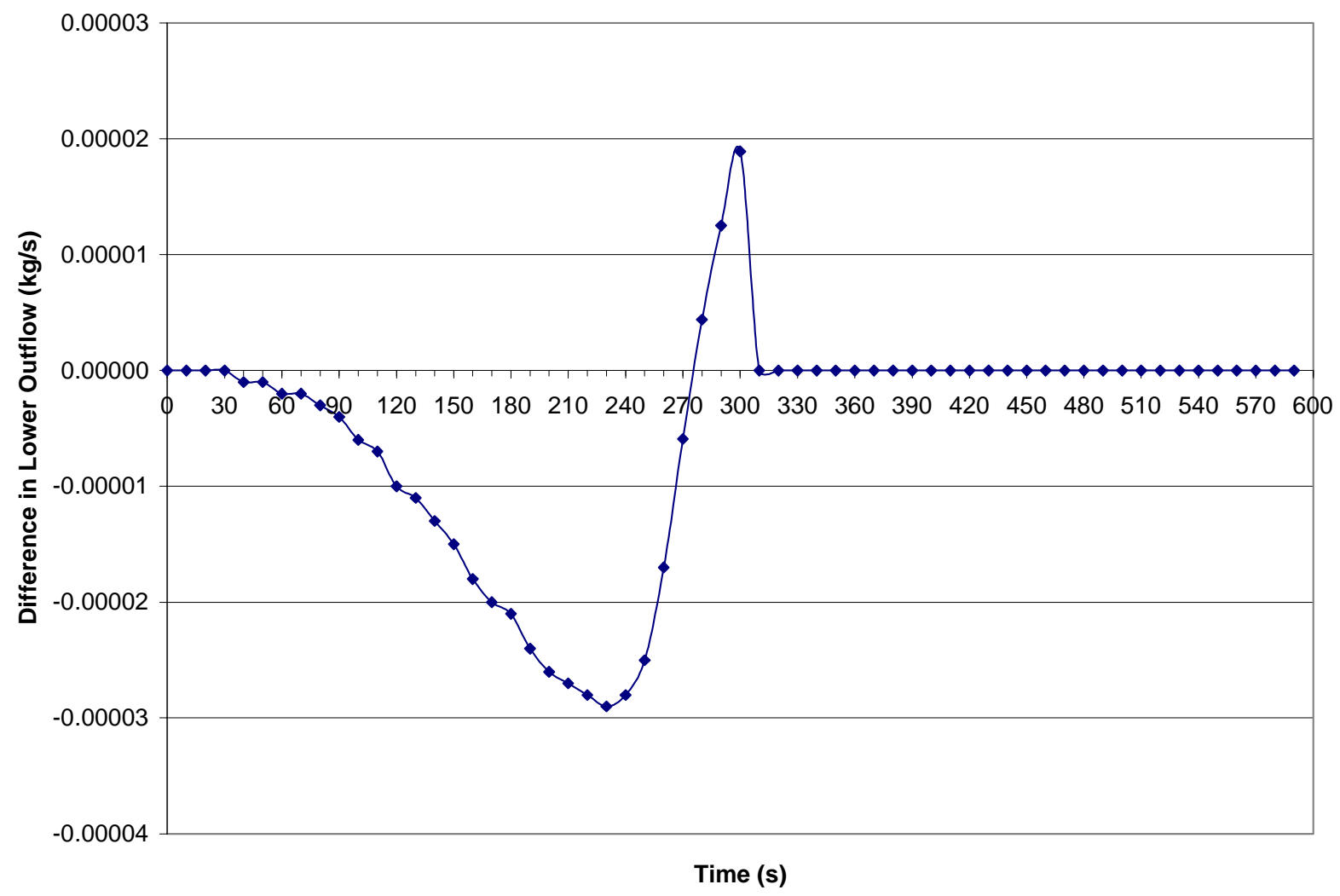

Figure 8 - Lower Outflow Delta 